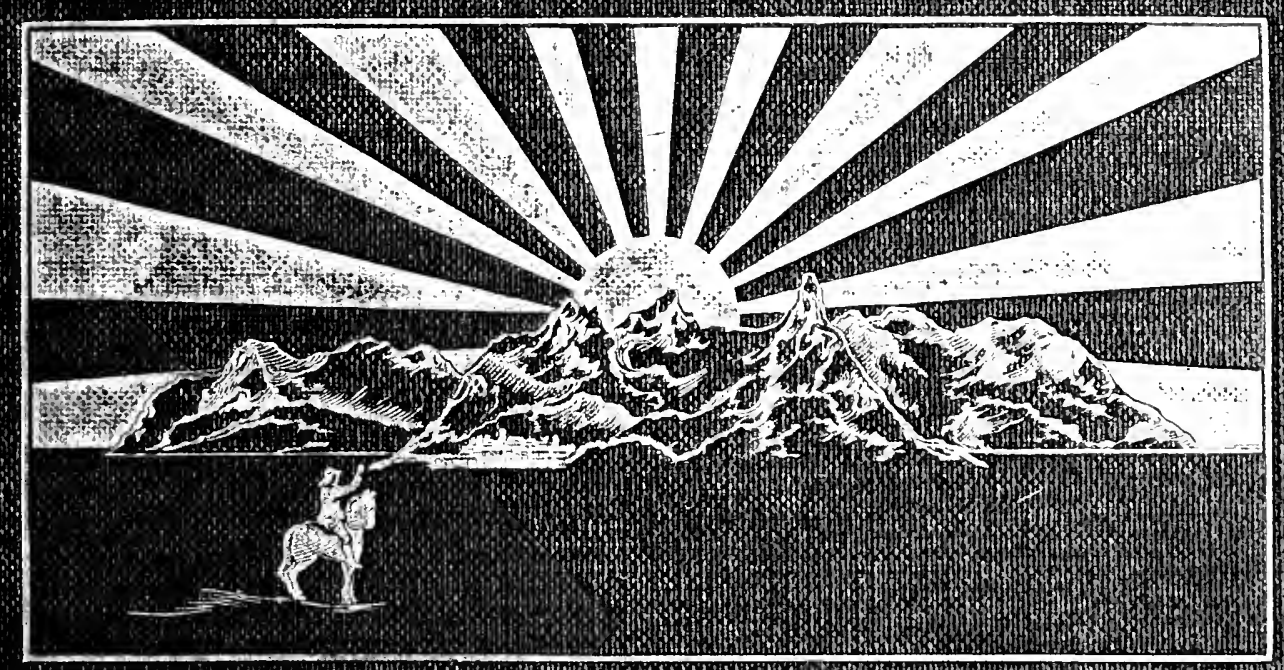



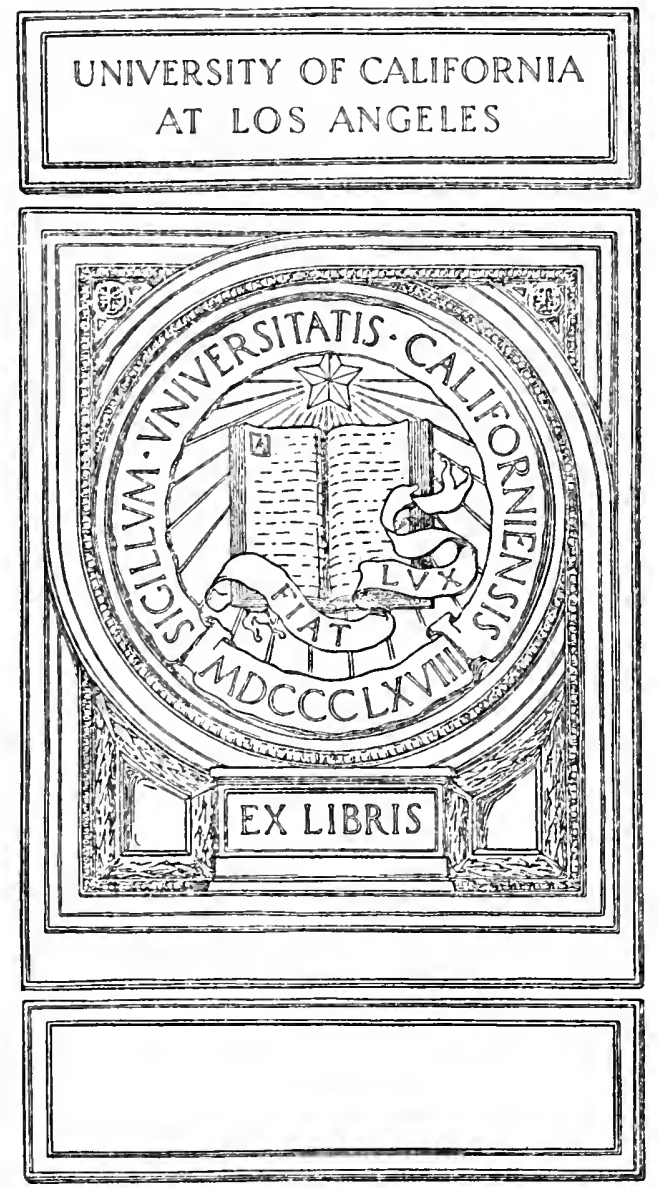


BOYD ALEXANDER'S LAST JOURNEY 




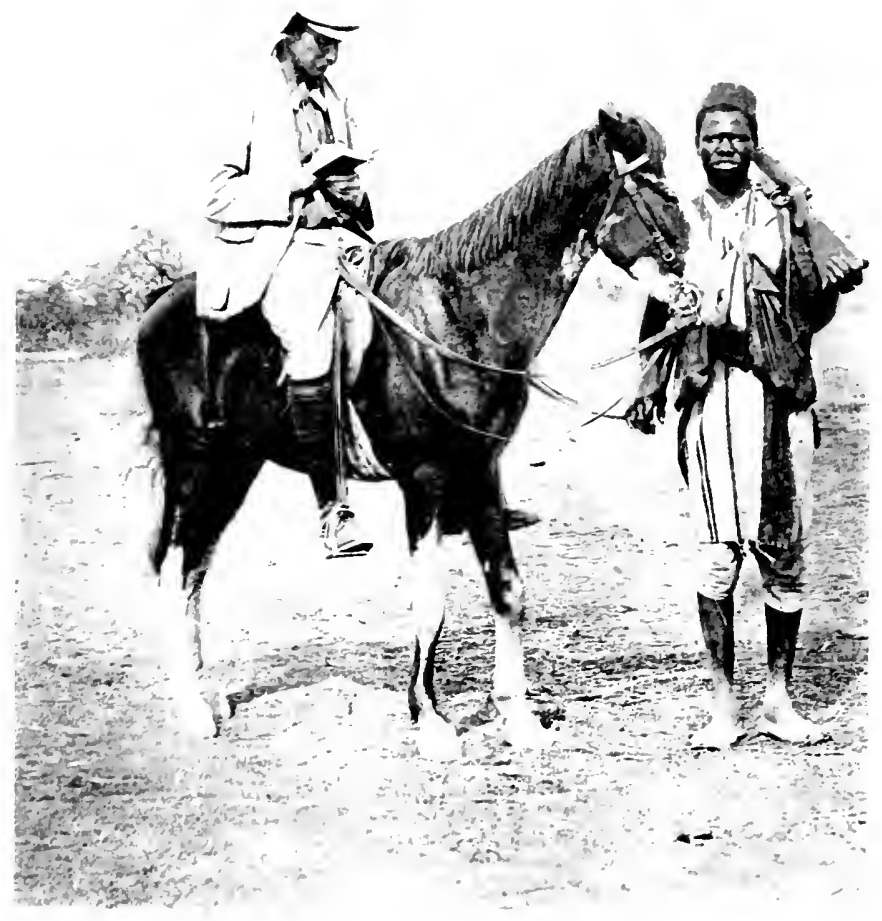

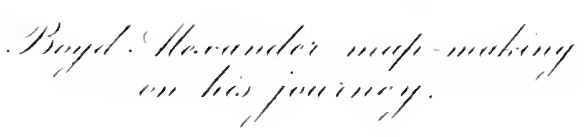




\title{
BOYD ALEXANDER'S LAST JOURNEY
}

\author{
WITH A MEMOIR
}

BY

HERBERT ALEXANDER

ILLUSTRATED

NEW YORK

LONGMANS, GREEN \& CO. LONDON: EDWARD ARNOLD 1912

(All righls riscrial.) 


\section{DEDICATION}

\section{TO THE MEN AND WONEN, NET AND UNMET, WHOSE DEEDS OF DEVOTION FOR MY BROTHER JOIN THEM IN HERO-}

FELLOWSHIP WITH HIM FOR EVER. 


\section{D $T$}

\section{CONTENTS}

\section{MEMOIR}

CHAPTER

PAGE

I. CHILDHOOD

3

II. HIS EARLIER EXPEDITIONS $\quad$ - . $\quad 21$

III. THE ALEXANDER-GOSLING EXPEDITION FROM THE NIGER TO THE NILE . . . . . . 32

IV. HIS LAST JOURNEY AND DEATH . . . 43

INTRODUCTION TO THE DIARY . . . . 57

BOYD ALEXANDER'S DIARY . . . . $\quad$. 61

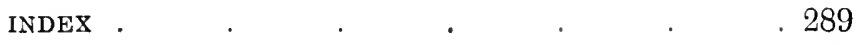




\section{LIST OF ILLUSTRATIONS}

BOYD ALEXANDER MAP-MAKING ON HIS JOURNEY - Frontispiece

"SIVIFT'S," BOYD ALEXANDER'S BIRTHPLACE AND HOME • 6 BOXd ALEXANDER AT ABOUT THE AGE OF TEN YEARS . 12 BOYD ALEXANDER AND HIS NIECE, URSULA DAVIS, STANDING BY ONE OF THE STEEL BOATS USED IN HIS NIGER TO NILE EXPEDITION . . . . . . 12 BOYd ALEXANDER AT THE AGE OF 29, IN 1902 . 30 CAMP NEAR CORFE CASTLE, WHERE "FROM THE NIGER TO THE NILE" WAS WRITTEN . . . . . . 42 THE Clay ORIgiNal (UNFINished) OF THE MARBLE MEMORIAL BY PROFESSOR COLTON, A.R.A., WHICH IS TO BE PLACED IN CRANBROOK CHURCH . . 54 FALLS OF THE LOBÉ RIVER INTO THE SEA NEAR IRRIBI . 74 THE MOUNTAIN, SAN THOMÉ . . . . 76 THE INTERIOR OF SAN THOMÉ . . . . . 76 CAMP ABOVE BUEA . $\quad . \quad . \quad . \quad . \quad . \quad . \quad .100$ THE "BOys" OF the EXPEDition . . . . . 100 THE CRATER IN ERUPTION . . . . . . . . 118 THE CRATER AFter ERUPtion, SHOWING THE LAVA STREAM 118 TOIVARd THE MANENGUBA RANGE . . . . 122 
ONE OF the CRATER LAKES NEAR POALA . . 122

Wonen Dancing at Dalliwa . . . . . . 166

WITCH-DOCTOR PERFORMING “JU-JU" OVER A MAD

WOMAN AT PELLA . . . . . . . . 166

ONE OF CAPTAIN BROCELEBANK's OX Wagons . . 180

a goatherd and his charge in a village cattle

ENCLOSURE . . . . . . . . . 180

THE Festival of SALLA at Yelua . . . . 192

MOUNTED SOLDIER OF DIKOA, WEARING CHAIN ARMOUR . 196

KAEAMI, KACHELLA OF KONDUGA . . . . . . 196

“béhagle's monument." (José standing Beside it) . 202

RABEH'S PALACE $\quad . \quad$. $\quad . \quad$. . . . . 202

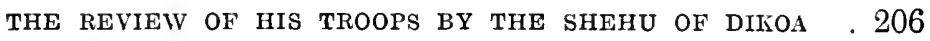

SANDA, SHEHU OF DIKOA .

YAMERA, THE QUEEN MOTHER, WITH HER GRAND-

DAUGHTER, YAASHI. . . . . . 210

a travelling aALlai, Met on the RoAd to ABEchir . 266

A VIEW OF ABECHIR $\quad . \quad$.

THE EXPEDITION MET BY A CHIEF WITH AN ESCORT FROM

THE SULTAN OF ABECHIR . . . . . 270

ASSIL, SULTAN OF ABECHIR $\quad . \quad$. . . . . . 276

the sultan's palace . . . . . . . . . 276

\section{MAPS}

MAP OF THE HAMIERUN PEAK . . . page 56

MAP SHOWING BOYD ALEXANDER'S ROUTE . . At end 
Acknowledgments are due to the editor of The Ibis and Mr. Ogilvie Grant for the use of certain notes which appeared in a memoir of my brother by Mr. Ogilvie Grant in the number of that journal for October, 1910. 


\section{MEMOIR}

By HERBERT ALEXANDER 
"But the dews of heaven passing over ale, do not ever leave the graves unviselee"

$$
\begin{aligned}
& \text { Boyd Alexander } \\
& \text { flavertox. } \\
& \text { hovember.907. }
\end{aligned}
$$




\title{
CHAPTER I
}

\author{
CHILDHOOD
}

TN his Life of Alexander the Great Plutarch asks for 1 indulgence because he does not give the actions in full detail and with a scrupulous exactness, but rather in a short summary, since, says he, "We are not writing histories, but lives" ; and he goes on to point out how a man's character may often be discerned in an action of small note, a short saying or jest, rather than in the greatest sieges or most important battle. Therefore, he says, as painters in their portraits labour the likeness in the face, and particularly about the eyes, in which the peculiar turn of mind most appears, and run over the rest with a more careless hand, so we must be permitted to strike off the features of the soul in order to give a true likeness and leave to others the details of the achievements.

When so great a biographer as Plutarch lays down this maxim, I think I need hardly ask forgiveness if in the memoir of my brother I follow his example and pay more attention to recalling my impressions of the intimate things of the character and soul which the close tie of brotherhood is able to reveal and only indicate in outline the history of his deeds and work, trusting that they of their excellence stand firm enough to make his monu. 
ment, to which I now bring with a loving hand, as it were, a wreath of recollections.

Besides, not having any practical knowledge of any one of my brother's callings, either as explorer, soldier, or ornithologist, it were a hopeless task for me to try to do him justice in respect of these. But for many years of our early life we grew up together, when, if only memory will serve, so many of the qualities can be found in the child that went to the making of the man. And then again, for more than a year after his great journey across Africa, when he returned to find himself famous, I was engaged in helping him in the writing of his book and travelling with him to the various towns where he lectured, which meant that we were together throughout that time all day long and under conditions exceptionally favourable for the study of character and capacity. But for this opportunity it would have been indeed difficult to give more than a shadowy sketch; for from the very nature of his calling the explorer's life, as it is expressed by contact with his fellow-men, must be so little known. The writer, painter, scholar, even the soldier, is surrounded by his family and his circle of friends, who have had talk with him and have known him intimately for many years and shared with him the hours of work and play. But the true explorer, the pioneer, must live so much of his life alone, and, even if at times he has companions, the conditions of work are such as are likely to keep them far apart throughout the day. So the best years of youth go by, when friendships are made and love is won, and though he returns to his own country from time to time, it is only too often to find that some of those that were dear to him are dead.

It has become difficult for him, even in the happiest circumstances, to pick up the threads of all the little 
things which mean so much in the crowded social life. The small-change of conversation, so to speak, has got rusty in the purse for lack of use. For a time he makes an effort and is gay with the rest of them, but the fret and strain to overcome the shyness that has overtaken him are too great and his thoughts go back to the peacefulness of the big things that lie beyond. Then suddenly he realises that all the time among people he was " girt with a thirsty solitude of soul," and then his heart leaps up and beckons him to follow again the lonely trail, where Life will give a clearer echo to his call among the rocks. And it is for this reason that we find explorers seem so remote from us. Their achievements are known, but so little of the men themselves belongs to us. This loneliness of spirit, for me, was the most tragic thing in my brother's life. Sometimes he used to say to me, "It must be so nice to have so many friends; how I envy you! I have been away so long that I have outgrown mine; people are very kind to me and $I$ am very fond of them, but there is no one to whose life I am necessary or who is necessary to mine. I suppose it is too late to hope for that sort of friend now, and I shall always feel alone."

Boyd was my eldest brother. Our father, Lieut.Colonel Boyd Francis Alexander, came to live at Swift's Place, Cranbrook, which is situated in the most beautiful part of Kent, on retiring from the Army about forty years ago. He comes of a Scottish family, whose home was at Ballochmyle in Ayrshire, a property which is still in the possession of the elder branch of the family, whose head to-day is Sir Claud Alexander.

Burns was a ploughman living in the little cottage of Mossgiel upon this estate when my great-great-uncle was the owner in 1783, and it was to his sister, Wilhelmina, 
that the poet, who saw her one day walking in the grounds of Ballochmyle, addressed his lovely poem called "The Lass of Ballochmyle."

If I were to go no further back than one generation to find a source from which to trace Boyd's quality of pluck I would recall my father's services in the Indian Mutiny. $\mathrm{He}$ was twenty-three years old at the time he led the storming party at Fort Birwah up the scaling-ladder and was twice wounded, by an arrow in the shoulder and a bullet in the neck.

It is often said that all men who have reached fame have had great mothers. Boyd's was the most devoted mother that ever lived, a woman of tireless energy, and the bravest of the brave. I have heard a workman say of her that she did the work of three men. Early in her married life she was called upon to show her courage. It was in the Irish-American Rebellion, when my parents were living in a wooden house outside Ottawa. Often my father would be called away on service, and my mother, left all alone with her little baby-girl, would cheerfully defend the house against any ruffians that might come to molest her; indeed, the servants had bolted, so great was the public terror. One night two men did come and demand an entrance, whereupon my mother opened the door and challenged them, and when they made no reply but tried to get past her she fired with her little silver pistol at their legs, so that they ran away.

I will give one other story of my mother, because Boyd was with her on this occasion, which must have been his first adventure. He was only eight years old at the time. My mother was taking him with her to the Isle of Wight, whither she was hurrying to see one of the other children, who was ill. There was a dense fog in the Channel and 


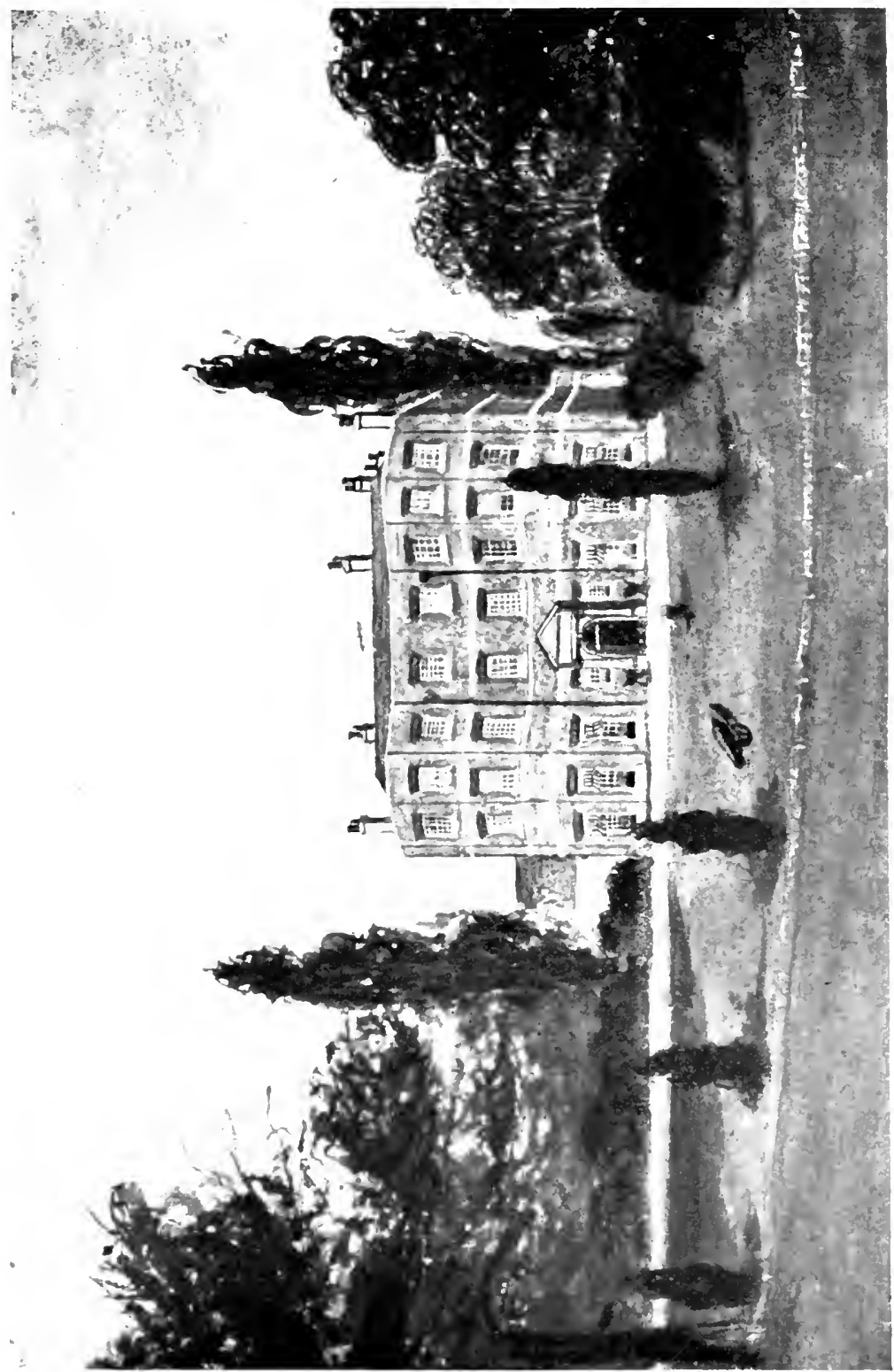



a choppy sea, so that the steamers were not running. My mother, therefore, hired a little rowing boat to make the passage, paying a heavy price for it as it was difficult to find a boatman willing to take so great a risk. Even then not one would go unless a male passenger accompanied her. So my mother canvassed all the passengers, and at last one consented, but he added to her anxiety all the way over by giving vent to regrets and reproaches in the most spiritless manner.

If we look for ancestral types from which to trace Boyd's taste for adventure, we find them on both the paternal and maternal sides. On the former in the person of our great-great-grandfather, Claud Alexander, who restored the family fortunes by his enterprise in India. $\mathrm{He}$ was an administrator in the East India Company in the stirring times of Warren Hastings, and there is still preserved at home a letter from his brother Boyd, and addressed to their sister, the lass of Burns's poem, saying, "The Governor [Warren Hastings] does nothing without first consulting Claud."

On the maternal side our grandfather, David Wilson, was a most remarkable man. A friend of Burton, the great explorer, he himself might be called a merchant pioneer. At sixteen years of age he was not content to accept a comfortable post and salary offered him in a business at home; but, impelled by the love of an adventurous life, he went out to India "on his own." Gifted with extraordinary energy and courage, he soon became a man of mark in the trade world of the East, and made, and lost in a bank smash, and made again a large fortune before he was forty. It was out of his enterprise that the fair hill-station of Darjeeling rose.

Boyd was the elder of twin boys born on the 16th of January, 1873. As it was doubtful if the younger, Robert, 
would survive the early hours of infancy, the vicar was summoned hastily to christen the children, and the ceremony was performed in an old silver sugar-basin which is a family heirloom. The fears of the doctor, however, were fortunately not fulfilled, so the twins grew up together through childhood and school-days, and their ways did not part till at twenty years of age they entered different battalions of the Rifle Brigade Militia.

My earliest memory of Boyd in our nursery days dates from the year when he was six and I four years old. On a cold winter's day of deep snow we three older boys had gone out with the nursemaid for our morning walk. I think it was the first time in my life that I had come in actual touch with snow, and as I played with it and made snowballs my excitement was so great that I did not notice how cold my hands had got till the game was over, and then the cold suddenly gnawed my bones with excruciating pain. I had no gloves, and ran to the nurse sobbing. But I got little sympathy. Then Boyd, seeing my agony, instantly took off his gloves, and running back put them on my hands, although his own were quite as cold. Then for some reason or another I cried the louder, at which the nursemaid called me a donkey, for she could not understand.

From their earliest days right up to the age when their ways parted there was an extraordinary likeness between the twin brothers. Of this they were very proud, and the common possession was often worked by them to their mutual advantage. At school they were made to wear different collars, so that the masters could tell them apart; but on occasion when one, under sentence for some crime, wanted his freedom for a special purpose, the other by changing his collar would take the punishment for his brother, undiscovered by the master. Even 
earlier in their lives than this, when they were in the nursery, they had learnt to take advantage of their circumstances. One, I forget which, did not mind the medicine that the other detested, so he cheerfully, and probably for a consideration, swallowed the daily doses of both. After all, it would have shown a lack of resourcefulness had the children not extracted a useful working principle from the unconscious mistakes that their elders were constantly making. An old friend of our boyhood, John Springett, bootmaker and taxidermist of Cranbrook, who in after years had many bird-hunting adventures with Boyd, was telling me the other day of a case in point. He had come one day to measure the twins, who were four years old at the time, for boots, and having finished with the younger boy, Robin, was lifting Bee (as Boyd was called) up on to the big oak chest, when the nurse accused the latter of being his brother come back again. Whereupon the little fellow exclaimed, "No, I am Bee, and always will be."

As children the twins were remarkably shy. I do not think that I myself had this failing by nature, but the habit was soon imitated from my elder brothers, as a matter of good form. I should say that Boyd kept this characteristic to the end of his life, probably because he spent so much time alone in the wilds, and found that his returns to the restless conditions of civilised society made him feel ill at ease.

Sometimes their shyness would lead the twins into odd situations. A sight of a visitor approaching the house, or the scrunch of carriage wheels upon the gravel, were signals for an immediate stampede to cover. Remembering one of the occasions recalls to my mind old Thomas Webster, the Academician, who always seemed to us boys a romantic but somewhat awe-inspiring figure, with his 
round, rubicund face and long white hair, velvet coat, and huge wide-awake; driving himself about in a bath-chair drawn by a ridiculous donkey with a long and beautifully abundant tail, which was false and came off with the harness. One morning the dear old gentleman came to call upon my mother to give his opinion upon a picture which had just come home. The twins were up to some mischief in the dining-room as he came in and scampered at once into hiding under the table. After examining for some little time the picture he had come to see he happened to turn round, and his eye fell on a portrait group of the boys which was hanging at the other end of the room, whereupon he exclaimed in lively tones, "Why, there are the boys!" Picture his astonishment when the twins, imagining they had been discovered, crawled out from under the table, and stood before him, their faces crimson with shame!

But I fear that the respect which my brothers entertained for the master was not extended to his "moke." It was a frequent kindness on the part of the distinguished artist to come and spend an hour helping my sister with her painting. During this time the donkey was supposed to be resting, tied up under the shade of a tree; but if the truth had come out, he was, as often as not, doing nothing of the sort, having fallen a victim to the designs of the naughty boys, who, one with reins and other with whip, urged the wretched beast at a pace far exceeding his habit a cross-country course over the park.

At the best of times Boyd was slow of speech and appeared to find it rather difficult to express himself on the spur of the moment, and I observed that for several months after the long time he spent alone on his transAfrican journey these disabilities were much more marked. 
To any one who understood him and could see beneath the surface, at a public dinner or large social function he was a pathetic sight. He seemed dazed by the ordered confusion, and on a great occasion when he had to make an after-dinner speech (and did it remarkably well, by the by) he once said to me as we went home, "Isn't it strange to think that all that was done for me? I don't know what I ate, and I didn't dare drink anything because of the speech, and what the chairman said to me or I said to him during dinner I haven't a notion, for I felt quite sick with dread. He must have thought me a very dull dog." Of course I told Boyd that his speech was splendid, and then I suggested that he must be hungry as he had not eaten any dinner-and what about our popping in to the "Troc" for a little supper to ourselves? Then, acting on my suggestion, he soon made up for lost opportunities, and over our meal became as happy as a schoolboy and as bright as a button. Afterwards when the lights and our laughter had been turned out, and we were driving home, he remarked on my silence and said he was afraid he had tired me, to which I replied that I was only thinking how I wished we could have invited the old chairman to supper with us.

I do not think that "de mortuis nil nisi bonum" is a proverb that was ever intended to apply to speaking of the sins of boyhood, so I will tell the following story, which concerns Boyd most gravely perhaps as the eldest and therefore the ringleader of the trio.

Looking back to the time before our school-days, when Boyd and Robin were about nine years old, it is difficult to find trace in any one of us of the moral sense. This sounds shocking, but I am sure we were not really wicked. We had merely not developed our ultimate capacities, that was all. Indeed, I am inclined to think 
that it was rather a healthy condition than otherwise, for with our constitutions unweakened by over-growing in the moral direction Nature could pay her attention to developing other qualities, such as enterprise and daring, that are apt to be arrested if all her energy is expended in nurturing such a delicate growth as the moral sense. Let us hope that, left to the last, this had all the richer soil to root in!

And now for the confession. We three boys conceived the idea of a new game, which consisted in going into business in the stationery and fancy goods line. Under the sign of "Pumplin \& Co." we opened premises on the top landing of our London house. All our pocketmoney and savings were put into the concern for buying our stock-in-trade, while customers were drawn from our parents and their friends and also from the household. We were, besides, made stationers "by appointment" to the schoolroom. I think that our parents and the governess encouraged the enterprise, believing it to be an excellent aid to teaching us neatness, arithmetic, and the value of money. As a matter of fact it did nothing of the sort, except the last, perhaps, for we quickly developed a very swollen idea of the value of other people's money, and became perfect little Shylocks, so that our greed, alas! brought us down even so low as the committing of crimes. We did a large amount of business with the servants, and if unfortunate new footmen or maids did not give us what we considered sufficient custom their lives were soon made so wretched by our bullying and blackmail that it was practically a question with them of parting with their money or their situation. Conducted on these lines our business throve, but soon we were not content with profits at the rate of about four shillings in the pound, but plunged deeper into crime. 


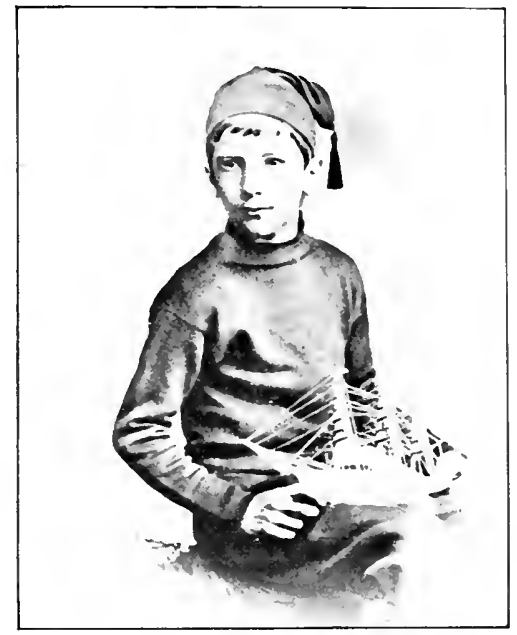

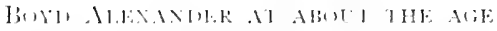
DF THX YEIRS.

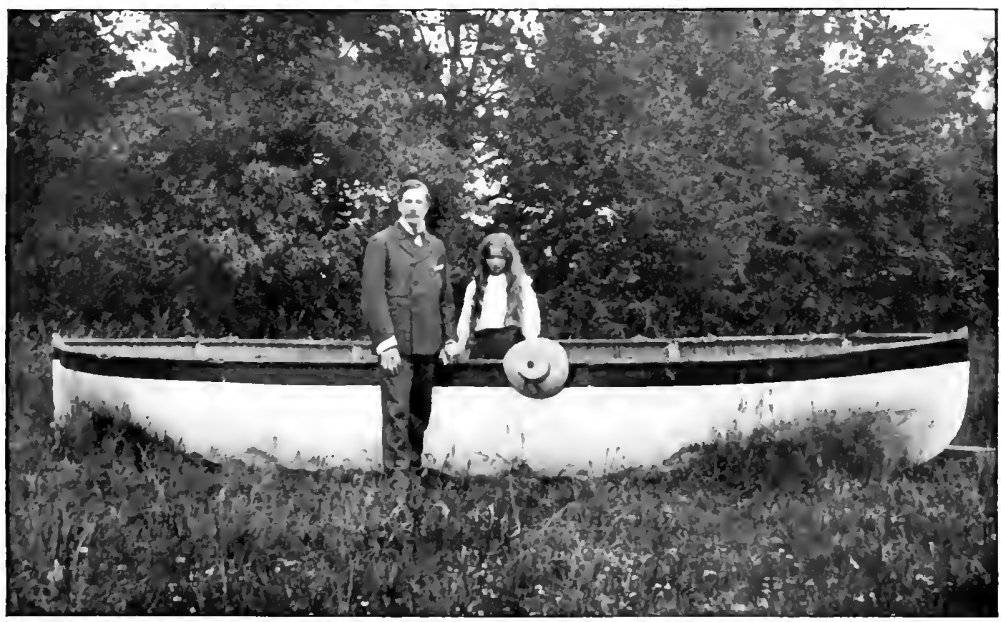

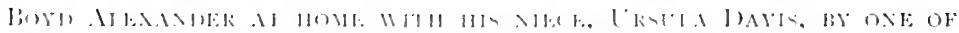

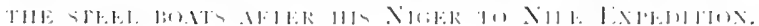



When it was necessary to lay in a new stock of goods we used to go with the nursemaid to a large shop in the Edgware Road or to the Baker Street Bazaar, and while one boy took his turn in the outlay of a few pennies upon a purchase, which was purposely made very difficult so as to require the utmost attention of the shop assistant and the best advice of the maid, the other two would roam round pillaging the trays along the stalls and dexterously transferring various things into the sailor "tops" which we wore in those days, a style of dress well suited to our wicked purpose. These evil practices continued for some time, and eventually were the cause of the winding up of our business; not, as no doubt the reader guesses, because they were discovered, but because we found it was easier to increase our armies of tin soldiers, which were our most absorbing interest in those days, directly by employing these dishonest methods than by waiting for our business profits wherewith to buy them.

Many years after Boyd and I were recalling these naughty deeds, with laughter I am afraid, and we agreed that we did not think it likely we would ever be moved to send conscience money to the Chancellor of the Exchequer; and that it might seem strange, but somehow or other we could not feel that our old sins belonged to us at all, and we wondered whether it was because we had renewed our whole beings three times in the thrice seven years that had passed since those days. Curiously enough, we would not have dreamed of touching money. Looking back now upon these and many other like escapades of our childhood in London, I cannot help thinking that they grew out of our intense hatred of a town life; for in the country, though we were mischievous, the things we did were comparatively harmless. 
At about ten years of age Boyd and Robin went to school, and no doubt it was none too soon! Up to this age we three boys had been taught almost entirely by our father, but I fear it was not till some years after, when we had reached a more reflective age, that we realised how grateful we should be to him for the patience and pains which he expended in breaking up and cultivating the stony ground of our very stubborn intellects.

My times with my brothers were now confined to the holidays, and needless to say I looked forward to these with great excitement, for references, provokingly laconic, in their letters home, about birds' nests and egg collecting conjured up in my mind visions of a new and wonderful world that my brothers were going to open for me.

Although I cannot speak of Boyd's school life at this period, I can of his school, for during his second summer term he fell ill and came home for a month, and I was sent down to take his place. Thus it happened that I spent one of the happiest times of my life. The school, which was quite a small one-I think there were not more than twenty boys there at this time-was kept by Mr. Somervell, as kind a master as one could ever meet, and immensely popular with all. The school-house was an old manor, called Hazeley, surrounded by a delightful garden from which a fine avenue of old elms led to the cricket-ground that looked upon some of the prettiest country to be found in Oxfordshire. Rooks and jackdaws, cawing in their nests in the avenue by day, and owls, hooting round the ivied chimneys at night, seemed the guardians of an ancient peace that brooded in this lovely solitude off the highway of Time. Surely it must have been here that the little boy, who was much quieter than his fellows and slower at games and nearly always absentminded, first felt the magic touch of Nature, and heard 
the call of the birds that led him in after days over the seas, sometimes to pleasant places, sometimes to desert wastes, on journeys as far as the swallow wings, never resting from the quest till the day when he heard in the air above him the beating of the Giant Wings.

After a year and a half at Hazeley, the twins were moved to a larger school, on the South Coast, to which I accompanied them. This was not a very happy time for any of us. We were exempt ourselves from corporal punishment owing to our parents' strong disapproval, but there was for the rest of the boys what in these more gentle days would be thought a far too reckless use of the cane. As might be expected, this harsh system had a brutalising effect on the natures of many of the boys, and bullying in that school was carried to the pitch of a fine art. As I have told you before, the twins were extremely shy, and not being good at their books, were in a lower form than looked fitting for their size; added to this they were extremely modest. Moreover, they were not in the least bit understood, and so they continued to suffer a sort of passive and persistent form of persecution, which generally took the form of ridicule, with a truly Christian patience. Not a boy in the school dared to be actively aggressive, for the brothers looked too dangerous for that, till one day one of the arch bullies of the school went just a step too far with Robin. I fancy I can still hear, as I write, the sounds of the three clean blows that twisted the fellow into a howling knot upon the ground, and I doubt if any one battle in history ever brought about so sudden and complete a revolution in the constitution of a country as did those three blows in our school. It was amusing afterwards to see the "cock of the school" pick Robin out from an obscure position in the tail on the 
Sunday walk along the parade to be his companion in the very front. Though this boy had been a great bully, he was brilliant, and he had a certain amount of genius for leadership, and was popular in spite of his failings. But his power had been shaken; the quiet influence of the twin brothers was now over the school, and a day came when an act of tyranny on the part of their leader was resented by the whole school, who held a parliament and deposed him. Had the brothers been seekers after power, here was their opportunity. But they never nursed any feelings of revenge, and after a little while the picture of the fallen chief sitting apart and very sorrowful aroused the pity of his judges, who forgave him and set him up again. He had learnt his lesson and ruled more wisely, and the lot of the small boys became happy in the school except for the terror of the cane.

It was while I was with Boyd at this school and during the holidays that I observed the growth of his extraordinary keenness for natural history. Perhaps this passion for collecting, this thirst for the excitement of birds-nesting, trapping, and handling the forbidden gun are common more or less to all boys, but Boyd's devotion was more than these and showed itself in his precocious knowledge of such books as White's "Selborne" and "Bewick," in the wonderful neatness and method of the arrangement of his egg collection, and in a systematic diary of the migrations and habits of the birds in the neighbourhood of our home.

At school he was not particularly fond of games, his left-handedness seemed to be a difficulty to him, but, although doubtless he employed many a trick to get off and range the country-side for birds nests, he was by no means unathletic or unmanly, for he represented Radley College in the Public Schools' Boxing Competition the 
same year that his twin brother was her champion for gymnastics.

An incident of Boyd's boyhood is perhaps worth relating as characteristic of the future explorer and ornithologist, in that it shows in the boy those qualities of pluck and devotion to a hobby which were such conspicuous features in the nature of the man. He could not have been more than eleven at the time, when we three brothers had come home for the holidays, and all, wild with the joy of our first day of freedom, were scouring the place in an eager search for nests. Not much luck had attended our efforts, though many risks of broken limbs had been taken, until evidence of a swallow's nest was discovered inside the roof of a disused barn. The door was locked, and how to force an entrance was the problem still occupying the energies of Robin and myself outside, when to our surprise an exulting shout came from Boyd up in the roof, and till this day it is not known how he had effected an entrance. But his triumph was not destined to last long, for, just as he had reached his hand up into the nest to count the eggs, there was a horrible crash among the rafters, briefly followed by a sickening thud upon the ground. Then for a few moments, that to us outside seemed an age, there followed a dead silence, presently broken by moans. Frantically we kicked at the door and tore at the boarding in order to get to his rescue, but with no success; and to add to our horror through a crack in the boards we could see Boyd lying with his head in a pool of blood. Fortunately we sighted a labourer who was working in a neighbouring field, and at length with his help the door was broken open, and poor Boyd was brought out and laid upon a heap of straw. Water was fetched from a well near by, and after a little while he revived. It was then seen that in falling he had struck the 
rafters with his jaw, and that three of his teeth were broken off. It was close on lunch-time and we were about half a mile from home. We urged him to let one of us run back and bring the pony cart, but he would not hear of it, fearing that if his mishap became known to the elders a stop would be put to our independence and all our fun spoilt for the future. So he struggled home in his shaken and crippled state and actually made the attempt to endure his pain through lunch as if nothing had happened. But his dazed condition and battered face at length attracted notice, though not before he had won the day for his brothers and himself, for the serious nature of his accident was never realised by our parents, their chief fear being lest his appearance should be permanently damaged. So this was by no means the last of the adventures we boys had in pursuit of our pet hobby. In after years we often used to chaff Boyd about his accident, telling him that though we ourselves had grown out of the boyish craze of egg collecting he had had it too deeply knocked into his head on that occasion ever to be cured of it.

Side by side with his taste for natural history another excellent boyish characteristic showed in the form of a steadfast hero-worship, the objects of which were never dethroned from his regard, but remained his pattern heroes to the end of his life. These were Napoleon and General Gordon. In viewing the record of Boyd's achievements, so remarkable for so young a man, and one that has placed him among the great explorers of history, and remembering this early hero-worship of his, it is interesting to observe how the "child was father to the man." For this was the inspiration which largely helped him in after years to overcome well nigh unsurmountable difficulties. When alone in the midst of dangers and fighting the leagued forces that fate arrayed against him, of savage men and 
the no less fearful foes of fever, famine, and flood, like the fighters of old, he carried his gods into the battle, and many must have been the times when he took heart from his remembrance of the lives of these great ideals, the heroes of his boyhood.

Interesting witnesses to his veneration for these great dead remain round the walls of his museum at home in an almost exhaustive collection of their histories and lives, and in many a fine old Napoleonic engraving.

Although Boyd's name will go down to posterity preeminently as an explorer, it is interesting to know that it was his passion for ornithology that formed the mainspring of all his achievements. In his book, "From the Niger to the Nile," he writes: "Every explorer looks upon the map of that part of the world which particularly calls him, and endeavours to find a spot that still affords opportunity for the special powers he may possess for finding out the secrets that it hides. The mountaineer will set his heart upon the ascent of some unconquered height. Thus Ruwenzori, the highest peak of the African Continent, had attracted the attention of many a renowned alpinist, finally to lower its crest beneath the foot of the Duke of the Abruzzi. Other travellers have distinguished themselves in that form of exploration which depends for its success upon a great knowledge of peoples and languages; men like Barth and Burton conquering the desert by their powers of getting into touch with the people of the caravans. The great humanitarian, Livingstone, followed the map as it is expressed by the distribution of the tribes; while geographers, such as Stanley, have left the featureless desert on one side, and taken their ways by hills that make beautiful undulating shadings, and rivers that embroider with blue veinings, and lakes that shine like jewels-upon the map. 
"In Africa Lake Chad was the last gem that remained uncut and wanting a proper setting. There it lay in the desert waiting. For the last decade the attention of many travellers had been turned to it, for the little that was known of it was so mysterious that it appealed very much to the imagination. The fact that it was a desert lake, with the reason of its existence unexplained, stimulated speculation; also it was known that there was an interesting people inhabiting the islands, about whose existence and habits very little had been found out. All these facts attracted me, and there was the distribution of the fauna to establish, with the hope that a locality showing geographical peculiarities might also reveal marked differences in its fauna. This last idea naturally took a strong hold of me, for I will now confess that my ruling passion is ornithology, and all my exploration might be described as taking the course of the birds."

I think that great traveller of ancient days, Ulysses, must have been an ornithologist, for, to hold his course for home, did he not have to blindfold his eyes and stop his ears with wax against the sweet sight and sound of the Sirens, whose bodies were feathered like the bodies of birds? 


\section{CHAPTER II}

\section{HIS EARLIER EXPEDITIONS}

NOW I must go back to the school days. After about

a year and a half spent in the unhappy place I have spoken of, our parents took us away, and I cannot remember feeling a single regret. For about a year after this the family settled near Aldershot, in order that the twins might have gymnastic and riding lessons at the camp, and for the rest of their education they were in the charge of a tutor.

In the autumn of 1888 Boyd and Robin went to Radley, and our ways parted for some years, except for the crowded and eventful holidays. So my personal recollections of Boyd at this period must necessarily be few, for I did not follow my brothers to Radley. This has since been to me a matter of regret, for I have often heard them talk of the inspiration of her fine traditions and beautiful surroundings, and I have had the pleasure of meeting their dear "social" master, Mr. Wharton, beloved of all his boys, by whom he was known as "Kitty." Nor shall I ever forget the excitement of the day when I went with Boyd, in 1907, to hear him lecture to his old school on the subject of his journey from the Niger to the Nile.

After leaving Radley some years were spent by the 
twins in London in cramming for the Army. Here the family took a house in order to make a home for the boys. There is not much that I can tell of this time, for I was away following my studies in another direction. All that come to mind are stories of the amusing escapades that young men kept to a distasteful task and feeling their freedom for the first time usually indulge in ; but I will pass over these.

It was, I think, at this time that Boyd's Napoleon worship got a fresh impetus, and much of his time which should have been spent in more orthodox studies was given to a wide reading of Napoleonic literature and to the ransacking of dusty shops in out-of-the-way places for old prints and engravings connected with his hero. Then, of course, in the holiday times and on every slightest opportunity he was off pursuing his hobby of the birds. For miles round our home the keepers must have been few that he had not made friends of and the wood not to be found that he had not explored.

I suppose it was in these days that he began to be known to the authorities of the British Museum, and to lay the foundations of his friendships with such men as Ray Lankester, Bowdler Sharp, Shelley, C. E. Fagan, and Ogilvie Grant, who, I am sure, must have welcomed a young recruit of so much enthusiasm.

Looking back to this time and the next few years, it is strange for me now to think how little Boyd's family realised how seriously the boy was taking himself, and that this seeming mere hobby was in reality a passionate pursuit that was some day to bring him not only great distinction among ornithologists and a wide recognition among nature lovers in general, who read his frequent articles on the haunts and habits of birds, but also world fame as an explorer. 
These reflections remind me of an occasion when Boyd, as a young man, brought home on a visit the late Captain Shelley, the well-known ornithologist and writer of learned works upon African birds. If in those days my mother was slow to regard ornithology as a serious occupation for her son, it was quite likely that she would not recognise it as a life-study in others ; so when, by way of opening conversation at dinner on the first evening, she said to the old gentleman, "And are birds as much a hobby with you as they are with my boy?" and he replied, "Lord, yes! I'd 'a shot my mother if she'd had wings," she was rather startled but greatly amused.

To those who know what patience must be exercised and what sacrifice of time must be made by one who wishes to become wise about birds and their ways, it will not be a surprise to learn that Boyd's studies suffered sadly in other directions, and that he did not pass high enough in his examinations to obtain a commission in the Rifle Brigade. He had, however, qualified for a commission in a cavalry regiment, but did not take this up, and his annual training with his militia battalion, the 7 th Rifle Brigade, which he had joined in 1893, satisfied his military ambition for a time. For the rest, his energies were entirely devoted to his ornithological work, and he began a collection, and made a systematic study of the birds of Kent and Sussex, spending the spring and autumn of 1896 on the coast, chiefly in a tent at Rye, where he made observations of the nesting habits and migrations of the birds. John Springett, whom I have mentioned before, tells the most exciting stories of his adventures with Boyd at this time. On one occasion, when Boyd was trying to obtain specimens of some rare birds, he chartered a fishing smack and went out in a storm. It was a terrible 
experience. They were driven out to sea, and all night long the pumps had to be worked to keep the vessel afloat; yet Boyd, apparently oblivious to the danger, was throwing out bits of paper to attract the birds within range of his gun. It was two days and a night before the boat could get back to port.

In the same year began to appear the first of his published notes and articles upon birds, which became more frequent as the years went on, not only those of scientific interest in such journals as the Zoologist and Ibis, but also pleasant descriptions, decked in quaint simile and fanciful phrase, of birds and the wild nature of their haunts, which appeared in Nature Notes, the Field, Country Life, and some provincial papers, and appealed strongly to the wider circle of all those who are lovers of birds.

In speaking of Boyd's writings I might give a few observations that I had the opportunity of making of the writer in him. In his nature there was a strong vein of poetic feeling; that is to say, he sensed life by the emotions produced by things and not by his knowledge of them. The fine phrase or graceful image that wakes the inner vision stirred him to the very soul, so that the moment a thought came to be for him worth expression language had to leave the levels of fact and soar to the giddy uplands of poesy. That is why, I think, we find in his earlier writings a tendency to overloading and a lack of simplicity in the description of simple things. For want of judicious pruning the phrases, like heavy, clustering fruit, weigh down the thoughts that branch exuberantly from the stem of a simple truth. In his youthful days he adored the flowery-worded romances of Rider Haggard; then, later, the detailed, pictorial writings of the naturalist, Richard Jefferies, appealed very 
strongly and must have had a considerable influence on his own style. He was a great admirer also of the work of Oscar Wilde, and the false bejewelled phrases of that great writer's verse fascinated him with a charm like the charm of imitation flowers. One found him revelling in the daring artifices of the younger writers such as Crackenthorp, whose description of the butchers' shops in a foggy London street, gleaming with "the scarlet and old gold of hanging meat," greatly tickled his imagination. Then, later, his fondness for a "fruity" style made him a great believer in Stephen Phillips' ultimate survival among the poets, and he loved to quote the speech of his mad Herod, picturing the city he would build, beginning-

"Last night I dreamed of a dome of beaten gold, To be a counter glory to the sun,"

which in my humble opinion, whatever some critics may say as to this poet's tendency to rhetoric, has sounded tones that echo to the very heights of Helicon.

I remember, too, that the shocks of Walt Whitman and the buzz of his busy bee-hive brain aroused Boyd's enthusiasm, but I think that his own constant difficulty with and consequent impatience of form tended to increase his admiration for a master who had conquered form by simply ignoring its existence.

If I have pointed out what seemed to me in his earlier writings some of Boyd's failings it is with a feeling of affection even for these weaknesses, for I am a strong believer in the excesses of youth. And if I take the attitude of critic, perhaps I shall seem more deliberate when I say that I believe that Boyd has written on natural history subjects with a power of observation and 
charm that would be difficult to surpass. I would cite the chapter in "From the Niger to the Nile" on the birds of Northern Nigeria as a model of such writing. Take, for instance, the note upon the cuckoo. Are not the character of the bird and its haunts clearly brought before one in these few, well-chosen observations? -

"During the dry season, when the water is low, the view across the river is often interrupted by stretches of sand-banks and small islands covered with tall reeds and fish-cane, which frequently form snug back-waters, that become the night sanctuaries of many birds. A locality such as this is a favourite home of the Lark-heeled Cuckoo, a rather remarkable bird, that is to be found in the vicinity of most African rivers. It is about the size of a falcon, with upper part a reddish brown and the under a dull white, and a tail powerful and big for its size. It seldom makes use of flight, except to wing its way in a clumsy flopping manner from one thick retreat to another, where at times it gives out a string of rich bubbling notes. The best time to observe this bird is towards sunset, and from an ambush near the water one can watch it almost as closely as one likes. First, one sees troops of doves come down to the pools and take their last drink, and batches of weavers pitch into the reeds with rustling flight for the night. Then comes a brief stillness, to be broken shortly by a creepy noise in the reeds, a tussling sound, as of roots and thick growth being pulled aside. It is the cuckoo working its way in rodent fashion through the columns of the reeds. On emerging into the open it does not neglect to reconnoitre, and climbs cautiously up one of the stoutest fish-canes that overhang the pool ; but there is nothing to cause alarm; merely a lonely sandpiper running along the pool's edge, and a nimble waterhen 
treading the soft carpet of weed. Meanwhile, more cuckoos have crept out from their thick retreats in the same cautious manner, and now one and all begin to call the females to their sides by uttering a series of strong, deep notes, which might be described by the syllables "Ho, ho, ho," in ascending tones. When the breedingseason approaches, the cuckoos may frequently be heard in the middle of a moonlight night. While the river flows through a land of silence they are still wide awake and answering one another with their far-reaching mellow calls, that now and again become rapid in utterance, just like the sound of water bubbling from a long-necked jar."

Or, again, in the description of the forest animals of the Congo, from its minuteness and quaint fancy, can we not construct in imagination the vastness and the faery spell of the Congo forests?-

"Towards nightfall the hunters brought in their strange spoil to their Chief, who then marched triumphantly down the street with all the village following him. The hunters carried many animals as strange as the mysterious forest that bred them; gigantic forest rats with white bellies, two feet from head to tail; others a rich red brown, with backs marked like chess-boards and snouts as long as the snouts of ant-eaters; grizzly mongooses, that rob fowls of their eggs by night, breaking them upon stones before eating them; sweet-faced phalangers, with eyes like saucers and as clear as amber; pangolins, with arched and scaly backs like coats of mail, that steal through the dark places of the forest thrusting their long tongues like swords into the holes of the white ant; buge vampire bats, with teeth like sharks; and many other strange animals that had never before been seen."

Yes, Boyd was not merely an explorer and naturalist 
who had things to tell and told them well, but there was in his nature a deep strain of the artist, who loves beautiful words for their own sake.

But now I must return to the story of his life. Having put aside the idea of a regular military career, he had time to indulge his long-cherished dream of becoming an explorer of birds, and the beginning of the year 1897 sees him setting out with a brother officer of his regiment, Captain John Duncan, upon an expedition to the Cape Verde Islands, where the two friends spent four months in exploring the group, with the most successful results. These were described in a complete paper on the avifauna of the Cape Verde Islands, appearing in the Ibis for 1898.

Finding that his first visit had been too late for the breeding season, he paid a second for the purpose of obtaining eggs, and an account of his further work appears in the Ibis for the same year.

It was on the Cape Verde island of St. Nicolas that he found José Lopez, then a small boy working on his father's boat that plied between the islands. He brought José home with him and trained him as a servant and skinner, and the boy soon repaid the confidence placed in his choice by developing remarkable talents for the varied work of exploration, and by serving his master with distinction through all his expeditions, remaining with him almost to the end.

Poor John Duncan did not long survive his friend, and died in July, 1911. I was abroad at the time, not returning till some months after. I had not heard the sad news, and, believing that I should still find him, I wrote only the other day, July, 1912, to ask him to stay with me, so that we might talk over his old times with Boyd for the purposes of this memoir. It was a great 
shock to me to get my letter back with the bare announcement of his death. He often used to make me laugh with his accounts, which I wish I could recall, of their happy days on the Islands, with adventures sometimes queer, sometimes exciting, invariably coming to an amusing ending. Then he himself would laugh loud and long, and always finish up with the same remark, "'Straordinary chap, Boyd, you know-marvellous fellow!"

In 1898 Boyd joined Major Gibbon's Cape to Cairo expedition, which set out from Chinde in July. In company with his taxidermist, Ramm, of Cley, Norfolk, who had been with him on the Cape Verde expedition, he explored the lower part of the Zambesi and Kafuc Rivers, and made a large collection of nearly one thousand birds' skins, representing 212 species, several of which were new.

After completing his work on this Zambesi collection, the account of which appeared in the Ibis for 1899, he gave soldiering a turn and left England to serve with the Gold Coast Constabulary. I fancy that his object was to save money in order to develop still more ambitious schemes of exploration. However, he was lucky and saw fighting with the force under General Wilcocks at the relief of Kumassi in 1900. This was exceedingly well done, and a bigger affair than most people at home ever realised, but then there were no correspondents, and everybody's attention was at that time directed to the war in South Africa. As the relief column advanced on Kumassi José followed behind and made excellent collections of birds at each station on the lines of communication.

An incident in this little campaign, which shows how Boyd's passion for ornithology dominated all other 
interests, is related by Ogilvie Grant in his article on Boyd, which appeared in the Ibis for October, 1910. He relates how, shortly after the occupation of Kumassi, Boyd being nowhere to be found, General Wilcocks instituted a search for him, and eventually he and José were discovered in their tent outside the fort, though the surrounding forest was still swarming with hostile Ashantis. On being asked to explain his reason for running such risks, he said that if he remained in the fort he was sure to be called on for duty, whereas in his present camp he was less likely to be disturbed and had excellent opportunities for increasing his bird collection!

This story reminds me of a less serious occasion, when Boyd was at a shooting party and the heading gun at a warm corner. After the birds had been pumped over his position for some time and went streaming away without a sound issuing from his gun, his host, on going round to find out the cause, met Boyd coming out of the undergrowth in another direction, proudly carrying a diminutive but rare tit that had lured him away in its pursuit!

When hostilities at Kumassi were at an end, Boyd was sent with a column of Hausas to Gambaga, the headquarters of the Northern Territories. While there he continued his collections, obtaining many rare and interesting birds.

On leaving Gambaga in May, 1901, he formed an expedition, and trekked by way of Salaga and the River Volta to the coast at Accra. Upon this journey he made a fine collection of birds, of which several were new to science, and one, a honey-guide, he named in honour of Sir James Wilcocks. Many of the specimens obtained enabled him to add considerably to the knowledge of the distribution of birds in this little known part of Africa.

I have been told that Boyd was exceedingly popular 


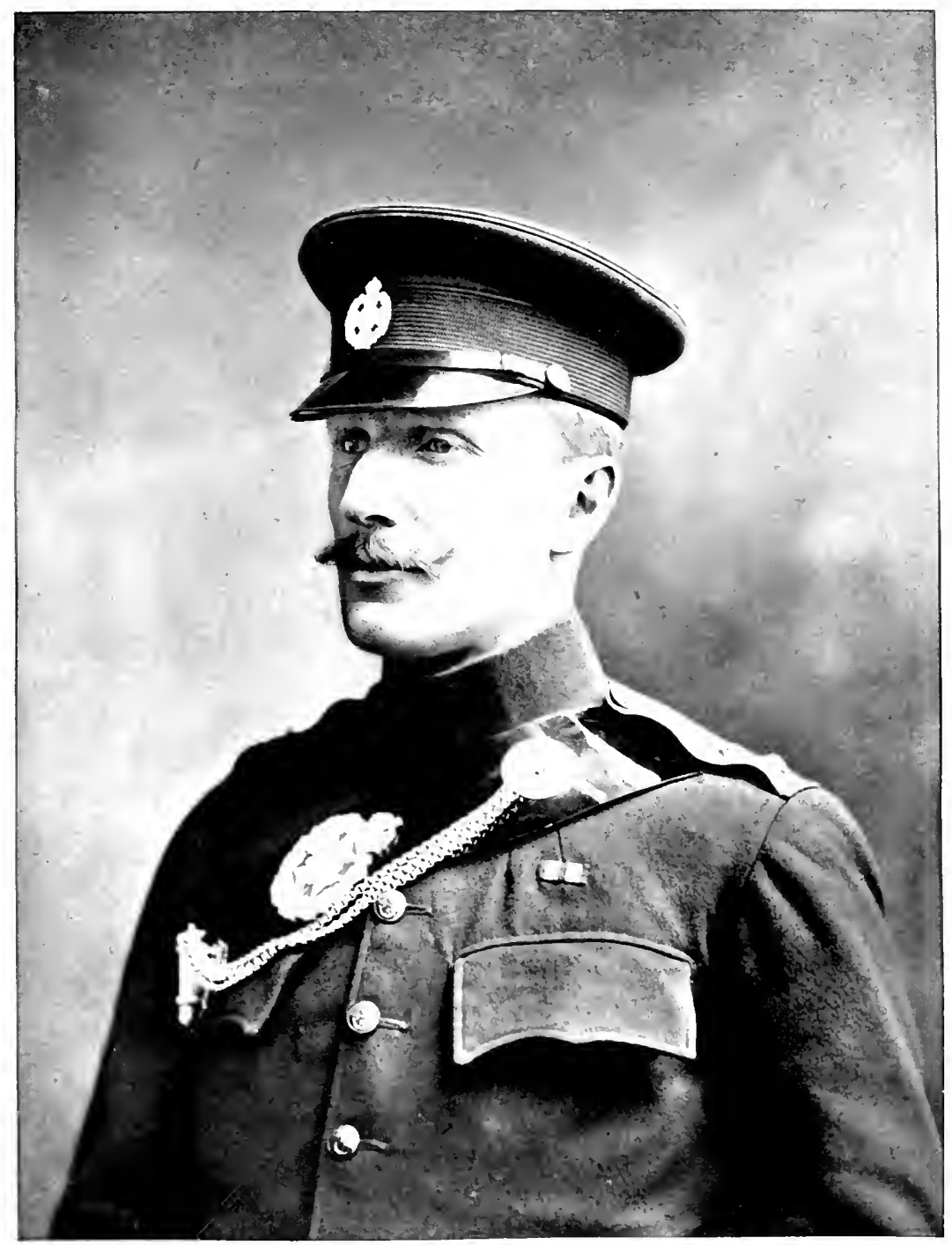

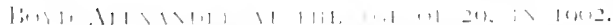



with the native soldiers, and trained those that came under his command to a high pitch of smartness. This was no doubt the origin of their nickname for him, Saritina-Dakaru, or "King of the Soldiers," and for his justice and kindness they called him $D a-n$ '-Allah, or "Child of God." By the by, I am reminded that he was nicknamed "The Duke" by the rank and file of his regiment at home, owing to a likeness in profile to Wellington.

On returning to England, Boyd was offered and accepted a commission in the Rifle Brigade, in the militia of which he was still serving. So for some little time his energies were confined to the parade-ground and Salisbury Plain, and working out his Gold Coast collections in his spare hours.

However, in October, 1902, we find him taking advantage of a few months' leave and making an expedition with José to the little known island of Fernando Po. This was one of his most successful undertakings, and he returned to England at the end of December with a collection numbering nearly 500 specimens, representing three new genera and 103 species, of which 35 were hitherto unknown. He attributed this remarkable success to having traversed the high ground, which had never been worked by his predecessors. A full account, with coloured figures of the more remarkable discoveries, appeared in the Ibis for 1903. 


\section{CHAPTER III}

THE ALEXANDER-GOSLING EXPEDITION FROM THE NIGER TO THE NILE

ND now we come to the year 1904, which saw Boyd
set out upon a project more ambitious than any of his previous enterprises, and one that brought him and his companions worldwide fame.

The mainspring of his idea was to cross Africa by boat, and so point out the wonderful system of waterways that he believed could be made to link up the continent. Dependent from this scheme was the making of a survey in a hitherto little known part of Northern Nigeria, the exploration of the mysterious Lake Chad, and the forming of zoological collections throughout the journey, and with this last the extravagant hope of bringing home a specimen of that rarest and most romantic of animals, the okapi. All these objects were achieved, but not without payment of a terrible price, for of the three Englishmen who started to perform the whole journey only one, the leader, lived to tell the tale. And death claimed a heavy toll from the natives of the expedition as well, for one was eaten by cannibals, two disappeared, probably sharing the same fate, two were drowned while the boats were shooting some rapids, and the last life lost was that of a brave little boy, Quasso, who fell a victim to sleeping-sickness just before the journey's end, but 
struggled on gamely to die within site of the Nile. All these things, and many stories as well of hair-breadth escapes from death, of fighting with fierce tribesmen, of strange peoples and places that no white man had before visited, are told in Boyd's book "From the Niger to the Nile." Therefore, though these events are among the most important of his career, I will not attempt to retell them, but, as it were, use my little lamp, while it burns, to throw light on to some of the paths that lead to and from these more brightly illumined centres of his fame.

No sooner were the records of his last island expedition finished than Boyd set his mind to work on the problems of his new enterprise. His patience and resource in developing a scheme were wonderful. Every available man whose knowledge was valuable to his purpose was interviewed; every book that threw light upon any of the numerous subjects involved was read; the interest of every possible person of power to help on the project was diplomatically engaged. But the most important factor of all in the success of launching the huge enterprise was his good fortune in getting his brother Claud to join him.

Claud had not long returned from South Africa, where he had served with distinction in the brigade of Guards, who saw the war through those long three years in the most glorious manner to the end. In perfect health, and with that bright air of confidence that makes light of all difficulties and is found to perfection in the man who has seen long service in war, Claud was the man in ten thousand for Boyd's purpose. I wish that I had space to speak more of him, for he was surely one of the fairest spirits that any man could call brother and friend. Six years younger, of brighter intellect and possessing 
more talents than his brother, he only lacked Boyd's ambition. But I feel sure that, had he lived, Time would have brought to him in his simple following of duty laurels as proud as those Boyd sought and gathered. He bore an equal share in the expenses of the expedition, and certainly also in the work, but his name has become merged in the name of his brother.

It would seem that Boyd had the talent of his hero, Napoleon, in his power to pick his men, for no braver or more capable little band of comrades ever left England than set out with him upon this long quest. There was that fine soldier and sportsman, Captain G. B. Gosling, a brother officer of Boyd's, whose name will always live in the name of the expedition. He also took an equal share in the work and organisation, but, alas! did not live to enjoy the fame that awaited him.

Then there was Mr. Amaury Talbot, who remained with the expedition as far as Lake Chad, when the survey work was finished and he was obliged to return home to complete it. He, I am happy to say, is still with us, and since the days I write of has brought great distinction on his name by his work and his deeds of self-sacrifice. I look forward with eagerness to the appearance of his book on his labours in Southern Nigeria. It will take its place among the classics. José Lopez, too, added no small part to the success of the expedition, not only as a taxidermist and hunter, but as a responsible commander of men, while his early training when a boy on the sea was invaluable in the management of the boats.

One of the greatest difficulties that Boyd had to contend with was to get leave of absence for long enough to enable him to carry out his big scheme, and the manner in which he overcame it is a good example 
of his extraordinary tenacity of purpose. He had served so short a time with his regiment that it was very natural to find that his colonel did not approve of his plan; indeed, he told Boyd pretty plainly that he would not have a young subaltern of his "gallivanting" about Africa. Boyd then laid his scheme before the War Office, but, Lord Roberts taking the same view as his colonel, the application was dismissed. That would be enough, one would have thought, to cool the ardour of any man. Not so with Boyd, who tried again, this time submitting his scheme to the Intelligence Department. This all-powerful body approved, and so, of course, the matter was settled.

It is good to know that Lord Roberts bore him no resentment for this apparent want of respect for his authority, for the great man, happening to meet my sister some time after the expedition started, asked for news of Boyd, and expressed a hope that "the dear boy would come through safely."

After the second tragedy overtook the expedition at Niangara in the death of poor Gosling of blackwater fever, caught in the fever-laden swamps of the Congo forest, where he was hunting the okapi, Boyd could have brought his long journey to an end with comparative ease, at the same time accomplishing its purpose, by trekking a few days due east to the Nile. But instead of doing this, although sapped himself with fever, and feeling at the end of his strength and in utter gloom of spirit, he went out of his straight course and came in his boat down past the dangerous rapids of the Yei, a river never before navigated. Afterwards, when I asked him why he did this, he told me that as leader he felt the responsibility for his companions' death so acutely, that he purposely pressed his bosom, as it were, 
against the sword of fate that it might have every chance of striking him down as well.

And when he reached Khartoum, Boyd had not seen the end of his sufferings, for as cruel a blow as any was awaiting him there in a letter telling him of the death of our mother a year and a half before.

When Boyd's cable came telling us the news of Claud's death, our poor mother was lying seriously ill in an hotel in London, too ill, in fact, to be told the terrible tidings. Like a condemned victim who is sick and has to be nursed back to meet his punishment, we watched her being slowly brought back to strength till one awful day when the news could not be held from her any longer. She never recovered from the blow, but held on to life, hovering between hope and despair of ever seeing Boyd again, and died eight months after of a broken heart.

Boyd's arrival in England was received with a great deal of notice in the Press, and his first few weeks at home were anything but restful, what with the attentions of the reporters and a heavy letter-bag from publishers, editors, lecture agents, and autograph collectors. The strange thing was to see how surprised he was at all the fuss; he did not seem to realise in the smallest degree what a big thing he had done, and his natural shyness rose almost to panic when I assured him that there was no running away from the publicity which must come as a natural consequence from his deeds. He felt his first ordeal very much of having to deliver a lecture before the Royal Geographical Society of London, but it was such a signal success and received with such breathless interest and enthusiasm by the crowded and distinguished audience that assembled to hear him, that this experience afterwards became a very pleasant 
memory, and gave him confidence for all like subsequent occasions.

I shall not easily forget my impressions of that evening. Boyd was so delightfully unexpected. Friends, who knew of his shyness and remembered his very quiet voice, became fearful that he would never be heard in that most difficult of all places to be heard in, the lecture theatre in Burlington Gardens. But they were agreeably surprised, for his voice rang out clear and strong without any apparent effort, and never has a lecture in that place been better heard. And people present, who did not know him, but had read of all the hardships he had endured, and came expecting to see a rather dried-up, prematurely old man of masterful bearing, saw instead a typical, fresh-looking, handsome young British officer, who carried them in rapt attention along with him as he told in simple language the story of his triumphs and misfortunes.

How delighted he was at the reception that was given him, and particularly proud to hear the kind words spoken by his old chief, Sir James Wilcocks, at the close of the lecture!

Already, six months before he got through to Khartoum, a telegram was awaiting him from Edward Arnold, the publisher, asking if he might publish his story of the expedition. But had it been left to Boyd's decision the story would not have been written, as he felt overwhelmed even with the idea of collecting and writing up the scientific results alone. Then I urged him to reconsider his decision, on the plea that if not for his own part in it, still, for the sake of the memory of those that were lost, the thing should be done. Whereupon he turned to me, saying, "Well, I will do it if you will help me through with it, and we will go halves in the profits!" 
Of course I would have done all I could for him without this most generous proposal on his part. But, as it was, I hope I did my utmost to show my appreciation of his generosity, and from that day to the day when the last proofs were corrected and sent in, my time and advice were entirely at his disposal. For this event in my life I shall never cease to be thankful, for although I was seriously ill at the time, and both of us felt the great strain of working against time so as to keep the publishing agreement, in other ways I was very happy, for I was thrown with Boyd during the best part of a year, in closer companionship than it would be possible for any other circumstances to have brought about.

During this time I came to know him very well. He always seemed to me to have a nature as simple and as hungry for sympathy as a child's, and I have never felt more sorry for any man, for he gave me the impression, even at the height of his fame and surrounded by his friends, of being the loneliest man I have known.

In the first months of our working together, May and June of 1907, we used to plot the chapters while sitting in the sun against the bank of my wild garden at Wilsley. It was on the 24th of May, three years afterwards, I was sitting in the same spot, and recalling the days when Boyd was here beside me, when I received with awful suddenness the news that he had been murdered. And now, two more years have passed, and it is here and leaning against the same bank in the sun I am writing these recollections. So the place has come to be so closely joined with his memory that I could almost feel that his spirit was here to guide my pen.

After working in these surroundings steadily till about the middle of July, Boyd found the interruptions of home too many, and so we went into camp with my caravan in 
the most picturesque surroundings near Corfe Castle, a spot chosen for us by my friend, Charles Dear, a painter and wise vagabond, who came with his sister and camped near us, sharing with us the pleasant evening meal when work for a time was done. With us also was Martin Wood, the writer, who came to try camping as a rest cure. He, like myself, was suffering from an overstrained heart, a condition that forced us to take things very much more slowly than the others, so Boyd nicknamed us "The Hartebeests," a word that was constantly occurring in the course of our work upon the book. Poor Martin Wood may have found rest here for his limbs, but I fear not for his brain, for when the proofsheets began to pour in we kept him busy at reading. $\mathrm{He}$ was good-nature itself.

For recreation, Boyd kept his motor-car in a barn near by, and on Saturday and Sunday used to take a holiday with my friends, visiting places of interest that were within distance. But I was not well enough to go with them.

In September we moved our camp to Studland, to be near the sea, and there we stayed on till November, after the book was finished. I shall never forget the sense of relief and joy that we felt when the last chapter had been sent in. That evening we had a firework display on the edge of the cliff in honour of the occasion.

I have heard since from friends that Boyd used to tell them that he counted this one of the happiest times of his life. The knowledge of this is a very great joy to me.

That winter Boyd was invited by various Geographical Societies to lecture before them, and I accompanied him on a tour including the towns of Newcastle, Dundee, Aberdeen, Edinburgh, Manchester, Liverpool, and Bristol. It was my province to work the lantern and see to the 
arrangements of the halls. Finally, we crossed to Antwerp, where Boyd received the honour of the gold medal from the Geographical Society of that city. These were pleasant days; everywhere we were entertained with the utmost kindness and hospitality, and we made many friends, some of whom I am happy to say are counted among my most valued friends to-day.

At the end of his lecturing tour, my services not being required by Boyd any longer, and my own work having suffered neglect for the last year, I left England for Italy in May, 1908, but not without waiting to be present on the memorable occasion when Boyd received the gold medal of the Royal Geographical Society of London.

After this he stayed some weeks in London, working on his collection from the Niger to the Nile expedition, and later on in the summer spent most of his time at home, where there was plenty for him to do in his museum. No doubt, too, his thoughts were much occupied with plans for his future expedition.

It was at this time that there came to Boyd the most important thing-the love of his life. It is a thing far too near in point of time and too pathetic in its circumstances for me to care to speak of, but I feel that no account of his life could be at all a true one which passed it by, so I will tell the story as simply as I can, in all reverence.

It was one day this summer, 1908, he met for the first time, Olive, the daughter of Sir Reginald and Lady Agnes MacLeod of MacLeod, who live at Vinters near Maidstone. Miss MacLeod came over with a mutual friend to luncheon and to see Boyd's museum. A friendship was formed, which, after only a few meetings, on the part of Boyd ripened into love. I did not hear of this event till I returned to England in September, when he told me. Things had happened so swiftly that it was 
only natural that time should be required for deliberation, and nothing was settled until after Boyd had left England. I myself did not meet Miss MacLeod till after he had sailed, but when we did meet it was easy for me to realise that he was as ambitious in love as he was in his other achievements, and if for nothing else I shall be grateful to his memory for this alone, that he has given me so dear a friend.

The thing that strikes me as so wonderful in the whole story is the fact that Boyd in those few brief meetings was so quick to see, by some sort of intuition perhaps, in this gentle, home-loving girl the heroic, dauntless mate for his own spirit; for truly the journey which she performed and the dangers through which she passed afterwards in order to learn the true circumstances of his death and to pay her last tribute at his grave make a story of devotion unsurpassed even in the pages of romance.

A year of such self-sacrificing tribute to a memory was surely equal to a lifetime of mourning in the midst of the comforts and sympathy of home, and my dearest hope for her was realised when Miss MacLeod, two years after my brother's death, wrote to tell me she was going to be happy continuing her work in Africa, where all her interests had come to be bound up, as the wife of Charles Temple, Secretary for Northern Nigeria.

If a man's greatness can be measured by the love and devotion of his fellows then surely Boyd was great! Amaury Talbot and his brave wife, on hearing of Miss MacLeod's wish to make the dangerous journey to the sad scenes in Africa, in pity for her sorrow and in devotion to my brother's memory gave their services as escort. Without the help of these experienced 
travellers it would have been well-nigh impossible for Miss MacLeod to have accomplished her purpose, and so it is to these three brave souls that our eternal gratitude is due, for had it not been for them it is little likely that we should have ever heard the true history of the circumstances leading up to my brother's death. 


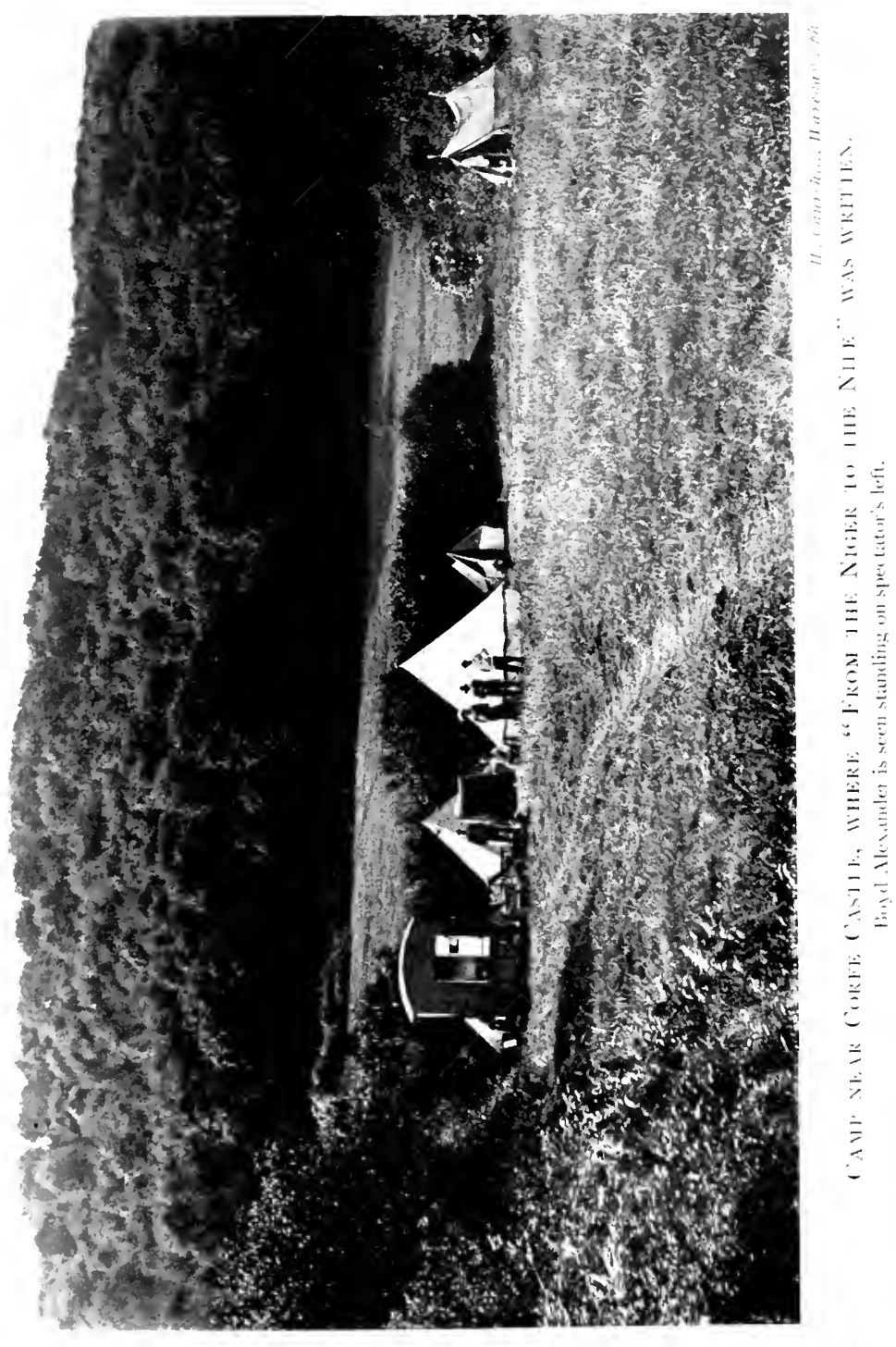



RUT now I must go back to the time prior to his last expedition and endeavour to trace the circumstances that influenced his purpose in setting out on this great journey. Long before, as may be seen from his reference to the subject in his book, he was greatly interested in the political problem that faces England in Darfur. It was his opinion at that timeI am talking of four or five years ago-that we should sooner or later be involved in a war, as has since been the case with the French in Wadai. Here is an extract upon the Wadai situation from his book:-

"It is doubtful if Wadai will be able to disregard the White Man much longer, and if his capitulation can be brought about by peaceful measures, so much the better for all concerned. A military expedition paralyses a country for several years, and it should be the endeavour of all Governments, especially in the Mohammedan provinces of Africa, to sheathe the sword as much as possible, and by propitious and kindly means win over the independent potentates and chiefs, and through them rule their people. After all, they are the rightful owners of the country, and the only excuse for interfering can be on the grounds of pro- 
tecting the community of trade interests. Wadai may yet save his skin, if he choose to follow the example of Ali Dinar."

I remember that he spoke to me on several occasions of the possibility of a peaceful mission, adding that it would be a grand thing to do, to get through to $\mathrm{El}$ Fachir, the capital, and win the confidence of the great Sultan, Ali Dinar, and try to make him see that a whole-hearted acknowledgment of Britain's suzerainty, with active co-operation in the suppression of the slave trade, was the wisest course for his own welfare. This I think was Boyd's chief object, but as far as I know he did not speak of it to another soul for fear of ofticial interference. Besides, it was extremely likely that he would be obliged to turn back, and therefore, however much useful work he had accomplished by the way, his expedition as advertised would be considered a failure. And so he divided his journey into three phases, so he termed them; the first was to make an ornithological collection in the Cocoa Islands of San Thomé, Principe, and Annobon; the second to cross over to the mainland and ascend the Cameroon peak for the same purpose, afterwards following a route through the Cameroons northwards to Bornu, where he wished to visit Claud's grave; and finally, if the fates proved propitious, to fit out a caravan of camels and make the journey through Wadai to Darfur and thence to Khartoum. And we find, by his diary, that had he met with a refusal from the French to let him go through their territory, so determined by this time was he to fulfil his purpose at all costs, that he had actually been experimenting with a dye for his skin, in order, as a last resort, to disguise himself and attempt to get through as an Arab. 
However, this alternative was not necessary, and it will presently be seen that he all but succeeded in his ambitious attempt. For had he waited in Abechir three days longer he would in all probability have accomplished his purpose-a purpose for which his great exemplar, Gordon, also died. And his death by those three days was not owing to misjudgment on his part, but because he pressed forward voluntarily, taking all risks in an attempt to save bloodshed for the honour of his own and in service to a sister nation.

If I were asked to speak of the thing that struck me most about Boyd as I saw him on the last few occasions that we were together, I should say that he gave me the impression that he did not really want to go. There was not the old enthusiasm about him and impatience to be off. Probably his keenness returned to him when he found himself once more upon the old trail. But here in England his outlook on life had changed, a tender vision of a home had come to him and he longed to realise it. Moreover, under happier circumstances he would never have chosen to go alone, at least not all the way, but after the tragedies of his former journeys he never would risk another white man's life again.

When he thought how, of the three comrades who set out to cross Africa on the previous journey, he alone had survived and by so little, it must have occurred to him sometimes that he was leading a forlorn hope against fate to attempt alone this still more difficult quest. My father was strongly opposed to his going, telling him he had done enough, and reminding him of the enormous sacrifices he had already made, and he quoted the story of the pitcher and the well. 
Boyd's reply was, "Well, it's got to be done now, every one expects it of me." Once I asked him why he must attempt such a stupendous journey, and suggested that it would be surely enough to make the island voyage to keep himself going, and his answer was that he could never do a smaller thing now than his Niger to the Nile expedition, and he added, "You see, when once one is a marked man one is not allowed to stop," and then with a laugh, "I don't suppose I shall get any rest till I leave my bones in Africa." This was so different from the man I had seen go out on his former journeys, and filled me with foreboding for the moment. However, as time went by and we heard of his coming safely so far on his road and through so many adventures, I came to believe again in his charmed life.

In the spring of 1910 I was much occupied with a plan of my own and was not worrying about Boyd in the least, when a strange thing happened to me. On the 2nd of April I had spent the evening happily with friends, and after glancing through the papers went to bed a little before midnight and fell sound asleep. About two o'clock in the morming, or it may have been later, for I did not take the time, but judged by the light, I woke up in tears at the horror of a dream. First of all in the dream there was a sensation, not a visual picture, of a gathering terror like the news of a rebellion, then I saw Boyd illumined from the darkness of night, standing up surrounded by angry natives, who were armed. He was trying to speak to me, but I did not hear his voice; rather it was as if the whole air was echoing, "I am in their power." Then suddenly be was swallowed up in darkness.

Next day I was going into the Arts Club, when I met 
a friend, who said to me, "Well, have you had any news of Boyd lately?" I said, "No, not for ages"; then suddenly recollecting my dream I added, "Unless dreams are news." "What's that?" he said. "Have you seen something?" "Don't ask me," I replied; "it is too horrible to speak of."

After this I never had any hope of seeing Boyd again, and as time went on I even told my intimate friends of the dream. One effect it had on me, I could not have said why at the time, was to make me anxious to get to know Miss MacLeod better, and I went over and stayed at Vinters, and we became great friends. I understood why it was afterwards, when I had to break to her the news which arrived seven weeks after the day of my dream. When it did arrive the report said that Boyd was killed on April 2nd, and lately I have heard that his death happened at about six o'clock in the evening, so my dream came some hours later.

The first news of the tragedy, which told merely the bare facts, arrived by telegram, and it was not until some seven weeks later that letters arrived. These told little more than the telegram, and gave no account of the circumstances that led up to the tragedy, so that our minds could come to no conclusions. It was then that Miss MacLeod determined to make her journey, first to Maifoni, where Boyd's remains had been brought to be buried, and then on to Fort Lamy, where she could get in touch with the French officers with whom he had spent the last months of his life.

On hearing of her wish, Mr. and Mrs. Amaury Talbot proved their great devotion to my brother's memory by offering their escort, although they had never met Miss MacLeod before. Arrangements were made with remarkable speed, and the companions started on their 
journey on the 10th of August. On arriving in the country a change in the order of the route was made, and the party went first to Fort Lamy. There Commandant Maillard and Captain Facon, to whose chivalry our family is deeply grateful, told all that they knew of my brother's last days, and handed over to Miss MacLeod his diaries, which had been saved.

In the meantime many conflicting rumours concerning his death reached England and were circulated in the Press. These have never been corrected, and the story has now to be told. Therefore we can never feel grateful enough to the three brave comrades whose untiring labours have enabled me to give the account that follows.

In the beginning it will be as well, I think, to tell a few of the events that happened in the time just before Boyd started from Abechir on the journey that ended in his death.

On his arrival at Fort Lamy he was given leave by Colonel Moll, then commanding the Military Territory of Chad, to make his desired traverse of the French provinces to Darfur, as the country was then considered safe. But before he reached Abechir, the capital of Wadai, fresh fighting had broken out, and when he was at a place called Yao news reached him of the annihilation of a French force. Boyd at once sent forward a letter to the Commandant of Abechir volunteering the services of himself and his men, but the offer was refused.

Abechir had only been occupied some eight months previously, when Moude Mourra, the Sultan of Wadai, had fled without offering much resistance. He was then deposed by the French, who appointed his half-brother, Assil, in his stead. Meanwhile Moude Mourra gathered round him all the malcontents of the neighbouring 
countries, and from that time onwards has caused the French perpetual trouble. On Boyd's arrival at Abechir the Commandant would not allow him to go on, as he considered the country was in too dangerous a state. Then Boyd urged that he might be allowed to continue his journey by the road to Mourra running due east, which he believed to be safe. The Commandant, however, did not share this belief, but suggested two alternatives, either that he should go south and take up the route recently followed by Dr. Kumm, or that he should send a messenger to Ali Dinar, Sultan of Darfur, asking for a safeconduct. Boyd chose the latter course, although it meant the delay of about a month, and accordingly sent a messenger to Ali Dinar with a letter making his request and telling him that he would bring him a present of $£ 100$, a horse and a gun. This was on the 3rd of March.

Towards the end of that month a large body of Furian troops entered Wadai, burning and pillaging villages to within a few miles of Abechir. Before crossing the border they had, while at Nyeri in Dar Tama, seized Boyd's messenger, though his letter, it was reported, had been sent on to the Sultan.

By international law the French might not carry reprisals into the British sphere of influence, and were the invaders proved to be really Furians, might claim an indemnity, and the matter entail serious diplomatic negotiations.

With the consent of the Commandant, Boyd set out from Abechir to ascertain the facts and investigate the amount of damage done, in order that he might draw up a report upon the situation. He left some of his things at the capital and gave the Commandant his word to return. 
He started on March 29th, and on April 2nd, having already collected much information, found himself within a day's march of Nyeri, the capital of Dar Tama, the place where his messenger had been seized.

To make the position clear, I must tell you that the Chief of that country, Othman, had been deposed by the French a few months before, who had appointed another in his place. The latter was, however, soon overthrown by the Massalits. Othman, who had fled to E Fachir for protection, was now reinstated by Ali Dinar's troops, and entered his capital, Nyeri, on the 8th of March.

While Boyd was engaged on these investigations news was brought to him of an impending combat between the Furians and a French column under Captain Chauvelot. He therefore determined to hurry on towards Nyeri, in the hope that he might be able to intervene as an Englishman between the two forces, and so prevent bloodshed. But the three emissaries, who had been sent by Assil, Sultan of Wadai, to accompany him on this little expedition, begged him to turn back, as they thought the risks too great. He would not do so, and they returned to Abechir without him. José had added his entreaties to theirs. He knew that if he turned back the Hausas would throw in their lot with his; so, thinking to deter his master from what he considered too dangerous an enterprise, he also refused to go on. Whereupon Boyd rode forward alone.

Finding that his action did not have the desired effect, and realising that he never could go back to Abechir without his master, José went forward once more with the Hausas and overtook Boyd after he had been some hours upon his march alone towards Nyeri.

People have been inclined to blame Boyd for fool- 
hardiness, but he believed that Ali Dinar's principal men were at Nyeri, and, had he been able to get into personal touch with them, he might have succeeded in his humane object.

It was obvious that the little party came in peace, for their only weapons were two revolvers and a rifle, carried in the baggage.

At 5.30 in the evening they reached a little village called Ilarné, a mile from Nyeri, where they made their camp beneath a big tree by the roadside. Boyd sent at once to advise the Sultan of his presence, and to say he would visit him next morning. Accompanied by two Furians, the village people brought him the customary present, but they seemed so excited and unfriendly that José begged his master to take the money and papers on their horses and fly while there was yet time. But this Boyd would not do.

In an hour's time the two Furians returned, together with some of Sultan Othman's men and a crowd of natives, all armed with clubs and rifles. They ordered Boyd to come with them to the Sultan. No white man could submit to such treatment, so he quietly refused, but at the same time repeated his intention of going next morning. Then some of them laid hold of him and attempted to drag him off, while others seized upon the camels and the baggage. Meantime José ran for his rifle. It was unloaded, and he could find no ammunition. But he pointed the weapon as it was at the men who were running up to seize himself, and pretended that he was about to fire.

At this they fell back a moment, not daring to attack him, and he was thus able to gain cover in the bush by the roadside. At the same time he heard a shot, and saw Boyd surrounded by men who were striking him with 
clubs, while his master defended himself with his fists, calling out all the time "José! José!"

Believing himself to be powerless to help, José succeeded in escaping, and luckily finding his horse rode into Abechir on the 5th of April, where he made a deposition before the Commandant.

On the 7th of April, five days after the murder, Captain Chauvelot, in command of the French forces, met and defeated the Furians at Guereda, and found among the enemy's deserted baggage upon the battlefield a box belonging to Boyd. It had been broken open, but the diary and a few papers were left in it. This was the first hint Captain Chauvelot received of the tragedy. Native rumour, however, soon supplied details, but the French officer lost no time in pressing forward in the hope of rendering assistance. At the same time the Sultan of Wadai's messenger reported to him that he had just come from Ali Dinar, who had treated him with civility, and had given him letters, both to the Sultan Othman and to his general, Abdul Rashid, with instructions that the utmost consideration and assistance should be given to Boyd. These letters arrived five days too late.

On his arrival at Ilarné Captain Chauvelot found Boyd's remains half buried beneath a pile of stones. Death was due to a rifle-shot and to blows from clubs and stones. For fifty yards the ground bore marks of resistance; then they ceased, and the track of the body on the earth was even, showing that the struggle was at an end.

Most heartfelt gratitude is due to Captain Chauvelot and his companions for the minute study they made of every detail, and for the care and reverence with which they brought the remains to Abechir.

From Abechir they were carried to Fort Lamy, and 
thence to Maifoni under José's charge. There Boyd was buried with full military honours beside his brother Claud.

It is strange to think that though they died nearly a thousand miles apart the two explorer brothers now lie together in the little graveyard under the tall white-flowered acacia-tree, the spot that Boyd had chosen for Claud's resting-place four years before he came to join him. Just a little way off, the fort stands looking out across a great stretch of country from the summit of a slope. Here the sentry on his rounds guards the graves, and every hour the bugle sounds over all. For a year and more Claud lay there alone, but afterwards others came to join him and the little graveyard has been enlarged. There also lies the great explorer Overweg, whose bones for a long time lay lost in an unknown grave near Lake Chad. The graves are bright with flowers, and over those of Boyd and Claud stand a headstone and a cross carved by Alexander Fisher. The headstone, which is upon Boyd's grave, was taken out from England and set up by Miss MacLeod and her companions.

Here at home the fame of the two brothers will endure in a memorial in marble by Professor Colton, A.R.A., that will shortly be set up in the Parish Church by the subscriptions of some of their fellow-citizens of Cranbrook and admirers throughout the world.

When the news of my brother's murder struck its terrible blow at home, if there was one thing that lightened our sorrow it was the proof of universal sympathy that we received. In the days that followed letters and messages came from all parts of the world, not only from personal friends, but also from official bodies of great nations, from people unknown to us but who admired Boyd's fame, and from others who felt they were his friends through reading his book. 
I give the following words spoken by Mr. Amaury Talbot when lecturing before the Royal Geographical Society soon after the sad news came home, for they form a tribute very precious, seeing that they come from a man himself distinguished in the field of exploration, who was a comrade of my brothers. Afterwards by his deed of self-sacrifice he proved the perfect sincerity of his words :-

"Save for one thing, it would not only be out of place, but hopeless for me to try to add anything to the remarks of the President on the loss which we have sustained by the death of Boyd Alexander. Many here to-night knew him, and none could know him save to hold him in high esteem; but when one has been alone with a man for long spaces, far from civilisation, one grows to know him in a way which is not possible under smoother conditions. It is only six years since Captain Gosling, Claud Alexander, and myself started under the leadership of Boyd Alexander for Lake Chad. That all three were brave men goes without saying, but to have spent a year in the company of three men of such courage that danger seemed either non-existent, or only to exist for the sake of being overcome-three who, worn with fatigue and illness, often half-starved, and exposed to constant danger, never for one moment wavered in cheerfulness and the most selfless thought for others-is a privilege to remember for the rest of one's life. I am grateful, Mr. President, for this chance of expressing even so inadequate a tribute to their memory. It is almost with a feeling of apology that I stand before you to-night, when men so far better have gone from us."

In conclusion, I would say that the writing of this memoir of my brother's life has been a difficult and often a very painful task. It is so soon after the sad events of 


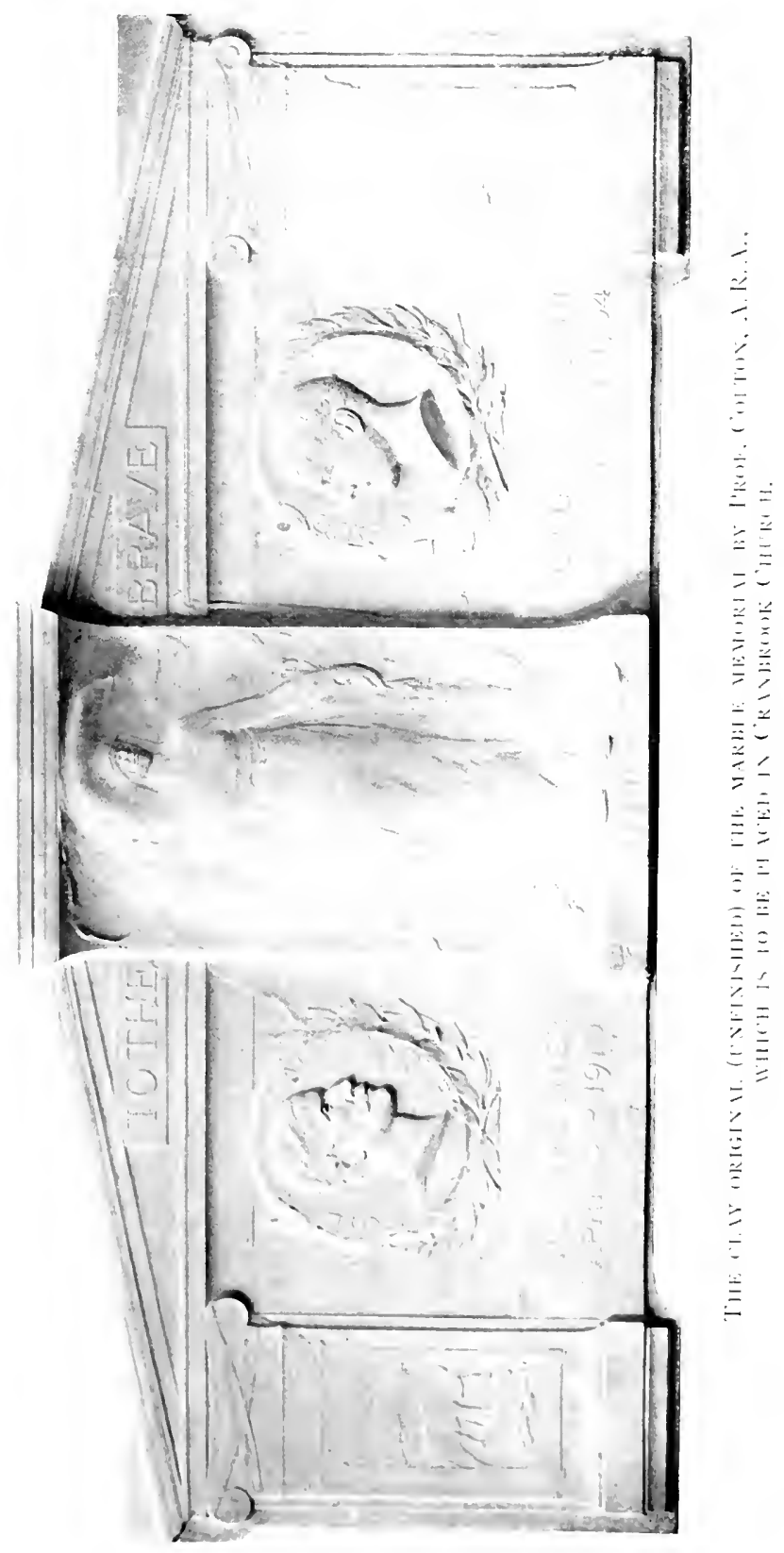



its close, that I have had to live again, as it were, through the horrors of that time.

I am deeply conscious, too, that disabilities of my calling have forced me to rely too much upon the smaller details of life at home in my attempt to draw Boyd's character, while I have not treated at all adequately the larger qualities of his life of action abroad as soldier and explorer.

I wish I had the power of a great writer to draw the portrait of my brother as I see him now. There he stands, a lonely and sorrowful figure, carved in great simplicity like a Michael Angelo. Finished are the eagle front and steadfast eyes gazing from deep shadows to a far purpose. Finished also are the worn, sensitive hands, that are burnished bright by the touch of romance. But unfinished the form and limbs struggling for expression from the weight of stone that imprisons them with an eternal tragedy. Surely he is one of the most picturesque figures of his time! 


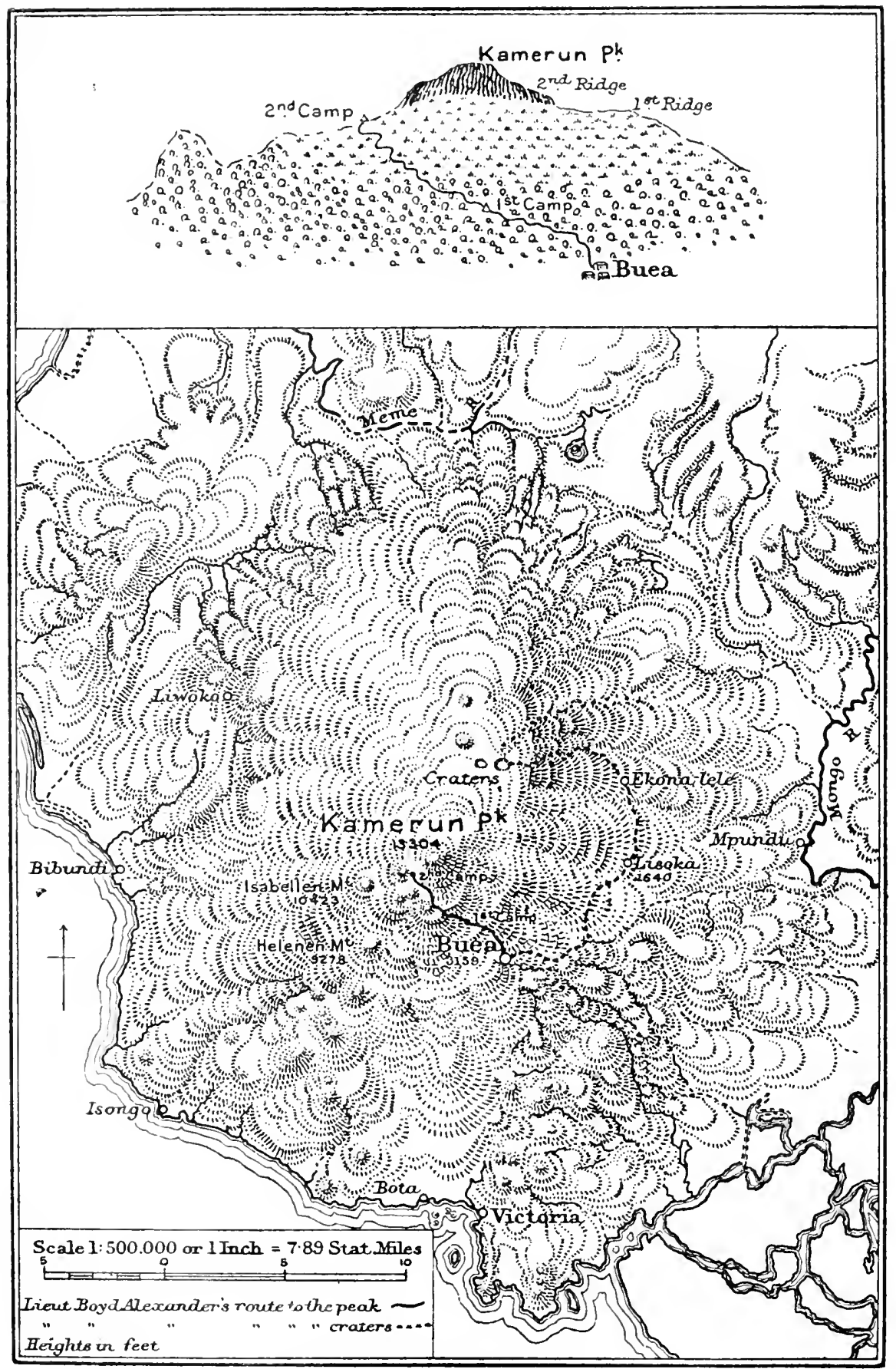

MAP OF THE KAMERON PEAK. 


\section{INTRODUCTION TO THE DIARY}

$\mathrm{T}^{\mathrm{T}}$ is now nearly four years since my brother began 1 the diary of his last journey, so that I doubt if much of the information that it contains, except the startling notes from Abechir, will be fresh to the reader who is familiar with things African.

The important observations on his unique experience in the great eruption of the Cameroon Mountain in April, 1909, were sent home by him to the Royal Geographical Society at the time, and the intensely interesting and valuable revelations regarding the situation in Wadai just before his death were in our hands in time to be of service to those responsibly interested in events in that region.

But my brother's Diary is not being given to the world on account of its intrinsic value as information, but because it must prove of great interest to his many friends and admirers as the record of his last work, for which he gave his life, a sacrifice yet to be acknowledged by his country.

I, myself, have read his notes with an added regret, for being by circumstances familiar with his methods I could realise all that we have lost. Never before had he kept a diary on his journeys, relying instead upon an extraordinary memory for even the smallest details, which he was in the habit of recalling by going over his careful route-maps. But for writing a book of travel this is a system entailing the cost of tremendous efforts, as he found when he was engaged upon his last work; 
and so before he went out on his next journey I urged him to change his habit and begin keeping a diary, not leaving unrecorded even what might seem upon the spot the most trivial happenings, for these would afterwards serve as useful sign-posts to the memory.

To read the results of my suggestion is like looking at the studies for a picture that the artist has not lived to paint. It may be there are parts that are overlaboured in the details and awaiting the simplifying sweep of the brush, while there are others in vital places left vague for the decisive master-strokes; but all are drawn with an eye most careful for the truth, and would have enriched even though they might never have shown in the finished work.

As we read on, more than once we seem to catch the note of coming doom, but perhaps this is only because we have foreknowledge of the end. Apart from these few melancholy suggestions, I should say that the prevailing characteristic of the Diary is its serenity. When we try to picture only a few of the hardships of such a journey; the long periods of loneliness, the monotonous food, the frequent mutinies, the lowering effects of recurring fever that induce despair, and last, but not least, the petty insults of mean-souled officials, we are astounded at first, but then we come to realise that after all this is the secret of such men as my brother; it is their serenity of soul that enables them to endure to the end.

There is a characteristic and pathetic note on the flyleaf at the end of the Diary. It is dated January 3, 1910, but does not come in the order of days. It is written in a faint, shaky hand, almost illegible, and runs: "Am feeling very bad; it must be the results of the poisoning; but never say die!" Yet once over the 
trouble no mention of it is ever made in the following days! And this sort of thing happened more than once. José told me that on another occasion Boyd, not long before he reached Abechir, was so ill with a fever very like blackwater in its symptoms that he gave himself up for dying. He wished to make some bequests, but was too weak to write, so José wrote them down for him to sign. The paper was afterwards lost (or perhaps on his recovery Boyd may have destroyed it), and José could remember only two of the wishes that were expressed: one was that his master's collection of African birds should be given to the British Museum, and the other that he himself should receive a legacy of $£ 700$. Both these wishes were afterwards carried out by my father.

This last instance recalls a similar one on his former expedition. Boyd, but recently recovering from blackwater fever, was travelling alone, and at Bautchi suffered such a severe relapse that he believed he could not survive. Yet, when afterwards he was writing of Bautchi, although I questioned him most closely as to every detail of his stay in that city, the fact of his illness had apparently gone clean out of his mind, and I should never have heard of it had I not come quite by chance among some old papers of his years afterwards upon a will (or what he described therein as his last wishes, as there was no witness present), stating his belief that he was dying, and making, among other bequests, the same one of his African collection, and also the one relating to José, but the latter was, of course, proportionate to José's shorter service at that time.

If we must regard the Diary as a fragment compared with his former work, still I think it is certain that 
no book ever came to the light under more tragic or more romantic circumstances. When all else of value that he possessed had been looted by his murderers, the two volumes of his Diary, as has been told before, were found untouched in a broken box upon the battlefield of Ilarné by the French, who, led by the warning, pressed forward and recovered his bones. Nearly a year afterwards the Diary was handed over by the French to Miss MacLeod, who, with her two brave comrades, made the long and perilous journey from England to Fort Lamy for the express purpose of learning all that could be told of the circumstances of my brother's death. But before sending the precious books home to us, in case any mishap should befall them on the way, Miss MacLeod and Mrs. Talbot made a copy of them-a task that must have been doubly laborious under the trying conditions of African travel. Alas! the route-maps, which Boyd tells us in the Diary he made the whole way from Maifoni to Fort Lamy, and thence to Abechir, have never come back. And of the photographs, although scores of good negatives reached us in safety, comparatively few are of any value, as there is nothing by which to tell the subjects that they represent. However, for the miraculous rescue of the Diary, which has come back to us like a voice from the dead, we can never cease to be thankful; for without it we should know very little indeed of that year and a half of patient struggle, and it would have seemed as if for the last year he had gone out into the dark, only to appear to us again for one awful instant in the red gleam of a violent death.

H. A.

The Ark, Studland.

August 8, 1912. 
BOYD ALEXANDER'S DIARY 

THE SAN THOMÉ-CAMEROON EXPEDITION, 1908-1909

December 12, 1908.-Left Liverpool in R.M.S. Akabo. Commander, Captain Roberts. Had telegrams of good wishes from Father, Marion, Englishes, Sir Alfred Jones, Robert Cheeseman, and a letter from O. M. This I was very glad to get.

December 18.-Arrived at Las Palmas after a not too smooth passage, but all this is forgotten under a warm sun and in calm waters.

December 23.--Sierra Leone, distance from Las Palmas 1,220 miles, the first point on the African coast. I always experience a feeling of pleasure at seeing the black face once more. I feel as if I had never left the country.

December 27.-Axim, distance from Sierra Leone 807 miles.

Same day.-Sekondi, distance from Axim 46 miles.

José * came on board with twenty carriers, Hausas and Mendi. They seem a useful lot. He had also with him a cook and two boys.

* José Lopez, from San Nicolas, one of the Cape Verde islands. $\mathrm{He}$ had served Boyd throughout all his expeditions, extending over a period of thirteen years.-ED. 
José had left Liverpool by R.M.S. Fallaba on December 5th, with the object of collecting these men at Cape Coast, but fortunately the Governor, Sir John Rodger, came on board at Axim, and after receiving the letter from me which José held, he advised Sekondi as the best place for collecting the carriers, and he gave the necessary orders.

Cape Coast is no longer what it used to be, the railway at Sekondi having taken away all its trade.

December 27.-Cape Coast, distance from Sekondi 27 miles. A letter from the District Commissioner asking me to dine with him. The Government officials have been very obliging and kind to me, and I thoroughly appreciate it.

December 28.-Accra, distance from Cape Coast 68 miles. Went ashore and had breakfast with Sir John Rodger at Christianborg. It was on just such another occasion in March, 1904, I was there with Gosling; it awakened sad memories. Pickles* was not with me then, as he had some shopping to do in the town.

December 29.-Lagos, 220 miles.

December 30.-Forcados, 120 miles. General Morland, who came on board at Accra, left the boat here. Captain West, a fellow-passenger from Liverpool, left with him. I gave him a box containing cement, \&c., for the repair of the cross $t$ at Maifoni, and if all goes well I mean to visit the place on my return journey. The fore-deck is now crowded with native passengers, the quiet Hausa, sitting on his mat waiting patiently for the hour of prayer, jostling with the Kroo boy, Yoruba, and many other

* Nickname at home for my brother Claud.-ED.

t The stone cross, carved by Alexander Fisher, that marks the grave of Claud, who died at Maifoni November 13, 1904.--ED. 
nondescripts. As soon as daylight comes the gaffering outside my cabin is prodigious, and this discomfort is increased by the crowing of innumerable fowls, huddled in larger wicker pens or baskets, and belonging to different traders who carry them between this place and Bonny.

December 31.-Arrived Bonny, distance 80 miles. A small station on a low-lying strip of land on the Bonny River with an unhealthy-looking lagoon behind.

January 1, 1909.-Arrived Calabar, distance 45 miles up the Calabar River and altogether from Bonny 140 miles. Went ashore in the evening and witnessed the New Year's sports, in which the natives of the various Government bodies and firms took part: hundred yards race, obstacle race, high jump, bicycle race, \&c.; altogether a good show. There were some wonderfully well-developed natives, especially amongst the Ebors, but in spite of this their staying powers are not great and they collapsed quickly. I was introduced to the Provincial Commissioner, W. Fosberry, who kindly asked me to stay at Government House while the steamer was in Calabar. Last time I was here was in 1901, when it was the seat of Government, now transferred to Lagos. The place since then has increased and improved a great deal; in fact, I have no hesitation in saying that it is the finest station of our West Coast possessions, and for several reasons. The buildings are well placed, and, what is most important, they are away from the native town (Duke Town), and the station is situated on an eminence 150 feet in height. When coming up the river, this geographical feature comes as a great surprise, for the banks of the river are vast mangrove swamps till this point on the left bank is reached. The best situated houses are those belonging to the Hope Waddell Institute, consisting 
of four well-built houses overlooking the river. The prison is well worth a visit. The solitary cells number over fifty; the whole is a perfect and well-ordered miniature, down to the execution shed, of our home prisons. Prison life to the black is not that awful experience that it is to the white. The black, from time immemorial used to domestic slavery, has not been taught to think; he is a machine, only used to manual labour, so our system of prison life is not that irksome burden that it might seem to be. Here is a story illustrating this: It happened at Calabar a gang of prisoners were out working, when one of them threw down his matchet and made a bolt. This was a signal for all the other prisoners to give chase, and it ended in the runaway being brought back by his fellow-prisoners. The native hospital (Dr. Taylor, a Canadian, in charge) is a well-arranged institution containing a fine operating-room. To natives in Government employment a daily charge of $1 \mathrm{~s}$. is made, to others $2 \mathrm{~s}$.

The coffee in the botanical gardens is still being cultivated. Beyond the gardens are rubber plantations containing five thousand young plants, the most flourishing kind being the Para plant, and no doubt the one that should be used for the colony. These plants are now about eighteen months old and have attained a height of fifteen feet. At the present time palm oil and kernels are the chief exports, and to these Calabar owes its present prosperity. Hitchens of the Forestry Department tells me that only 6 per cent of the palm-trees in the Protectorate are drawn upon. He calculates that every tree gives a yearly yield of $2 \mathrm{lb}$. of oil and $6 \mathrm{lb}$. of kernels. Rubber cannot be reckoned with as an export for some years to come. In Brazil, I am told, the Para plant is not tapped till it is twenty years old. 
January 2.-Cabled to London and County Bank for $£ 100$.

Jamuary 3.-Took several photos of the town to-day, but the Harmattan season makes the atmosphere very hazy.

January 5.-Dined with South Nigerian force at their new barracks, some two miles from Calabar. Captain Fox in command in the absence of Colonel Trenchard, who is away conducting operations to the north of Cross River. Had a very enjoyable evening.

January 6.-The West Africa Bank (manager, Edmonds) received for me $£ 100$. This I drew. Left Calabar for Fernando Po (distance 85 miles), and arrived towards midday of the 5th off this island, but the mist was so thick that at first the captain was unable to find the port. The mountain was of course invisible, reducing the aspect of Fernando Po to an ordinary wooded island, and it was only towards sunset that its shadowy outline came out. What a magnificent little harbour! The bay almost makes a complete semicircle, the right arm looking seaward and in formation giving the impression of a steep natural wall. Just near its point a stone pillar marks the grave of Commander Beecroft. The sight of this place awakened pleasant memories, carrying my mind back to 1901, when I ascended the Peak and made a remarkable collection of birds. I was told that the British Museum collector, Seimund, did not do much on the island, and I firmly believe it would repay another visit, especially to the south side. Towards evening I went ashore and was disappointed to find that the fine mangrove avenue has been spoilt by a number of trees having been cut down. The Roman Catholic church was a good deal nearer completion than when I last saw it, the roof being finished. 
At one end of it, near the coping, its brilliant Padre, Don Miguel, was to be seen, an aged man almost bent double in the work of erecting this church, which he has done all by himself with the help of a few blacks. It has occupied over eight years, a truly marvellous piece of work for one man. The old Father says his great ambition is to finish it before he dies, and may he live to do so!

January 8.-The Spanish Colonial Secretary, Diego Sevadra, at the head of a company from Madrid to inquire into the administration of the island, was on the yacht Corisco. I went to see him with Barrow, a trader bound for Elobey and well known to the Spanish authorities in these parts. Sevadra seems a nice man, and has offered to take me on the Corisco to Annabon, leaving San Thomé about the 24th. From here I called upon the Governor. His house was dirty, ramshackle, and typical of Spanish decay. He seemed quite amused at my wanting to go to Annabon, and thought I could do all I wanted there in an hour. He promised me a letter giving me facilities, \&c., but needless to say it never arrived before the steamer left. I should not think that any new life could be infused into the colony by an old man of that kind. The depressing effect of this visit was quite counteracted by the charming cordiality of the Padres, whom we next visited, the head Father being Ranola and the second Albanell, both of whom I had met previously. They told me that sleeping-sickness was very bad on the island, and that there is great infant mortality. Ranola at once gave me a letter to the Mission station at Annabon. Ranola has been at Fernando Po some twenty odd years. There are sixty small Bubi boys at St. Isabel, another ninety at their Mission at Basile, and many more at their other stations. The present generation are being taught Spanish; a copy-book 
belonging to a boy of four years old was shown to me. The writing was excellent; the last lesson was a geographical one, and there was a list of the African rivers written down. While at Fernando Po, a Kroo boy caught close to the steamer at Shearwater, which José has skinned. This will be an addition to the island fauna. I think it is $P$. griscus.

January 8.-Left about three o'clock for Victoria. Just at the last moment a German arrived with his letters. (Each agent comes off with his own letters, no one ever thinks of trusting them to the Spanish Mail.) He sent his boat back, and disappeared aft to the purser with his letters, presently returning to find the steamer under weigh. A big German with close-cropped hair, standing on the ladder and waving his hands frantically like the arms of a windmill to the boat, which was returning to the rescue but was making little headway, was a funny sight.

Arrived at Victoria just before night, and was able to catch a glimpse of the Cameroon Peak, which was an imposing sight, with its smaller sister peak lying to its right. At the entrance of the harbour are two small wooded islands, Ambas and Mondoleh, and almost in line with the former and nearer the mainland a chain of needle-shaped rocks, almost an exact replica of the Needles at home, and indicating a part of the same upheaval. Williams, the agent for Holt, came on board, and he very kindly made arrangements for me to go up and see the Governor at Buea the next morning by train, and the captain said he would wait for me.

January 9.-Left by train at six o'clock, and after three and half hours' journey arrived at Soppo, the terminus, forty minutes' walk from Buea. This railway is quite a 
good piece of construction; it is small and light and travels at a rate of eight miles an hour, ascending the whole time the slopes of the big mountain, which are cultivated right up to Buea with cocoa and coffee plantations.

Though a telephone message had been sent to the Governor that I was coming to see him, I found myself walking up from Soppo to Buea, and after a hot walk arrived at his palatial house. I sent my card in, and was kept waiting outside in the hot sun for some ten minutes. Then I was beckoned in by a black soldier and met the Governor coming down the stairs. We shook hands, and he took me into one of his rooms. I explained my reason for coming, and, although he had been informed of it by his Government, he seemed to know nothing about it. At my request to be allowed to go into the Manenguba Range, and then possibly on to Yola, he said he thought there would be no objection. His manner gave me the impression of a man wishing to be civil and that's all. I asked him how long it would take to walk back to Victoria, and he replied, "About four hours," and so I went away still sweating and thirsty.

Before leaving he advised me to see his secretary, Hansen, who would be acting in his place on his leaving for Europe on the 9 th of February. I saw him, and he knew all about my case, and I told him I should return in May. I managed to catch a train taking down palm kernels, and so saved my four hours' walk. I arrived at Victoria about three o'clock and was told it was the quickest journey on record to Buea.

Buea is a fine station, full of well-built houses; the Governor's house, which is quite a palace, is said to have cost a fabulous sum, $\mathfrak{2} 35,000$; this is German colonising all over. Before leaving Victoria I bought ten pieces of 
fine calico, $4 \varsigma, 6$ d. each, to make mosquito nets for the men, as the Padre at Fernando Po told me that the mosquitoes were very bad in Annabon.

January 11.-Left for Rio del Rey on the 9th, but the Harmattan mist was so bad the next morning, that the captain was unable to find the buoy at the entrance of the river; the horizon was quite blotted out by the mist. So we remained at anchor till to-day, when the Harmattan cleared somewhat, and we arrived at the station towards noon. The station consists of two factories, German and English, the latter on the left bank ; both have been built on the river's mud. What little firm ground there is has been made artificially with cinders from the steamers. The river presents much the same aspect as the Calabar and others on the coast, the banks showing nothing but the eternal green of mangroves. The bark of the mangrove was shipped at one time for tanning, but this is no longer done; the wood is extremely hard, even turning the blade of a knife.

January 12.-Arrived at Duala, twenty miles from the mouth of the river, about 9 a.m. Near its mouth the river is a vast sheet of water, four miles in width, with many estuaries. Duala is a large town, and the Government buildings have been erected regardless of expense. Some fifty kilometres of railway, eventually-I believeto reach to the Chad region by the Manenguba range, have been completed a little higher up the river on the right bank. The firm of Messrs. King has been established here 120 years. It must be one of the oldest trading stations on the Coast. At one time the merchants used to live in hulks on the river, and the old transport ship, the Lord Raglan, which had carried so many troops out to the Crimea, was used in 
this capacity. The health is not very good; there have been several cases of blackwater lately.

The chief imports are salt and rum; as many as a thousand twenty-gallon casks have been landed by the steamer. This is the chief thing paid to the natives for palm oil, six litres being given for twelve gallons of oil. I am told that this place is groaning under the taxation of the Government. One shilling per kilo on ivory, five thousand marks, or $£ 250$, to kill elephants for ivory, and a hundred marks to shoot an elephant, while the limit is three elephants $(\mathfrak{2} 25)$.

January 14.-Arrived Plantation, a small German station. The seaboard now is thickly wooded, the monotonous dark green of the foliage is seldom relieved, except perhaps here and there by patches of elephant grass that look paler green against the predominant shade.

During the last day or two the evenings have been delightfully cool with strong breezes from the south-west. A great trade is done here in salt; we landed here two thousand bags.

January 15.-Kribi. A well laid-out station and a prosperous one. The country is again thickly wooded, and marked by broken hills-cone-shaped, and saddlebacked and wooded to their summits. A lofty hill, lying about nine miles east of the station, and some 1,700 feet in height, makes a conspicuous object in the landscape. There are others, still higher than this one, lying to the south, the chief being Mount Alouette, which is nearly 4,000 feet in altitude. Objects of interest to note here are the native fishermen, recalling at once to my mind the method of fishing on the River Shari, that of sitting straddled-legged across a faggot of 
ambatch.* But in place of this the Batanga fishermen use very light canoes, about eight feet in length and very narrow, there being just room for one man to sit in. They fish with hook and line, sitting the while with their legs in the water. The secret in handling their little cockleshells of boats is their method of balance, and they do not fear to go several miles out to sea.

I went ashore about ten o'clock and left to photograph some remarkable falls made by the Lobi River, about five miles distant, and on the way to Batanga. The water falls abruptly into a small bay of the sea from the height of some fifty feet. It is a fine sight. The volume of water must be very considerable in the rainy season.

The German authorities have just formed an ordinance which comes into force in December, levying a tax of six marks on every workable native, or in lieu thereof one month's labour.

In these parts rubber and ivory are the principal exports. A great deal of the old rubber has been destroyed by the natives cutting the vine.

Here I heard of Bates, who has in the past made some good collections of birds for the Natural History Museum. $\mathrm{He}$ is now on the Ja River, and is married to a black woman. He has been a number of years in Africa, and was at one time a missionary.

Last night a little Stormy Petrel flew into the saloon while we were playing cards; this makes about the fifth to do so on this voyage. I always give these little way-

* Vol. i., page 11.-Ambatch, or Maria Bush, a slender tree with small leaves of a very dark green. It attains a height of thirty feet. The substance of the wood is pith-like and fal lighter than cork. The Buduma of Lake Chad use it for their nets, and also as floats; beams six to eight feet long with the end curved like a prow, upon which they swim with a double over-arm stroke, attaining a pace of eight miles an hour.-ED. 
farers a lodging in my cabin for the night and then release them in the morning. It is useless to free them at night, as the glare of the lights only brings them back to the ship again. They are charming birds, and the amount of confidence they show in one is remarkable, nestling in one's hand as if they had known one all their lives.

January 16.-We made Batanga in the same day as Kribi, from which it is only distant about eight miles. Batanga is a small place, much enclosed, and with two factories, German and English. At Kribi there is quite a large Hausa colony, the Hausas coming down here many miles from the interior with rubber and ivory.

Arrived at Bata (Spanish), a wretched-looking place, and not less typical was the official boarding boat, a dirtylooking surf craft, manned by three still dirtier-looking natives, a startling contrast to the German and our method, when it is quite a pleasure to see, as soon as the anchor is let drop, a smart gig manned by natives in sailor costume come off from the port.

Bata is quite a small place, containing German and English stores. They bitterly complain of the Spanish Government; nothing is done to protect their interests ; the interior is practically closed, and the Government will give no guarantee for the traders' safety. The interior is inhabited by the large Fan tribe. Some hilly country lies directly to the north of Bata.

January 17. - Went ashore and called upon the Governor. He was gracious and treated us to beer and then came down to the shore to wish us goodbye.

Bought some $40 \mathrm{lb}$. of dried fish, the principal subsistence given to the natives here. Messrs. Hatton and Cookson's are the principal English stores. 


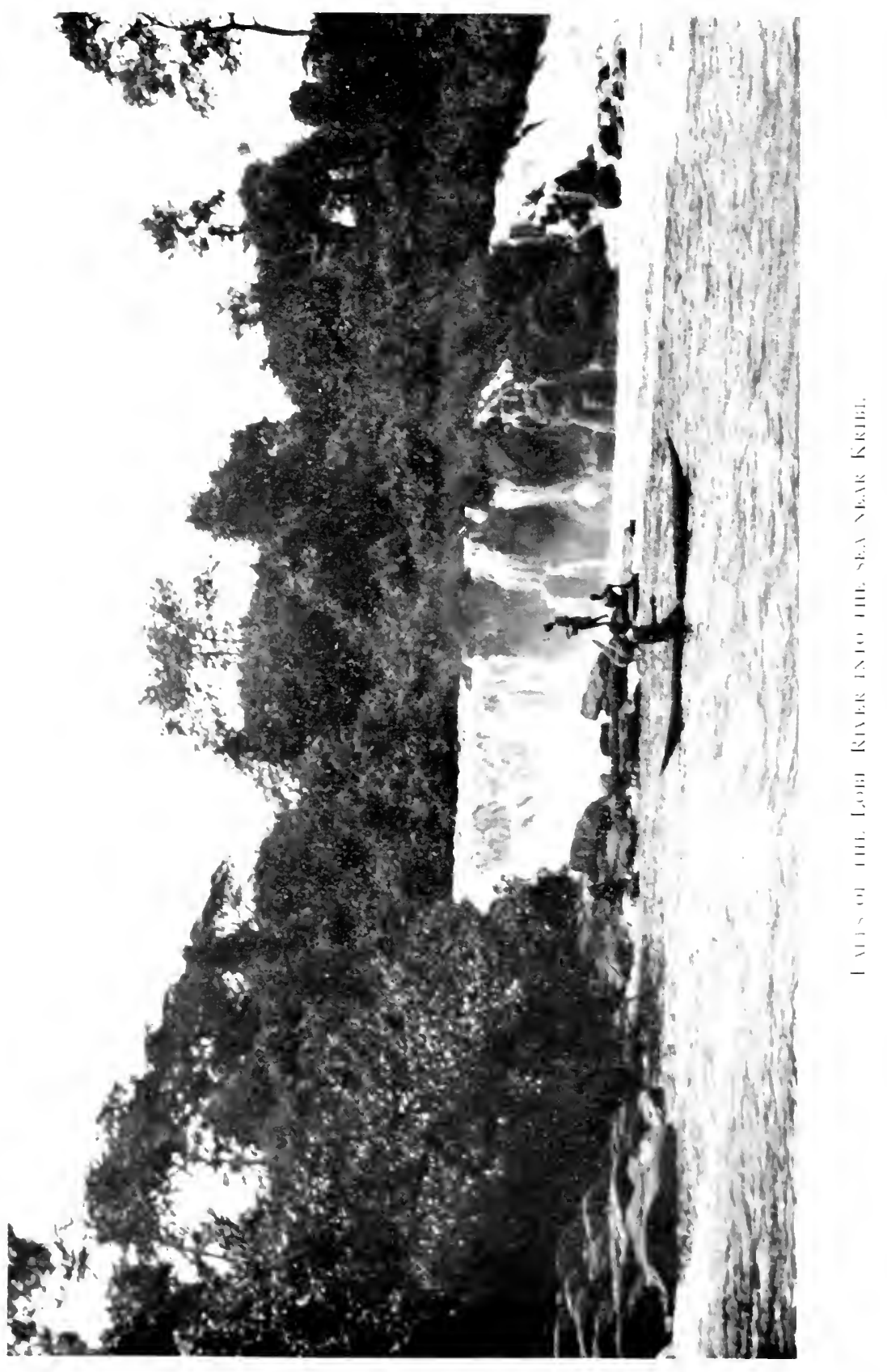



Towards four o'clock we reached a small port, consisting of nothing more than a store of Messrs. Hatton and Cookson's. From here we made a direct course to San Thomé, a distance of some 180 miles.

About 11.30 January 18.-Illha das Cubras came into sight. The Peak of San Thomé was not visible, but the whole island has a mountainous appearance, and is well wooded. Here and there on the higher slopes white buildings of cocoa farms arrest the eye. The town, which lines a semicircular bay, presents quite a pleasing aspect, the houses, of either wood or stone and roofed with red tiles, and some of the wooden ones painted white or a pale yellow, give a picturesque look to the town, which is not to be met with on the Coast. For with the exception of Axim and Cape Coast, which possess fine old Dutch castles, all the towns of the Coast have a remarkable sameness, with their rows and clusters of corrugated iron buildings and bungalows.

Elder, Dempster's agent, a Mr. Pilkington, came on board, and about 3 p.m. we both went ashore and he took me to see the Governor, who said he had already had intimation of my coming. My chief anxiety was to get my things passed through the Customs, and a letter authorising me to travel over the island, for much of the land is privately owned by cocoa planters. This was promised, but not without a great deal of talking, lasting quite half an hour. All might have been done in five minutes, but then I was dealing with Portuguese. Certainly they seem to have more "go" in them than the Spanish, whose dilatory methods are too irritating for words.

My next anxiety was to find a lodging for the night, and I did not much appreciate the dirty-looking hotel. I then rushed off at once to see Mr. Durrant, the head of the 
Telegraph Station, which is situated some ten minutes' walk from the town. In him I found a good Samaritan; he offered to put me up, and find a place to store my goods in. This gave me much satisfaction, as I had visions of having to store my things (and this was the Grovernor's suggestion) in the Customs. The latter arrangement would have led to endless bother, whenever I should want to take anything out. With the help of the carriers and a cart and mule we managed to move everything up to the Telegraph Station before dark. The traffic in the town is by mules; they look useful animals, and the carts are strong and serviceable. Everything in the town in the way of provisions is quite ruinous-5s. for a $1 \mathrm{lb}$. tin of meat, an egg $2 \mathrm{~d}$., bottle of whisky $10 \mathrm{~s}$, , gin 6s.- so I have distinctly scored in bringing my own provisions, and these passed free of duty.

January 19.- Stayed at the port to get things ready for a journey to the Peak. The Governor promised to let me have the letter by 5 p.m. yesterday, but, needless to say, it never arrived, and to-day the whole morning and afternoon passed without it; but Pilkington managed to wring the letter from his secretary towards evening.

January 20.-Left for Monte Café, a large roça, about 1,900 feet up, on the way to San Thomé Peak. There is a very good road all the way up, about nine feet wide, but on a steep incline. A little more than halfway is the village of Trinidade; another two hours from here brought us to Monte Café, a large roça, the houses and sheds being placed in the form of a quadrangle. Considering the hilly nature of the road, and that it was their first day's work, the Hausas did wonderfully well; but, with the exception of one or two of the Mendies, the remainder straggled badly. Taking him all round, there is nothing 


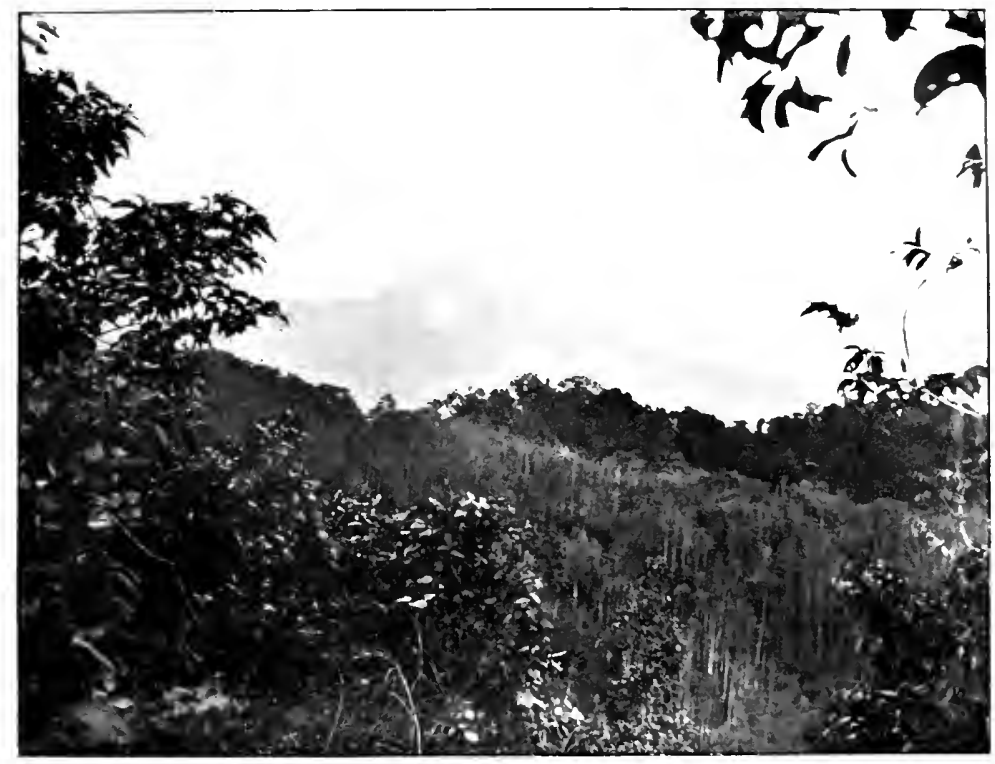

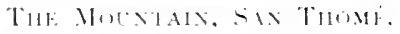

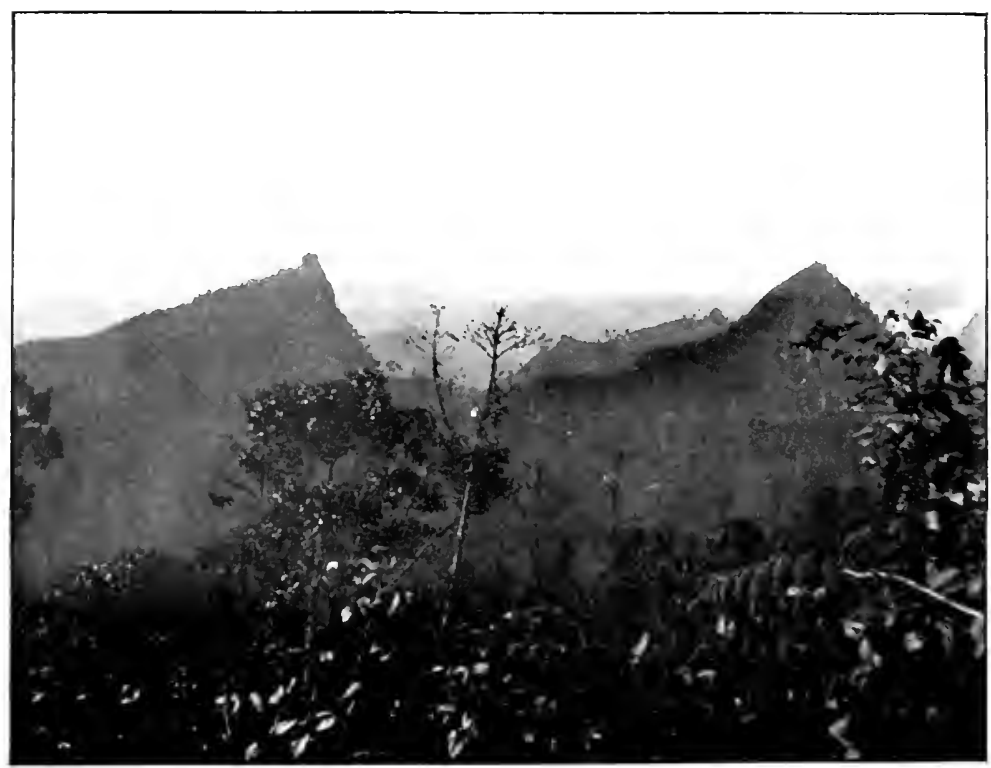

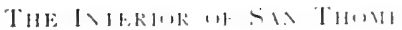



like the Hausa; he has a strong sense of duty, and makes the best of everything. They all feed together as if they had been friends all their lives. I arrived about twelve o'clock and found the acting manager, the manager, a Mr. Lucas, having gone to the Port. The former gave me luncheon, and José as well, and also fed the men.

About three o'clock the manager turned up and evidently looked upon me as another English spy. He said that he had no authority to allow me to stay here as the place was private property and belonged to a lady in Lisbon. I was somewhat taken aback at this, in the face of having shown him the Governor's letter. I at once gave orders to collect our things and we went off into the bush and camped. Upon this he changed his attitude, and begged me to stop, but I preferred to be independent. This was an occasion which showed how useful it is to have one's own carriers.

This roça is a very large one, something like nine hundred Angolas being employed on it. There is also a light railway in connection with the other plantations. While waiting for José at the roça, a large troupe of young children passed, presumably belonging to the labourers. I suppose these, in their turn, will become slaves. There is not a doubt that these Angolas never return. The farms are in such out-of-the-way spots, either perched on high hills or tucked away in some steep valley, that there is for them little chance of escape, and outrages could be perpetrated that would never come to light. It is perpetual slavery; every day is the same from 5.30 in the morning to six o'clock in the evening, with a short break at midday. And this is not all, for when the day's work is done, they have to go out to cut grass, and are to be seen toiling into the farms in the dusk with 
large bundles upon their backs. I got a good deal of information from an Angola born in the island; he was in charge of a farm close to Lake Amelia, where we camped. His father had been brought from Angola by force. He said: "I shall live and die here, like all my fellow-countrymen." The wages seem ridiculously small, 6s. a month for a man, and $4 \mathrm{~s}$. for a woman. Many young children are brought from Angola, and these are in their turn brought up to the slavery. The price given by the planters here for an adult slave varies from $£ 30$ to $£ 40$. This Angola told me that many of the labourers had fled the farms and were living in the forest, and were looting the bananas, \&c., for food. Each gang is in charge of a Portuguese, whose annual salary varies from $£ 60$ to $£ 80$. Six hundred to eight hundred slaves often arrive here at one time by the Portuguese steamers.

Above Monte Café the ground still rises to some 500 feet, forming the crest line which is seen from the port, and only at times is the top of the Peak of San Thomé just visible.

January 21.-Our first day's collecting did not produce much, but I got a pretty good idea of what was to be found, and I am afraid that it is doubtful if we get anything new. There is much cultivation even on the steep slopes of the hills, and practically there is very little of the virgin forest left. It is a wonderfully rich island. The soil is of a brownish red and is capable of producing anything. The whole way up from the Port to Monte Café are great cocoa plantations, while clumps of banana-trees, scattered palms, and tall forest trees give a wealth of verdure to the scenery. Near the coast the palm almost becomes the predominant growth. The oil is not exported, as a large amount is consumed on the roças, 
and this is even supplemented by a certain imported quantity.

Towards three o'clock the sky becomes overcast from the north, and occasional showers fall.

The manager of Monte Café has now quite mended his ways, and we have shaken hands. He has promised two mules for to-morrow, when we move our camp still higher up, to Lake Amelia, where there is a good deal of virgin forest.

While out to-day, I found a small puppy dog in the bush. I took compassion on him and brought him into camp. $\mathrm{He}$ is a sturdy-looking little beggar, and I shall call him San Thomé. This island is overrun with dogs of nearly every colour and description; it should be called the Isle of Dogs.

Jamuary 2.2.-Made an early start about 7 a.m. and arrived at a collection of huts near Lake Amelia about 9.30. It is a steep "pull-up" to this point, and almost an hour from Monte Café we entered thick forest with long-leaved plants forming part of the undergrowth. And there are gigantic cotton-trees, most of which present a weird appearance, for the cold, damp atmosphere has hung their branches with lank lichen growth that streams in the breeze like tresses of hair.

Lake Amelia is nearly 5,000 feet in altitude. It is about two hundred yards in circumference and has the appearance of having been a crater. Its formation is a deep bed, and the sides are clothed with thinstemmed trees rising in tiers. There is no water now, but only thick bog. At this altitude large clumps of bamboo are to be found; the coffee-tree does not seem to flourish, while the picturesque quinine-tree is in evidence. 
January 23-26.-Stayed and collected morning and evening, José always taking a different direction to mine. The forest growth, which at first looked so promising, yielded no ground thrushes such as Alethe, Callene, and Turdinus, and the localities were particularly silent, and we obtained nothing more than what is in Salvadore's list. 'There seemed to be quite an absence of insect life and hardly an ant was to be seen.

On more than one occasion I got to within 500 feet of the Peak, that is to say, on a level with the eye from neighbouring ridges, and I have my doubts whether it will be worth while to ascend it. The hill is not extensive enough and not high enough for the growth to alter. It is covered right up to its summit with the same forest trees that are to be found on the neighbouring hills, and one can hardly expect the fauna to be different, as it was in the case of the Fernando Po Peak.

It is a difficult country to work; the valleys, full of thick wood and tangle, are extraordinarily deep, and many are quite impossible to descend into, while water in the dry season is not plentiful. There has not been much rain, but generally towards six o'clock a dense cold mist from the south drives over the hills in thick clouds. It is very depressing, coming over in a moment of time, enveloping everything and blurring the trees to phantoms. Very often at sunset there are some fine colour effects, and on the 25th there was a particularly impressive one. Looking southward from my camp, a lofty ridge of wooded hills, jagged in outline, stood out in clear contrast to a thick layer of cumulus clouds directly behind, that had shaped themselves into the form of rugged hills and peaks, 
looking for all the world like snow-capped mountains against the wooded chain in the foreground, and this was further brought out into contrast by a dark leaden sky above.

Many of the smaller hills are cultivated, even the lower slopes in places of the Peak itself, giving the impression that every available bit of ground in this rich island is seized upon and made the most of.

The interior of the island has a peculiar geographical aspect; one looks down into a large and deep crater which practically forms the very centre of the island. Here the wealth of the island becomes apparent, for it has a very fertile aspect, with the foliage of the cocoa plantations, the coffee-trees, and the big clumps of bananas.

José is working very well and his skins have good form. And we have been lucky in the weather; bright, sunny mornings as a rule.

January 6.-Left for the Port so as to be in plenty of time for the Corisco. To my surprise I found that she had already been in, and had come from Annabon, and it was quite by accident that I met Sevrada in the town, who coolly informed me that it was impossible for the Corisco to take me to Annabon, and this after his promise to me at Fernando Po! I found that talking was no good, and I extracted from him another promise, and this was that I could go by the mail-boat leaving on the 23rd of next month, and a letter from him as woll giving me facilities at Annabon.

The weather here is still fine, in spite of its being the rainy season. A pleasant breeze always gets up from the south-east about ten o'clock and blows till about four o'clock. 
Our collection from the hills numbers fifty specimens in all.

February 4.-José left with the carriers for Zulma, a place about one and a half hours' walk south from here, where he is going to collect. In that neighbourhood the ground is chiefly owned by the San Thome natives. They are a poor people; all the good land has been taken from them, and they now only possess small plots of maize near the coast; their hovels are wretched, and their stock generally consists of a few fowls and a pig or two.

Religion with them is rather a superstition than a faith. Outside each hut a cross is set up, and these are often hung with offerings, a relic of former teachings that bade them offer up a prayer before the cross every morning on leaving their huts for the day's work.

Many of them are fishermen. It is a curious sight to see at night a fleet of canoes engaged in fishing. They advance in a long line, each boat carrying a flaring torch in the bow, the whole giving the appearence of a jetty lit up. The fire attracts the fish, which is then speared. The spearhead is fork-shaped with many prongs. The torch is about six feet long, and consists of dried palm leaves tied in a bundle.

José has a good camp, and I go out every day to see him, and shoot on the way.

February 11.-José down with dysentery symptoms. $\mathrm{He}$ is not careful enough about his water.

Have arranged with Pressler, a German trader here, to take me in his sinall steamer to Annabon for $£ 45$. We are to start on the 12th.

Have received no answer to my telegram to Sir Africa Jones sent on January 28th, asking him if the 
Batanga could land me at Annabon. She was due here on the 5th, but up till now has not turned up. I paid a reply, and it seems curious I should not have had an answer one way or the other. But I must not judge as yet; something may have happened that I do not know of.

February 12.-Jose arrived in from his camp, but is feeling off colour. During my stay at the Port I made my camp in front of the Telegraph Station, practically on the shore. I thought this was better. When one has a large camp, it is best to isolate it. Durrant, the chief superintendent, has been very kind, always insisting upon my lunching and dining with bim. José has something like forty-five specimens, including four examples of the rare owl, Strix thomensis, but I do not think there is anything new, unless it is one of the ground pigeons (Haplopelia).

Just now there is a great deal of sickness (blackwater) in San Thomé. One of the prominent citizens died of the disease a few days ago. It is now the worst season for health.

The cocoa trade here must be enormous. About a week ago over seventy thousand bags were waiting to be shipped; each bag represents about $120 \mathrm{lb}$. I should think it would pay Sir Alfred Jones well to run steamers here under the Portuguese flag.

On the night of the 11th we had a terrific storm with a great wind from the west. It lasted a good hour, during which time, even with the help of my two boys, I had hard work to keep my tent up. The tent presented to me by Burberry is in its main construction and texture excellent. Its chief recommendation is its extraordinary lightness, weighing about $50 \mathrm{lb}$. in all, while the colour is most restful to the eye. The material itself is very 
strong, but there are two faults-the pegs are much too small (one cannot beat the old ash peg), while the ropes are not of stout enough material.

I hear from Pressler that there is a Spanish boat from Annabon to Princes on the 19th. If this is correct, it will do me well, and if this fails, there is still the regular mail on the $28 \mathrm{th}$; but to speak the truth, I have not much faith in Spanish arrangements.

Left about 12.30 in ss. Tonga. The captain, Jorge Cardoso by name, seems a nice fellow. I asked him to have supper with me, but eventually had to put him off, José having another attack of dysentery symptoms, while my boy Bukare and several others were prostrated with sickness.

Before leaving I managed to get from the captain of the German boat Togo three bags of rice. The price on shore for the same would have been ruinous.

Induced José to take El Kossam. This medicine again had wonderful results. The next morning he was comparatively fit. I am very glad I brought some with me.

Had the opportunity of seeing the whole of San Thomés western coast. The island presents a mountainous and rugged appearance, and some of the peaks are very remarkable in their shape, especially the Dog Peak. It is like a gigantic obelisk, so regular in its contour that it is difficult to realise that Nature alone has carved it.

February 13.-About 9 a.m. the faint outline of Annabon came into sight, and we reached the island at eleven o'clock. The captain was evidently pleased at having struck his point so well. It was good work considering he only went by the compass and his log. 
He reckons the distance to Annabon from the Peak (San Thomé) to be 130 miles. He allowed eight knots to the eastward for the current. The rate of the Tonga is seven knots an hour.

Annabon is a volcanic rock rising abruptly out of the sea, and clothed with scrubby growth towards the top.

The white building of the Roman Catholic Mission, a little way above the beach and surrounded by palm growth, is the first to catch the eye. Then close to the shore itself, amongst a picturesque grove of cocoanuttrees, are rows of oblong huts containing all that Annabon can boast of in the way of inhabitants. They are all confined to this place. In the interior of the island, especially round the lake, casada farms and bananas are roughly cultivated, and these are visited at times. The inhabitants of the island number about 1,300 souls, and I don't think that I have ever seen a more nondescript-looking lot. It would be difficult from a racial point of view to place them. They have a kind disposition. My steamer was boarded by many of them; each one singled out one of my men and said he must be his chum during his stay on their island. Every day, when I was at the Lake, each would bring up food to his chum, and if he could not come himself, he would send a friend. They have marked negro features, with broad noses, and they are very bearded. Not a few. speak American-English, and hailed originally from the American schooners which many years ago used to visit this island for purposes of whale-fishing (before the Spanish occupation). There is a good deal of dysentery among the people.

The rainy season is from November to the beginning of June.

We anchored about twelve o'clock, and soon after a 
boat with a Sous Officier and a doctor came on board. It took little time for the former to inform me that he was the "Governor," and he was full of polite bows and scrapes when I presented him with my letter from Sevrada. After the usual lengthened conversation, which under any ordinary circumstances could have been done in a few minutes, it was arranged that I and José should at once go off in the ship's boat (taking with us all the baggage we could) to pay our respects to the Padres and arrange about our camp. The "Governor," of course, insisted on accompanying us, while the doctor was to remain behind and bring off my men and the rest of the baggage. We had scarcely got away more than a hundred yards when, to my annoyance, I saw the doctor rowing pellmell after us, his boat empty of loads. He was determined not to be late for the fair. I had had no sleep the night before, and the knowledge that a great deal had to be arranged before the night filled me with feelings of dismay, if not with anger, that I should find myself in Annabon, one of the most out-ofthe-way spots in the world, still a slave to convention. We found the Padres, at this time three, seated in their veranda ready to receive us. Directly I got into their presence I felt a kindlier atmosphere, and I longed to get rid of my two companions. None of them could speak either English or French, but a Sierra Leone boy who spoke very good English came to the rescue. The Father Superior, a charming personality, with splendid features and a flowing reddish beard, received me with open arms, and after a few minutes' conversation went straight to the subject at issue and showed me a store-room where I could keep any of my baggage should I require it, and said as far as he was concerned I could make my camp where I liked. 
I was then hauled off by the "Governor" and doctor to view their houses, which were full of dry-rot and creaking boards. The drink of hospitality was absent, but the doctor, in lieu thereof, gave me with much ceremony an effervescent saline, with which I drank the health of the King and Queen of Spain.

February 14.-Left at 6.30 a.m. for the Lake, which we took about three-quarters of an hour to reach. It is one of the most remarkable geographical features I have seen in Africa. After an ascent of some 1,300 feet one is suddenly confronted with a circular lake, about a mile in circumference. It is like the deep crater of a volcano, tall forest trees rising up in tiers all round it to a height of some 500 feet. The southern portion is the highest. Beyond, the ground begins to rise again till it attains a height of some 3,000 feet, forming a narrow watershed, and the whole way the ground falls steeply on both sides to the sea. It is thickly wooded, and this fact raised my hopes of getting a good collection, but after many fatiguing tramps the birds only represented the following species:-

Terpsiphone newtoni, Zosterops griscovirescens, Scops fea, Turturœna malherbei, Haplopelia hypolenca, Numida meliagris, Gallinula angulata, Anous stolidus. There is nothing more than these species.

The north side of the island is less thickly wooded; in fact, there are portions of open grass country interspersed with plots of casada and yam, grown by the natives. There is a fine orange on the island, large and with a thick skin, which peels off easily. It is rather bitter in taste. Towards evening I had a sharp attack of fever, which lasted until the following day. I had evidently got it at San Thomé, and it was of the blackwater type 
or tendency, with a temperature not higher than 102 and with pain in the region of the kidneys.

Directly the Padres heard of my sickness, they very kindly sent up some tinned milk and eggs.

The church here is a large one, and it took some eight years to build. The Padres in charge are two in number.

The inhabitants live chiefly on fish. There is a small colony called San Pedro, numbering about thirty people, on the south side of the island. The rows of oblong wooden huts of S. Antonio, ensconced in a thick grove of cocoanut-trees, is typical of those African villages one sees depicted in the older books of travel, those of Stanley, for example.

The island has poor soil, very stony and volcanic.

The inhabitants suffer a good deal from dysentery of a peculiar type, which in many cases continues for several years.

February 20.-The small Spanish steamer Annabon (100 tons) arrived, and we left by it the following day. Fare to Princes Island £35. Both the captain and purser were very obliging and fed us well.

February 22.-Arrived at San Thomé. Decided to pick up the rest of my baggage and not return. The question of expense and the fact that I am anxious to get to the Cameroon Peak before the rainy season commences decided me. Though I am short of one or two species from the island, I am convinced that a longer stay would not lead to any new discoveries.

On my arrival, I found that in my absence the Batanga had come in to take me to Annabon. Sir Alfred Jones had given instructions, but the agent at Duala omitted to let me know. Having waited for over two weeks and getting no reply to my wire, I chartered the Tonga. I don't think I am to blame in the matter. 
February 23.-Said goodbye to San Thomé, and was not sorry to do so.

February 24.-About 6.30 a.m. we anchored at Princes Island. The appearance of the island from the seaboard is very luxuriant; the banks clothed right down to the water's edge with thick forest growth.

Knowing Portuguese methods, I was glad to get off the Annabon about eight o'clock, as I felt sure I had a long day's work of petty interviews with officials before I was free to move, and I was not far wrong. First of all to my dismay I found that the Governor at San Thomé had omitted to inform the Governor here of my coming, and this after having promised me faithfully he would do so. The Governor lives here on a high promontory at the entrance of the harbour. I saw his secretary, who treated me in a most off-hand manner and kept me waiting at least half an hour pacing up and down in front of his house before he condescended to inform me that he had had no information about my expedition. The next thing I determined to do was to tackle the Governor himself. So I and José went off in the Telegraph Station boat to see him. I at once had a most agreeable impression of him-in fact, a sahib all over-and he showed much sympathy in my object. He at once wrote a letter to the Director of Customs to let my baggage through, but this fellow began to quibble about the term "baggage," and said that it did not include my stores, which was all "cargo" in his eyes, so I again had to send José off to the Governor to tell him of my situation. All this time the precious minutes were slipping by and I had visions of camping anywhere $I$ could in the dirty town. About three o'clock the Governor himself with his secretary came over, but apparently he had not much influence with the Director of Customs, who said he would never let my 
things go through unless he had instructions from the Governor of San Thomé. In the meantime the Governor had cabled to San Thomé for instructions, and shortly after the answer came that the expedition was recommended by the Government. But in spite of this, and the fact that I told him that all my baggage had been passed free of customs duty at San Thomé, that it was an understood privilege given to scientific expeditions, this little wretch refused to yield. Then another cable was dispatched to know if all my baggage could be passed free of duty. In the meantime I was allowed to take out just enough to allow me to make my camp outside the town, and it was none to soon, as it was past four o'clock, so we rushed off and made a camp on a road to a cocoa plantation just beyond the cemetery and about fifteen minutes' walk from the town. The cemetery is a most dismal-looking place, and full of broken-down and decayed crosses, and just outside the gate was a native body, wrapped in cloth, awaiting burial, presumably a wretched serviçal. This seems to be the method of burial, that of depositing the body at the gate for the caretaker of the cemetery to shovel into the ground; a small coffin containing a child was left in the same way the next day.

February 25.-I decided to wire myself about three o'clock. This had the effect of the Governor's sending instructions to let my baggage through.

February 26.-Busy all the morning sorting loads for a trip up country. I decided to leave the majority of provision boxes in the Customs. I found to my annoyance and disgust that the imp of a Customs House official had put all my cartridge boxes to get drenched by the heavy rain which fell yesterday evening, because he said they were explosives and so not safe to be left in the Customs. 
A large part of my stores, which I shall require to draw upon while I am away, I have left at the Telegraph Station. The Director, Mr. Hurdas, who is just now here on a visit of inspection (from here he goes to San Thomé), has been very kind and given me a store for my things. He is a very old "African." He comes out every afternoon to see me at my camp.

I am close to the Papagaio River, and it comes as rather a surprise considering the small size of the island. Where we are encamped it must be quite fifteen yards in width. There is not much water in it, presenting now the appearance of a Scottish burn.

Went with José to call upon the Director, Mons. Abrio, of the Esperanza Company, which owns a good slice of the island to our front, and therefore it will be necessary to get permission to shoot over the property. The English consul (a Spaniard) at San Thomé, by name Marin, has given me a letter of introduction to him. We found him in and quite ready to do everything for us.

He pressed me hard to take a room and enjoy comfortable meals with him, but I stood my ground at the risk of offending him, and he marvelled at my wanting to camp in the bush. But I have not come out to Africa to dwell behind brick walls. The old order has changed now and men who come out here cannot realise the old type of "African," who made his camp in the bush when and wherever the spirit moved him. As I write, my camp presents a delightful picture, a pretty spot almost surrounded by luxuriant wood, but here and there through openings in the trees towards the south one catches glimpses of mountainous hills, bathed in the wonderful blue which only distance can give. At varying distances from our two tents the men have constructed their rough huts of palm leaf, grouped, I might almost say, 
according to the races, the Hausas in one quarter, the Mendies in another, but all forming an outside ring to the tents, and then when night comes on each group of men sit cross-legged upon the ground round brightly burning log fires, all in merry mood-one perhaps amongst them holding forth to the others as a story-teller.

We made our camp not far below the roça. This roça is a large one with well-built houses-and a hospital attached. The sleeping quarters of the natives look rather like prison cells, each window being securely barred.

The working hours of the natives are from 6.30 with a break of half an hour at eight o'clock, then another of an hour at twelve o'clock, and then work is resumed till 5.30 p.m. I should call these rather long hours considering the climate and the amount of work usually got out of the native. The Portuguese themselves are hard workers and are always present with the men.

Our camp is close to good running water. The men have made some excellent huts, and the place looks more like a native settlement than a camp.

Two days' collecting gave us nearly all the known species here. Amongst the cocoa the ground pigeon ( $H$. principalis) was numerous and the Glossy Starling everywhere, but the bird which this island is most noted for is the Grey Parrot. Though still fairly numerous, this bird has no doubt decreased owing to the forest land being gradually converted into cocoa plantations, and the planters shoot a good many for eating. Kettlemans in his time out here (1867) reckoned them in thousands. Unless anything has been done since Salvadore's paper on the birds of this island in 1903 I have great hopes that this parrot is a new one. In its habits and manners of flight, $\& c .$, one would put it down to the West African species 
(Psittacus erithacus), and that is how I think it has escaped the attention of former naturalists who have visited this island. But when in the hand the bird presents a remarkable difference from the African species. The entire upper and under parts are very much darker; the feathers of the latter are edged with dark blue, which gives the appearance, when viewed in a certain light, of the body's being strongly marked with inky blue. All my men saw the difference at once. I propose to call this new species Psittacus princeps, though "neglectus" might be more suitable, but I feel for such a fine bird that the latter name is a little bit derogatory. We are collecting on an average fifteen birds a day, and José is working very well. This portion of the island is very well cultivated, but there are still a few patches here and there of forest growth. The fruit consists of bananas and oranges, which are rather sour, and avocados pears.

A great deal of land where we are has been cleared, that is to say, tall forest trees left here and there, but the ground underneath shorn of everything for the planting of cocoa, so the island in many parts has been bereft of its forestial beauty, which it must have possessed at one time. The steep valleys must have looked extremely rich when clothed in masses of tropical foliage, but now all is laid bare and the course of every stream can be traced.

This island is remarkably well watered; streams of sparkling clearness are found in nearly every valley.

The two big streams are the Papagaio and another corresponding to it which flows down the other side of the mountain into West Bay.

March 4.-Left to make a camp on a high ridgelike plateau close to the Peak. This ridge is very narrow and falls down abruptly to the north, and to the south 
one looks down into a steep valley, on the other side of which rises the big hill covered with thick forest growth.

By my aneroid the height of the ridge is about 1,800 feet.

Looking to the north, there is a splendid view over the greater portion of the island. I should say at least twothirds of it. The whole of this is undulating and thickly covered with trees, except where the wood has been thinned out for the cocoa plantations. The harbour is of remarkable form, cutting deep into the northern end of the island. I might liken it to the wide estuary of a river.

The remaining third of the island-the ridge where my camp is now, marking its northern boundary-is the mountainous portion of the island. Here there are one or two peaks of remarkable shape. Papagaio itself is like the top of a pepper caster. Here and there round its side the bare volcanic stone can be seen, too steep for tree growth, but everywhere else it is thickly clothed with trees. Then there is the Carriote, a bare pillar of stone, and a small edition of the Dog Peak on San Thomé. The island, however, is nothing like so mountainous as San Thomé, which is a mass of wooded hills and mountains.

Since we have been on the island there has been very little rain, now and again, sharp fall at night or early in the morning, or towards evening, and generally coming from the north. The atmosphere is rather close, except on the high ground, where there is always a breeze blowing, often stiffly, from the south. I should not say that this was at all an unhealthy island. Since I have been here I have been feeling remarkably well. It is now the rainy season, which lasts from September to May.

The thickly wooded nature of the mountain raised my 
hopes of getting some interesting species, including Turdus anthorhynchus, the thrush obtained by Fea, but my hopes were not be realised. I found wonderful forest growth on the hill; and though I had a path cut almost to the top of the hill to facilitate my collecting work, I was not rewarded. It was quite sad to find all this fine forest absolutely devoid of bird-life-nothing but silence or subdued tones everywhere.

However, our days up here have not been quite lost, for I have collected a pair of Lagonosticta, which I am almost certain will be new to science. This species is rare.

Being on such an elevated site I thought it would be a good opportunity to display two or three of my rockets. These are the same as I had on my last expedition. They are $1 \mathrm{lb}$. in weight and are made by Brock. They are very fine, shooting up a prodigious height into the sky with a broad trail of fire and then bursting with a terrific report that seems to shake the whole country.

As each burst in the air the men added to the effect by raising a war song. Several planters with whom I spoke afterwards said they thought it was a signal to the whole island that the Dowager Queen of Portugal was dead!

March 9.-Left for a large roça called Sundy, situated in the north of the island, and arrived there on the 10 th.

In this portion of the island there is much forest growth, that contains many swampy, sluggish streams, reminding me very much of the Congo forest. It is as silent as the grave and there is no bird life. There is a great deal of the tsetse-fly here (Glossina papxlis). The doctor at the roça tells me that it first came to the island some twenty years ago, and the mortality amongst the natives was at one time very great owing to the 
lack of supervision over natives already infected with the disease that were brought into the island. The fly is believed to have been brought by the wind from Gaboon. At present, owing to the more careful supervision (for every new hand that is now brought in from the Coast has his blood examined), the mortality has been much reduced. On this roça the average deathrate every year is now 2 per cent. The majority of the labourers here are from the Cape Verde Islands. They receive better treatment than the Angola, for the simple reason they will not be slave-driven. They generally get back home after their five years' term, and there are several here who are out again for the second time.

A good method which the Portuguese have here to lessen the $\mathrm{fly}$ is to make the men wear while working in the plantations a stiff, black canvas placard, like a sandwich board, upon their backs. This is smeared over with resin and palm-oil, and has the effect of attracting the flies, where they stick. It is a curious thing, but this fly seems to be attracted either by black or white, preferably the former. I have seen this myself when I have been reading a paper, which they have settled upon in preference to myself.

This island is being rapidly opened up with light tramways to all the plantations. Here they are constructing an electric one. This roça is one of the largest in the island, and has a good hospital with a doctor on the spot. The average amount of cocoa produced on the island in the year is 120,000 bags of $112 \mathrm{lb}$. each. The planters tell me they confidently hope to double this output when all the tram-lines are completed. Personally, I consider that Principe is far better opened up than San Thomé. Of course, the less mountainous character of the island makes it easier. 
The preparation of cocoa out here is as follows :-

The seed after being taken out of the pod is placed in large wooden trays which are covered over with a lid. Here it is allowed to ferment. Then when the process is completed this lid is taken off and the seed is allowed to bake in the sun. After this it is placed in a winnowing machine worked by hand, on the same principle, but on a small scale, as of our thrashing machine. This separates the husks and completes the preparation. The cocoa is then put in bags, ready for shipment.

March 17.-Left for West Bay, where there is another large roça. We passed through it, and made our camp a mile or so to the south. I had hopes of finding here the new thrush, T. anthorhynchus, found here by Fea; but constant searching in all the likely localities proved fruitless. I cannot help thinking there must be some mistake about this bird, or otherwise it must be a very rare species. Nor could we find the Wood Ibis (G. olivacens). It is probably migratory.

March 19.-Left by a short cut across the hills to our old camp, at the base of Papagaio. The road which we followed to cross the hills, though much overgrown, is a wonderful piece of road-making; the gradient is gentle and follows the contour of the hill. It must have been done when the island was first opened up many years ago. The Portuguese certainly excel in roadmaking; the tramways (often with deep cuttings) are quite admirable.

There has been much heavy rain lately.

March 22.-The Spanish boat Annabon arrived in the evening. She is taking us to Fernando Po. 
March 23.-Left our camp and arrived about two o'clock at the Port. Sent a telegram home, and also one to the Governor at Buea, asking him to give an order to the Customs at Victoria to pass our baggage.

I had my last fight with the Portuguese, and only got off by the skin of my teeth. The Customs officials have done all they can to worry me, and I had to pay 16,000 reis before they would allow me to embark. This was for Customs dues, \&c., which I ought to be exempted from, but they seemed determined to get something out of me, and they knew I had no time to appeal to the Governor.

On my arrival on board, the captain, who spoke broken English, was very rude to me, and said I had kept him waiting. But was it my fault? Setting aside the delay caused by the Portuguese, which had all the appearance of being done on purpose, the boat which had been lent to me by the clerk at the Telegraph Station was coolly commandeered in the absence of my men, who were engaged in getting my baggage from the Telegraph Station, by some Portuguese passengers, who took it off to their steamer lying in the harbour. It was only brought back by the steamer's launch after a delay of forty minutes. I am heartily glad to shake the Portuguese dust off my feet.

March 23.-A heavy tornado at night, but managed to sleep through it on deck. Towards six o'clock, March 24th, we came in sight of the southern portion of Fernando Po, and after the rain the Peak showed up very clear. It is a very imposing island. It seems little cultivated along the southern seaboard. With a little spare capital, I think it would not be half a bad venture to buy a cocoa farm here. Cocoa, however, has gone down a good deal in price. The labourers 
here receive three dollars a month. There is nothing to prevent one from "squatting" on the island. That is to say, cutting down virgin wood and planting cocoa. Then when the plantations are formed the Government steps in and measures the property, and a charge of $£ 1$ per hectare is made.

$\mathrm{Mr}$. Isaac, the manager of Holt's, was very obliging. $\mathrm{He}$ is Consular Agent here, and was able to get what I wanted passed through the Customs. He also made an arrangement with the Spanish Steamship Company to take me the next day to Victoria in their small launch, called the Gandi. All my baggage was accordingly transhipped from the Corisco on to the Gandi, but at the last moment the engines refused to work. This is typical of Spanish and Portuguese methods. However, the next day the Annabon arrived from Elobey, and she is to go to Victoria instead.

Made a camp in the Mango Avenue.

March 25.-Busy all day labelling and packing up skins.

March 26.-Very wet early morning. We struck camp about eleven o'clock, and went on board the Annabon, which left for Victoria at one o'clock. When close to Victoria a heavy tornado came on about eight o'clock. I was in bed on deck, and I had a pretty good wetting, and was glad when the morning came. Arrived about 8 a.m., and went ashore to the Ambas Bay Company, and saw there the acting manager, a German, Herr Clemen, who seemed ready to help me in every way. He put the Company's boat at my disposal. This was a great convenience, my stores being landed and taken straight to the store enclosure. I had no bother with the Customs, since instructions were sent from Buea 
that I was not to be bothered too much, and consequently only as nominal charge was put on whatever stores I took up country. It is refreshing to feel quit once more of the annoying methods of the Portuguese and Spanish. Having my own carriers, I was able to get on the road the same day, leaving Victoria about two o'clock, and after about two hours' travelling made a camp at a dirty little Bakwiri village. These people live under filthy conditions-pigs, cattle, dogs, and goats all share shelter with the owners.

The inhabitants could not make me out at first, but eventually came to the conclusion I was a missionary. In the evening, while I was having my supper, the young girls and boys came round me and entertained me with missionary hymns.

March 27.-Made an early start, and arrived at Buea about eleven o'clock. Altogether from Victoria the trek is about five hours along a good road, which ascends by gentle gradients. The altitude of Buea is 3,000 feet. On arriving $I$ went in search of the Acting Governor, Herr Hansen, and as luck would have it met him going to his office. He greeted me very graciously, and said my sudden:arrival had given him no chance to make any preparation. He sthen asked me to lunch. In the meantime I made a camp in the best place I could find among some rather rank grass just above the station proper. Just after pitching very heavy rain came on, which made me annoyingly late for luncheon with the Hansens. When I got there I looked more like a drowned rat than anything else, which caused much amusement to Frau Hansen and another lady, the wife of Herr Kirchoff, the Resident at Victoria. The Governor's house is a regal place, most solidly built, and decorated regardless of cost. I don't think 


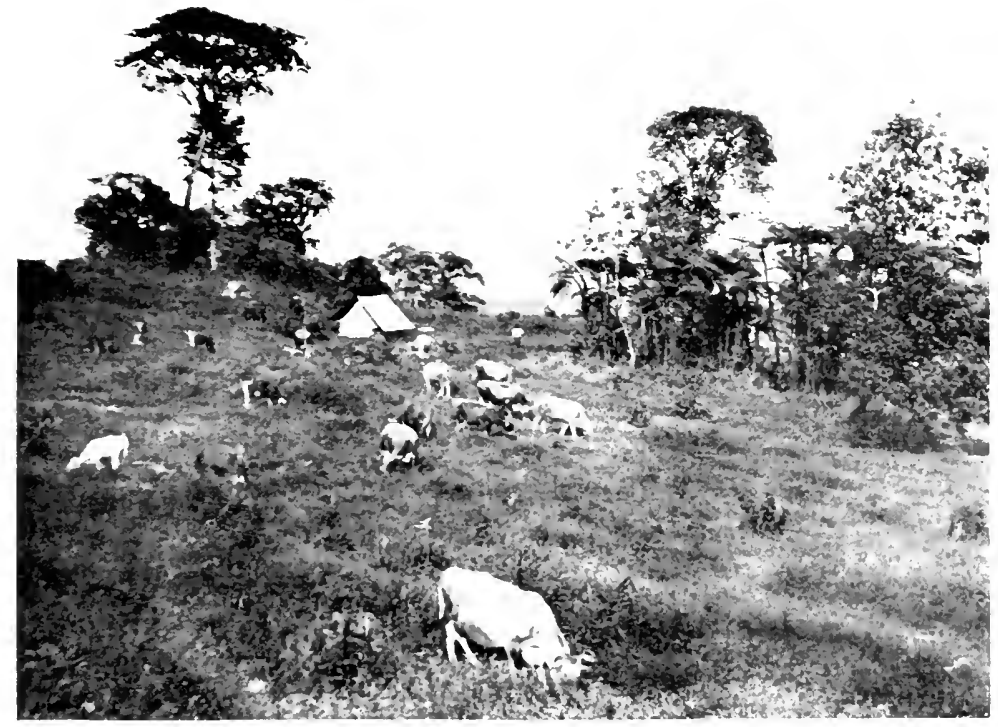

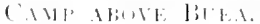

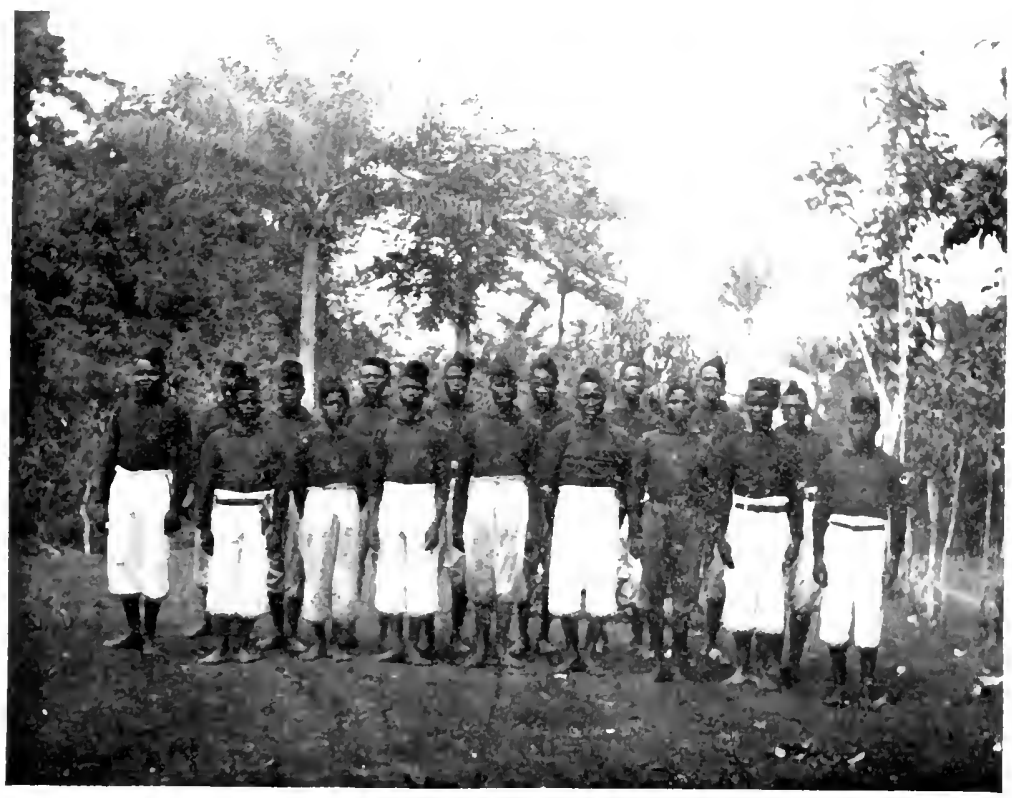

TH1. "IB, 

that any building in our West African colonies can hold a candle to it. Buea is quite a show station. All the buildings are well laid out and planned, and everything is in apple-pie order. There are something like 118 white officials and sixteen ladies. What they all do, God only knows! It must be a heavy drain on the home Government. I must say the Germans here have done nothing by halves. From a financial point of view it is another question. This love for exactness and order is really carried too far! To give an example: I had subsequently to go down from my camp to see the station-master. He was just dismissing some carriers. They started to leave, as I thought, as an orderly crowd, but they were all called back and made to walk in single file like soldiers. Every one here lives in the lap of luxury; there is a good dairy, where butter and cheese are made, and fresh milk, of course, is to be had every day. There is a fine herd of some sixty head of cattle. Every cow has a bell round her neck, and wherever the herd strays there is the agreeable sound of mountain music. To go back. Mrs. Hansen is a charming lady, and speaks English fluently. Her mother was Scottish. Frau Kirchoff, who is quite pretty, got mixed now and again, and lapsed into pidgin English. Nearly all the officials here speak English, or rather pidgin. They have to use it to talk to the boys, and even the soldiers are drilled in our language. It must be rather galling to them, and I suppose equally so to us, for this, by rights, should have been an English colony.

In the evening I dined with the Hansens. I broached the question of being able to get on to Yola after my work on the Mountain. Herr Hansen made no difficulty, and said I might go wherever I liked. 
March 28. Left for the Mountain. Except where the Germans have cleared above Buea for their cattle, the forest begins about a mile above the station. A two hours' strenuous pull through the forest in a north-west direction brought us to a clearing where a good bungalow has been built for the benefit of tired officials seeking the mountain air. I decided to work the forest from here, and made a camp just above the house. Thanks to some odd pieces of zinc sheeting, I was able to make a house for the men. They feel the cold a good deal, but I have sent down to Victoria for some more blankets. Since arriving at Victoria it has rained every day, which is unusual here at this time of the year. The rainy season does not commence till the end of June. We scarcely see anything of the sun up here. Depressing mists come over in great waves, shrouding up everything, blurring the trees to phantoms, and the shaggy tresses of lichen which stream from the boughs of many add to the weird effect. It is difficult under these conditions to get the skins to dry, and we have had to put the mammal skins over a wood fire.

The forest, which ascends to a height of something like 7,000 feet, is very dense, and consequently I find the collecting work very difficult. I lose on the average half of what I shoot. I am now employing the men in cutting paths in all directions, which I think will give me better chances.

Several missionaries have come up to see me here, both from the Basel Mission and the Baptist Mission. One is a particularly nice man, Herr Martens, of the latter Mission. He speaks English perfectly, and has been up several times to see me, and has also sent me fresh meat and vegetables.

I shall not make a daily record of my work $a_{t}$ 
Müssacka, one day is so very much like another. My task is to rise about 5.30, when my boy brings me a cup of coffee. After this I go out to collect, and generally come back about nine o'clock, when I have my first meal. José does the same. After breakfast he sets to work to skin and make up whatever has been shot. I go out again till midday, then have my luncheon, followed perhaps by a rest till two o'clock, when I go out till five. Then a warm bath comes as a refreshing relief, and afterwards I have a whisky and soda to set my brain cogs in motion, and then my diary is made up. My last meal is at 6.30, and it is never later than nine when I turn in. And so the days pass,

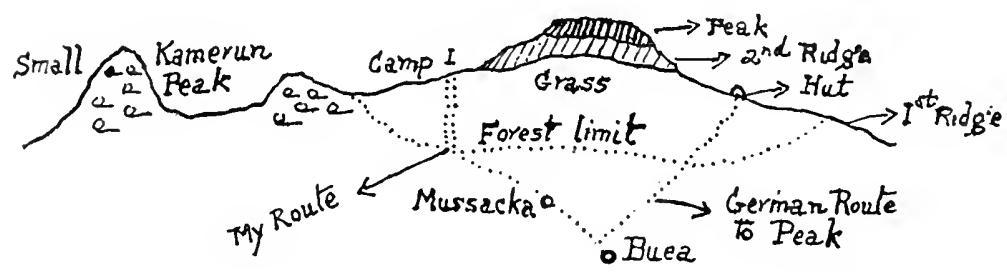

but they are always delightful, since I feel that I am in close touch with Nature. While I have been collecting, the men have made a road to the top of the first ridge, the most difficult part of the ascent, being the steepest. This took eight days. The Mountain is divided into three ridges. The first, above the forest, is grass-grown and scarred by deep channels and cavernous fissures. Between the first and second ridges the course lies over old lava beds interspersed with grass and a species of broom, a decorative shrub with small dark green leaves. I am sending some of the seed home. I think it would look well in the park.

On the top of the second ridge a small plateau, about three-quarters of a mile in width, runs up to the base of the Peak itself. 
A few nights ago a serious fray in the carriers' camp took place between the Mendies and Hausas. It originated in a single quarrel, one of the Mendies cursing the mother of a Hausa. To have his mother cursed is a grave insult even in the eyes of the black man. In cases of quarrels of this kind I always think it best to let them fight it out there and then. But the fight in question was so fierce that in a short time it became a party affair. A mad rush was made to the logs on the camp fire, and in a very short time cracks on skulls and the dull sound of body blows became general. It was with great difficulty that José and I were able at length to restore order.

April 15.-The road being completed, we made an early start for the Mountain with the intention of making a camp on the first ridge. All water had to be carried. The large water-carrier which I got at Silver's came in very useful. All the loads, of course, had to be very light. I had five white flags placed up the track at intervals. When the mountain is clear they can be seen from Buea.

Three days ago a wonderful rainbow of the most brilliant colouring appeared towards evening in the south. After the excessive rains of the past fortnight one could not help being reminded of the story of Noah and the Ark, to hope that it was the sign of better weather to come. It is generally towards evening and the early morning that the hill is visible, and then it is that a fine panoramic view of the land below can be obtained. The Cameroon River and its many creeks intersecting a well-wooded country show out sharp and clear. To look down upon the clouds is wonderful; masses of soft, billowy vapour lie over the land below like a rich canopy, and so opaque that one feels that 
to jump down would only be to bury oneself in a great bed of wool.

The ascent was successfully accomplished to the first ridge, which is about 8,000 feet. Here I rnade a camp. The actual time from Müssacka was an hour and twentyfive minutes.

All the men, with the exception of the two gun boys, Mama and Wigga, the cook boy, John, and the cook's mate, Thomas, left again for Müssacka, as the nights were pretty cold.*

April 16.-Went out collecting and found the following three species, which I think will be new ones. An anthus, which frequents the grass-covered portions of the hill. It is shy, and flies when disturbed to perch on boulders. On my trial trip to the Peak, which was on Easter Sunday, when I reached the base of the Peak I observed this species. The other two species were a Weaver finch and a Saxicola. The former was in small flocks.

The western portion of the Mountain has much less lava beds and more of grass land. Looking due west from the camp, about three miles distant, one sees the wood creeping up to a small peak, and directly behind this the small Kamerun Peak, which is also thickly wooded.

April 17.-Left to ascend the Peak, and reached the summit at two o'clock, the actual ascent taking one hour and fifty minutes. At the base of the Peak there are old lava beds, where the stones are now thickly coated with a greenish lichen. A pretty red heather also is to be found growing in thick bunches. In the last portion of the

* In the early morning, 6.30 to seven o'clock, the average maximum temperature was 50 and the minimum 40 , and the cold was intensified by a stiff wind from the east. 
ascent one sinks ankle-deep in fine ashes. The summit is a most forbidding-looking place, nothing more than a series of deep craters, or vast ash-pits would better describe them. There are at least five of these, and they are so fresh-looking that the ash might have been thrown up but yesterday. There are no weeds nor grass to tell their age, but here and there grow large tufts of a spongy, dark green moss. It was pretty cold, with a maximum temperature of 55 and minimum 50 (2.30 p.m.). Continual mists kept passing over us, but now and again the sun would part them and disclose to view the mountain land below us, and even the blurr of distant forest land beyond. We succeeded in creeping up to the highest point, which terminates in a kind of promontory, and is actually the rim of a very deep crater where the lava has made its exit. I felt dizzy, and so had to lie upon my stomach to take a photograph of the land below, which showed a picturesque group of grass-covered mounds, or, rather, extinct craters, lying to the west. The afternoon light, playing over them in waves, lent them a plushy appearance. These mounds gave me a very good idea of the formation of a crater; some of them were mere shells, as if the whole of their centres had been scooped out from one side. At the base of the Peak the Germans have built a small tin house. In it I found a somewhat dilapidated book containing the names of those who have climbed the Peak, but several of the pages had been torn out, and I looked in vain for that of Mary Kingsley. At Buea I was told by a German officer that he had seen it in the book. It must therefore have been torn out. It is a great shame. She is the only woman who has ever climbed the Peak. She must have been a woman of exceptional strength, for it is a climb that taxes the powers of the strongest. 
After a rather trying descent, and I always think that it is much worse than the ascent, we reached our camp with a feeling of satisfaction that one of the objects of the expedition had been accomplished.

April 18.-I and José left to try and gain the small Kamerun Peak by following the first ridge in a due westerly direction, but it turned out to be farther off than it looked. After a two hours' trudge we gained a wooded ravine. On the other side of this the forest growth crept up the hill to cover the first small peak, which I have already mentioned. The trees in this ravine were of scarecrow appearance, which was accentuated by the long tresses of lichen streaming from their limbs. Amongst the undergrowth I came across blackberries, in colour a pale red, but with the old familiar taste, reminding one of breezy commons and snug hedgerows at home.

I noticed no different species of birds from what I had already obtained in the forest below. After luncheon we left to return, but the end of an enjoyable day was unfortunately marred before we could reach Müssacka by drenching rain. However, I feel I ought not to complain, for we have had on the whole splendid days since the appearance of the rainbow.

April 23.-Herr Martens, of the Baptist Mission, has kindly sent me up one of the Buea hunters to help me to finish the collecting here, especially to try and obtain a rare Francolin, which seems to keep entirely to the forest growth above our camp. Often towards sundown we hear its loud cry in some steep valley above us. I feel convinced the bird is different from that found about Buea. The hunter, who knows a good deal about the animals and birds of these parts, is of the same opinion. 
He turns out to be the hunter employed by Herr Hansen, but as the latter is away from Buea I don't think there will be any objection to my employing him. He speaks good English, and promises to get all the "small fowl" he can for me. He is an evil-looking person. His right eye has at one time been injured, and the lower lid hangs down all bloodshot, and water is frequently streaming from it. His face, too, has numerous scars, which look very much like old burns. He wears a dilapidated black hat of Guy Fawkes shape. The rest of his clothes, misfits of the most gross kind and much torn, are almost as sombre. His only companion is an apology for a dog, one of the leanest pariahs I have ever seen, but his master is loud in praises of his hunting qualities.

In spite of this bad picture there is a kindly look in his one good eye that tends at once to dispel the first bad impression.

April 24.-The hunter left early with one of my 12-bores, and came back about midday with the bush fowl I wanted. It is a remarkable species, and I think it will be new to science. In the meantime the men are making a path with the idea of reaching the small Kamerun Peak. It runs along the edge of the forest growth before the grass is reached.

The collecting is going on well. Several of my Fernando Po species, or I hope their near allies, have turned up. These belong to the genera Lioptilus, Nesocharis, Dryoscopus, Hapaloderma, Smithornis, Cinnyris, and Cryptolopha, and within the last day or two I have, as it were, struck a new vein in birdlife here, and that is in the forest at an altitude of about 4,000 feet. As soon as the road to the small hill is made I shall leave Müssacka and make a camp in the forest to work the ground at this altitude. 
April 26.-A fine day, and the road having been finished, I and José started for the small hill, which we reached after a climb of an hour and forty minutes. I shall have to give up the idea of exploring the small Kamerun Peak; it is too far off, and the making of a road would take up too much time.

At the top of the hill we obtained a fine view of the Fernando Po Peak. My aneroid recorded 8,000 feet. After our midday meal we left.

In the evening, while sitting in my tent after supper, I had a suspicion that the ground underneath my chair shook. This was at eight o'clock. It was ever so little, but enough to make me call José, who at once confirmed my suspicion. Half an hour later another shock came, and after this at intervals of five to ten minutes there were more, and increasing in violence. The night was very dark, and this added to the terror, if anything. At each great boom from the Mountain above us the earth beneath us shook like a live thing. Shock after shock came and went, to die away in the forest below us. Torrents of stones poured down the hill within half a mile of our camp; forest trees kept crashing down and breaking in two like matchsticks, and the cries of terrified monkeys fleeing before the torrent added more horror, if that were possible, to the dreadful scene, while in the intervals of silence we could hear far below us the hymns from a Mission going up for protection. I stuck to it as long as I could in the hope that things would improve, but they only grew worse, and at three o'clock in the morning I sounded the retreat, and this lasted over two hours in torrential rain through the thick forest. I had the intention of camping on a spot which I had already cleared for my next camp, not very far from where the forest begins above Buea. On reaching this place 
I sent back the men to bring down the remainder of my loads. On coming down they reported to me that they had hardly left the old camp when showers of stones came down and covered the place. This was a narrow escape!

In the meantime the ground which I had cleared seemed so unsafe that I decided to go still farther down and make a camp near the station farm. This we did about seven o'clock. With the exception of two or three white officials, every one at Buea had fled to Victoria, and then on to Duala.

Altogether, during the first night of the earthquake, over one hundred shocks were felt at Buea, and there were numerous severe shocks throughout the day of the 27th.*

It was extremely fortunate that our work was practically finished when the earthquake happened, and I mean to leave now for Bituti, a small Bakwiri village about two hours from Victoria, so that José can go down and send off the collections by an English steamer which is daily expected. And also I think that it would be foolhardy to stay anywhere near the forest while these shocks are going on. To ensure the boxes being in time, I made a night march and reached Bituti about midnight. This is a filthy little village; it would be difficult to find a more dirty race in Africa than the Bakwiri. They all live together with their pigs, sheep, and goats. These they seldom part with, since they keep them for sacrificial rites. When a chief dies pigs, sheep, \&c, are killed and placed in the grave of the dead man. The numbers vary according to the importance of the deceased; sometimes as many as forty are killed. A funeral of a chief in the neighbouring village took place the next day. All the people of Bituti left, the majority carrying small pigs. * The shocks continued on and off till May 11th.-AutHor. 
Though the Governor has forbidden these sacrifices, I feel convinced they still go on, for in the evening the people returned from the funeral without their pigs and sheep.

April 28.-José left for Victoria to await the steamer. I shall be able to send off five boxes of skins, including the island collections and the first portion of the Kamerun Mountain collection.*

Had a most annoying thing happen to-day. The man who should have been looking after the remainder of the skins drying, left for some reason or other. In the meantime, one of the numerous pigs roaming about the village made off with three of the skins, which included a specimen of the rare Francolin which I obtained on the hill. The man has been sad ever since, for I fined him $£ 5$. As for the pig, I hope his dose of arsenical soap has not improved his interior.

At about seven in the evening the first appearance of fire on the hill was visible, a rich red glow on the east side of the mountain. This must be the larva coming down. It put the finishing stroke to the general panic prevailing in the neighbourhood. This little village is quite close to the road to Victoria, and all night long streams of terrified natives carrying on their backs all their belongings, and crying out, "The fire is coming! The fire is coming!" crowded down the road. At Victoria nothing less than a panic prevailed. The Government ceased to exist; every

* Sad to tell 1--one of these boxes never reached England. Boyd was in the habit of using his empty store cases for sending his skins back home, and in this instance it happened to be an ammunition box, and he forgot to obliterate the word "explosives" upon the lid. It was, therefore, not allowed in the hold of the vessel, but was kept on deck, and owing to the lightness of its contents it was washed overboard in a storm.-ED. 
official had left either for Duala or for a steamer lying in the harbour. Thousands of natives, with their boxes, spent the night on the beach, while the stronger had taken possession of all the boats.

The older natives, who could remember a former eruption which occurred thirty-nine years ago, showed less anxiety.

April 29.-José arrived back. He had sent the boxes off by the Axim, which came in yesterday. Altogether, the number of skins sent off were 187 from the Mountain.

May 1.--Returned, and made a camp near Sopo. The Commandant of the barracks just below this place has asked me not to go to the hill again till the Governor, Herr Hansen, is back.

May 3.- We have instituted football amongst the men. José has just got a ball from home. The men play uncommonly well, and show much spirit in the game. It is a capital thing for them.

May 4.-I had a very kind letter from Mr. Martens, asking me whether I would like to accompany him and several other missionaries to the burning crater. I have accepted.

Herr Hansen has returned, and has given me permission to make a camp above Buea. I shall leave José to do this in my absence.

It is amusing, but all the natives here say that I am responsible for the earthquake; that $I$ went up to the Peak, and fired my gun into the crater, moving to wrath the devil that dwells therein! This devil, in their imagination, is half-man, half-beast, and is one-eyed, and the grass upon the mountain's sides is the hair that hangs from his limbs. 
The old hunter came down this afternoon, pulling a very long face, saying that the chief of his village was " making palaver for him," because he had helped to rouse the devil with the Englishman.

I have already described this hunter, and his somewhat evil appearance certainly makes the tale more picturesque.

May 5.-Left for a Bakwiri village called Ekunolelu, where we shall sleep prior to ascending the hill to see the crater. Our party consists of four missionaries-the Revs. Martens, Gutbrod, Wahl, and Rodt; the three latter are from the Basel Mission. I must say these missionaries are true explorers at heart, and they seem to know more about the country and the people than all the officials put together.

The Basel Mission has something like 150 boys.

The Government gives them a good deal of power, and I fancy it looks to their schools for teaching the rising generation of natives the German language, and so gradually rooting out the pidgin English. It is really surprising how extensively spoken the latter is. Our influence before the German occupation of the country must have been great. During the first two hours we passed numerous Bakwiri villages, and after that the road led through deep forest. It was a via dolorosa, as it passed over a very extensive larva bed. We arrived at Ekunolelu about four o'clock. From here we could see a great volume of smoke coming up from the crater. And here we had a very novel experience, that of having to buy water. There is no spring water, and the natives have to rely entirely on the rainfall, which they catch in pots placed under the eaves of their houses. All the young men and women turned out to sell us bottles of water, which we bought at the rate of a leaf of tobacco 
or a penny a bottle. Nearly all the Bakwiri towns along this road live under the same waterless conditions. I might describe them as being situated on the first elevation above the low land, with the higher slopes of the Mountain behind them. There is not a doubt that these people were once down below, but owing to persecution were driven up to their present position. I do not think they would have willingly chosen a position without water.

May 6. - We made an early start before light, about four o'clock. For one and a half hours the road led through forest, debouching at length on to the grass portion of the Mountain, where it was overgrown at first with scrub. Another half-hour brought us on to open grass-land, broken up by ridges, and here and there craters, and the mounds of extinct volcanoes. We were now within about one thousand yards of the eastern edge of the Mountain, and the general direction of the road was three hundred degrees.

About a mile from the crater, which was hidden behind several lofty extinct craters, loud crashing reports were heard at intervals, followed by dense volumes of smoke. A feeling of eagerness to be there caught hold of us, and we pressed forward, till at length, on gaining the summit of a high mound, we came within full view of the two burning craters not more than three hundred yards away from us.

The position could not have been better for watching the action of the craters. A small valley, or rather an old lava bed overgrown here and there with a few scraggy bush trees and not more than two hundred and fifty yards in width, intervened.

The two craters are situated in the narrowest portion of the valley. On the left, towards the north, is the base of a range of extinct craters that practically runs down 
from the Peak. On the right is the wall of a large extinct crater, now grass-covered.

The larger crater was at this time not more than thirty feet in height, and a hollow mound of black cinder, from the top of which dense volumes of smoke issued. The scene baffles description. Red-hot stones were being belched out, immediately followed by appalling detona-

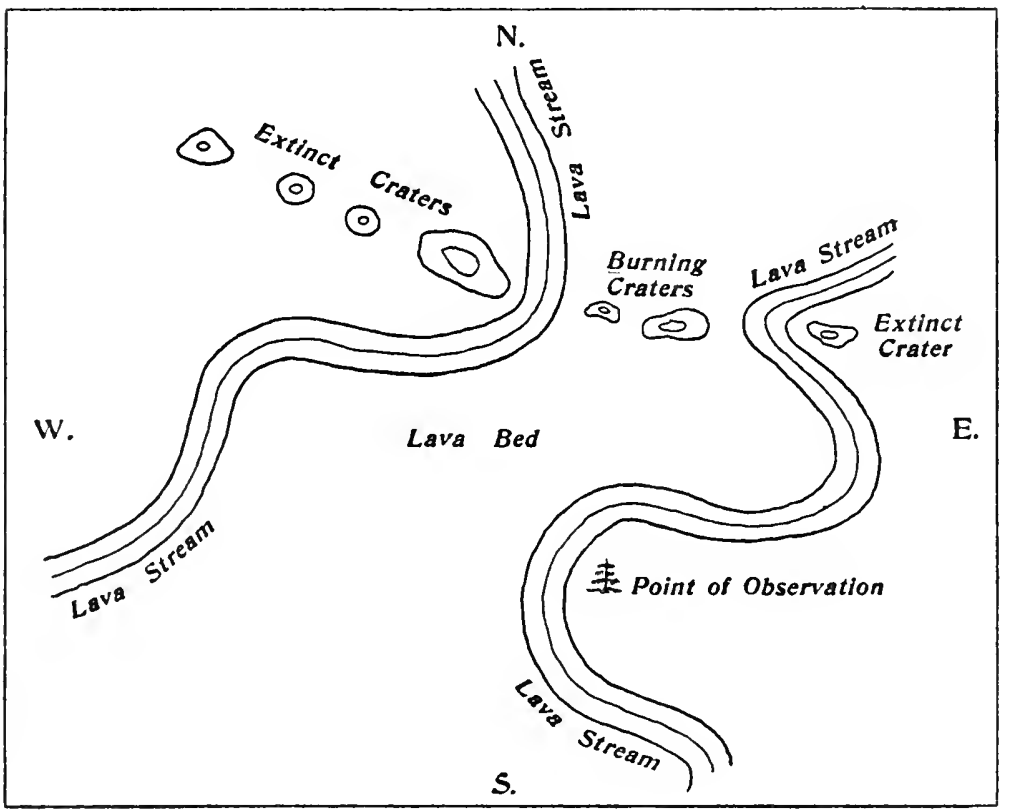

tions, like the roar of many cannon; then more volumes of smoke were thrown up, and stones of great size were hurled into the air till they became mere specks in the sky.

But the small crater was much the more appalling and vicious of the two. It was only about four feet in height, looking like a small mound encircling the front of an exaggerated camp oven. There was scarcely any smoke, which in the case of the larger crater seemed to point 
to its having less force. Masses of flames, with red-hot stones, were shooting up, accompanied by crashing reports. It was just as if hundreds of pieces of iron were thrown up in to the air straight from a blacksmith's furnace.

We managed to get a good view of the lava stream of the big crater by creeping round on the ridge of the extinct crater on the right. A scene of appalling desolation met our eyes. The lava bed, which was something like seventy yards in width and still smoking, had made its way through a well-defined valley, and according to native reports had reached a small village called Lisoko, about two hours' distance from the crater. Everything on either side of the stream had been scorched and burned to death, and amid the desolation trunks and limbs of solitary trees stood out like twisted iron.

I took twenty-eight photographs altogether, which I hope will turn out well. We could not have had a better day; there was no mist.

After some cold tea and slices of ham, supplied by the missionaries, we left again for Ekunolelu, which we reached at four o'clock, feeling thirsty and exhausted. Bottles of water were quickly bought, and as quickly emptied, regardless of colour. On the way down we heard the crying of several baby chimpanzees. They are to be found in the forest on the south-eastern ridge of the Mountain.

May 7.-Left for Buea, and arrived there about ten o'clock. On the night of the 6th several severe shocks were felt at Buea. We did not feel them at Ekunolelu. I feel certain that the new craters are intimately connected with the Peak and the portion of the Mountain opposite to Buea.

In the evening, about 7.30 , the bright glow of fire 
lit up the Mountain to the north-east. This probably indicates a further flow of lava.

May 8.-Busy all day writing letters: to father, to O. M., and to Dr. Keltie, giving him a description of the earthquake and the approximate position of the two craters.

May 9.--Shifted our camp close to the edge of the forest, and near a beautiful clump of tree ferns, which at once lent no ordinary aspect to our camp. Close to the clump there is a leaning tree with shade-giving leaves. Here I sit, have my meals, and do my writing. To the south there is always a fine panoramic view to be obtained, the whole country mapped out below one, and then the sea beyond. I think one should always try to choose a picturesque spot for one's camp, it tends to stimulate the brain, and this is good when one has writing to do. My chief object is to work the lowest portion of the forest, and then start for the Manenguba range.

May 10.-Busy collecting. Have given one of my collecting guns to the hunter, as he knocks small birds all to pieces with the 12-bore.

May 11.-The hunter brought in a Trogon and a Smithornis, which he found on the east side of the hill. I hope these will be new. At 6.45 this evening there is a fire effect to the east. This is probably the lava of the small crater coming down.

May 14.-Left with José to see the craters again, and with the object of making a route sketch so as to fix the position of the craters.

The hunter, with gun and dog, accompanied me as an interpreter. His rig-out for the occasion was won- 
derful-a white helmet of soldier pattern, a white coat with brass buttons, trousers of chess-board pattern, leggings, and boots that had the look of brown paper. As the sun got up, and the road became more hilly, he began gradually to shed his fine feathers; first his leggings were slung to the muzzle of his gun, and then his coat was thrown to his boy, who trotted behind him.

Arrived at Ekunolelu at twelve o'clock in drenching rain. I make the distance from Buea just ten miles, which agrees very well with existing maps.

May 15.-Made an early start, and reached the burning crater about eleven o'clock. The hunter was the last to come up, looking disconsolate, for his boots had succumbed to the knife-like stones of the old lava beds over which we had to pass. "Massa, massa, dem boots done finish!"

I made the distance to the crater from Ekunolelu four miles. Towards the end it was impossible to pace, so I had to judge the distance. The crater had assumed much bigger proportions, as can be seen by comparing the photographs which were taken a few days ago. They were taken a few days previous to my last visit by Mr. Kestler, of the Basel Mission. He very kindly gave me these two copies. The crater made a magnificent display, and having gained strength the stones thrown up were of enormous size; masses of flame soared up, followed by terrific reports. The height must now be quite sixty feet and the diameter seventy feet to eighty feet. It was a new aspect of the crater to see that the side where the lava had flowed had broken down, and that the smaller crater had practically been swallowed up by the larger, but the lava of the former had gone down in a different direction, showing a bearing of 300 degrees. The hunter stood for a while dumb at the sight, with 


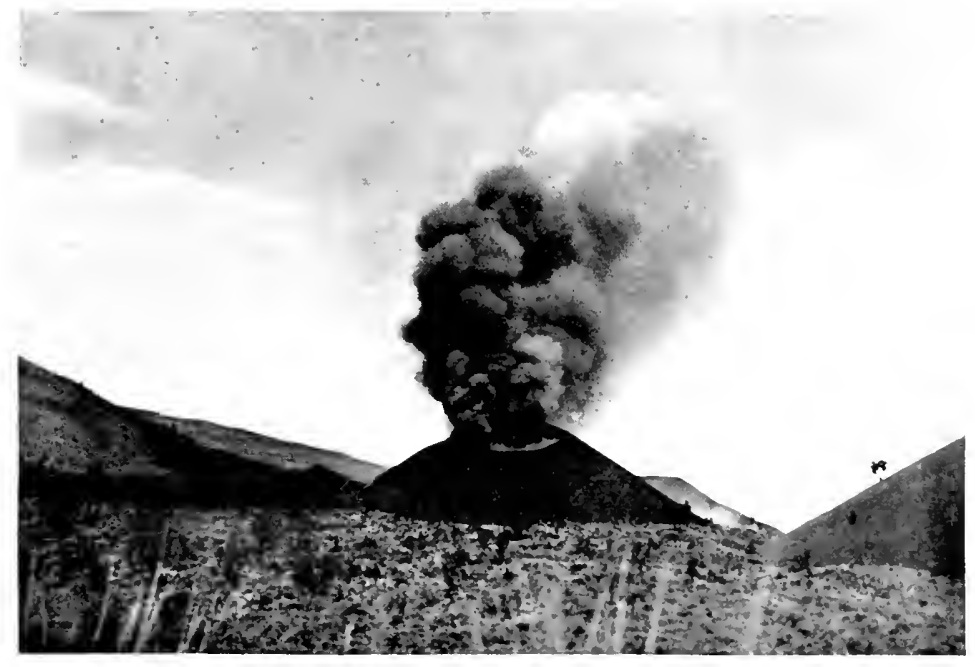

THE CRATER IX ERUPTON.

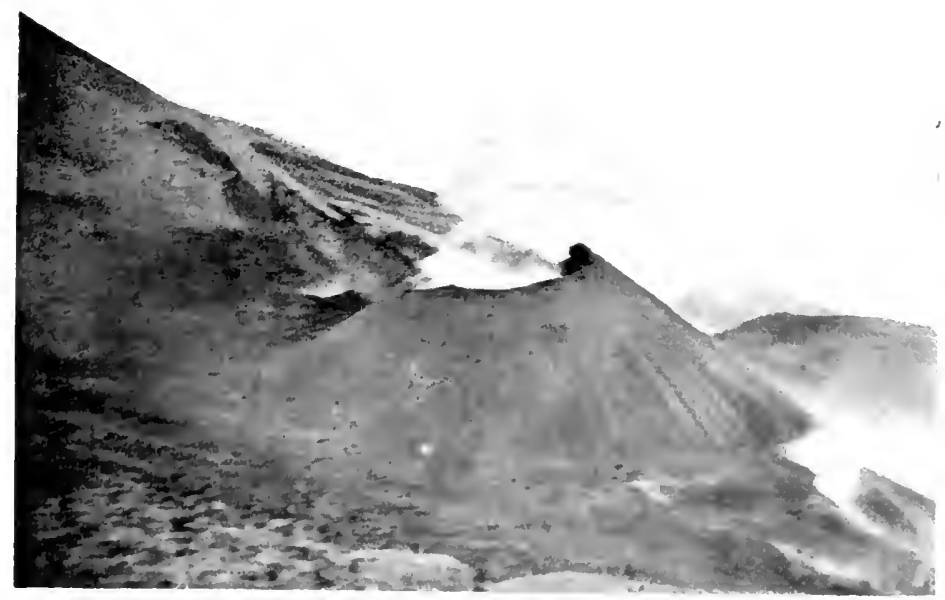

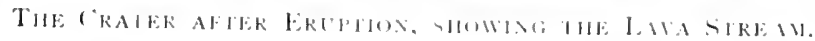



his hand covering his open mouth; then he exclaimed, "Massa, dem devul shoot plenty, he no fit tere!" It is wonderful to think that this is going on day and night without intermission.

We tried to get round to see the lava, but the increased firing range of the crater prevented us. However, we got so close that red-hot stones fell a few feet from us. It is an interesting fact that the stones were red-hot when they left the crater, yet we were able to pick them up so soon as they touched the ground; they were only just warm. The material of the stones is of the nature of pumice, and no doubt this accounts for its parting with the heat so rapidly.

After lunch I took another set of photographs, and then we left and gained a path across the Mountain to Bomakandi, a village we had previously passed on the road to Ekunolelu and about two hours from Buea.

May 16.-Arrived back in camp.

May 17.-Left for Victoria to settle up things finally with the Ambas Bay Company. Took with me another box of sixty-seven skins to be sent off by the next English mail. Before leaving I wrote to Herr Hansen, saying that I had fixed the position of the new crater and its approximate height by aneroid, and asking for the honour of calling it the Hansen crater.

May 18.--Settled up everything at Victoria satisfactorily, and gave over the box of skins to a Mr. Hewitt, an assistant in the Ambas Company, to send off by the Olenda, which is expected in on the 21st. Also $£ 3$ to cover expenses, including a cable to Cranbrook asking for the box to be met. Drew from the Company $£ 60$

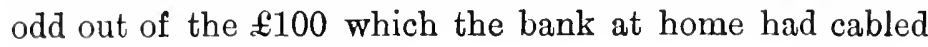
to the bank at Lagos. 
On my arrival in camp I found a letter from Frau Hansen asking me to dinner on the 20th.

May 19.-Busy all day packing up loads, as I intend to leave for Albrechtshöhe (Kumba) on the 21st. I am getting twenty-three local carriers from the station-master here, as far as Kumba. Rate, 6d. per day and 1d. chop money-a great improvement on our exorbitant tariff.

May 20.-Dined with the Hansens, who were alone. The earthquake formed a great topic of conversation. During dinner Frau Hansen brought up the question of my proposing a name for the new crater, opposing with the feeble excuse that it had a name already, the Mier crater (the Mier crater is quite two miles from the new one; my hunter pointed it out to me on my way back to Bomakandi). This showed me that, if there were no other reason for their attitude, then they must have been ignorant of my past record. In response, therefore, I told them casually that I held two gold medals for my work in Africa, one from London and the other from Antwerp. After all, it was not a very big thing to have asked, and my desire was to show him my appreciation of his hospitality and kindness to me. I am certain that I am the first to fix the position and height of this new crater.

May 21.-Left Buea at 8 a.m. with forty-three carriers in all, the column numbering forty-seven. Before leaving I had a small breakfast at Basel Mission and many kind words of farewell from them on departure.

For the first three hours the road passes through nothing but cocoa plantations. A six-hours' march brought us to our first stopping-place, Muyuka, the limit in this direction of the Bakwiri people.

Towards evening the men amused themselves in 
knocking about the football, much to the delight of the natives, who entered keenly into the game. I am the first Englishman to be seen up here.

May 22.-Owing to the sickness of the Hausa headman I was obliged to stay at Malende, two and a half hours from Muyuka.

May 23.-A six hours' trek brought us to Ediki. Between Ediki and Malende and right on to Kumba the forest is magnificent, and quite some of the finest timber I have seen in Africa. Unfortunately the country does not possess a navigable river, by which the mahogany could be floated down to the coast, so the Germans will have to depend upon the railway.

May 24.-Reached the station in three hours. The station-master was away on trek, and a young fellow, named Schultz, was in charge. It was difficult to get things arranged, as he spoke but very little of the pidgin English. The station itself is a good two miles from the native town of Kumba, and the only official residence is on a height, behind which one looks down upon a wonderful crater-lake, 112 metres in depth. There is also good fish in it, which the natives catch from canoes.

We made our camp not far from the station and overlooking the lake. At night we had a fine sight of the burning crater. We could have recorded every burst by the shooting up of the flames, and then there was the long even glow of fire which showed the course of the lava.

While at Muyuka we saw it very well.

Ali Meshi distinctly bad with high fever, $105^{\circ}$ and severe pains all over the body. I do not think it can be malaria. 
May 25.-Left for Kumba, as there is no convenience here for getting "chop" for the men, and I find I shall have to stay, as Ali Meshi is still sick; also Herr Schultz has promised to let me have twenty-three men in two days' time to take me to Ninong, near the Manenguba Range.

Quinine having no effect upon the sick man, I treated him for rheumatic fever, giving him salacin; the shot was a good one; the effect of the drug was remarkable, and by the evening both pains and fever had gone.

May 26.-Ali Meshi convalescent.

It is really amusing to observe the love the Germans have for heavy military exactitude, and it seems not only out of place in an African colony, but must be a heavy drain upon the Treasury.

After leaving Ediki a great part of the road is in deep cutting, which must have cost a prodigious amount of labour, while massive bridges of mahogany are being constructed over all the streams. If this is to save the wayfarer a little less effort, I am sure he will not be half thankful enough for it, for, having arrived at this point, another small rise or two hardly matters to him. From a traveller's point of view all these innovations are perfect eyesores. As a traveller myself, I speak. I have no objection to the ordinary native clearing of the path-that is, a certain space on each side of the track cleaned and "brushed." For all purposes it is quite good enough. I always think it is delightful, as one treks along, to be able to trace the winding of the native track, to be lost to view perhaps fifty yards ahead by some gentle bend. At every dirty little village sign-boards in "copper-plate" lettering are nailed to the nearest trees, and posts are placed in the villages themselves, thus robbing the country of much of its primitive picturesqueness. It irritates me in- 


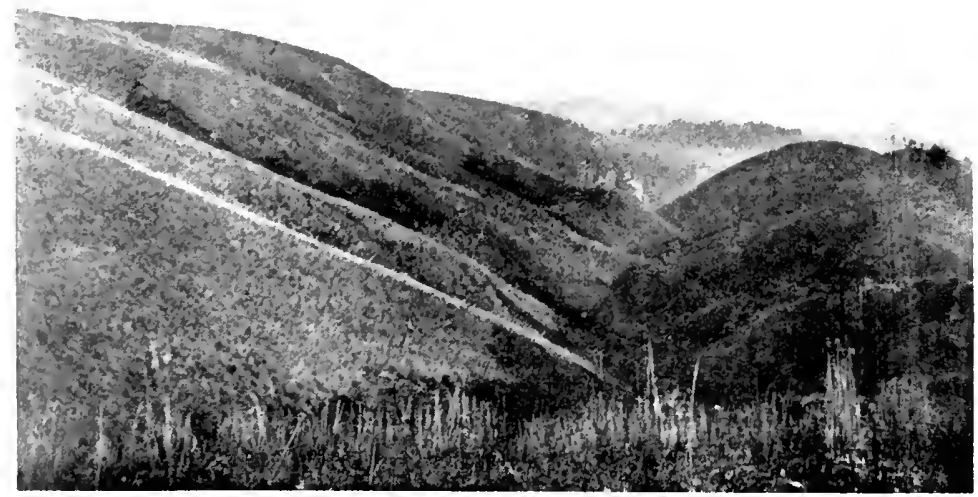

ToWARIS THE MANENGUBA RAVIF.

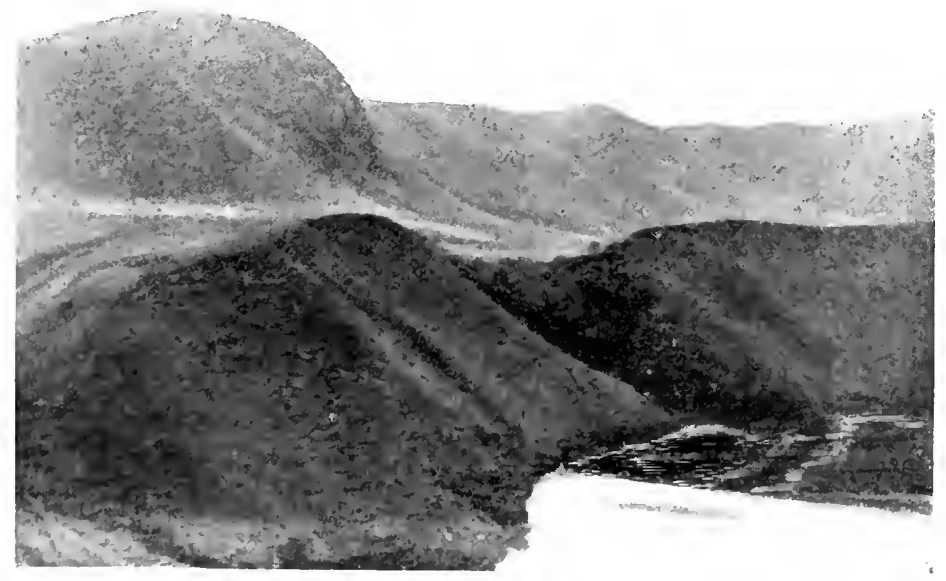

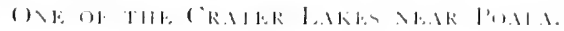



tensely. The Germans are so imbued with the military instinct that they cannot shake it off in the slightest degree; everything is done to impress; and this military tendency is even evident in their business arrangements. As an example, the House of the Woerman Line at Victoria is a perfect palace and cost over $£ 3,000$ to build, at the expense, of course, of the shareholders. Was it justifiable? Victoria is not an important place, and I think I am right when I say not more than two of the Company's boats call at Victoria in the month.

On this same principle the colony is run. When anything is done, whether it is a building, road, or sign-post, it must be of the very best, and done in the most impressive way. This is all very well, but from the view of finance in relation to the colony is it justifiable?

May 27.-The carriers having come in last night, we left for Etam, a small village of not more than ten huts and distant five hours from Kumba. With the exception of one village, about one hour from Kumba, there is no other till Etam is reached. Etam is a miserable place, and we had to send out to a neighbouring village for the men's "chop."

May 28.-Nguchi, five and a half hours, a large scattered town. The huts now are round and well built. We arrived about two o clock, just in time to get my tent up before a very heavy storm with vivid lightning came on. Below Nguchi the forest gives way to forest bush country, and from itself groups of wooded coneshaped hill are visible. Between Etam and Nguchi there are no villages, but there are the remains where several large ones have been; probably they were destroyed in a war palaver. Before reaching Nguchi one passes over a very remarkable river, about twelve 
feet wide and very deep, the water pouring down a deep cutting the whole way in stone. Near the town, and close to the road, I came across two graves. On each were piled up, to a height of about four feet, large earthenware pots, three deep, so as to form a square column, and this was encased in a framework of sticks. On the various projections made by the sticks were hung the clothes of the deceased, while a concertina and an opened umbrella were also conspicuous objects. An old tin box lay on the ground near by, while both graves had a small heap of koko which must have been put there not so very long ago. Both of these primitive monuments were in places partially hidden by the decorative leaf of the koko, which had taken root and sprung from former offerings. Of course this custom of placing the earthly goods of the dead upon their graves is pretty general with pagan tribes in Africa, but $I$ do not think $I$ have ever seen it carried to such an extent as it is with this tribe.

May 29.-After a somewhat tiring march of six hours we reached our destination, Ninong. Many villages on the road, Ngombo and Muambong being the largest. The enclosed country has now given way to undulating and hilly grass-land, while here and there in the hollows are little clusters of trees. Ninong is a very large town, and is practically at the foot of the north-western edge of the Manenguba Range. The town, like most of the towns here, is placed amongst trees and thin wood, which prevents one realising at once its extent, while it gives a picturesque appearance to the various communities of huts-in fact, I might describe it as many villages within a town.

A path leading through a patch of wood will suddenly bring one out to a row of neatly-made huts, the sloping 
ground having been cut away, so as to form a level platform. The cutting, which is at the back of the huts, is sometimes as much as eight feet in depth, while plantations of plantain and beds of koko all help to add variety of colour to the foliage. The chief food grown here is the koko; small square-shaped beds are cultivated on the slopes of the hills, giving to their sides a patchwork appearance. The people are well made and clean of limb; they are simple and do not go in for much adornment; coils of brass wire are sometimes worn below the knees. A few of the older women paint their bodies with a red dye obtained from a tree, but this is only done on occasions, such as a dance, or to celebrate the birth of a child, and the child undergoes the same treatment. At Poala, where I stayed on my way to see the crater-lakes, I saw a good example of this. A mother, all red from head to foot, was sitting outside her hut, and a baby about four weeks old was being painted. It was quite piteous to hear the squeals of the poor little thing at each daub it received. The head was already thickly coated, till no hair was visible, while a flaring red mark was drawn across the forehead.

The people here seem a hard-working lot. During the day the villages have a deserted aspect, for as soon as daylight comes the greater number of the women may be seen going into the bush, carrying baskets on their backs which are suspended with cord from their foreheads. They are either going to work on the koko plantations or to collect wood, which they have to get from a distance. Towards sundown they may be seen returning, carrying huge stacks of wood which are closely packed in upright fashion in their baskets.

May 31.-Left to visit the lakes on the hill and also to make collections. José was unable to come with me, as 
he is suffering from Guinea worm. A good two and a half hours' pull over the hill brought us to Poala, where I decided to stay. It is a large village and prettily situated in groves and clustering of trees. The people showed themselves very friendly-in fact, too much so. My hut was packed to suffocation. Everything I had came in for a minute inspection. My two sparklet bottles, which are nickle-plated, were passed from one to another, and when I showed my 12-bore, and how the ejector worked, they showed their approval by all getting up and shaking hands with me. Tobacco is the best trade goods in this country. The tobacco which one buys on the coast is done up in "heads," each head having four leaves. For one leaf one gets two eggs, or five or six cobs of corn. It is seldom one finds natives in Africa not growing tobacco. Another useful article is a diminutive burnt earthenware pipe, the cost price of which is a halfpenny. For one of these one can buy an egg.

June 1.-Left for the crater-lakes, not more than an hour's walk from the village. They are close to one another, and are called "Eddip" by the natives, or "The Two Sisters." The larger is about a kilometre in diameter, the smaller about half. The latter is almost an emerald green in colour. Unlike the crater-lake at Kumba, the sides of these are not wooded but have steep grass slopes reaching the water's edge. These two lakes lie in the south-east end of a remarkable natural arena formed by picturesque grass hills, 300 to 400 feet in height. The centre is quite flat and covered with long grass and about two miles in diameter. The height of the lakes is 6,300 feet.

Two days were quite sufficient for working the grassland, and I found that the Saxicola is common both to the Maneguba and the Kamerun Mountain. 
In the wood about the village I met again with the Nesocharis, the black and yellow weaver, the Linurgus, and Cinnyris preussi.

The connection between the Kamerun Mountain and the Manenguba is slight, but it probably comes from the well-wooded range of hills, about 4,000 feet in height, about two miles from Ninong, and running from a south-west direction to a north-east one.

June 2, 3.-Stayed at Poala.

June 4.-Left for Ninong, and found on my arrival José very sick; the Guinea worm had come out of his foot, but for the last two days he had had a high fever, $103^{\circ}$ with severe pains in his body. As quinine seemed to have no effect upon the temperature, I treated him for rheumatic fever with salacin. I had, as the Yankee would say, an instantaneous success. The next day he was convalescent. In the evening of my return $I$ went down with an attack of ague, a form of fever I have never had before. I think the mountain mists have pretty well got into my bones, and I shall not be sorry to reach lower altitudes.

June 5.-Still in bed.

June 6.-Convalescent.

Had occasion to flog a Mendie to-day. This makes the third time, and it has always been a Mendie. A tight hold is necessary with these people, who are inclined to be truculent. Yesterday they complained they had not enough "chop," and they threatened to desert. I soon brought them to their senses. I notice with grave concern a marked deterioration in the morale of our West Coast labourers. We possess in our West African colonies some of the finest labour in Africa, but 
we are rapidly spoiling them through over-pay. It is monstrous to think that the native is being paid at the same rate as our private soldier at home! A labourer gets 1 s. a day, and $3 \mathrm{~d}$. subsistence. In the Cameroons the Germans possess labour almost equal to our own, and yet the rate of pay is $6 \mathrm{~d}$. a day and $1 \frac{1}{2} \mathrm{~d}$. for "chop" allowance.

I have with me some twenty picked men from the Coast (Mendies and Hausas). They grumble at the least hardship. They cannot live on the food of the country (which after all is their own "chop") for a single day without calling out for rice. Around their camp fires at night they are always talking of money and what they will do with it when they get back to the coast. Altogether it is very deplorable.

June 12.-Left for Mbo, and after a very hilly march of two and a quarter hours arrived at a large town called Kuko. Throughout the previous night incessant rain fell.

June 14.-Arrived small town called Lumpa; good road and open grass country. Have decided to stay here to-morrow to try and get a buffalo. Towards evening I and Jose went down the road to the north, and though we found plenty of spoor, we failed to find the animals.

June 15.-Made an early start, and though our guide took us to some very likely spots we had no luck. The country is long grass, with here and there patches of forest growth-a true buffalo locality.

June 16.-Left for Nshenshu, four hours. Here is a rest-house situated on high ground from which one has a splendid view over the country to the south; a vast natural arena enclosed by picturesque hills, some grass- 
covered, others clad with wood, and with an altitude of about 4,000 feet. The south is shut in by the Manenguba Range, and near it is the Kupé Mountain, a mixture of forest and grass-land.

June 17.-José left early to try and get a buffalo.

While sitting on my bed I was greeted with a "Good morning," and the next moment an Englishman, or rather a Scotchman, entered my room. His name is Alexander McAllister and he is an elephant-hunter who has killed his five hundred elephants. He has seen most of the globe, and can tell many interesting sporting adventures. He has been all through the Logo and Lugworet country in the Congo. This was the part I was anxious to have gone through. He was near Gondokoro when I arrived on the Nile at the end of 1906.

José returned having seen no buffalo. These animals seem extraordinarily difficult to find, though one sees plenty of spoor. I think that this should be a new species, a link between the Congo and the Northern forms.

It is a small animal; the cows are red and the old bulls are black. It seems of very local distribution, only being found in the valley and about Bare to the south. There are also a few elephants here. It is curious, but buffalo always follow the track of elephant. McAllister bitterly complains of ever having come here. It is a wretched country for game and the last place for the sportsman. He killed a kob somewhere near Jang, and describes it as different from the ordinary species. It has some white spots on its back. He is also of the opinion that the leopard here is distinct-a much smaller species and very dark in colour.

Last night two natives were killed by an elephant not far from where McAllister is living and about three hours 
from here. This aggressive trait in the character of the elephant is quite new to me. His method of killing his victim is quite admirable; the man is taken up in his trunk and dashed to the ground, and then the elephant stamps on him.

June 18.-Determined to make one more effort to get a buffalo, so left before daybreak and joined McAllister at the village where he is stopping, about three hours from here. We all started off and eventually reached some marshy ground through which a river runs. Flocks of whistling teal and spur-winged geese were there. Numerous spoor also showed it to be a favourite haunt for buffalo, but my luck was again out and there was no other sign of them.

The soil here is very rich and produces some very fine corn; two crops are taken in the year. The food is expensive-2d. for a bunch of plantains. There is an enormous amount of palm-oil and kernels here. It will be a rich source of revenue to the Germans when the railway is completed.

There is a good supply of marketable labour here, especially of women, who are excellent workers. The men do nothing except sit in their huts all day, unless hauled out of them by the white man for work. As soon as it is daylight the women may be seen leaving the villages for the farms and returning at dusk with heavy loads of wood or "chop" * on their backs.

June 19.-Left for Mbo; a hilly road; the valleys and ravines were for the first part of the journey thickly wooded and full of palm-trees. Arrived at the post after a three hours' trek. On the way we met a German trader coming down with over ninety head of very fine cows

* Term used everywhere in West Africa for food.-ED. 
which he got from the Marua country. This must be a paying business. On the coast a cow fetches $£ 7$; the average up-country price is $£ 210$ s.

The altitude of Mbo is 2,500 metres; it is full of mist and very cold. It is in charge of a sergeant, a very superior and intelligent man.

June 20.-For the first two hours after leaving Mbo the scenery is very peculiar. The hills and valleys are clothed with trees, every branch of which is thickly coated with moss; one feels they must be almost suffocated. Even the path is overgrown with moss, save the track itself, which is worn by passing feet.

At length one emerges into a wonderful expanse of steep, down-like hills, all grass-land of an emerald green that sink into deep folds and valleys. Here one often sees the rise of rivers, columns of water, like silver streaks, pouring out of the very bowels of the hills. The road now becomes very winding, being cut out of the sides of the hills, and following their contours. On one side one looks up to steep grass-covered slopes, on the other down into deep valleys, the lowest level of which is outlined by thick belts of feathery palm-trees.

A march of three and a half hours brought us to the first rest-house.

Small but very good potatoes are grown at places for the benefit of white men. They are a great boon after the somewhat sickly sweet potatoes. The labourers' "chop" consists of corn, plantain, and sweet potato, and $1 \frac{1}{2} \mathrm{~d}$. is the "chop" rate per man per day.

June 21.-Left for Jang, and arrived there in four hours. This is a large post, with something like six white men and forty soldiers. There is also a large Hausa settlement. The people here are the Bamilleki, 
a large tribe, the name meaning "people of the grassland." This describes the country well ; there is nothing but grass now. This tribe are well built and strong and very black; the forehead and temples are shaved, but at the back of the head a matted mass of close-twisted ringlets hangs down. Their ju-ju is peculiar. At the entrance of their towns are built small square huts, generally encasing a tree, and in them are put a number of large stones. Jang is only a small district, but it has a large population-some fifty thousand. The interior now is becoming very thickly populated and cultivated. The sides of the grass-hills are squared and chequered with plots of the koko and sweet potato. Since the Germans have put a tax on every working man (6s. for the year near the coast and $4 \mathrm{~s}$. in the interior) it must bring in a good source of revenue. Besides this tax, each chief in rotation has to supply to the post a certain number of labourers for a month. These after completing their work are not called upon to pay the tax. Every chief gets 10 per cent. of the money collected from his people.

I have decided not to go to Yola now; it will take too much time; instead I shall make for Ibi by Bamenda, distant from Jang four days. Bamenda to Kentu four days, Kentu to Takum two days, Takum by Wukari to Ibi three days.

June 22.-Left for Bamenda; arrived first rest-house in three and a half hours. The rainy season is now on the point of commencing. There was very heavy rain yesterday evening.

June 23.-Second rest-house, five hours. The road in places much overgrown and quite deserted. The only three men I saw, on catching sight of me, rushed like 
madmen into the long grass. Spears are now carried by the natives.

June 24.-Third rest-house, four hours ten minutes.

The country now is a wonderful display of rolling grass-covered hills whose re-entrant angles are thickly wooded. It is also a land of waterfalls ; I passed no less than three to-day-great volumes of water pouring out of the hill-sides down into the deep ravines below.

June 25.--Reached Bamenda in three hours. A large station, in the throes of being repaired; consequently the acting Commandant, Herr Adametza, was unable to give me shelter, but he came with me to a Herr Menzel, who has a store and outhouses about ten minutes from the station. The latter at once gave me a large building, which he had just built, for myself and my men.

How small Africa is! The first man to come up and salute me was the corporal of the escort I had from Maifoni to Lake Chad, Garuba Kukawa, a Kanuri. He was in the service of the store man as horse-boy at a monthly wage of $8 \mathrm{~s}$, rather a come-down after his $30 \mathrm{~s}$. a month! After leaving the force he went from Yola into the Cameroons with 30s. in his pocket in the hope of picking up a means of livelihood. There is a large settlement of Hausa and Kanuri at Bamenda, and at other places as well.

I think Garuba Kukawa will be very useful to me as he has already been to Wadai; he seems confident of being able to take me there by a road which will avoid both the German and French posts. This road crosses the Shari to the north of Gulfei. When we reach Ibi he will go with José to Kano to buy camels.

Very heavy rain this afternoon about three o'clock. This occurs every day now. Bamenda is surrounded by 
high grass-covered hills, especially on the north-west, and running to a height of 4,500 feet.

June 26.--Stayed Bamenda. Gave my little cat to Menzel, who has several and seems fond of them. I should sooner or later have had to give it away, and with him I think it has a good home.

June 27.-Left Bamenda and reached Bambili, a scattered town in a patch of forest. The people here do not trouble themselves much about clothing, the young girls and women go naked. A few of the older ones wear a diminutive curtain of native-made cords, the end of each being hung with a cowrie shell. Cowrie shells are liked here, as well as beads blue and white and of a large size. Towards evening there was a picturesque native bush-market in a clearing in the forest just off the road and not far from the king's house. It was composed entirely of men and boys, who must have numbered when the market was in full swing something like two hundred. The bodies of nearly all were stained a dark cutch * colour, and so were their clothes, and the effect in the waning light appeared from a distance like a confused reddish blurr, against the dark foliage of the background. The men came from all directions, bringing with them their produce in grass-woven bags. There were rows of large gourds full of palm-oil, and these presented an imposing array, with their owners squatting behind them. There was much bush meat too, small red antelopes and the headless body of a bush buck. With some of it putrefaction had set in, making that part of the market unbearable. Small fowls were also there for

* The red-brown dye from an Australian bark that is used for tanning the sails of fishing-boats.-ED. 
sale. Several men pandered to the taste for the adornment of the body, and on pieces of banana leaf there were for this purpose neat little heaps of red dye, mixed with mud. Many of the men had slung on one arm a rough-sewn bag made of the skin of bushcats and containing their small needs for the road, such as cowrie shells. I bought no less than four of these bags, each skin belonging to a different species of bush-cat. These purchases were greeted with roars of laughter, not born of ridicule, but rather of surprise that the white man should bother his head about such small matters. Outside the market ring the gambling element had congregated. Groups of young men and boys were playing a form of dice with cowrie shells, a sight that reminded me irresistibly of a race meeting at home. Suddenly the babble of the market stopped. I thought something serious had happened for blackmen to cease so suddenly their talk, but it was only because the "king of the market" was haranguing them, and the gist of his speech was that it was bad to bring bush meat into the markets with the heads cut off since the big Englishman said it spoilt the skin. Then the talk resumed stronger than ever till darkness fell, when the market began to melt away, both buyers and sellers dispersing in all directions.

The houses here are very large, square-shaped and built of red clay and bamboo, and from eighteen to twenty feet in height, with thick thatched roofs. Each is practically a house within a house, for between the inner dwelling and the outer wall there is a narrow passage all round. They are almost pitch dark.

June 28.-Arrived Babenki, three hours. On the way we met the Commandant of Bamenda returning from a bush tour with ragged soldiers and a great 
train of followers, while prisoners, quite decrepit old men looking more like scarecrows than anything else, were being shoved along by the soldiers. He did not impress me. When I told him I was going to Ibi by Kentu he struck in by saying I could not take into English country German carriers without paying $£ 5$ a head for them. He thought it a poser, no doubt, but my reply was that I had my own men! Here is another example of the wisdom of having one's own followers on an expedition of this kind.

June 29.-Arrived rest-house; very hilly road, six hours.

June 30.-Reached Babukon after a most trying march of six hours over very hilly country. This road is hardly fit for transport. The whole country is a mass of steep, rolling downs of green grass which is most delicious and pleasing to the eye. It might well be called the Emerald Land.

July 1.-Made an early start with the idea of reaching Bafum-bum. For the first two hours the hills made travelling difficult. Then we descended into a broad valley with the road practically level. Two and a half hours brought me to the small village of Babuchang. On passing through it the chief would insist upon my stopping and refreshing myself with "Mimbi," * then he brought out some corn cobs. I took one for the road, but he begged that I should put another into my pocket.

Within about two hours of Bafum-bum the hills break up into small ranges of rolling kopjes. Altogether I took seven hours' actual walking to reach the town, too long a trek in the rainy season. It was past four * Palm wine.-Ed. 
o'clock before all the carriers came in, and they had to march through heavy rain. The king, who rules a big country, "dashed" me well, giving me ample "fu-fu"* for the men, as well as a sheep.

July 2.--Stayed Bafum-bum.

Another attempted mutiny on the part of the Mendies. It appears that the Mendie headman went to the Hausa headman and said his men were ready to refuse to go on if he would get his to do the same. Luckily the latter refused and reported the matter.

July 3.-Reached Dumba in five and a half hours; the road in places much overgrown; with the dew on the grass it is like being in a cold bath the whole time. About two days to the north of this place there are a great many buffalo.

July 4.- Made a bush camp four and a half hours from Dumba. The hills are gradually disappearing, but they are as green as ever. Narrow belts of trees wind serpent-like down their sides, following the course of their hollows.

July 5.-Arrived Kentu in four hours. This is a small German station made about six months ago. It lies low, the land descending very abruptly to it. On the hill above it the path was strewn with lots of mica. Before reaching the station one passes through a Hausa settlement. These people collect rubber. The clerk of a small trading store here tells me that he takes in the wet season about two thousand kilo of rubber, but this amount falls down to two hundred and fifty in the dry time. Unfortunately I found the white man away on tour, so could do nothing in regard to getting carriers, and I had to leave nine loads with

* A mess of cassava and yams.-ED. 
the clerk, and I shall have to send back for them from Giddan Sama.

July 6.-Left for Giddan Sama, a most trying march of eight hours, but failed to reach the town, owing to my guide, Garuba, taking the wrong path, which brought me to a small town called Gargai, and out of the Giddan Sama road. Thoroughly tired out, we made shift for the night in some wretched tumbledown hovels.

With the exception of distant groups of hills, the country is quite level, and covered with the familiar bush forest, which is thick in certain places.

July 7.-A march of two hours brought us to Giddan Sama, where we were warmly welcomed by the Hausa chief and his men, and with that polite deference which at once raises the Hausa above many of his fellow natives. This is a small town, and all Hausa, and it is not far off the Donga River, which below the town is a good 150 yards in width and runs with a swift current. There are some rapids, but I think in the height of the rains they would be covered. The day has been very close and muggy, which makes me feel limp after the very bracing climate we have just left behind.

In the evening there was a glorious roseate sunset. Such sunsets by no means mark the close of every day in Africa, neither do they bear out the old saying, "red at night is the shepherd's delight," for during the night and the greater part of the next morning there was much rain. The sky effects are not easy to describe. When the sun dipped below the horizon, a broad, rosy band of light suffused the sky. Above and lying in sharp contrast were billowing banks of mauve- 
coloured clouds which stretched to right and left as far as the sun's glow. Then higher up the sky was of the faintest blue. A sunset like this is enhanced by the brief twilight, which tends to deepen the colours with such dramatic suddenness before one's gaze that they combine both a wrathful and peaceful effect.

July 8.- Stayed Giddan Sama, and sent some of the men back to Kentu. José is down with fever.

July 9.-Went out early this morning to try and get some meat, but it is a gameless country; only a few kob are to be found. Tramped for several hours and saw nothing, although in a country one would think teemed with game, for there were tracts of bush forest with excellent short and tender grass; but all was silent as the grave. Here and there trees with all their branches blackened by former bush fires would stand less thick, so that they formed open glades.

July 10.-Prepared for a start, but at the last moment the carriers whom the king promised to give me were not forthcoming. He had already sent a messenger to Ido, a bush village on a hill about one hour's journey from Sama. I always have a distrust of people who make their homes upon the sides of almost inaccessible hills; they either fear or wish to avoid the white man's burden.

The king sent yet another messenger, and José followed with several of my men. His arrival was a signal for a general exodus, the men refusing to come in, and hiding away in the numerous caves on the hill-side. After much hunting and climbing about the rocks Jose eventually discovered the chief of the village in a cave and captured him; but not before he attempted 
to spear one of my men, so several shots were necessary. Jose brought the chief in, with the eight men required. I "palavered" him well, and in answer to my question why he refused to give me the men, he replied that he had no power over his men. All nonsense, of course, so my retort was that a chief who was strong enough to spear one of my men was strong enough to rule his people.

July 11.-Before leaving for Takum the king of Giddan Sama complained to me of his treatment by the Germans, who make this one of their stopping-places on their tours. Only a few days before I came the white man from Kentu had stayed for three days with a following of something like fifty men. He forced the chief to feed his men and then went away without paying him, and also taking with him three of the men of Sama, who never returned. This had frequently happened, with the result that the village has a most deserted aspect; either the people have been taken on previous occasions or have run away, fearing to be captured. Women have also been taken. The poor king (really a charming old man with a personality) now sits under his sun-shelter in the market square, a lonely and disconsolate figure surrounded by three or four headmen, whom the Germans dare not lay their hands upon, while on every hand the huts are deserted. I asked him whether the Commandant of the Boundary Commission, when he was here some months ago, had told him that his town was English. It was quite pitiful to see him throw up his hands towards German country, and then towards ours, saying, that the white man in passing said, "Lakka German" (over there is German), "Lakka English," but he was never told on which side his town lay. He was quite relieved 
when I settled his doubt and told him I should put his complaints before the Resident at Ibi.

Made an early start and reached a Hausa bush camp, four hours on the road. To-morrow we shall be at Takum.

July 12.-After a tiring march of six hours we reached Takum. This is where José collected for a week in 1904, while our expedition was at Ibi. The king, who is a Jukun, is big in every sense of the word, of portly presence. He came to greet me with a large retinue. It was not long before a legion of women arrived to clean the open space in front of my house, and wood and water were brought for the cook. Then a number of calabashes of "fu-fu" arrived for the men, quite a three days' subsistence. All this is in striking contrast to the way one is treated in German country, where the system is one of coercion. Though at times we are too lenient with the natives, yet, taking them all together, our methods give, in the long run, distinctly the more pleasing results. I feel convinced that by our kinder methods we have, so to speak, begun to glide into the native life; in fact, they look upon us as part of themselves.

Soon after the king left the Mallam, with his following, including the "king of the market," came to pay their respects. The Mallam, an old man, in flowing Hausa robe and white turban, was an impressive figure, and I felt I was in the presence of a holy man. He greeted me with that beautiful Hausa word, Marraba, which means "Welcome, stranger from a far land." This is the second time I have heard the word used; the first time was by the Emir of Bautchi, when I was there in 1904. Hausa is a beautiful language, particularly because of its simplicity of construction. 
Another pretty word is madalla, which is used as an expression of thanks when any welcome relief has been given. For example, when at the end of a long day's march the welcome sight of the village meets the gaze of the tired traveller, the word madalla might readily escape his lips.

Takum is a large town that was once walled; but now the broken-down walls are replaced by a peaceful zana matting round the groups of houses, an eloquent sign of the white man's rule.

Towards evening I went down to the market, which is a large one. In one spot were a knot of market loiterers looking on at a man driving his trade, cutting patterns on the arm of a woman. Behind him was a man vigorously beating a drum, and near by another who cried out in hoarse tones, exhorting the woman to be brave. I caused great amusement by asking the man to make a pattern on my arm. Fearing some ill consequence, he flatly refused at first, but the offer of a good "dash" made him take on the task, so I sat down and bared my arm, amid much merriment and excitement. The drum was beaten louder than ever, but the man who exhorted remained silent, saying, "The white man is always brave." The process lasted some ten minutes, and the pattern when finished was in the form of a $Z$, made by numerous small upright incisions. Then a liquid mixture of pounded charcoal and butter was rubbed into the cuts, and this had the effect of stopping the bleeding at once.

July 13.-With ten carriers given to me at Takum, we reached a village called Giddan Adamu in two and a half hours. On the march it is my wont to get on in front, and I generally arrive at my destination about one and a half hours before the carriers. It was so 
to-day, and after a fatiguing march I had just reached Chinchingi, when a native arrived in hot haste from José, saying that at Giddan Adamu several of the Takum men had run away; so I had to trudge all the way back, altogether a continuous trek of eight and a half hours. This speaks well for my strength.

July 14.-Arrived at Balama, the first Munshi village, in one and a half hours. I am quite lost in admiration of the Munshi men; they are wonderfully well developed, with clear skins which are died a very dark claret red. The hair of the head is shaved, with the exception of a plaited tuft on the side of the head above the ear. They all carry spears, or bows and arrows, which are poisoned. Their houses are circular and very large. The king's house, in which I stopped, was at least thirty feet in diameter. On the walls were hung several masks of horses, and near to them two cow's heads fantastically done up with grass rope. It is a custom among the Munshi for a chief, when he marries, to give the woman a cow. This is killed and distributed amongst the guests at the marriage feast. In this case the two heads showed the marriage of two women.

The dead are buried outside the villages. A slight mound is raised, then thorn branches are placed on top to keep off wild animals, while on the branches themselves the dead man's clothes and hat are spread. The tribal marks are a series of circular raised bumps on each temple in the form of an arc $a$. Sometimes are on the forehead and chin.

July 15.-After a very tiring march of eight hours through a burning sun, and with no water for the last three hours of the journey, we tailed towards late evening into Wukari. I entered the place with feelings 
of sadness, for I realised that there would be many things during the next month to remind me of the time when Pickles was with me, in 1904. It was here that he came to stay for a few cays to recruit after his attack of fever, and I am now living in the same hut he lived in.

Before getting into the town I passed the Crocodile Pool,* which is described and pictured in my book. Here San Thomé had a narrow escape. After a hot march he jumped into the shallow water and laid down within two feet of a huge crocodile, which peered with gaping jaws out of a cavernous fissure. At the time there were many women and children bathing and washing close to the animal. They shouted frantically to me to drive the dog out of the water, but San Thomé, oblivious of the danger, refused at first to budge, and I had to use my stick.

Wukari is a large town of Jukun and Hausa; it was once walled. Towards sundown the market, which is a big one, presented a very lively appearance, and one could not help feeling a thrill of pleasure at the sight of so much prosperity, which we have drawn into our dominions and nursed so well.

July 16.- Stayed to finish labelling the last collection of birds from Manenguba. During the work a number of Munshi, who came to the market here from neighbouring villages, gathered round the door-

* A little pool, only twenty feet long, but very deep. The natives say it springs from an underground river. It is the home of a number of crocodiles, which have dwelt therein as long as the memory of man, and are believed to have come up through the sources of the water. They are held sacred by the natives, who come down and wash all among them on perfectly friendly terms. -ED. 
way, all lost in admiration of the birds, especially the bright-feathered ones. The Munshi are very keen hunters, and are extremely fond of feathers.

Have been very unfortunate in not being able to find the crocodiles out in the pool, though I have been down three times to-day. Pickles was extremely lucky to get the interesting photograph that he did.

July 17--Left for Ibi. Meant to have stayed at Rafin Solder, distant four hours, but found the people had practically deserted the place, and consequently no "chop" was to be had.

Arrived Ibi in another three and half hours. I set out for the place where Pickles and I stayed in 1904, but found the spot very much altered-in fact, all the old huts had been pulled down by the Government, and a well-built mud hut with cook-house erected as a European rest-house in their place. This I was sorry for, as I should like to have seen the place of my old recollections. It was here that Pickles was laid up with fever, and here that I helped him with his transport for his journey into the Wase country. In fact, when I said goodbye to him at the river bank it was the last time that I was destined to see him in health.

Ibi, as a station, has changed very much for the better. The old tumble-down residency is now superseded by a well-built, airy bungalow, but the magnificent brick wall which surrounded the old building has been kept and is being repaired. Three other bungalows have been built on the same rise of ground, but further to the west. These form the quarters of the provincial resident (O. V. Elphinstone), the doctor (Lobb), and the police officer (Ellis). Altogether there are four European officials here, including Holme, who 
is the local Assistant Resident. In many ways the station has been vastly improved, and I am certain it has gained from the health point of view. For one thing, much clearing of the ground has been done, and only the best trees have been left standing.

July 18.-The telegraph wire is down and consequently I can do nothing towards getting money, but $\mathrm{Mr}$. Holst, the manager of the Niger Company, has generously come forward and said he would take my cheques on a home bank. But unfortunately money is scarce in Ibi just now, and he found he could only let me have about $£ 225$, and this was scraped up with a great deal of effort. Anyway, with the money I had left, $£ 20$, it was enough to pay off the men (£163 15s.), and allow of José's going to Kano to buy camels (£70). I am heartily glad to get rid of the men. The Mendies have been most truculent. Previous to their being paid off, they again refused to obey an order, and I had to ask Ellis to deal with two of the offenders. The sight of the police brought the remainder to their senses. I consider that the Mendie is the last person to employ on an expedition. $\mathrm{He}$ is quite intractable. Of course, as soon as they got their pay the usual gambling with the cowrie shell commenced, and more than one lost every penny of his money. The Government really should do something to stop this. The next thing that always follows is that the winners lend their gains to the losers at exorbitant rates.

It is wonderful what deference is paid to the white man by natives of all classes at Ibi. It becomes quite irksome to go through the market, and I always think that one should, if possible, acknowledge the salutations. On one's approach groups of men sitting by the side or at the corners of the street will rise up and stand 
respectfully till one has passed. Passers-by, many turbanned and clothed in costly togas, will pause to take their sandals off, or at other times to bend to the ground.

Within the last year two new coins have been introduced, a nickel penny, and a smaller one of one-tenth the value. The latter has taken the place of the cowrie shell. Both coins seem to be popular.

In the market now cigarettes are sold. This is quite a new thing. The boxes are sold at 1s. 6 d. each, and the chief buyers are carriers and small boys. They are brought from Lokoja at 1s. 3d. a box, and at Yola the price is $2 \mathrm{~s}$.

The caravan tax has been withdrawn. This while it was in force used to bring into the Protectorate's exchequer $£ 42,000$ a year. Within the last year an income tax has been imposed. The Resident of the Provinces assesses what each town is able to pay, and the chief is then told to collect it. He does so, calling upon each man to pay according to his means. This tax is readily understood by the natives since it is nothing more than an improved administration of one of their own laws, and of course it is far more fairly done now than in the old days, when a chief levied what he liked upon a town, which always suffered severely if it was in his bad books.

An amusing story, if it did not end so tragically, has just been told me of how other people's money is squandered away in exploiting concerns in West Africa.

A certain adventurer and elephant hunter whom I have made mention of in my former travels plays a prominent part in the African tragi-comedy. $\mathrm{He}$, in course of time, after having burnt several villages in the Cameroons, returns to Ibi penniless, with no dis- 
coveries of mines up his sleeve. He goes to the manager of a certain company and gives him a glowing account of the rubber in the country he has prospected in, and offers to collect it for him on the loan of $£ 60$. But the amount he guarantees to collect in a month so far exceeds any known in the wide experience of the manager that the latter is wary and refuses. Our friend, reduced by now to dire straits, next brings to the manager his elephant-gun and asks for a loan upon it of $£ 5$. This he obtains. He then disappears into the native town, where apparently he sits down for some time.

The scene now shifts to another part of the Protectorate. Previous to the arrival of our friend at Ibi, a man named A buys from the Niger Company at Lokoja a sample of rubber and goes home with it, and on the strength of it raises a substantial sum of money from certain wealthy City men to run a rubber concern in Northern Nigeria. Two kindred spirits, B and $\mathrm{C}$, go out with him, and they eventually find themselves at Ibi. By this time our friend is pretty well on his beam ends again, and he bails the arrival of these men with satisfaction and loses no time in fastening on to them. His knowledge of the country and his tales of rubber soon procure for him a position as guide, at the nice little sum of $£ 30$ a month, on the promise that he will show his employers where the rubber is to be found. He now advises that one of the party should go down to the coast and bring up a lot of trade goods, while in the meantime he should go into the Adamawa country to buy donkeys for the transport. This is eventually carried out, and our friend comes back with something like sixty donkeys. Then a start is made into the Land of Promise, but 
the donkeys prove a dismal failure, many dying from the tsetse-fly, while those that do not are apparently seized with a warning of their threatening fate and stampede into the bush with all their precious loads, never to be found again. More goods have now to be obtained at Ibi and carriers requisitioned, and so the expenditure of their funds rapidly increases. Eventually a fresh start is made, and the party settle down in a rubber-producing district. In the meantime one of the party gets blackwater and has to return home. Next, our friend, having amassed some six months' pay, finds it would be wise to return home owing to his bad health. Accordingly he leaves his two companions, but promises to come out again. Exit.

Letters now begin to come from the anxious shareholders at home wanting to know when to expect the first consignment of rubber. By this time $B$ and $\mathrm{C}$ have collected about 50 kilo, and the former suggests that he should take it to the station and ship it home, pointing out that it would also be an opportunity for replenishing their stores, which are getting low. On arrival at the station $B$ sells the rubber and decamps to Europe. Exit B. In the meantime C, who waits in vain for the return of $B$, goes raving mad, wanders into the bush and gets eaten by cannibals.*

July 23.-José left this morning for Kano, to buy five camels. It will take him about a month to reach there, so I shall expect him at Maifoni, where we are to meet in about six weeks' time.

Every one was very much surprised to see me turn up

* It may interest the reader, but hardly satisfy him, to learn that the chief actor in this drama, the elephant hunter, was subsequently sentenced to eighteen months' hard labour for trundling a nigger in a spiked barre à la Regulus !-ED. 
at Ibi. It is quite a comfort to feel that one's movements are not known ahead. In the old days, when white men in Africa were few and far between, one's approach was heralded at least three days in front of one; but now the natives have become so familiar with the sight of white men, that they no longer carry from one town to another the news that a white man is approaching. So if the opening up of Africa has done nothing else for the explorer it has at least veiled his movements with secrecy.

July 29.-Had the carriers up to find out if they had made up their minds where they wanted to be sent to. The Mendies all chose to go to Lokoja and the Hausas, with the exception of three who went with José to Kano, wished to return to Sekondi. I have given passage money to all, and have hired a canoe to take them down to Lokoja.

July 30.-More trouble with the Mendies. It took me three hours to get them off. I had literally to drive them into the canoe. They are the worst type of native I have ever come across.

July 31.-The Niger Company's steamer came in last night, but unfortunately it had been chartered by a French Company, and two Frenchmen are on board. At my suggestion Mr. Holst approached them about a passage for me. They were very gracious and consented at once.

Left about one o'clock.

It is rather remarkable, but I find the two Frenchmen are agents to the Nana Company at Krebidje. This was the Company I bought a good many stores from when I passed through that place. Their names are Giajola and Dumas. They seem to have an unlimited supply of outfit and all of the very best. They are very hospitable, 
and will insist on my having meals with them. It is a long time since I have enjoyed such well-cooked meals. The Nana Company is a rich one. It appears they have bought up all the Government boats on the Shari, and have undertaken to supply the stations, and will probably do so by way of the Benue and Tubouri.

August 1.-A most glorious sunset last evening, that almost dazzled the eyes, so quickly did the hues deepen and change. When the sun dipped behind the sharp-cut edge of a range of rugged hills, all bathed in purple, the sky flushed a deep rose red, melting towards the zenith into a tender blue that changed to palest green before the gaze, while from the brilliant dome hung many strata of deep violet clouds. Beyond this floating radiance and over the northern sky the beams of a full moon shot up brilliant and defined as those of a searchlight.

August 4.-About eleven o'clock we arrived at Yola. The manager of the Niger Company gave me a small house to stay in, as the barracks are two and a half miles away from the Company. I drew from him $£ 100$. Of all the stations I have visited in this country I do not think I have seen a less happily chosen site if utility is the thing considered. Placed two and a half miles from the only anchorage, it has not even the advantage of being in touch with Yola. It is situated at the end of a rise of ground that falls abruptly on the north-east and south to the river level, where in the rainy season a vast marsh separates it from the town of Yola, whose position is only indicated by a thick belt of trees which hides the houses from view. Close to the Niger Company is the village of Gimeta, dirty and ill laid out. It is a Hausa and Fulani settlement under a Hausa chief. To my mind the right position for the barracks would have been on a slight 
prominence, rich in shady baobab-trees, that lies to the left of the road towards the present barracks, and about a quarter of an hour's walk from Gimeta. All the officials have been extremely kind to me. They are Barclay (Resident), Dwyer (next in command), Stone (commanding the soldiers), Dix (police), Dalziel (doctor), Boyle (Assistant Resident).

If anything can be said for the position of the station it is the view towards the north-east, and this is magnificent. Towards Garua there lies a vast plain of bush-covered country, stretching as far as the eye can reach, while towards the south, distant about ten miles and running from north-west to north-east, are the picturesque Verre hills. This range is inhabited by the Verre tribe, pagans who wear leaves, and their huts are perched upon the almost inaccessible portions of the hills; but since our administration of the Province a healthy sign of our influence is that many of these people are leaving their strongholds amorg the rocks and are settling on the plains below, which they realise is to their advantage, since they can grow double the amount of crops on the rich soil of the plains as compared with what they have grown on the stony ground of the hills. Yet there are many who still stick to the hills at points where they can dominate the trade routes and carry on a system of murder and robbery. A fat Hausa trader coming along with his following will be swooped upon, his throat cut, and his goods and belongings taken up into the hills, and then perhaps, some months later, the travelling official comes along and is received by these charming people with open arms, so to speak, but when he accuses them of the murder they shake their heads, hold up their hands in horror and say they know nothing about it.

The lack of made roads in the Province must be con- 
ducive to this lawlessness. We go just to the other extreme of what the Germans do. Were they to be cleared the roads would become more frequented, and chances of murder and robbery would thereby be lessened.

The Verre pagans are strongly built and thickset, and have negroid features. Iron bars and hoes are currencies among them. The young men of the tribe cannot marry until they are possessed of thirty hoes, and these are given as a present to the uncle of the bride. Just before the birth of the first child the wife goes to her mother's house and does not return to her husband's compound till two months after the child is born, while two years nust elapse before she can again share his bed. All children belong to the mother and inherit from her and from her family, while the possessions of the father pass to the children of his sister.

The Verre method of burial is also interesting. On the death of a man the first skin is rubbed off, the idea being that he should not be buried with a dirty skin. This is usually done three days after death. Then a pit is dug, in which the body is put standing upright, or, rather, hanging by the head, which is placed in a vice of stones, and then an earthenware pot covers the whole. After a time the body becomes detached from the head, and falls to the bottom of the pit. The skull is then taken to the compound of the head man or woman of the deceased man's family and is kept in the hut. This is only done in the case of important people, and then, too, the grave is dug inside the hut of the deceased, while in ordinary cases it is dug just outside the compound. The Batta pagans also bury upright. The Fulani bury lying on one side.

The conviction and exiling of the late Emir of Yola to Lokoja in April last is still the topic of conversation. 
I have, through various sources, chiefly native ones, obtained some interesting facts which led to his conviction.

This Emir was always kicking against the Government; in fact, he was an impossible person to deal with. I think great credit is due both to Barclay and Boyle for the prompt way in which they managed the case, for it was quite possible that his arrest would have led to disturbance and bloodshed. Of course, a nice point might be raised as to whether Barclay had the power to bring to trial and depose a reigning sovereign in a Protectorate, but I consider an exception is justifiable in the present instance.

When Yola was effectively occupied in 1901 the then Emir, Zubeiru, fled into German country but was driven back by the Germans across the border, where, according to common report, he was killed by the Lala pagans. But for his hostility to the white man he might have retained the Emirship, but in reply to our offer of friendly protection his answer was, "I will not bend to the white man." Since the days of his flight and reported death a belief bas been gaining ground that he is not dead but living with the King of Mandara, and, further, that he has had a son born to him. Whether this be true or not is of little moment, for he is an exile, and Yola would offer him no haven. Zubeiru was succeeded by his brother, Bobo Amadu, who appears to have devoted his reign of some eight years to a long series of secret crimes and extortions, which the authorities found extremely difficult to bring home to him till the present year (1909), when he was tried and convicted on the charge of inciting to murder and extortion, and then deposed without bloodshed by the smart action of the British Resident. In order to realise the nature and extent of 
the Emir's extortions it will be necessary to give a few instances.

He possessed an inordinate love for amassing money, the accomplishing of which was rendered easy by his power and position, while his commanding presence helped him in no small degree to further this end. Darkskinned, tall, and stoutly built, and with white beard flowing from the chin, we can picture him surrounded by some hundreds of richly gowned horseman, riding into the country to visit his towns, where he would demand without payment double the amount of food required for his men, and then order the remainder to be sent with him. The chief of a town named Zuma, warned of his coming by a messenger, had the best house and compound made ready for his royal master. The bed upon which he was to recline and the floor as well were spread with costly gowns. In the centre of the bed shone a heap of silver, while at the head and foot knelt two young virgins ready to receive him. Such presents as these could only have been the outcome of intimidation, for, often when the Emir required money, he would summon the brother of a chief and would tell him that on payment of a certain sum he would drive his brother away and make him chief in his place. Under such circumstances it is little to be wondered at if a chief did all he could to propitiate the Emir when the latter visited his town.

At the foot of the Verre hills there lives a lowan* who has ever been faithful to the white man. He is old now and blind, but in his time has been a great fighter, and he will tell you how in his fights he either killed a foe or took a slave. Even now, whenever he hears of a

* "Lowan" is the title of a chief ruling over several towns, but sub. ject to the Shehu; he holds much the same position as a baron in mediæval times.-ED. 
white man approaching his town, blind as he is he will ride out to meet him; in fact, he is never without his horse, for it is to him as the blind man's stick. But the peaceful days of his old age were once rudely disturbed, for the Emir sent for his brother and said to him, "If you give me four cows, I will make you lowan in your brother's place." As soon as the cattle were given, the Emir acquainted the old lowan of his danger, and demanded of him also four cows, and his horse as well, if he still wished to retain his position. The old lowan burst into tears and came to his royal master and said, " Have pity, I am poor and blind. Do not take away my only horse, my dearest possession and the only guide through my darkness!"

Perhaps most subtle of all his iniquities was the manner in which the Emir invited the pagans to put out of the way those whom he disliked. It was at a town named Vanga Malabu, in a pagan dependency, that a particularly brutal murder was instigated by him, the discovery of which led to his trial and downfall. This town is in the country of the Batta pagans, the head town of which is Malabu, distant from Yola about a three-days' march to the north-east and lying close to the German frontier. For years past Malabu had suffered through being in the hands of bad kings, the last of whom, by name Jigi Adamu, eventually fled into German country to escape the penalty of past misdeeds. Then his son Jappo, a fine-looking man, whose pale skin and chiselled features spoke of a pure origin, proving himself loyal to us, was made chief of Malabu by the British Resident. Though only twenty-five years of age, he had by his loyal and upright character gained our sympathy and confidence. All this was distasteful to the Emir, who soon determined to get rid of him. Accordingly, he sum- 
moned several of the Malabu people to Yola, and three of these men were seen to enter the palace, pass through the hall of waiting and go on to a private room, where the Emir received them. After asking questions as to what was happening at Malabu, he bent forward and said, "Why do you keep a chief I do not like-why don't you kill him?" And they answered, "Very well, we also do not care for him." It was not long before an opportunity offered itself. Jappo went out into his district to collect the taxes for the Government, and one day arriving towards evening close to Vanga Malabu, which is built on a rocky eminence, he took up his quarters for the night in some huts on the ground below. Vanga Malabu is situated in a country much broken up by rocky hills and kopjes, and consists of groups of conical mud huts placed wherever the ground will allow of it. Sometimes the villages of these pagans are built on the kopjes themselves. On the arrival of Jappo the village assumed a hostile attitude and refused him food for his people. At daybreak a crowd of men, armed with spears, came down the slopes to attack him. Whereupon Jappo, turning round to his men, who were making ready to fight, called out "Lay down your spears; we serve the white man who loves peace." Then he left the compound, carrying no weapon, to meet his foes. The next minute he was struck down and hacked to pieces. A brave follower behind him was hit in the breast, but withdrew the spear and killed his assailant, both falling dead the same instant. However, the enemy proved too strong, and fourteen of Jappo's band were overpowered and killed. As soon as Jappo fell the chief murderer cut off his head. Then his heart was cut up into little square pieces and distributed amongst the assassins. The flesh was stripped off the body and eaten, while the head and arms 
were sent into Vanga Malabu, where the latter were used as drumsticks during a night of revelry and dancing.

His blood-stained clothes were tied up into a bundle to be sent down to the Emir. Then under cover of the darkness this bloody token was brought into Yola with the message- "The desire of thy heart is fulfilled," and the Emir, getting up from his Court, retired to receive the messengers of death as he had done once before, and he dismissed them, saying, "Go back and rest in your village." Eventually six of the murderers were captured and hanged, each in his own town. This is the story of the crime which brought the Emir to his fall.

August 5.-Disappointed to find that I cannot get dollars * here, as the Governor has now forbidden their circulation, but the manager of the Niger Company has promised to try and get them for me at Garua, so I shall await his return.

August 8.-I am laid up with fever; temperature 107. August 9.-Convalescent.

August 10.- Left to stay a night with Boyle at Yola, where he has an office. From the barracks it is rather a tedious journey; a leaky canoe takes one over a marsh about a mile in width, and then one has a journey of another mile of sloppy marshland, but of course this is only in the rainy season. On the Yola side of the marsh I was met by the Eurema (a title similar to our " Prince of Wales"), the Emir's eldest son, with about a hundred horse, who escorted me up to Yola. The Eurema went

* An Austrian coin of 1820, stamped with the head of Maria Theresa. Somehow or other, through Tripoli traders, it came to be the only piece reckoned with by the natives of Africa, so the French for convenience kept to it, making it at a cost of about 1.30 fr. each. $-\mathrm{E}_{\mathbf{D}}$. 
first; then came the band, aligatas and drums; then myself, and on either flank troupes of horsemen, who at intervals would throw up and shake their closed fists in the air by way of salute, crying out at the same time with hoarse voices a welcome to Yola, while in front more troupes of horsemen would gallop forward and spread out like a fan, and then return at a breakneck speed to rein their horses up before the Eurema. The varied coloured burnouses all added to the effect, which was very picturesque and inspiriting.

There is notbing to be seen in Yola. The huts and compounds are much hidden by young trees, which have originally sprouted from the sticks to which the zana matting was tied, and consequently one gets no clear or open view of the town. And there is much maize and gero grown between the compounds themselves, and this gives a very untidy effect.

The population is about seven thousand, but the birthrate is very low ; in fact, the Fulani here are an effete race. There is hardly what I would consider a typical Fulani here, that is, pale-skinned like the Borrero, or Bush Fulani, whom I consider are typical Fulani. From the Emir down they are all as black as one's hat. They claim to have come from Melle; if this is so, they must have intermarried very much with the pagans. And they do not speak the proper Fulani tongue.

The Yola Emirate, as far as its history can be traced, is of comparatively recent origin. Four-fifths of the Yola Province is composed of pagan tribes; the remaining fifth, which lies in Adamawa, is a Fulani settlement which was founded by a Mallam, named Adamu or Mordibo, in the early part of the nineteenth century. The origin of this matter is shrouded a good deal in mystery. However, it is known that Adamu was born 
about 1780, and as chief made his headquarters at Gurin on the River Faro, thirty miles east of Yola. Besides being a soldier, he had a great reputation for learning, and he soon collected round him a large Fulani following, mostly immigrants from Bornu, while he acquired a great influence among the Cow-Fulani, who were settled among-and subject to-the powerful tribe of Batta pagans, who at that time occupied both sides of the Benue for a considerable distance. In 1807 he went to Sokoto and was given a flag by the Emir, Shehu bi Fadio. This flag is now in the present Emir's palace, quite white, but if held up to the light texts from the Koran are visible upon it. After this he returned to Gurin and was acknowledged by the Fulani as their head.

In 1840 he moved from Gurin and made his capital at Yola. During his rule not much progress was made in throwing off the pagan yoke, a radius of thirty miles from Yola town representing the limit of Fulani conquests at the time of his death in 1846.

In the west he failed to subdue the Bashima, who, being mounted like the Fulani, proved a match for them. His expeditions into this country might be regarded more in the nature of hurried slave raids than anything else. $\mathrm{He}$ did not go far south himself, but his three lieutenants penetrated as far as Gaundere, Kwoncha, and Banyo. Mordibo was succeeded by his eldest son, Lowal, under whose rule Fulani influence was extended over a vast area, now known as German Adamawa. During his reign he visited Sokoto. He appears to have been a good king. Lowal died in 1872, and was succeeded by his brother Sanda, who was born in 1825. During Sanda's rule no further extension of Fulani influence appears to have taken place, since, being a scholar, the greater portion of his time was devoted to education, he himself conducting and instructing personally his schools. 
In 1890 Sanda died and was succeeded by Zubeiru, a son of Mordibu Adamu, born in 1837. Though Zubeiru was noted for his personal bravery, his Emirate suffered under his harsh rule, while his fanatical hatred of the white man brought his downfall in September, 1901, when he was driven out by a British force. He fled into German country, where he was defeated by the Germans, eventually being driven back to English territory in 1902 . All efforts to get into communication with him failing, a force left Yola in February, 1903, to attempt his capture. He was attacked, but managed with six men to get away during the fight, escaping to the country of the Lala pagans, who were the hereditary enemies of the Fulani. A day or two later he was discovered hiding in the bush by the pagans, who before he and his party could make good their escape killed them to a man. The next Emir, Bobo Amadu, born in 1843, and last surviving son of Mordibu Adamu, was appointed in 1901. Both he and his brother, Zubeiru, were sons by a pagan (Marragi) mother, but Lowan and Sanda were pure Fulani. I have already given a history of Bobo Amadu.

The trade of the Province consists in gum, gutta, beeswax, indigo, and shea nuts. This month and the next (August and September) are the season of the latter. The Niger Company are taking on the average six tons a week. Besides these products, guinea, maize, rice, and wheat are all grown. Yams are grown by the Verre pagans. The principal industries of the Fulani are farming and the rearing of cattle, horses, sheep, and goats, while cloth-weaving, dyeing, and the manufacture of "Morocco" leather must also be taken into account. A great deal of kola nuts come from the Cameroons, from Gaundere and Banyo chiefly, and are sold at five shillings per hundred in the Yola market. 
Iron ore is plentiful, and is smelted by the pagans for spears and arrow-heads.

Our method of ruling the country is to do it through the Emir, who is helped by his chief adviser, called the Waziri, and also a council consisting of twelve to fourteen men under the chief Alkali and two others. They have the power of inflicting the death sentence, and the mode is beheading. The victim is first stunned by a blow from behind by the executioner, who then proceeds to saw off his head. For offences other than murder the sentence may be a flogging. The victim is driven round the market on a black donkey, followed by the castigator, who is not allowed when giving the lashes to raise his arm above the shoulder, and to ensure this he is made to hold cowrie shells under his arms.

August 13.-Back again in Yola. In the evening I had a rocket display which ended badly, one of them bursting at my feet, giving me a terrific blow on the left instep, which laid me up for the next ten days. During which time I managed to get another attack of fever with high temperature, 107.2, and severe ague and vomiting. I think I must have contracted this kind of fever in the Cameroons, as the doctor here says he has never heard of it in these parts.

The manager of the Niger Company, being unable to get me dollars at Garua at the price I quoted, Barclay has given me permission to collect them in Yola, and I have bought over a hundred from a Hausa trader here at the ruinous figure of $3 \mathrm{~s}$. $3 \mathrm{~d}$. each; but they are new ones, and that makes all the difference. There is a regular trade in these dollars between Garua and Lokoja, where they are sold at 3s. 6d. each, for making into rings and bracelets. At Garua the price is 2s. 6 d. The present trader had more than three hundred of them, 
and is on his way to Lokoja; the trade must be a pretty lucrative one.

August 24.-My foot well enough to move into my old quarters at Gimeta, but a stick is necessary, and I have to be lifted into the saddle.

Sir William Wallace arrived here on August 17th, and the next morning officially appointed the new Emir, Mahamedu Iya, nephew of Bobo Amadu. Sir W. Wallace sent me a very kind letter through his secretary, saying he was sorry I was laid up and offering to help me in any way he could. In fact, nothing could have exceeded the kindness shown to me by all the officials in Yola.

August 25.-Made a start at last for Maifoni, with thirty-two carriers in all.

Arrived Geri, in two and a half hours. It is a Fulani town.

August 26.-Stayed Geri. Heard the shocking news that the small Government launch, which took Barclay down the river a few days ago, struck a rock and sunk about two days from Lau, and the poor fellow was drowned. Apart from the extreme kindness which Barclay showed me while at Yola, he had a charming personality, and another sad part of the affair is that he only married the last time he was home on leave.

August 27.-Arrived Wuru, in four and a half hours. Leg still painful.

August 28.-Gellen, four and a half hours. A tsetse belt exists along the River Maoi, about four miles from Gellen. I greatly fear that San Thomé has been bitten by the fly, probably when coming up the river from Ibi. $\mathrm{He}$ is in a pitiable state now, has eaten nothing for the 
last two days, and does nothing but sleep, waking up after sundown to wander aimlessly about like some unhappy spirit. One is powerless to cure or give relief.

August 29.--Stayed Gellen owing to leg.

August 30.-Arrived Song (Fulani chief), four and a half hours. One and a half miles from the town one has to cross the River Maio again, about thirty yards wide. To-day the water reached to one's middle.

From Song onwards the country becomes broken with

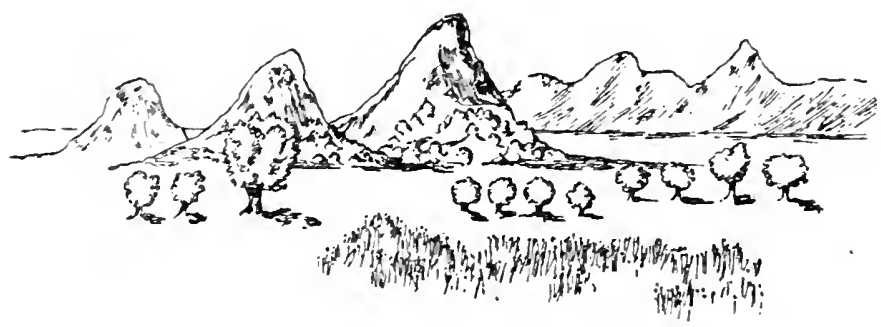

Hills at Soxg.

small ranges of hills like those in my sketch, clothed halfway up in trees, and then bare rock to their tops.

August 31.-Road from Song to Goila (four and a half hours) very stony and undulating. There is much cattle at this place.

September 1.-Arrived Dua in four hours. No supplies. Here begin the Kilba pagans, who live in the rocky hills. On my way here, soon after leaving Goila, we passed several Bush Fulani camps, with a large amount of cattle. From one of the settlements several women came out to sell milk and butter. One woman, a typical Fulani, was extremely handsome, with pale skin and very regular features, and long black hair which hung down on each 
side of the face in twisted ringlets. The ears were hung with many heavy brass rings. I took a photograph, which I hope will come out well.

September 2.-Pella, in three and a half hours, a small station at present in charge of a non-commissioned officer, Sergeant Hammond, R.E. Curiously enough, he was with Lugard during his tour in Bornu in 1904, and met Gosling at Yo. He comes from Bishop's Stortford, and knows all the Gosling family. The station is situated among rocky hills.

September 3.-Had breakfast with Sergeant Hammond. How resourceful these non-commissioned officers are! The first dish he gave me was dry biscuits well soaked in milk and flavoured with a little nutmeg. To prevent the soaked biscuit from rising a small stick was spanned across the cup. It was really excellent, and I never realised, till he told me, that it was only made out of ship's biscuit. After breakfast I managed to limp off with him to the market. On the way we heard most unearthly cries coming from a compound, and at the time I thought they were those of some animal in pain. We looked over the zana matting of the compound, and then we realised that a most interesting "ju-ju " palaver was being enacted. The subject was a woman, apparently demented. On the ground lay a sheep on its side, with its throat cut, the blood flowing into a hole which had been made in the ground. The woman, on her hands and knees, was beating the ground frantically in front of the sacrificed sheep, while the "ju-ju" man, also on his hands and knees, was lapping up the blood, and performing between the laps silent incantations by means of gestures. This form of "ju-ju" is practised by both Hausa and Fulani, and is known as Burri, and is only made use of in cases where 
the patient has become demented. My camera fortunately was at hand, and I took photographs.

At the place where I stopped for my midday meal after leaving Pella, a rather curious coincidence happened. I have already spoken of San Thomé's sickness, and I fear he gets thinner and weaker every day. The only thing I can get him to eat is liver, and I felt it was absolutely necessary to try and buy a sheep at the earliest opportunity; in fact, I was in want of fresh meat myself, having for the last week lived on tinned meat and the lean fowl of the country, a tasteless dish which one gets very sick of. As soon as I stopped I gave orders to one of my soldiers to go on ahead and tell the king of the town my wish. His answer was that at the best he might be able to get a goat from the chief, as the village was a pagan one (Kilba) and poor besides, and the Kilba did not possess sheep. However, I sent him off, telling him to do his best. Hardly two minutes had elapsed when he came running back, saying that he had distinctly heard the bleating of sheep in the distance coming along the road, and that it must be a Hausa caravan, with sheep, on its way down from Bornu. I listened but at first could not hear anything. Then, a few minutes later, I distinctly caught a faint sound of bleating, and I almost exclaimed in the words of the Prophet, "What meaneth then this bleating of the sheep I hear in mine ears?" when presently a flock of sheep, with their shepherds behind, came in sight. It did not take long to strike a bargain, and I took away with me a fat and lusty ram, while all my followers cried out "Allah, the only God, is guarding thee!"

An escort of two soldiers were given to me by Sergeant Hammond, as the road about Chibuk is not altogether safe. Though these people were "palavered" about two 


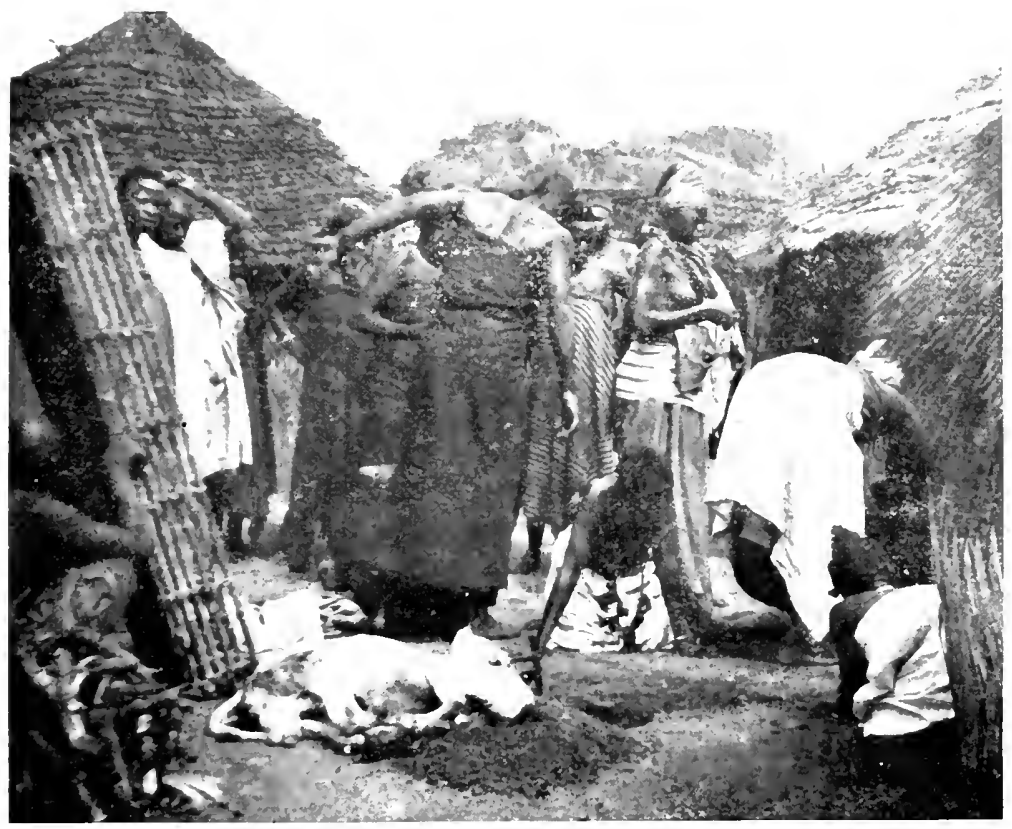

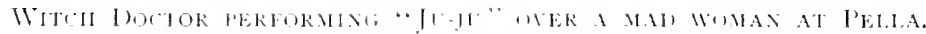

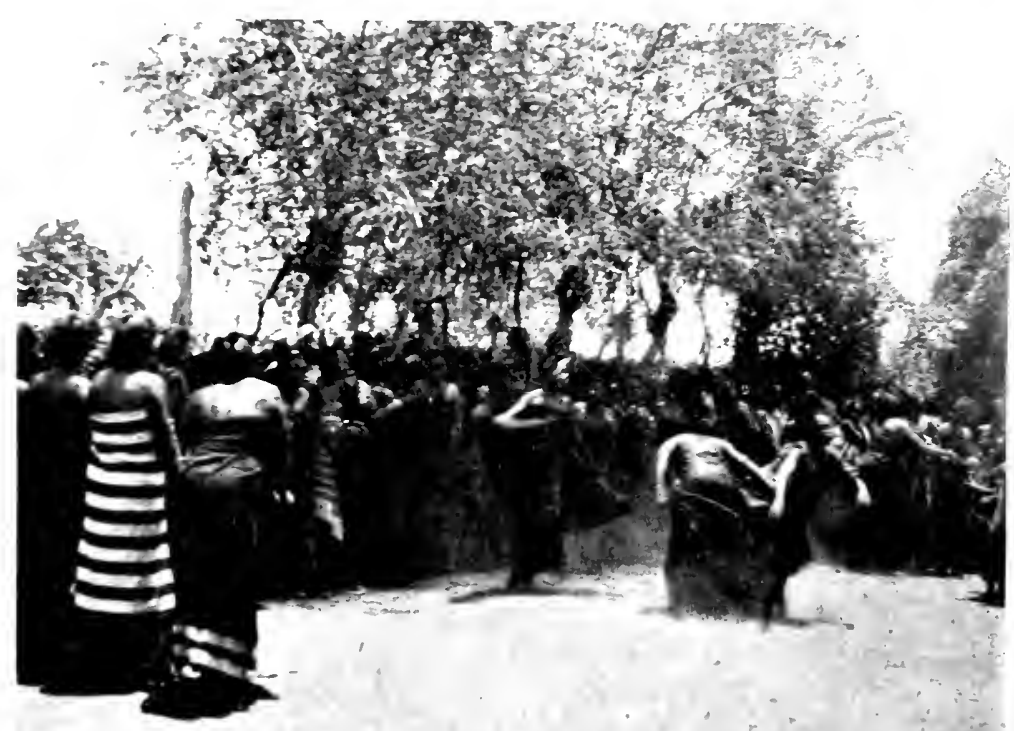



years ago, they are still truculent, and have returned to their old life again in the caves. If the road is unsafe now, how much more so must it have been in 1905 when Talbot passed down it without an escort, my application for one having been refused. Then the Chibuks had not been punished and Pella as a station did not exist.

Reached Myili in four and three-quarter hours. I sent to the chief of the Kilba village, which is some way off, asking him to bring in supplies, but he refused. If it had not been for my bad foot I should have gone myself, and brought him in and taught him a lesson.

September 4.-Made a late start owing to heavy rain, which lasted pretty well all day. The road the whole way was a running stream.

I made a camp close to Jabba, a Kilba village lying at the foot of a range of rocky kopjes, two and a half hours' march from Myili.

September 5.-A typical pagan gathering witnessed the striking of my camp from a respectful distance, squatting in rows on the rocky ledges of the hills, like so many monkeys. These Kilba pagans have a distinct type. The men are poor in physique, but the women are splendid. Like other pagan tribes, these people have intermarried a great deal, and this probably accounts for the deterioration in the men. They are great farmers, growing gero, maize, ground nuts, and a certain amount of cotton. Their mode of salutation is by clapping both hands several times together. The Batta pagans greet one with both hands pressed against the temples, the fingers encircling the forehead.*

* Boyd was always very much interested by the various, and in many instances curious, forms of greeting obtaining among the tribes of Africa, and in vol. i. p. 272 of his book he gives several examples, throwing out suggestions as to their origin.-ED. 
River Maio, in one and a half hours. Here I have had to make camp, for the river is so full and the current so strong that passage is at present impossible, and I shall have to wait in the hopes of the water falling. The total absence of road-clearing, bridging of streams, and providing canoes at unfordable rivers in the greater number of the provinces of this Protectorate is really lamentable; and though this river is within two days of a station and native towns within three hours from either bank, nothing has been done. In many places one has to force one's way through long, standing grass. I know I have already expressed my opinion on road-making in Africa, taking rather the opposite point of view; but I think we go too much to the other extreme of what the Germans do, and I think there might be a happy mean.

September 6. - The first thing this morning I sent out some of the carriers to reconnoitre, and after some time they came back saying that we could cross the river, the water at the deepest part being up to their foreheads. The headman told off four of the strongest to carry me, and it was really wonderful how they did it. The tallest man carried me on his shoulders, and the other three held me on either side. At the deepest part, where the current was strong, they disappeared altogether, and the same thing happened to the men who were carrying my loads. The effect was most mysterious: nothing but the boxes were above the level of the water. After gaining the other bank (total width of river about eighty yards) we had to march through about half a mile of bad swamp, where in one place my horse sank into the mud up to its shoulders, and I had to roll off. After passing the swamp we had to cross another branch of the River Maio, but this was not quite so deep as the first stream. But after crossing there was some distance of swamp to get over. 
At the other side the headman of the King of Womdeo, with a number of men, met me. They were very useful in giving help to my carriers, and afterwards they played me into Womdeo with their drums, a distance of five and a half miles in two hours.

The Marragi are interesting pagans, a healthy and clean-made race, and their adornments give them barbaric splendour. They are very dark, almost coal-black. Heavy necklaces of blue and white beads hang round their necks, and broad armlets of twisted iron are worn above the biceps; these are only worn by the young men who virtually own young girls at the houses of their mothers, but who have not yet reached the marriage state. As soon as they marry, the men take off the armlets, replacing them by heavy brass wristlets. Cows, sheep, and the black Bornu gown are given as marriage presents. The Marragi wear no clothes, except in the case of the men, who put on black, tanned skins, cut behind into fantastic tails. The very young girls wear a fringe in front, consisting of rows of wooden beads strung together. As soon as they reach the age of puberty or are married, this is replaced by pieces of iron strung in one row with pointed ends which are curved and stick out, giving one the idea of protection against molestation, much as barbed wire is used. Lip ornaments consisting of long pointed pieces of iron hang down from the lower lip, and are generally worn by the women. The Marragi build their villages close to the base of rocky kopjes, which are often to be found in this part of the country standing isolated in an otherwise flat country. During the Fulani rule over the Marragi country these rocky hills, which lay close behind their villages, were retreats against which the efforts of the Fulani horsemen proved futile. The Marragi speak a distinct 
language from their near neighbours, the Kilba, with whom they do not intermarry.

September 7.-Arrived Musa (Kilba), in four and a half hours.

September 8.-Chibuk in seven hours. About half an hour from Musa is Gokombi, which marks the limit of the Yola Province in this direction. The road to Chibuk was bad going, with much mud. The Chibuk hills are a low range of kopjes from 100 to 200 feet in height and lying in the form of an arc, the east end of which rests on the Yola-Maifoni road. These hills are very rocky and have many caves in them, some large enough for a horse to stand upright. They were inhabited by the pagan tribe called the Chibuks, who from these stony strongholds were in the habit of committing outrages upon wayfarers, until they were turned out by us a few years ago. Now at this time they are living in villages on the low ground, a step in the right direction towards the possibility of the white man's getting into touch with them. At their village to-day I witnessed a funeral ceremony of an old woman who had died two days ago. During the morning singing and dancing to the accompaniment of drums went on in the compound of the house in which the body lay. About midday the body was taken outside the village to an open spot, where it was laid out upon a piece of zana matting on its side under a rough grass shelter, open on one side to the view. There were many hundreds of men and women present. A short distance from the body a large ring was formed, where young girls with shapely limbs danced and sang to the accompaniment of drums. Their bodies were smoothly and lightly painted with red earth, and they were beautifully adorned with brass armlets and bracelets and bands of woven 
cowrie shells and beads round their legs at intervals, while heavy strings of beads, chiefly blue and white, hung from their necks. Their hair, matted into tight tufts all over the head, was also covered with red earth. It was pretty to hear their young voices. After a time two stalwart men, naked except for their loin skins, stepped out from the throng and carried the body to a grave which had been dug not far off. The husband of the dead woman, an old man followed behind. Then the body was put into the grave, lying on its side, and the grave filled in. Next the old man stepped forward and harangued the crowd, telling them of the virtues of his dead wife, that he was still living but would eventually come and lie beside her as he had done during her lifetime.

The young men of this tribe wear a metal ring about the size of a half a crown in the left ear. When they get married this is taken off. The young women wear two rings in the same ear.

The Chibuks, though they have a distinct dialect, speak in many cases Kanuri. Before the coming of the white man they were frequently raided both by the Kanuri and Fulani for slaves, and there is not a doubt they made these rocky kopjes their strongholds in consequence, where the Kanuri and Fulani horsemen were to a great extent powerless to pursue them. In type the Chibuks are small-featured and round-faced, with deepset eyes, snub noses, and prominent foreheads. The tribal marks are three semicircular gashes on each cheek.

September 10.-My diary to-day will, I fear, be full of "grouses," but I think I can say it is rare that I ever indulge in them. The more one travels in Africa the better one acquires an even temperament, but perhaps a "game" leg like I have now helps to throw it out of 
balance. Soon after leaving Chibuk the road became practically impassable, and for at least five miles I had to wade through a deep morass. My horse had literally to plunge the whole time, and the story of the Kelpie's Flow was brought vividly to my mind. Twice the horse sank up to its shoulders, rolling me off and sinking me in deep mud. I struggled on in this hazardous fashion, the sweat pouring from me, for three miles; and then I gave it up and sent forward for some of my strongest carriers to carry me. This they did for the remaining two miles. This is one of the main roads to Bornu!! It is in a deplorable condition; not only the roadway itself, but at many of the resting-towns the rest-houses, or collection of huts for the convenience of white men passing through, which should be kept in good condition by the chiefs of the different towns, are in a ruinous state. This state of things should not be in the Protectorate.

At last we reached Gumsuru, a Marragi town, after a march of six and a half hours. I feel pretty glad to have got here, after the trying experiences of to-day; my foot is in a very painful condition, but I must struggle on somehow. If this part of the country were properly surveyed I am sure that the big swamp, which I have just spoken of, could be avoided by making a detour, but of course it would possibly mean the lengthening of the day's march to a certain extent.

Gumsuru is a large, scattered town. On all sides there are nothing but large tracts of standing gero, from out of which only the roofs of the various settlements can be seen.

September 11.-Reached Girrni, a large Beri Beri town, the first on this road, and three days from Maifoni.

September 12.-Wapti, in four hours. 
September 13.-Mussoba, in four and a half hours. About one hour before getting to Dellwa, the king and ten men, all mounted, met me and brought me in. They wore their best clothes and looked very picturesque. The king has great proportions, and I should say he must be an eunuch.

September 14.-Arrived Dallwa, in three hours; much water on the road. The King of Mussoba with his horsemen came with me. In this country the people make plenty of the blue dye, the favourite colour for their gowns. It is made from the leaves of a small-leafed plant. They are picked and pounded well, then put in a hole lined with burnt clay and filled with water. After about seven days the leaves produce the blue dye in which the clothes are dipped. The Hausa name for the plant is baba.

September 15.-Early this morning the Kachella, Bukar Karga, who is now posted at Chibuk, rode into the town and saluted me. He is the same man I caused to be flogged at Maifoni in 1904 . As we met the remembrance of this seemed to flash through both our minds, but the next moment it had gone and we were shaking hands. A short time after the whole town turned out to play before me in the large open space in front of my tent, which is pitched under a shady fig-tree. The band consisted of drummers, who led the people after them, and by marching two or three times round formed the arena for the games. Wrestling was the order of the day. The drummers were never silent, marching round and round and only pausing when a would-be wrestler came into the ring to challenge an antagonist, which he did by going down on his hands and running round the ring in monkey-like fashion. 'Then, finding an opponent, the two 
met and shook hands and then marched behind the drums. The next moment one was conscious of an extraordinary personality following these men. His face was the image of Beerbohm Tree's Mephistopheles, but more massive if anything, while his gestures, accompanied by grimaces which showed a set of large teeth all reddened with the stain of kola, greatly enhanced his satanic appearance. He was big of stature, and the effect was increased by his long black gown. Every now and again he clamped his arched hand with fingers spreading like claws upon the head of one of the wrestlers, and at the same time to the accompaniment of the drums, urged him to be brave. Then he would stop and almost amble along beside the man, and the next moment break out into another invocation. I could not keep my eyes off him, he fascinated me immensely.

There were some extremely good wrestlers. Their mode differs slightly from that of the Hausa. The loin cloth is caught hold of, a move which the Hausas will not agree to. Every time a victor was proclaimed he ran and knelt at my feet to receive a coin; then he went to the Kachella sitting opposite to me, who threw him some kola nuts. The champion wrestler of course provoked roars of applause, and did it so happen that the victor was the favourite amongst the women, he was hailed by them with shrill cries that went up from a hundred throats.

More than once I thought the "show" would fizzle out, although the drummers went on beating incessantly, the sweat pouring from them; but there was always some one to come forward to keep things going. This time it was a cripple beggar, who showed himself to be quite a fair grotesque contortionist, jumping round the ring in a sitting position with one leg resting on his 
shoulder. He was a well-known figure to the people, and they all showed a kindly pity towards him, for, when his little "turn" was over, he received much recognition in the shape of kola nut. Altogether, the nut played a prominent part in the proceedings; not only was it the men's reward for prowess in the fight, but the women held some carefully wrapped up in their clothing to give to those who successfully begged of them. At one time it would be the drummers who would stand in front of a batch of women closely packed, and drum into their ears in order that some recognition should be given them, and it was amusing to watch how each woman pondered how she could get off by parting with the least possible amount of kola. In this direction "Mephistopheles" was one of the most successful, and the capacious pockets in front of his loose gown bulged with cowrie shells and kola. His knitted brows and deliberate gestures that emphasised his talk seemed to cast a spell over the women; in fact, the business of this man seemed to be to enact the part of the Spielmann. I tried to get a reason for this; but all the natives I asked could not give me one, but only said it had always been so. After the wrestling bouts had finished, the crowd began gradually to melt away, but a large batch of women remained, and under the auspices of "Mephistopheles" spread themselves out in a semicircle for the purpose of giving an exhibition of their dancing. Soon there fell upon the ears a chorus of shrill voices accompanied by a clapping of hands, and walking up and down in front was Mephisto, who would now and again pause to chant an invocation, which was echoed back again by the women nearest to him. While this was going on, two women, one from each end of the line, would come out, and, catching up their flowing garments in one 
hand, dance towards each other, and when close, suddenly turn about and in the same moment bump each other heavily upon the buttocks. It is a curious dance, and by no means elegant.

The mode of hairdressing amongst the Kanuri women - the crown closely plaited and terminating in a thick, blocked fringe-gives them a very classical appearance, and but for the hideous custom of inserting pieces of imitation coral or round bits of wood in one nostril, which has the effect of splaying out the nose, they would really look quite handsome. Again, the custom of reddening their teeth is not beautiful, but in most cases it is only a temporary process towards whitening the teeth. To commence with, the teeth are rubbed over with the juice of tobacco flower, and then kola nut is eaten, which has the effect of reddening them. They are left in this state for three or four days, and then the stain is cleaned off with a stick.

September 16.-In the evening a very nice letter came from Brocklebank, saying that if I liked to come in to Maifoni there would be a house ready for me.

September 17.-Left for Maifoni, and after a hot march of three and a half hours arrived at the Barracks about eleven o'clock. I had intended to find a suitable camping ground outside the station; but the whole place looked so changed that I could not find my bearings, and, added to this, a heavy tornado was about to break, which drove me to seek shelter in the Fort. Here I was warmly welcomed by Captain Knox (O.C.) and Lieutenant Thompson. The former offered me his house, which is the one in which poor Pickles died, but it has been enlarged, and the flat roof replaced by a zinc 
one; in fact, the whole character of the Fort has been destroyed by hideous zinc roofs on all the buildings, and the walls outside are partially hidden by young trees. In the evening I was asked to a dinner, which included all the white men with the exception of Hewby and the doctor (Alexander). I was surprised to hear from Brocklebank that the French had taken Wadai, and that the road now is perfectly safe. This, of course, will make my journey much easier, and I shall go now by Fort Lamy.

On my arrival I found two telegrams awaiting meone from José saying that he had left Kano with five camels on September 11th, and the other from Herbie asking, "When home?" and my reply was, "Well; not yet."

As soon as the camels arrive, and I can get started from here, the journey should not take me more than three months to the Nile.

September 18.-Went to look at Pickles' grave. The mud wall of the graveyard is in a very dilapidated condition, in places being almost washed away. The arms of the cross itself have fallen away from the straight line, while a stucco pillar has been made behind the body of the cross to serve as a prop. This has done away with the elegance of the beautiful cross. The grave itself is marked by a low border of cement, while the inside is floored over with cement. This does not look in keeping with the cross.

There is another grave now, that of an Assistant Resident named Stewart, who died in 1906, and in November, the same month that Pickles died in two years before.

September 19.--Have made friends with the foreman 
of works, who is running up buildings here, and he has promised me one of his men to help me put the cross to rights; in fact, I shall have the whole cross down and every section recemented, and I shall also take away the cement flooring on the grave itself, leaving only the border; this will make it look less heavy and be much more in keeping with the graceful cross. I have also engaged labourers to build up the mud wall. This they can begin on at once, as the rains have finished. The country looks very different from what it did when I was up here last, in the month of November, 1904; now all the mimosa-trees are a vivid green, and over a flat country burnt brown as far as the eye can reach the dark splotches of thick-leaved fig-trees make arresting landmarks. The little river is full just now, and at points the current is quite five miles an hour.

September 21.-Left the Fort to make a camp about half a mile to the east, and on the way towards the range. I have chosen a good place, and there is a nice spot, too, under a shady fig-tree for my tent. I am also putting up three houses of zana matting-one as a kitchen, one for the boys, and another for José when he comes in. I thought at first I should have difficulty in commanding labour to make the camp; but luckily the headman of my carriers, who brought my loads up from Yola, has come forward with the number of men I want. Brocklebank tells me that these men are "waiting on me," hoping to get employed again when I leave Maifoni ; they have already refused an offer of Government service. Brocklebank is a very good fellow, and able too, a hard worker, seldom leaving his office much before dark. He is liked by all the people. Though it is only his first tour in the political service, it is re- 
markable what an insight he has got into his work, which of course every year gets more complicated.

$\mathrm{He}$ is a man with hobbies too, and that, I think, is everything out here. $\mathrm{He}$ has three most serviceable bullock wagons which he brought out with him from Europe. Each can carry about two tons, and is drawn by ten oxen. It is no child's play having to break them in ; the Bornu oxen are not used to harness, since they are either ridden or treated as beasts of burden. Just outside the station he has quite a farm, and his herd at the present moment numbers something like fifty head, a magnificent lot.

My distance from the station gives me the opportunity of a walk in the morning, and this I take as far as the graveyard to see how the new wall is getting on, and then in the evening I ride on the road towards Geidam, always in the faint hope of meeting with José, but the sun goes down a red ball in the west, the sandy road in front looks whiter than ever, and down it no camels wend their way. To effect a junction of one's forces over long distances is always difficult, and until it comes about one cannot help feeling anxious.

September 25.-While sitting outside my tent this evening I caught sight of one of the official messengers coming towards me, carrying the usual long, blue envelope. I opened the letter, which read as follows :-

\section{MaIdUgari, 25 September, 1909.}

SIR, - aS I understand that your sojourn in this neighbourhood will extend over a short period, I consider the opportunity too good to be lost for clearing up a point that has troubled the administration at headquarters, and upon which other distinguished travellers have disagreed, and I venture to present to you a problem that interests 
the travelled world, in the confident belief that your wellknown insight into abstruse questions of this nature will find an easy solution to it.

As you are aware, Barth, in the fifties, wrote of this country that the Kanuri were a cognate element of the Bornu Empire in the thirteenth century. Nachtigal in the seventies wrote that the name Kanuri was of relatively recent date, they were not an original tribe, but a collection of people. Which of these travellers is right in his research?

I have, \&c.,

(Signed) W. P. HewBr.

I took a considerable amount of trouble to answer this as far as I could, besides sending with it a private note.

September 29.-I have received no reply or acknowledgement from Hewby to my letter of the 25th.

From native information I have been able to get some interesting notes on the history of the Kanuri people. The numerous races in Bornu made Nachtigal come to the conclusion that the Bornu Empire had been composed of nothing more than " a collection of peoples," and that the Kanuri were not the original builders of the Empire. Barth, on the other hand, held the opposite view-that the Kanuri were cognate with the Empire, and I cannot help sharing his opinion, when the following facts are considered.

The Kanuri are supposed to have come from Yemen to Fezzan and then penetrated into the Sahara by way of Shirhit.

In the thirteenth century they founded the capital of their "Empire" at Birni, the ruins of which are still extant, on the right bank of the Yo River, and a two days' 

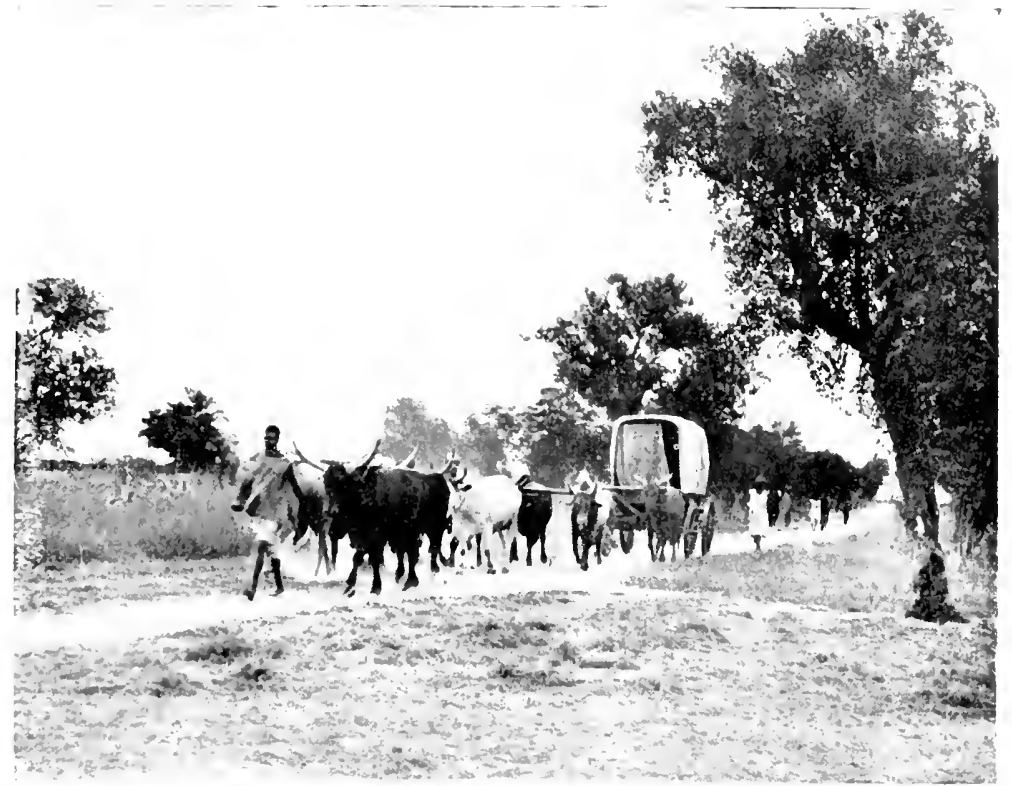

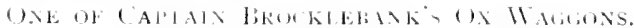

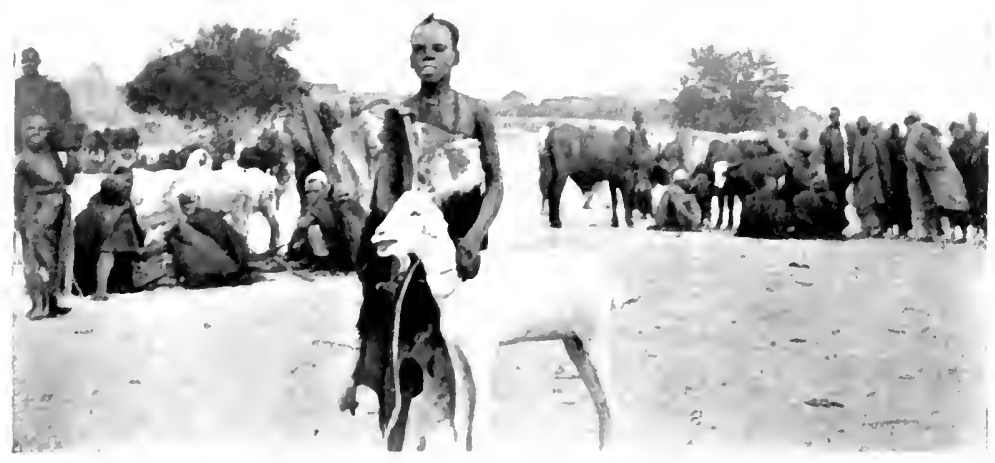

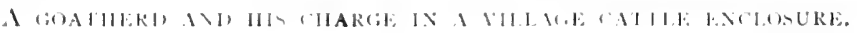



march to the east of Geidam. When considering the distribution of the races in Bornu at the present day there seems to be no doubt that the Birni dynasty spread over the western and southern portions of Bornu, and to within five days of Kano, subjugating and intermarrying with the following tribes-Ghamerhgu, Mandara, Kotoko, Marragi, Baliwa, and Manga. All these tribes paid tribute to the Kanuri. It is quite probable that the Manga were the forerunners of the Kanuri race, and settled in the country before those who founded Birni. Then in the country lying near the western shores of Lake Chad we find several local races of a different element, who, to my mind; mark the extreme western distribution of the Kanembu race, with Kanem as the proper centre. They are the Tubu (Yo River), Mobbur (south bank Yo), Kurio, and Kwoyam. According to native information, which I have obtained from true descendants of the Birni people, the above races were in the land before the founding of the Birni capital, and therefore are a separate element from the Kanuri. Besides, the method of hair-dressing with the women of these races is entirely different from that of the Kanuri, and consists in the hair being trained in a long curtain-like fringe all round the head, identical with the Kanembu method. Also we find that these races speak Kanuri imperfectly. When the Fulani raid under Usman from the West attacked Birni in the reign of the Kanuri king, Maiarri, the ancient capital of the Kanuri was sacked and destroyed with great bloodshed and the remnants of the inhabitants fled to Gashagar, where, according to report, they stayed for seven days, afterwards going south to Mongonnu, in the neighbourhood of which town they made a settlement.

At the same time the Kanembu Mallam, Laminu, led a crusade from Kanem into Bornu against the Fulani. For 
some time he sat down at Ngornu, but was eventually driven from there, and penetrating into Bornu attacked the Fulani and drove them out from Birni, just forty days after the occupation of the capital by the latter. After this event Laminu founded and built Kukawa. During his reign the remnants of the Kanuri from Birni came under his protection, and they built for themselves the town of Ghamberu, near Kukawa, where they remained until it was broken by Rabeh.

With the settling of Laminu at Kukawa the true Kanembu element was introduced into Bornu, and except for intermarriage which took place between them and the Birni remnants, the Kanembu must be looked upon as a separate element from the original Kanuri.

As regards the origin of the Buduma of Lake Chad, tradition says they were brought into Bornu by the Kanuri during the Birni occupation, and were most probably their slaves; that after Birni was destroyed they fled to the Shari, where they endeavoured to establish themselves in the neighbourhood of Gulfei but were eventually driven away and compelled to seek refuge on Lake Chad, where their descendants remain to this day. The Buduma canoe, though built of rush, strongly resembles in shape the Kotoko canoe, which they probably took as their model.*

I have not seen the Birni ruins, but I am told that they show that the buildings must have been remarkably strong and good in structure, and that the bricks to-day are as good as on the day they were first made. I have seen a specimen at Maifoni, which is well shaped and as hard as iron; no brick like it can be turned out here.

* I do not now think this is correct. I have since been told that the Buduma came with the Mallam Laminu the same time as the Shuai people.-Avthor. 
The first question I asked myself was, how did a native race like the Kanuri get a knowledge of brickmaking which is the handiwork of a white people? And the answer seemed to me to be that in the days when Birni was built doubtless the people of Bornu were far more dependent on, and therefore in closer contact with, the Tripoli caravans than at the present day. Indeed, the Mallam at Kontogora, who is a true descendant of the Birni people, has borne me out in this solution. He says that a certain number of Kanuri obtained their knowledge of brickmaking from Tripoli, whence they brought with them the wooden frames necessary for shaping the bricks. He also told me the interesting fact that the clay was mixed with the blood of bullocks, which had the effect of binding and hardening it - a rather costly cement! but then in those days their herds of oxen were counted by the hundred. After the destruction of Birni, this art of brickmaking died out, perhaps because the Fulani took good care to kill all the brickmakers, who had reared against them such a formidable town as Birni.*

In conclusion, the distribution of the Kanuri and Kanem races in Bornu may be classed as follows :-

Races which the Kanuri sub-
jugated and absorbed by
inter-marriage. $\quad \begin{cases}\text { Mandara } & \text { KanembU. } \\ \text { Ghamerghu } & \text { Mobour } \\ \text { Marragi } & \text { Kurio } \\ \text { Kotolio } & \text { Kwoyam } \\ \text { Baliwa } & \end{cases}$

Probably the fore-runners of
the founders of Birni.

* There are buildings in Machena composed of bricks from Birni. It is said that the Machena people bought a large quantity from the Birni people.-Author. 
That the Kanuri are an ancient race I have no doubt whatever, and it is not to be wondered at that local races should not have sprung from the original stock, for there is a natural tendency with all pastoral peoples to lead a clannish and hamlet existence. Moreover, when regarding the Kanuri of the present day, especially the remnants of the old stock, there are evident signs of racial deterioration. The men of the higher classes are effete and degenerate. On the other hand, the women are exceptionally strong and healthy-looking, their birth-rate more than doubling the males, a condition that points, I believe, to a last "flicker" in an ancient race on the down grade.

The name Bere-Bere, which has been given to the Kanuri by the Hausa, seems curiously fitting, for in any business transaction the Kanuri far excel the Hausa in the way of "gaff," so much so that there is a common saying that the talk of five Kanuri is equal to ten of the others. Hence one could imagine how the Hausa, getting impatient of the Kanuri's talk, would exclaim "Bere-bere!" meaning in Hausa "Stop, stop!" Is it possible that this is the derivation of the name?

From an agricultural point of view Bornu is a rich country, with vast fields of "gero" and "dawa" everywhere. As soon as the harvest of gero is finished, the crop of dawa comes on.

In this land towards sunset a sight which is familiar at every village is the slow-moving clouds of dust which mark though they curtain from the eye flocks of sheep and cattle being driven into their zarebas for the night.

October 6.-About 3 o'clock this morning I was awakened by San Thomé, who was lying at the foot of my bed, growling and dashing out like a streak of greased lightning at some one outside. I raised myself up, rubbed 
my eyes, and saw a number of shadows in front of my tent, while behind them were swaying forms that suggested the heads of immense gargoyles. The next moment I heard the welcome voice of José, who had arrived with the camels from Kano. In the meantime San Thomé had done his best to take a piece out of José's finger.

The camels are all fairly good, but a little thin after their long trek, and two of them have saddle galls. Before I attempt to go on I shall give them a rest for about three weeks. I shall probably go out to Kondaga, about twenty miles from here on the Dikoa road, where I am told there is good feed for camels. On José's way through Bautchi, Major McClintock, the Resident, was very kind to him and gave him a letter to Temple at Kano asking him to help him in getting the camels.

When he arrived there Neild, the transport officer, helped him a great deal, selling him two of the Government camels, as he could only get three in the market. It was a bad time to buy camels, for, being the wet season, very few come down to Kano. The prices were from $£ 4$ to $£ 5$ each. During the rains the camels go to the north of Kano to the Damerghrum country.

I must also mention Major Booth, the Resident at Geidam. When José arrived there Booth at once gave him the rest-house to stay in, and had wood and water sent down to him. Such kindnesses are always a pleasure to remember.

\section{Notes on the Occupation of Bornu by Rabeh.**}

The first event of importance that marked the penetra-

* Rabeh, sometimes called the Black Napoleon, was a Furian by birth, and became the slave of Zubeir Pasha, the great slave-raider 
tion of Rabeh into Bornu was the sacking and destruction of Kukawa. He entered Bornu by way of Ngornu after leaving Logone and Kussuri in the charge of his lieu-

who was afterwards ruler of the Bahr-el-Ghazel Province under the Egyptian Government. Zubeir was succeeded by his son, Suleiman, who rebelled against Egypt in 1878 but was defeated and induced to submit. Rabeh, however, who had by this time become a chief, a rank he had won by his military services, refused to give in and escaped westward with a small band of armed men. After several years' fighting, he established his own kingdom at Dar Runga, between Wadai and Darfur. In 1891 he failed in an attack on Wadai and retired farther west. Then ycars of fighting followed in subduing kingdoms and making treaties till he eventually established his capital at Dikoa. It was in 1899 that Rabeh, who was a hater of the white man's rule, came in contact with the French Mission under Gentil, and defeated and annihilated a French force at the Togbau Hills. Later in the same year he met the French again at Kuno, which, though a drawn battle, shook his strength so severely that the heart was taken out of his resistance. But once back in Dikoa, he lost no time in making preparations for a great and final effort, and on April 22, 1900, gave battle to the French under Major Lamy near Kusseri. The battle was most hardly contested, but in the end Rabeh was defeated and killed. In the account which is given in my brother's book the fortunes and the fate of this splendid fighter are summed up in these words: "So died in greatness Rabeh, the slave boy who out of his genius for war had created a kingdom and carried it through a continent upon the points of his spears."

The French leader, Major Lamy, was also killed in the battle, and the account which Boyd gives makes the wounded Rabeh himself kill Major Lamy, in the same moment getting his own mortal wound, so that as the story goes, "the two great chiefs fell apart-dead." The French, however, say that this is not correct and that although both leaders were slain in the fight there was no connection in their deaths. Boyd was always greatly fascinated by the personality of Rabeh, and in his travels whenever opportunity occurred gathered details of the great fighter's history from native sources. Sereral of his own escort had fought under Rabeh in these very battles against the French, and they used to be drawn by José into telling their stories round the camp fire at night. In this way some interesting things concerning Rabeh, not known before to the white man, were brought to light and appear in the notes upon Rabeh which my brother gives in his book. However, as we have seen in the case above, these stories though 
tenant. His force consisted of ten flags, or something like 2,000 men, but it was weak in cavalry. Holding commands in his army were his two sons, Faderella and Mama N'yebbi, and also the famous Babirr, in whom Rabeh found a captain worthy of himself; but N'yebbi, a fiery youth, did not altogether gain the confidence of his father. It is told of him that he used to enter his father's mosque, with the object of making a disturbance while the Mallams were at prayer, until he was driven out and forbidden to enter any more. Then in defiance he went off and set up a rival mosque. On reaching Kukawa, Rabeh found it deserted, with the exception of a few Arab traders who came out to meet him. On his line of march this was what generally happened, but when the inhabitants of the village or town remained to welcome him, the place was always spared, while any soldier of his who was found looting or molesting the people was flogged, and a man guilty of an offence after his third flogging was shot.

But in cases where towns were deserted, or proved hostile on his approach, the soldiers were allowed to loot, but restrictions were always made in this respect; gown cloth, \&c., could be retained by the looters, but all slaves, horses, and cattle were brought in to Rabeh, who as a rule took half, the other half being divided among the soldiers. The night before Rabeh entered Kulawa, the Shehu, Ashimi, and his brother Kiari fled with all

picturesque are not always accurate. Curiously enough, very much the same idea occurs in the description of another chief's death, which Boyd gleaned also from native sources and gives in the present diary (p. 157). I have sometimes thought that the explanation might be that it is a picturesque convention of the native historian always to make a hero die killing an enemy. Certainly the colour of truth is lent to the story of Rabeh's death by the fact that the French commander was also killed in the battle.-ED. 
their followers in the direction of Geidam, where it appears they separated, Ashimi establishing his quarters at Mana, near the Gujiba-Geidam road, and Kiari at Gumsar, a day's march from Mana, where the latter rallied his followers with the intention not only of marching against Rabeh, but of usurping his brother's rights as Shehu of Bornu. Kiari was brave and a born soldier, and had won the hearts of his men, not only by his personal prowess, but also by his custom of giving largesse. Unfortunately for him, he was a victim to the ravages of a malignant disease, and seldom uncovered his face, his nose practically having been eaten away, and his speech was so much affected that there was only one person amongst his people, a Mallam, who could understand him.

Having decided upon his action, Kiari sent a messenger to Ashimi, telling him that he intended to become a Shehu, and at the same time asking him to join him against Rabeh. But Ashimi refused, saying that there could not be two kings of Bornu. Later Ashimi came in to see Kiari, who received him with so much royal pomp that Ashimi, reputed for his meanness, exclaimed: "What does all this mean? I have never been brought up in this way of living; my men will desert me." $\mathrm{He}$ thereupon refused to have anything to do with Kiari, and returned to Mana. Meanwhile Kiari was made to believe through slanderous reports that his brother was preparing to fight him, and this decided Kiari to have him killed. The murderers reached Mana in the early morning and found Ashimi sitting on his mat at prayer. He was inmediately shot.

His force thus augmented by Ashimi's followers, Kiari marched to Gashagar, and thence went out to meet Rabeh, who was advancing from Kukawa. At a place 
called Ladibida, five hours from Gashagar, the two forces met, and Kiari defeated Rabeh, who was obliged to retire into the bush. All his baggage, however, fell into the hands of Kiari, whose men at once started looting, and all discipline was thrown to the winds. Boxes were broken open, and Rabeh's treasures scattered on the ground. But, taking advantage of Kiari's demoralisation, Rabeh again returned to the attack and reversed the fortunes of the day and put his enemy to flight. In vain did Kiari try to save the day, and by his personal bravery won the admiration of Rabeh. In the fight he seemed to bear a charmed life, and no bullet would touch him. Then Rabeh commanded one of his men to shoot down Kiari's horse. This being done, Kiari was surrounded and captured. But, in admiration for his bravery, Rabeh offered to spare his life provided Kiari would serve under him; but the brave Kiari refused all his offers, saying that he was no slave. He was then put on a horse and led into Gashagar, where again Rabeh tried to persuade him; but it was of no avail, so Rabeh commanded his executioners to kill him, his throat being first cut and then the head severed from the body. Afterwards the head was put in a box with salt and sent into Dikoa, and the body was thrown into the river.

It was Rabeh's policy to spare every one's life provided he agreed to follow him. This is how he increased his army when on the march. Those agreeing to fight for him were told off to the various "flags," and, did they prove themselves capable, were given guns after the fifth or sixth day, each man receiving seven dollars a month.

After the destruction of Kiari's force Rabeh made a tour through Bornu by Geidam, Gumsar, and Marte, but he received no further opposition. He then established his headquarters at Dikoa, where we find him 
making preparations to found a vast kingdom stretching from Kano and Damerghrum on the west to Wadai on the east. His reign over Bornu lasted seven years.

Rabeh's order of march was as follows: First came an advance guard of horsemen; next the women and boys and baggage; then Rabeh himself and his staff; and finally a rear guard of mounted men and infantry, and then there were infantry supports on either wing.

He always kept himself in a central position, so as to be able to render assistance at any threatened point. If he was attacked either on the right or left flank, he would at once move up to the threatened point, the rear guard at the same time moving up to protect the women and baggage.

His method of attacking a village or town marks his qualities as a soldier. A general enveloping movement would be made with both flanks doubled forward, whose duties were to cut off retreat should success attend the attack, which was always directed against the centre of a town by a force directly behind the advancing line.

Should he arrive before a town too late to deliver an assault the same day, he had high platforms erected on which he stationed sentries to overlook the exits of the town.

October 15.- There was the first harmattan to-day. Whether this is altogether due to minute particles of sand blown from the desert is, I think, open to doubt. Certainly there are many days with the north wind prevailing when the atmosphere is perfectly clear. On the other hand, in December, when the grass fires are burning, the atmosphere becomes very thick, and one gets the typical aspect of the "harmattan," when the branches of the trees are coated with a dust-like layer, much like hoar-frost to look at. This may be sand, but 
I think it is more likely to be fine ash, although we cannot altogether disregard the presence of sand, for we know how in places in the desert the surface has been formed into billowing sand dunes by the wind. Brocklebank holds to the ash theory, and he says he can make a "harmattan" to order (and has done so) by burning grass the day before, the whole air becoming thick with fine ash the next day.

October 17.--Yelua, the present town of the Shehu, and situated half-way on the road between Maifoni and Maidugari, is a rambling and poor place after Kukawa. The streets are badly laid out, while the palace and the houses of the "big men" cannot hold a candle to those at Kukawa, where the "big men's" houses line the sides of a wide approach from the market to the square building of the palace itself, a distance of quite half a mile. But Kukawa is a mass of ruins now, and grass grows in the streets, and the tombs of the former Shehus lie unprotected. O Kukawa, how is thy glory departed!

I have been more than once to the Maidugari market. It is now, since Kukawa has been abandoned, much larger than it was when I was last here in 1904. The market has just now been fenced in, and the system of gate-money (one-tenth of a penny) instituted. This is excellent, as it does away with the extortions of the Serekin Kasua, * who, although he had only the right to charge 5 per cent. on all transactions, it was well known levied pretty well what he liked. Now all this is done away with and he receives a fixed sum every month out of the gate-money. The market has also

* A Serekin Kasua, or king of the market, is appointed to each market as umpire in all disputes arising between buyers and sellers. He also fixes the prevailing prices for the day.-ED. 
grown in extent. Sellers, fearing no more extortions, bring more things than they used to. A stall-holder pays fourpence per month.

Went to the Salla. This is the Mahommedan Christmas, lasting for three days. It is made the occasion for the Kachellas and their people to come in to the Shehu, who generally gives presents to them and the headmen.

A large tent, very much like that of a travelling circus, had been erected outside Yelua, and here at eight o'clock came the Shehu with his retinue to offer up a thanksgiving. Before his arrival Kachellas were coming in from all parts with their horseman and bands, the horses richly caparisoned and hung with coats. The clear blue sky and the brightly shining sun brought out the medley of colours to perfection. Prayers from the Koran were said by the Head Mallam inside the tent, while on a large cleared space outside stood many Mallams and devout worshippers, the majority in turbans and clothes of white. Facing the east, row on row they stood upright and listened to the prayer that came from the Mallam within, and as the words, "Allah hak a buk" rang out, which told of its ending, all with one accord prostrated themselves on the ground and the whole congregation became a sea of bended backs. And so it was repeated after each prayer. During the fasting, which lasts for a month, they do not drink between sunrise and sunset, and strict Mahommedans live apart from their wives.

October 20.-At last we are ready for a move from Maifoni, and I have decided to stay for a short time at Konduga, where the Kachella, Kakami,* lives. I

* Much is told of this chief in "From the Niger to the Nile." Kakami was at that time (1904) Kachella of Yo, a post he held under 


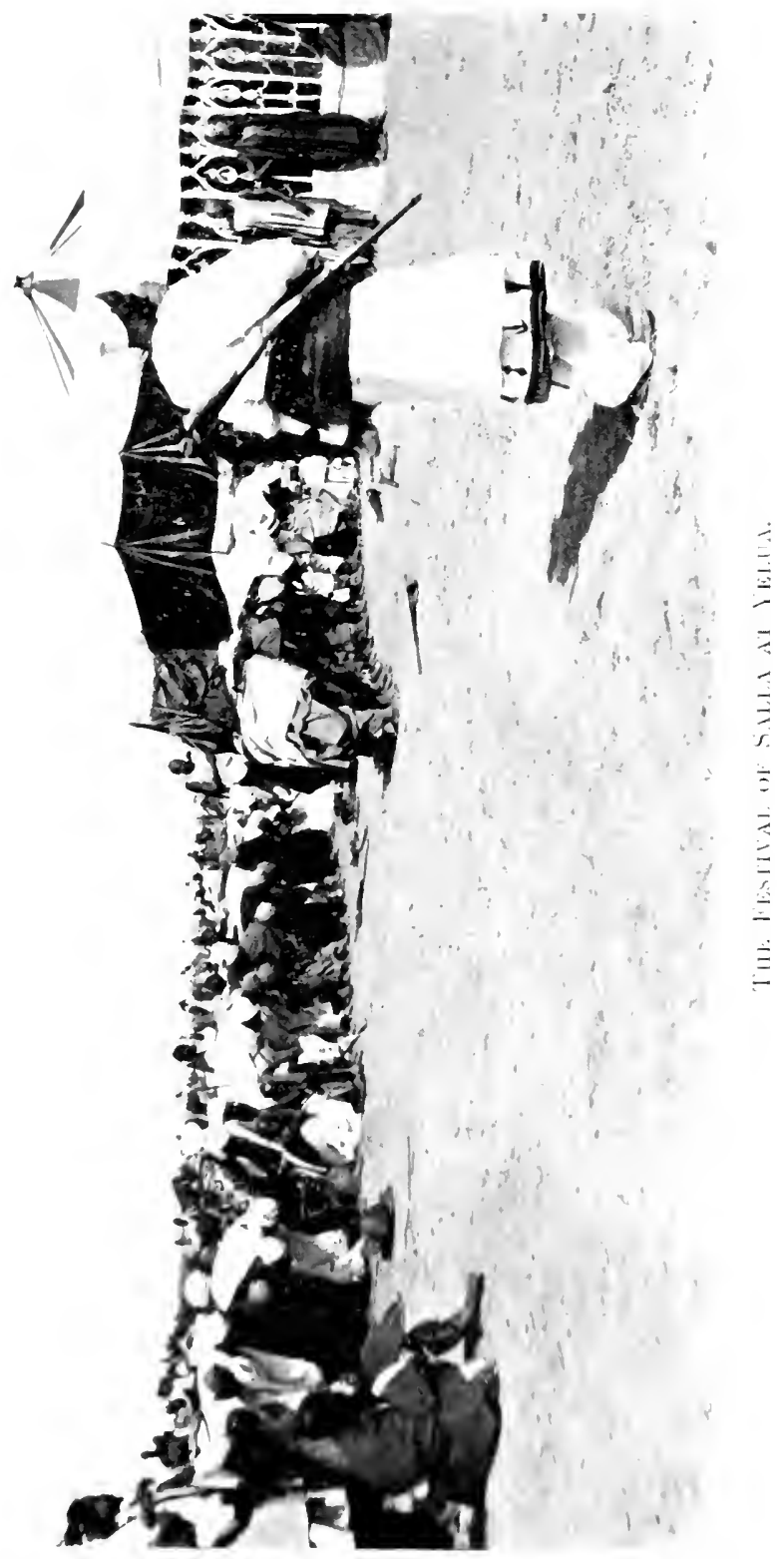



hear that it is a good place for camels. This will be all on my way, as it is on the road to Dikoa.

We stayed the night at Waluri, about two and a half hours from Maifoni. I am making a route sketch(prismatic and pacing). On the way to Waluri, a vast expanse of flat country, nearly all cultivated, stretches away to the horizon, dotted here and there with thick-leaved trees growing singly or in belts. The crops of "gero" have been gathered, and there still remains the guinea-corn which has grown up sparsely amongst the former crop.

October 21.-A three hours' march brought us to Konduga, and we took up our quarters in the resthouse. Konduga is a fairly large town, all Bere-Bere, and it has once been walled. Cloth-dyeing is carried on a good deal, and there is a large market. In the evening José and I went round the town, and were greeted by many old friends whom we knew at Yo when the Kachella was there.

October 24.-Bad attack of fever, with ague and vomiting.

October 25.-Convalescent. The Kachella, who has been away at Yelua, came in to-day, and hearing that I had been ill came up at once to see me. $\mathrm{He}$ is a black gentleman, and likes the white man. This resthouse is unbearable; a marsh close by provides it with plenty of mosquitoes, who rest not day nor night. I shall move to-morrow, the Kachella having promised to make

the Shehu as a man strong enough to stand up to the Tubu robbers who were for ever raiding across the border. Boyd describes him as by far the bravest and noblest chief he had met with in Africa. In his book he gives an account of the exciting time when he went to the relief of Kakami and a Mecca caravan, who were besieged in Bulturi.-ED. 
me a camp with zana matting outside the north end of the town.

November 1.-Left for Maifoni to settle up things finally, chiefly to get $£ 50$ from Brocklebank, to whom $I$ had given a cheque.

November 3.-Two men were hanged in Maidugari market to-day. The Shehu's court is now allowed to condemn to death, this being the third instance. The culprits were notorious highway robbers, the like of whom are numerous in Bornu, especially among the Shuas, who freely use the knife. The condemned left the native prison at Yelua to tramp the long, dusty road to Maidugari market, where they were to meet their fate. 'The escort consisted of a posse of the Shehu's soldiers armed and dressed in the Rabeh uniform. The whole party was in charge of the Adjir of Maifoni, accompanied by mounted men and the executioner, a man with a giant's presence. It was getting near midday and the market had assumed its busiest aspect, the stalls were packed, and every one, both buyers and sellers, were making the most of the only market day in the week. Hardly any one noticed the cavalcade as it passed through the gate and swung to the right, till the drummers of the party struck up announcing its arrival. The drums only ceased when the first corner of the market was reached. Here in the immediate vicinity silence fell upon the market, and the condemned men, with hands pinioned behind their backs and ropes round their necks, were made each in turn to step forward and speak out the offence they had committed, for which they were now going to their death. Then the party closed up and marched on, the drums of death sounding loud and strong the while. The second, third, 
and fourth corners were reached, where the same acts were performed, and then they marched to the gallowstree, a hundred yards away from the rows of stalls and where the space was not occupied except by strings of tethered oxen and horses. The gallows consisted of a rough tree-trunk planted in the ground, with a knotty limb going off almost at right angles and about six feet above the ground. This served as the cross-bar from which the murderers were to hang. Quickly the party closed round it, while the drums beat louder than ever, causing a hush to fall upon the market. The people in the stalls did not move, but idlers and those who had come with market errands pressed forward to the place of execution till it became like a sea of black heads. Very quickly three stalwart soldiers surrounded each culprit, lifting him bodily up till the loop of the noose round his neck was within grasp of a man who had climbed to the cross-piece. The latter immediately slipped the loops round two of the knotty stumps of the limb. A moment elapsed, no more, and the bodies were let drop with a jerk. Then the sufferings of the condemned commenced, for death in this way comes by strangulation. All through the heat of the day till sundown the bodies hung there stark and motionless. The hum of the market continued, things were bought and sold, and no one seemed to care or think that Death had stalked that day through their very midst.

I left the same afternoon for Konduga and arrived the next morning. At the place I stopped for the night I found my cook had not turned up, though he had orders to do so. So I had to make the best of it, my supper consisting of "gari." * -ED.

* "Gari" is corn ground for food. As a crop it is called "gero." 
November 4.-Konduga. I have been struck with the number of blind here, especially among the women. I have asked several, but none can attribute their blindness to anything, only saying that it has gradually come on. I looked at more than one, who though not yet blind would become so in a few years. The disease is insidious, beginning usually with a cloudy white spot on the cornea below the pupil; this gradually spreads like a thick film over the whole eye and blindness results. I think it must be due to the dust and particles of manure straw which are blown about by the north-east wind at a certain time of the year. The dirty condition of the villages, and the heaps of rubbish and dry dung which surround them, when disturbed by strong winds, must be most injurious to the eyes, and it is a significant thing that there are many more cases of blindness among the women, and I attribute this fact to their always having to do the sweeping in the houses, \&c.

November 5.-I am busy adding to the number of my horses, and I hope to leave here with six or more. I am paying for them, on an average, $£ 4$ to $£ 5$ each. I hear that horses in Abechir are wanted badly; the price being $£ 25$ to $£ 30$, or six camels for one horse. If this be the case, and I get to Wadai, I shall be able to make a bit ! The Kachella has lately been coming to see me, generally towards evening. We sit down and chat over a cup of coffee. This morning Garuba (of all people) was nowhere to be found. This is the man I found at Baminda in the Cameroons. He had gone up to Kano with José to get the camels, and was receiving the high pay of $£ 2$ a month. At the time of his disappearance he had more than $£ 4$ for his book! It is quite inexplicable, unless it is a case of "funks." I hear he met a man in Maifoni, just come through Wadai, who enlarged upon the dangers of the 

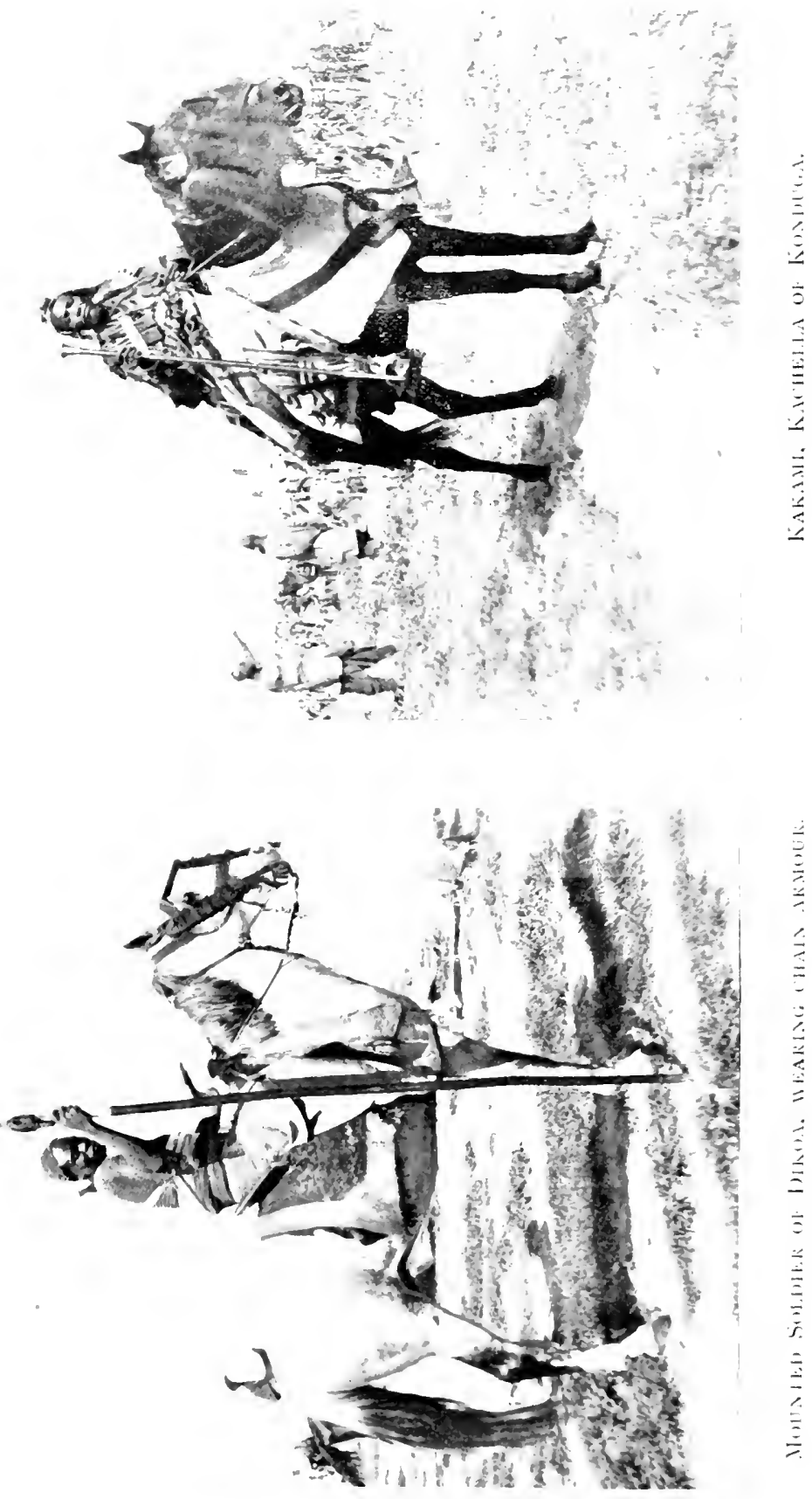

\begin{tabular}{l}
\hline \\
\hline
\end{tabular} 

road to him. For an expedition of this kind the Kanuri is a worthless creature : he has no pluck to face any difficulty. With him I would rank the Fulani and Jukun. The only people one can rely on, who do not mind leaving their homes, are the Hausa, Baghirmi, and Yoruba; that is my experience.

November 11.-Left Konduga for Marte. The column consists of six horses, five camels, and ten boys. We got on the way somewhat late (eight o'clock), but this is generally the case the first day of a trek, when I always allow a short march before getting into the even stride. We stayed for a night at a small Kanuri village called Arnari.

November 12.-Harmattan blew early this morning, and sun rose as a red orb. Reached Miktari, a Shua town. All these Shua towns are filthy, and the cattle live in the houses. There are not many of the paleskinned people to be found now, for they have intermarried very much with the Kanuri. By the by, the Shuas first settled in this country when Laminu came over. He brought with him three Shuas, who finding it to be a land of plenty went back and brought others.

November 13.-Gubduri (Shua). While here a man brought me his little son (about six years old) for treatment. He had for the last few days a stoppage of the bladder, and was in great distress. With José's help I managed to pass an instrument, but, unfortunately, though I made several attempts, I failed to produce a proper flow. The child was deformed from birth and could not walk, so I fancy he must have had a malformation. He had suffered in the same way before.

November 14.-I stayed to try and give a little more 
relief to the sick child, but was not more successful than yesterday.

November 15.-Arrived at Abari (Kanuri). José shot a Senegal hartebeest here. This is most welcome.

November 16.-Stayed Abari, being " off colour."

November 17.-Marfa. On the way José shot a gazelle (Berrewa, Hausa). This is about the only game to be found in these parts.

November 18.-Mina.

November 19.-Marte. Arrived here on the market day, which is a big one. Kunuri, Shua, and Mandara were the chief peoples.

Marte is a big town, with mud buildings; but these suffered at the hands of Rabeh, who passed through here on his way to Dikoa. The inhabitants number about one thousand, and are all Kanuri.

All the men had an advance of five shillings to-day. Until I gave the order they found it extremely hard to get the threepenny bit accepted in the market. It does seem extraordinary that only two days from Maifoni, and after so many years in use, this coin is distrusted. I am afraid the dollar will die hard; personally, I should encourage its circulation, and make it the trade coin between the three nations. Under the present conditions there are four coins in circulation-the dollar, and the English, French, and German coins. When passing from one country to another this must entail annoyance, and a certain amount of check to trade also.

As I do not think that I have a sufficient number of dollars, and far too many threepenny bits, José leaves this afternoon for Maifoni to change the latter into dollars.*

* The dollar in Bornu has the fixed value of 2s. 6d.-Author. 
November 20.-The second boy (a Bere-Bere) bolted during the night. This bears out what I have already said about the Kanuri. "Misfortunes come not singly," \&c., and the camp is roaring with sickness, and one of the camels has cancelled its captivity. Under all these difficulties, and being all by myself, I do not feel the peace of mind which I should like to have. But I must hope for smoother days.

November 24.-José returned all well, bringing with him another camel-boy, this time a Hausa. A telegram from O. M., saying "Best wishes."

November 26.-Market day. I have bought another pony for $£ 4$. It is small, but a very fast goer. This brings the number up to seven.

About here, and in many places along the road from Konduga, there are vast fields of "Mussowa" or "Mussakoa" (Hausa). It grows to a height of about four feet, and both the stem and blades are very much like those of the Indian corn, but it has a flower like that of the guinea-corn. It can only be grown on a clay soil, which holds water during the rains. The growth seems to be confined to the eastern portion of Bormu, and is gathered at the end of December. The stem is chewed, after the manner of sugar-cane, by the natives. It has much the same properties as sugar, but the percentage is not so large.

November 27.-Left Marte and arrived Ala, distance twelve miles, a large Kanuri town with a fair-sized market.

I generally make my camp under a fig-tree in the town I stop at. It gives good shade, and to make it more private I have zana matting put up all round the tree, at a certain distance from it. The only disadvantage is 
that snakes now and again drop from the tree, but finding themselves cut off are obliged to face the zana matting, and this gives one an opportunity of killing them. On the cry "Machiji" (Hausa, snake), my compound is filled with boys armed with sticks, all shouting, and trying to deal death-blows at the reptile as it glides up the matting.

But the snake is not the only visitor, for a thud on the ground tells one that a bright chameleon has fallen from some leafy bough. The species here is a very bright grass-green, and it affords a most interesting example of protective coloration. I have watched one of these brilliantly coloured chameleons walking over the brown earth without attempting to bring itself into harmony with the colour of the ground, and it is then a most conspicuous object; but so soon as it becomes aware of the approach of danger it immediately turns a dusty brown, and is then hardly distinguishable from the ground. Seeing this, one is almost inclined to believe that the chameleon has developed a more highly organised power of protective colouring than has any other animal, and almost more than can be called mere "race-consciousness."

Besides the snakes there are more welcome guests to my tree, and they are guinea-pigeons (Guiniensis). They come towards evening to claim a night's rest, and often the hot sun at midday will send them to take shelter under the shady leaves. These birds are numerous about here, and frequent the roofs of the native huts like tame pigeons. They are plump and good to eat.

December 2.-Left for Dikoa, distance twelve miles. Up to the German frontier, which is marked by a telegraph pole, the road passes through vast fields of "Mussowa" that extend as far as the eye can reach.

As soon as the frontier is passed one cannot help being struck with the poverty of the ground and the dearth of 
villages, as compared with Bornu. From the frontier a march of five miles brings one into Dikoa, a splendidly situated town since, for a considerable distance, the ground rises gently up to it.

The market is first reached, and then a broad street, with mud buildings on either side, leads into a large square, formed on the east side by the great fort built by Rabeh, and on the west by the palace of Faderella and the mosque; while behind these buildings, again, is the palace of the Shehu, the walls of which can just be seen from the square. The fort is a fine one; the front wall has a length of something like two hundred yards, and the depth of the fort is two hundred and thirty yards, the walls running to a height of fifteen feet. Inside there are many substantial buildings, and the one which Rabeh lived in is now occupied by the Resident. During Rabeh's time there were many more buildings, the dwelling-rooms being reckoned by the hundred. The amount of labour expended on the palace must have been prodigious. To any one familiar with the history of Rabeh, this place is deeply interesting, for it is here that the black Napoleon has indelibly left his mark in the great fort itself, Faderella's palace, Béhagle's monument, the lime garden, and the Rabeh uniform still worn by the soldiers of the present Shehu, Sanda. It is difficult to realise that Rabeh met his death only such a few years ago as 1900. The romance that his exploits have woven round his name places him in the imagination rather as a figure of the Middle Ages than of to-day. The great changes that a few years have brought about in Africa have a good deal to do with this, for under the present conditions of the New Africa a man like Rabeh could not exist.

The market, which is held every day, is a fairly large one, 
but not so big as Maidugari. Kanuri and Shua are the chief elements of its people. There are also quite a number of Tripoli traders coming from Kano and Maidugari and through Kukawa from the Saharan-Tripoli route. Sanda, the Shehu, is a good buyer of Tripoli goods. Within the confines of the market is the tomb of Béhagle, the Frenchman who was hanged by Rabeh. The monument is in the form of an obelisk and is made of mud. Béhagle was a French trader, and the first man to ascend the Bamingui. He did not get, however, very far up this river, his boat being smashed at the rapids about four miles above its confluence with the Shari. We also encountered the same rapids in my expedition of 1905, but passed them successfully. Béhagle then returned, and in company with another trader made his way down the Shari. His friend realised that discretion is sometimes the better part of valour and turned back, but only just in time, for not long afterwards Béhagle was captured by Rabeh and thrown into prison at Dikoa. It was after the battle of Kuno that Rabeh realised that he had found his match in the French, for at this engagement, although it was a drawn one, he lost many men. Then followed what was, perhaps, the one blot in the history of this great man. Out of revenge or anger he sent a messenger to Dikoa with orders that Béhagle was to be hanged at once. For five months the latter had been a close captive in chains. He was not told of his fate even on the morning when they marched him from his prison-house to the market square, where at midday he was hanged. The words he uttered before he met his doom were prophetic: "You may kill me now, but Rabeh will never sit down in Bornu." The sight must have been a horrible one. The gallows, rude and ill-constructed, simply a bar resting on two forked 


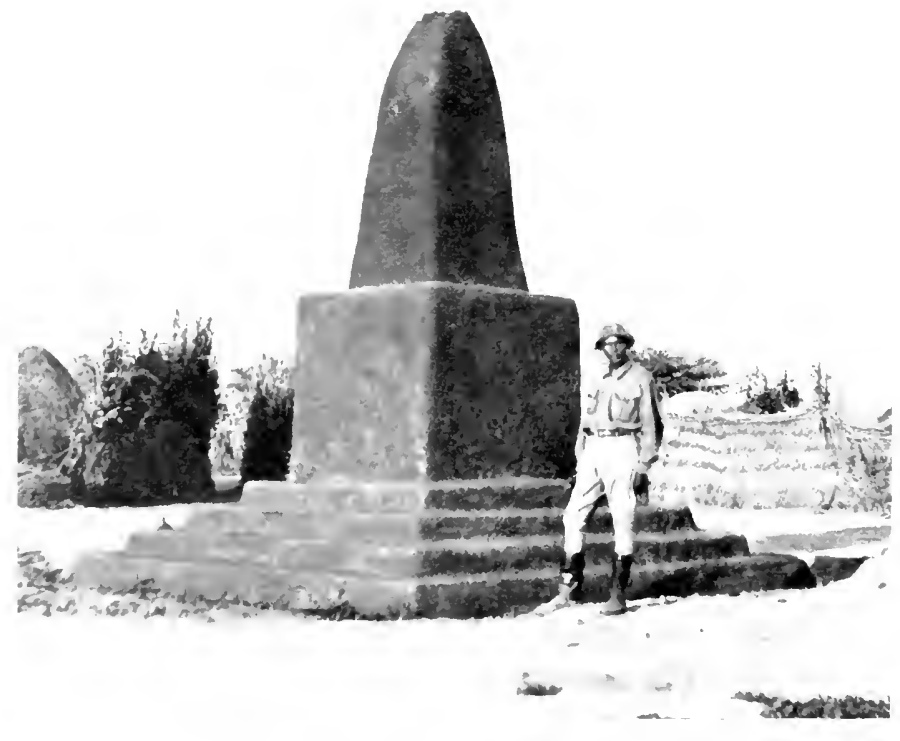

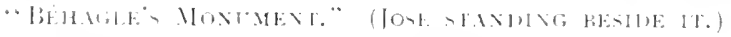

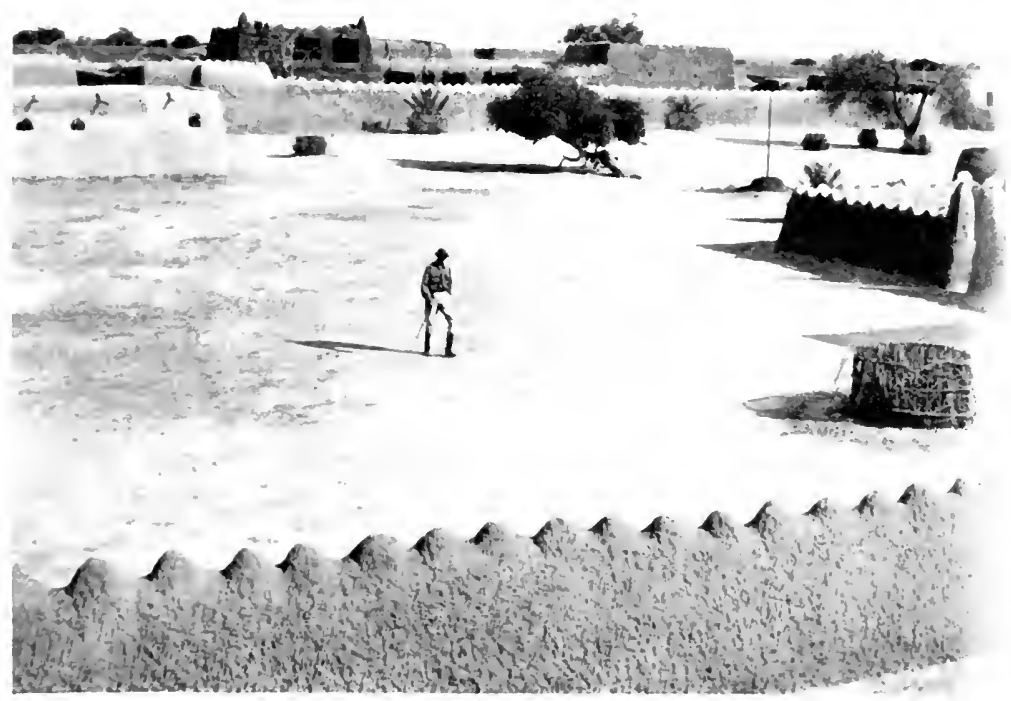

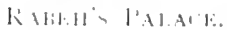



poles, could not have brought a quick death, while people from far and near flocked to see the white man die, thronging the market square in hundreds. His body was left hanging until sunset. These events happened in October, 1899.*

Dikoa is fortunate in having a lime garden, for limes are seldom to be obtained in Bornu. A peculiar interest is attached to this garden, for it was planted by Rabeh. The two original plants came from Maidugari and Kano. Besides the case of Béhagle, Dikoa was also the scene of a conflict between Faderella and Hiatu. $\dagger$

Hiatu, the son of the Sultan of Sokoto, was the king of Bulda, a large Kanuri and Fulani town about four days from Dikoa. On hearing that Rabeh had reached the Shari, Hiatu, realising the power of Rabeh, decided to join with him, and with twelve flags met Rabeh at Mundjaffa on the Shari. He was received well and became one of Rabeh's chief lieutenants, and the bond was further sealed by Rabeh's giving his daughter Howa to him in marriage. Then, strengthened by this further addition to his army, Rabeh, in conjunction with Hiatu, decided to invade Bornu, making Kukawa his objective, as soon as the necessary supplies of corn could be got together.

The events of his Bornu campaign up to his entry into Dikoa I have already related. Rabeh now entered Dikoa without opposition and made it his headquarters, surrounding himself with all his great captains and lieutenants. After staying in Dikoa for a month, Rabeh set out to attack Mandara, which he subdued, bringing away with

* From Kusseri Béhagle left for Dikoa with a few followers, determined to throw himself on the elemency of Rabeh, but this foolhardy coup did not come off.-Author.

† From native information.-Author. 
him as prisoner the king of Mandara himself. No sooner did he return, than news reached him of the advance of the French under Gentil down the Shari, and ever a fighter he set out to meet the new eventuality and to cross swords for the first time with the white man. During his absence Faderella was placed in command at Dikoa, with Hiatu as his lieutenant. It was during this time that Hiatu began to cool in his allegiance to Rabeh, and he determined to break away and return with all his followers to Sokoto. The night before he prepared to leave the town without the knowledge of Faderella, he made his wife Howa a prisoner, with the intention of killing her before he left, so that he might make doubly sure of his departure being kept secret, anyway until he could have stolen a march on Faderella, who, he felt certain, would follow him. Unfortunately for him, Howa with the help of two slaves made good her escape and immediately informed her brother Faderella of Hiatu's intentions. Although the latter had already started Faderella came up with him on the open ground to the south of Dikoa. In the first encounter Faderella sustained a loss of twelve men, and Hiatu, encouraged by this success, rode back with sword unsheathed to fight his foe in person, but all to no purpose, for the next minute he fell riddled with bullets from Faderella's revolver. His fall was the signal for a hundred of his faithful Fulani followers to close round his body, who, refusing to leave it, were shot down to a man. The same fate overtook the remainder of his force, who were followed up and killed.

December 4.-The German occupation of this portion of the Cameroons might be described as a passive administration. There is only one man here (Lieutenant von Duisburg) who acts as Resident, but everything is dealt 
with by the native court under the Shehu. At present the Shehu pays the Government a yearly tax of 7,000 marks, and a certain quantity of grain besides. Dikoa numbers about 8,000 people, and the Shehu is said to be able to muster 1,000 foot-soldier's and 1,000 horse. Anyway he is to all appearances much more powerful than his brother, Garuba, the Shehu of Bornu, and I should say a man of much stronger will than his brother, who allows himself to be influenced to his detriment. Yesterday, Sanda gave a review of all his troops, following a demonstration outside the town by the Resident of the powers of the machine gun. Altogether 1,000 cartridges were fired in less than three minutes, and the scene was intently watched by the Shehu and his soldiers and hundreds of his people with wonder and awe. The name given to the gun by the Hausas is "Mirrau," meaning a water-gun.

Half an hour later the great square in front of the fort began to hum with life; people crossed and recrossed till the sides nearest the walls and buildings were thronged. At the far end of the square looking from the fort, the three exits-the one on the right leading to the market, that on the left into the quarters of the Shehu's soldiers, and the one in the centre into the palace itself-allowed just the necessary exits and entrances to those taking part in the review. Then followed a display of barbaric splendour which would have stirred even the most jaded sightseer. "Flag" after "flag" and rows of horsemen, each headed by a royal Prince (Abba) or a Kachella, swept over the square to the accompaniment of kettledrums and alligatas, the men in straight jacket-like gowns, gorgeously striped with colours according to the fancy of the wearer, and wrapped round the waist with bands of cloth over which ammunition-belts were worn; 
and the horses heavily caparisoned with arrow-proof coats, and the heads of the long spears carried by the men glinted and flashed in the sunlight-all showed out in bright relief against the white walls and the sandy ground that glared in strong contrast to the blue sky overhead. As they advanced towards the entrance of the fort, where the Resident was waiting on horseback to receive their salute, the pace quickened into a charge, and the next moment the horses were suddenly drawn up to a dead stop within their length. Then a great shout of homage was raised, and spears were shook and held in the air. The last "flag" had come and gone and taken up its position at the far end of the square. Then in the distance where the road leads to the market comes the roll of many drums and the sound of alligatas to the accompaniment of deep blares on the long brass trumpets. Nearer they come, and then the great umbrella which shades the royal head can just be seen over-topping the mud walls. The king is coming ! The next minute the great "flag" emerges into the square and spreads out into line, a living ribbon of gorgeous colours. The king is in the centre, and on either hand are his bodyguard, distinguished from the rest by their mitre-like helmets surmounted by ostrich plumes and ornamented round their sides with small round mirrors that flash bravely in the sun. Half-way across the square the music swells even louder as it mingles with the cries of adulation from the populace; horses prance and the great line sweeps on, to be met by the Resident, who joins with the Sultan only to halt and turn about at the foot of the fort, over which the German flag is flying. Then, amid the roars and cries of the people and the beat of drums and the gruff notes of the trumpets, the "flags" again come on to salute the king as they did the white man. When all have passed they troop out in 


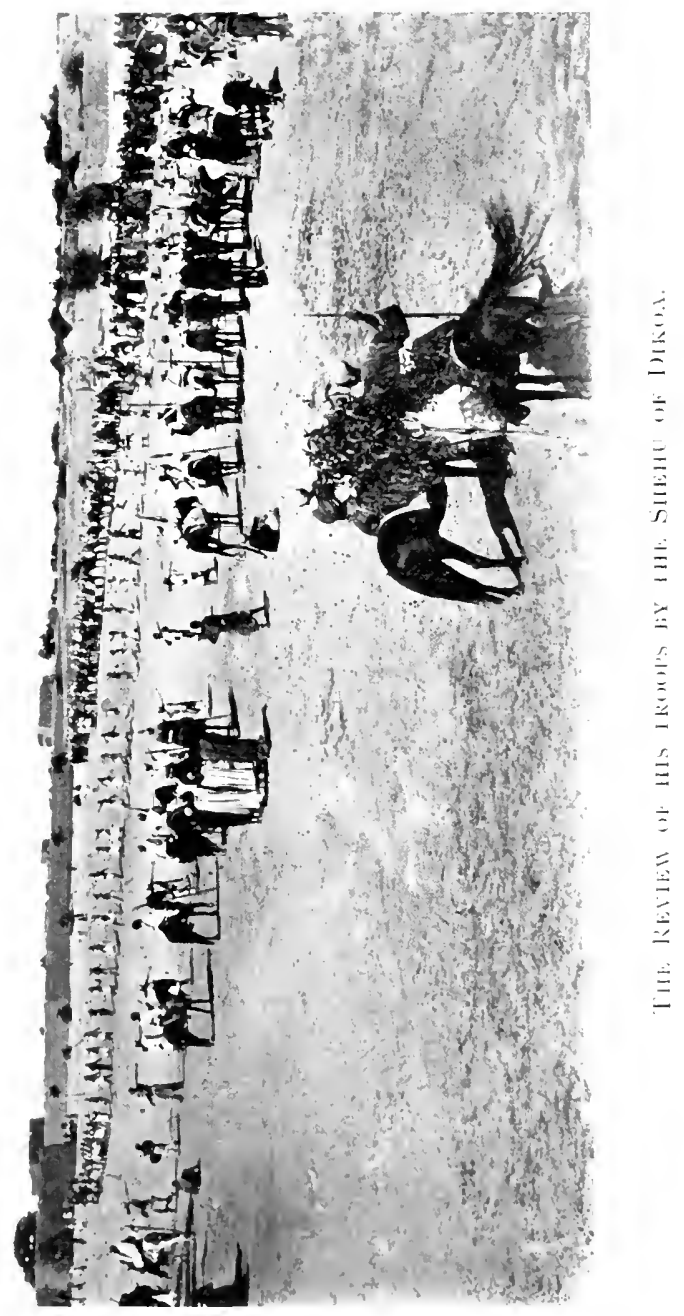



single file from one of the entrances at the farthest end of the square. The foot-soldiers are all armed and wear the Rabeh cap and uniform, and as each man passes the king he raises his rifle from the trail to the short-arm. All are proud of spirit as they render homage to their king. Again the music changes and the drums beat out in rhythmic time, to which the bodyguard responds by swaying to and fro with a dancing motion in their saddles. The review is over, but before the Sultan turns to go shrill cries of acclamation go up to him from a crowd of women who have sat in the market square through the heat of the days, toiling hard and late to support the soldiers of their king.

The Resident here has received me very well, and has made my stay here most pleasant. He speaks English very well. In the afternoon, about four o'clock, we paid a visit to the Shehu, having previously warned him of our coming. At the door of the palace there were several of his guards to receive us. After passing through the entrance we found ourselves threading our way through a dark passage, then across a small courtyard, then through more passages and several rooms, finally emerging into another courtyard, at the farthest end of which stood the Shehu in front of the entrance to his room, waiting to receive us. As we approached him and shook hands a kind smile lit up his face. We then entered his room and sat down on chairs made ready for us. In appearance he does not look more than forty years of age, although I belicve forty-three is the correct number, so he is considerably younger than his brother, Garuba. Besides a rough moustache, both his face and chin are bearded. His features are somewhat heavy, and the nose, though straight, is rather thick; but these characteristics are not so noticeable, since he is stoutly 
built and nearly six feet in height. His charm lies in his kind look, and in the ready way in which he arouses one's interest in him by the wish he shows of gaining information of things outside his own world, a rare trait in the character of a black man. His open countenance is borne out by his reputation, for he is known as a man full of the milk of human kindness, and is continually making presents. Every day he feeds in his palace 120 of his people, and on big festivals this number is increased to 600 . As soon as we had sat down he began asking us many questions as to the white man's country, how big the steamers were, and when I told him there were some which could take more than a thousand people he opened his mouth and eyes in amazement and clapped his hands softly together. Then he looked at my rings, remarking that no two white men wore the same kind, and then he asked how much money could be spent on one ring. Anything up to and beyond a thousand pounds again made him stare. I tried to make him realise the worth of the Cullinan Diamond, but I could not convey to him the amount in his language. He asked also if it always rained with us, and what times we gathered our crops. Then I explained to him that in winter the rain often turned to snow and the water became very strong, so strong that a man on horseback could ride over a river. At this he raised his hands and exclaimed "Allah is great."

I think he wanted us to sit with him for another hour, but the light was going, and as I wanted to take his photograph the Resident expressed to him my wish, and we all left the room, going out into another courtyard, where he posed for his picture. His dress was a richly embroidered burnous, over which he wore a flowing gown of silk, evidently from Tripoli, and a pale rose in colour. 
Like all "big men" in this country, he loves to display his wealth and importance in the number of horses he keeps, and so, responding to his wish, we followed him beyond the dwelling-houses of the palace to an enclosed space behind one corner of the big wall that surrounds the palace. On the way women drawing water at the wells within the enclosure hid their faces as he swept by. This is the custom, and only the actual wives of the Sultan are privileged to look on him within his grounds.

The horses, some twenty or thirty in number, were all big ones, and much too fat to cover the ground quickly, but the native loves a high and well-filled-out horse. These particular ones are artificially fed with specially prepared balls of "gari," much in the way we stuff geese. In this country there appear to be at least three distinct types of horses. First of all, there is the Tubu pony, in height not more than eleven to twelve hands, and a fast goer. The Tubu prefers a small pony, since, when making their raids, they are able to thread their way through the close mimosa woods much more easily and quickly than on a big horse.

The second type is the Bornu, one running from fourteen to fifteen hands. It is, I consider, the most useful of the three, for besides being a quick walker it has pace. The third is the largest of the three, and is bred about Dikoa, in Mandara, and the Logone country. The height is from sixteen to seventeen hands. Apart from its size, it can easily be recognised by its length of back. It has little pace; in fact, it is a carthorse as compared with the Bornu type.

After leaving the palace we rode to another part of the town, the Faubourg St. Germain of Dikoa, where all the princes and princesses and relations of the Shehu live. We went to pay a visit to the old Queen Mother. 
She had expected our coming, and in spite of her great age (eighty-five years) she had arrayed herself in her best to receive us. As soon as we arrived in the courtyard of her quarters she was helped out by an attendant and sat down on a mat in front of us. She was very tottery, and her face looked like a dried-up quince and her eyes were almost sightless. But yet she showed great pleasure that the two white men had come to see her. By her side sat the infant daughter of the Shehu, a clean-made and goodlooking child, with large wistful eyes. It was a pretty picture of youth and age. The old lady was the first wife of the father of the present Shehu. She is a Kukawa woman, and her husband was a Kanembu. Her name is Yamara, and the child's Yaashi.

The marks on the face of a royal child are two cuts on each cheek-thus ( ( - and two on each temple close to the ear.

The name given to all royal male children is Abba, and Nana to the female children.

December 5.-San Thomé is not at all well, has no appetite, and has become very thin; besides, he has a hollow stomach cough. He was in much the same condition coming up from Yola to Maifoni, but recovered a few days after reaching Maifoni. I fear it will turn out to be the fly-sickness. He has never been the same dog since he left the highlands of the Cameroons. Having been bred at the high altitude of 6,000 feet, he feels the heat and strong glare of the lowlands.

Left Dikoa, the Resident coming with me for some distance. The road goes away from the direction of Kussuri altogether, and takes a northerly direction as far as Ngala. This is to avoid the direct road, which is impassable owing to water. Two and a half hours brought us to Gajiro, where we stopped. A short march, 


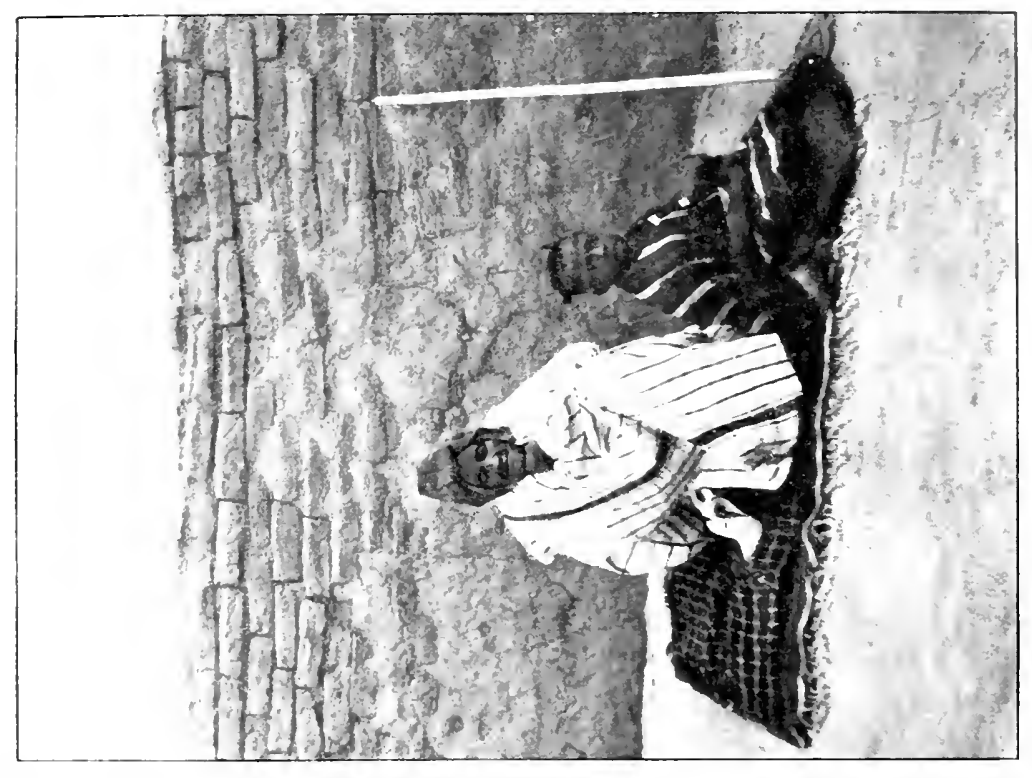

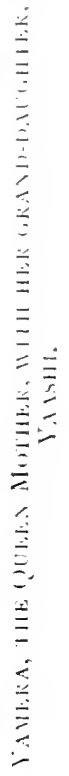

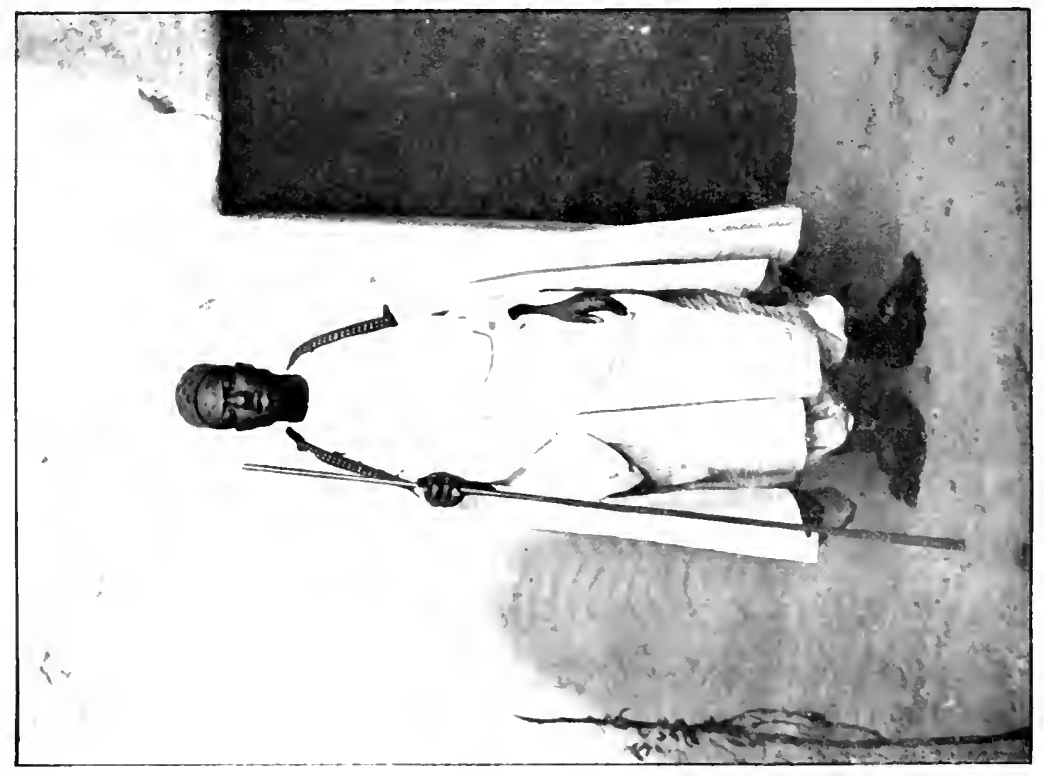

3
$=$
3
3
3 

but being the first of a new trek I think it is allowable. Gajiro is a large village, but there are many ruins, which give a dilapidated appearance to the place.

Towards evening the air swarmed with swifts ( $C$. affinis?). It is now the breeding season, the nests being made on the rafters of the mud buildings. I observed these vast congregations also at Dikoa, both morning and evening.

December 6.-From Gajiro we left the main road and took a long detour to the north to reach Logomani. This was on account of the water on the big road. Distance, nine miles. On the way thither José shot a gazelle (Barao, Hausa). Here and about this part a great deal of rice grows wild, and is gathered by the natives. It makes excellent porridge when it is ground. I have it every morning. Really, when one comes to think of it, one can do with hardly any stores in this country; tea, coffee, sugar, salt, and jam are all that are necessary.

To take my own case, for example, these are my meals. The first thing in the morning, before I get up, I have a cup of coffee or tea; then for breakfast porridge made of rice or alkama (and failing these, of "gari)," and eggs, either fried or as an omelette; then for luncheon I have soup made either of meat or ground nut, followed by meat or fowl. One can always at any fair-sized town obtain meat in the market, while very often, when trekking, one can get game. My supper consists of soup, brain fritter (if game has been killed), fried kidney or liver, cutlets, mince or roast, and custard pudding to finish up with when there are eggs and milk. The only thing one feels the want of is green vegetables, and these are not to be found in this part of Africa. In place of flour one can make cookies or flat cakes of alkama or ground rice 
mixed with "gari." Mussowa also makes excellent cookies. To look at before it is ground it is the same colour as Indian corn, but the grain is about half the size. I grant that to any one living in a station weeks and months together this menu would be dull in the extreme, but for me, trekking as I do, and seldom in one place two days together, I look forward to these meals with a certain amount of interest. There is a rough charm about them, and I feel I could hardly lead a more simple life.

A good deal of activity is shown here in cotton-spinning and weaving. Of course the spinning and looming is primitive, the width of seam turned out by the native not being more than one and a half inches. This is made in long bands, and when wound up looks much like a coil of lamp wick. The loom is worked by men, and every village out here has its one or two weavers. From morning till near sunset in some retired corner of the village they sit side by side at their work, the ever constant "click click," even in the drowsy hours of the day, sounding upon the ear as the shuttle passes through the loom from one hand to the other. A friend or two may be sitting on the ground beside them, relieving the monotony by retailing to them the gossip of the place, and but for these they are alone.

Leaving the weavers, it is a common sight to see a woman sitting inside her hut close to the doorway busily spinning, the left hand holding the rough material upright on the end of a stick to the level of her head. From the rough material hangs by a single thread the spinner, a thin stick of wood weighted and balanced by a spherical ball of wood close to its end. This, kept spinning, draws out the cotton into a thread about twelve inches in length, which is shaped and tested with the 
fingers of the right hand, chalk now and again being used in the manipulation, and then it is wound round the middle of the spinner. Besides doing the work of spinning, the women gather the cotton from the plants and bring it in from the fields.

December 7.-Reached Ngala after a rather tiring march of twenty miles. On the way we saw several herds of hartebeest (Senegal). José shot a gazelle, and in the evening close to Ngala he obtained another, and a hartebeest. Ngala is a rather large town (Bere-Bere and Kotoko), but like all Kotoko towns it is extremely dirty and neglected. It is walled, and the walls, though now decayed, have at one time been very massive. There are also the remains of a fort, or citadel, about the centre of the town, from which one can overlook the whole town and surrounding country. Many slaves must have toiled hard to erect such works, but it was necessary in those days, when the stronger sections of the community were continually raiding the weaker, for the times were troublous, and such as might be compared with the times of the Barons in England. But now, out here, the days of slavery are over and "the white man is strong for all," * and as each year passes the rains obliterate little by little traces of the black man's former greatness.

The most interesting thing about Ngala is its huge earthenware pots. The biggest are four feet in height and three feet in diameter. At the top on the outside is scrolled a pattern formed by four zigzag lines. The present people know little about their origin, except that many years ago they were made by their ancestors, the So people, who came from farther east. This race have the reputation of being giants. According to tradition the pots were originally made for storing water in, I suppose

* A native expression.-ED. 
because in those days when towns were attacked great quantities of water had to be stored to meet the requirements of the besieged. Many of these pots are now used by the people as dye pits, and for that purpose are let into the ground. A good deal of dyeing is done here, the native gowns being dyed the favourite blue-black colour. Gosling stayed here on his way to Kussuri from our camp at Kadde on Lake Chad. In his diary he mentioned the remarkable pots. It seems curious that nearly four years after I should be staying at the same place. But fate determines the road for us.

I fear that San Thomé's fate is sealed; he is getting rapidly weaker, will eat nothing, but has an abnormal thirst; at times he coughs up frothy saliva; he is extremely restless, jumping up from his place beside me only to totter into some dark corner, where he throws himself down and goes off into a half comatose state, his head swaying to and fro as if he were stricken with palsy. It is dreadful to see him. At one time I thought it might be madness, but he has shown such patience and gentleness throughout his illness that I have dismissed the idea. I fear it is the fly-sickness.

December 8.-Stayed Ngala.

December 9.-Left, making an early start. Two and a half miles brought us to the River Gambaru, with a width of 250 yards and a depth of fifteen feet. It is now at its full, and the river people tell me that it is easy to reach Iuake Chad by it. All the natives I have spoken to say that this is a record year as regards the great volume of water in the lake; and it seems so, for the Gambaru has overflowed its banks, while all its tributaries are full and many backwaters have been formed. This is now the time when all the small rivers, which intersect this lowlying country, are full. The bigger rivers like the Shari 
to the south are gradually falling, and here the flow has reached the last stage of its journey before losing itself in the Lake. No doubt by this time Chad is about full up, and is consequently pushing back the remainder of the flow. This would account for the Gambaru and its tributaries being so high and for the many backwaters that have been formed everywhere.

While at Konduga I was told that at Ngornu the elephants had done a great deal of damage to the crops, having left the lake owing to the high water.

We crossed over the Gambaru on rafts made of bundles of ambatch roped together. The horses went over well, but there were one or two anxious moments with the camels. They are not good in the water. Two miles along the river brought us to a dirty little Shua and Kanuri village called Gubuge, where we stopped for the night. San Thomé is much weaker. In the evening while sitting at my table one of the village boys came too close, and poor San Thomé mustered up his strength and drove off the intruder of my quiet.

December 10.--In order to avoid the water on the main road we made a long detour in a northerly direction by a native path. We had not gone far when we sighted three gazelles, and José shot two of them with standing shots at two hundred yards, good practice considering the slender size of the animal. $\mathrm{He}$ is a fine shot, and the rifle he uses suits him. One cannot beat the Mauser carbine for this kind of work. Judging by the water on the road, the main road must be impassable. We had to cross no less than six rafines* and five marshes. After a very tiring march we put up at a small Shua village called Gallwui.

* A rafine is a tributary of a river; it is rather more than a stream.-Author. 
About four o'clock this afternoon poor San Thomé died.

It will be difficult for me to find such another companion. He was always faithful, and never left my side. Even at night he used to come of his own accord to sleep as close as possible to my bed, and he kept his watch well, for it went hard with any one coming near me; a torn gown and mauled legs and hands were frequently the penalty. A character like this is rare to find in the African dog. It seldom keeps faithful to one, the kitchen attracts it strongly, and then it ends by becoming the cook's dog rather than one's own. On the line of march he was always a source of great amusement to the carriers, with the reservation of the one who felt his teeth. Before starting on the day's march I used to tell the laziest man, just to wake him up, to put the leading chain round San Thomé. This order was always greeted with much laughter from the rest, and the next thing to be seen was the fellow careering down the road with rent clothes and San Thomé at his heels. But he is gone now and only the memory of a faithful companion is left to me. Africa is a sad place; here all things seem to die before their time, and the span of life can be reckoned only by the hour and day. The native mother is seldom destined to see the survival of all her children, for so many are cut short by fever in the early days. The favourite horse that has carried one over many miles suddenly collapses and dies from the deadly fly. Yes, all things die in Africa before their time.

I have buried San 'Thomé under a shady tree whose leaves throughout the year never fall. There will always be shade there as there will always be darkness in his grave. I suppose in the end the tree will die, but its great trunk could not fall across the grave of a finer spirit. 
Goodbye, faithful friend! Many days have you shared with me my tent and the toil of the day's march over mountain passes, through rivers, and through the desert heat. And where have you gone to now? Perhaps I shall know one of these days!

A curious coincidence happened to-day. About an hour before reaching Gallwui my horse-boy attracted my attention to a small heap of dry grass under a bush. Peeping out of it was the head of a small puppy which could not have been more than a few days old. I brought it along with me. Two hours after that San Thomé died. It almost seems as if the spirit of poor San Thomé had passed into the little puppy, and the curious thing is that this is the third one I have found in the bush. Maifoni, who died on my last expedition, was picked up by me in the fields, and San Thomé, it will be remembered, came to me in the same way.

December 11.-Another march through water, and a trying one too, a distance of six miles in seven hours! Our bag is a bush pig and two gazelles. In crossing the backwater of the Gambaru, close to the walls of Kuda, two of the camels before they could reach the firm bank sank in the mud up to their necks. We had to dig them out. The country through which we have passed, from the time of crossing the Gambaru, soon after leaving Ngala is a veritable home of geese and duck, the numerous backwaters and rafines of the bigger river attracting them in thousands. At the report of one's rifle flocks of redshanks, that have been softly running to and fro over the thick mud close to the water's edge, get up like one bird and "swish" away to some distant haven, while flocks of Spur-winged geese and whistlingduck, that can be numbered by the hundred, take a wide circuit overhead, passing one another in and out like the 
grand chain in the lancers, flying lower each time, and then when all is still again alighting once more on their favourite feeding-ground.

Like Ngala, Kuda, is another strongly walled place, and must have been in the olden days impregnable; for, besides the strong walls, which are over fifteen feet in height and very massive, the town is built on an island formed by the River Gambaru to the south-east and its backwaters. Like Ngala, it has a lofty fort, or citadel, and this I found out was built by the So people, the giants, and ancestors of the present race.

I obtained some interesting information about the giants from a very old Mallam here, named Arbari. I managed to arouse his interest, and his face quite lightened up as he told me all he knew; but it is very difficult to get information on subjects dating so far back, as everything has been handed down orally. I first made him tell me about the huge jars. He said they were made for water, and also for brewing the native beer in from the corn, the process of which, I suppose, was much the same as it is in the present day. He also confirmed my idea that the jars were made to contain water in the event of a siege. In those days wars and internal strife were rife, one town raiding another irrespective of kinship. As to the origin of the giants he was extremely vague. Apparently all that is known is that some centuries ago they came from further east, and that they were practically wiped out by a great famine before the advent of Laminu into Bornu. That these giants were the ancestors of the present Kotoko seems probable, for the Kotoko of to-day are physically very big, taking them all through, and the size of their hands is quite abnormal. The women are not so well developed. Around such men as these giants stories are bound to have been woven, and with the native 
weakness for exaggeration have been enlarged upon as they have been handed down from one generation to another.

According to the Kuda Mallam they were not Mahomedan. Each man would have from thirty to forty wives, and some over a hundred. They were of great stature, and so strong that it was possible for one of them to go into the bush, kill an elephant, and carry it back! And a march of three days for an ordinary man was made by them in one. They were not traders, but great farmers and cotton-spinners, weaving their bands of cloth much wider than those made at the present day. They fought on foot with spears and poisoned arrows. When a man died everything except his slaves and horses was buried with him, while on the death of the king his successor had to go without food and water for three days before he became king.

Their form of execution was by drowning. The name of their big king was Kannide, and he ruled over the following towns in this country-Pima, Muzugudi, Kuda, Bellami, Wasu, Afade, Alaf, Zu, Ngala, Ndubu, Zangir, Mudu, Muftu, Mutugu, Ran, Gilbi, Wurgi, Mobassi, Mulhui.

The bag to-day was two bush pig and two gazelle-the latter are very numerous, going about either in pairs or small parties, and often crossing the road not a hundred feet in front of one.

I took a photograph of an old woman, evidently the ladies' barber of Kuda, engaged in dressing the hair of a young Shua woman after the fashion of that people. The girl's hair had evidently not been dressed before, for it was roughed and touzled out like a mop-head, and made ready for the process. Also she held in her hand a bunch of her own hair, which I suppose she had collected at 
various times. Out of this the old woman made plaits, which she wove into the hair, parting them on either side, starting from the crown to the forehead; the end of each plait reached a little below the chin. There were five in all on each side of the head, while down the central parting were two broader plaits that passed over the crown down the back of the head, and the ends of these plaits were turned up. Goat's hair is frequently used if the woman has not sufficient of her own. In the older women the plaits often reach down to their breasts.

In appearance there is some difference between the Shua of this part and the race one meets with in Bornu; I think that the latter are really the descendants of the original Shua, for though much mixed now with the Kanuri and Kanembu, there are still many of the paleskinned type among them. On the other hand, the Shuas in the Kotoko country are very dark, and the women affect very much the same headdress as the Kotoko. In fact, we find that wherever the Shua has settled he has intermarried with the people of the land, with the result that racial differences have sprung up which are found in the Shua-Kanuri, Shua-Kotoko, Shua-Mandara, \&c. Without doubt the Shuas may be looked on as the wealthiest people of the land, possessing as they do large herds of sheep, cattle, and horses; indeed, in regard to this part of Africa they are rather like what the Jews are to us. Under these prosperous circumstances, though seldom leaving their dirty villages in the bush, except to attend the markets in the towns of their neighbours, they find no difficulty in marrying whom they please. Their life is a simple one, devoted entirely to the welfare of their cattle, which at night share with them the same roof. They grow no crops, but depend on their neighbours for grain, which they get in exchange at the big markets for 
their butter and oil. The inside of a stone fruit about the size of a small plum and called "adwa" by the Hausas is used by them for soup. It comes from a tree common in this part and generally growing side by side with the mimosa; it is thorny also, but on the whole stouter limbed than the mimosa, while the leaves are dark and crinkled. This fruit is sun-dried, and it is a familiar sight outside each dwelling to see heaps of it spread upon the roof of a rough framework which serves as a shelter to sit in during the heat of the day. The face markings on a Shua Kotoko woman are three cuts in the centre of the forehead, four below each temple, and three on each cheek.

December 13.-A march of twelve and a half miles brought us to a large Shua village called Orangulma. We passed through a well-wooded country, giving way in places to open plains, frequented by many gazelle. Besides this small gazelle, black pig and kob were observed. Our bag was seven gazelle.

December 14.-Afade, three and a half miles. José obtained a Senegal hartebeest out of a large herd.

Afade must at one time have been a large and strongly walled town, but to-day it is sparsely inhabited and is in a deplorably ruined state; nearly the whole north end is a mass of ruins.

The wall round the town is of great thickness, especially to the east and south, and is some twenty feet in height. This was built by the giants, the So people. Rabeh came here on his way to Dikoa and remained in the town for five days. On his approach the Kanuri, who were then in possession of the town, fled. Although Afade was a Kotoko town the Kanuri claimed rule over it. In the time of Omar, the Sultan of Kukawa, the Kanuri 
fought the Kotoko and exacted tribute from them. The majority of Kotoko speak the Kanuri language. The Kotoko marks are six cuts on each side of face and three in the centre of the forehead. Afade appears to have suffered considerably from wars. A great portion of the town was destroyed not by Rabeh, but by a Mallam named De Baba. At present the only information about the man I can get is that he came with a big army from the direction of the east during the reign of Chefu Omar. In appearance he was quite black and talked Fulani. After destroying Afade and taking from them some two thousand slaves, he went into Baghirmi, where he fought with considerable success, but was eventually killed by the pagans in the region of the Upper Shari.

December 16.-Dubabe (Shua), ten miles. Hartebeest and pig numerous. On the road we met four Mecca pilgrims on their return journey. They complained of Ali Dinar, the Sultan of Darfur, who relieved them of all their things, otherwise they gave a good account of the road. I shot a hartebeest and José two pigs. About half an hour from Dubabe we left them on the road, and on our arrival at the village I sent a camel back for them at once. But marauding Shuas had "made off" with the hartebeest, the devils evidently having watched me shoot the animal from behind trees; while the two pigs presented a sorry spectacle, for large white vultures had scented them and had cleared everything out of them from the back, till the carcasses had become nothing more than framework over which the skin was stretched. This is a fair example, I think, of the rapidity with which vultures can make away with dead animals.

December 17.-Kala Mulue seven and a half miles. A small and dirty Kotoko town. About one and a half miles to the east a branch of the Shari is visible. 
To make up for the disappointment of yesterday, José shot three pigs.

December 18.-The last trek into Kusseri. About two miles before getting to the station I turned off the main road to the left to see the battlefield where Rabeh was defeated and killed. A distance of five hundred yards along a native track led into the clearing which is the scene of the battle. The bush had grown up to a height of some two feet, but it showed to what a great extent Rabeh had cleared the ground. His front, still traceable by the old trench, faced a south-west by west direction, while his right flank rested on the river and his left on thick wood. From the front trench he had command of an excellent field of fire, but his rear and the left flank, both resting on thick wood, were the weak points of his position. The French attacked him on the left flank. About the centre of the position is a thick-leaved tree. Here it was that Rabeh met face to face with Lamy, both meeting their deaths in the encounter. Many bleached bones were scattered over the field.

About Afade, and on to Kusseri, especially after leaving Kala Mulue, there is much mimosa wood, and as one wends a way along the native path that winds in and out through this forest of little trees, some of which are starred all over with feathery puff-balls of pale saffron, a sudden breeze comes along and wafts from the blossoms the sweetest scent, recalling one for a moment back to England in the spring, but only for a moment and the scent is gone.

Though I have travelled now in Africa for many hundreds of miles the scarcity of flowers along the pathside and in the bush has always impressed me. Now and again I have passed a single flower or a tree in blossom whose beauty has arrested my eye, but days of marching 
have followed before I have met with it again. Here no wealth of blossom heralds the coming of the glad seasons as it does at home, where the wide fields ablaze with golden buttercups tell of the spring gliding towards summer, and the dell is decked with blue hyacinths to welcome the nightingale. There may be several reasons why flowers in Africa make so small a display. Perhaps their effect is lost in the immensity of their surroundings or the tender plants cannot survive the merciless bush fires, or there are not a sufficient number of the right kinds of birds and insects to scatter the pollen. The whole task seems left to the sunbirds, and these you will always find wherever there is a patch of colour that asserts itself through the spread of green or dried-up grass. See! how lightly they hover, probing so gently the hearts of the flowers with their scimitar-like bills the while the sunlight strikes their plumage with hues of paradise.

December 18.-Distance from Kala Mulue to Kusseri, ten and three-quarter miles. Kusseri is a walled town of considerable circumference, the side to the east resting on the River Logone. In height the wall is not far off twenty-five feet, but it is in ruins in places. The Fort, or Residence, is within the town itself and occupies the northeastern corner. The Resident, Lieutenant von Raben, gave me a good welcome; he had already pitched a tent for me within the fort. Jose and the men, with the camels and horses, are being put up by Musa, the king, in the town. Besides von Raben there are a doctor and six N.C.O.'s.

In the afternoon José left with a letter to the Colonel Commandant at Fort Lamy, and on it hangs the future. In it I asked for permission to travel by way of Fittri and Wadai to Khartoum. 'The reply 
which came back relieved my anxiety; it was most kindly worded, and ran as follows :-

"Monsieur,-Je serai trés heureux de vous recevoir demain et de faire votre connaissance. Voulez-vous me faire le plaisir de déjeuner avec moi à 11 heures et demi? Nous pourrons ainsi nous entretenir longuement de votre intéressant voyage.

"Bien cordialement votre,

“H. MoLL."*

December 19.-After a journey of twenty minutes by canoe I landed at Fort Lamy, and was met by the Commandant's Adjutant, Lieutenant Brulet, who at once took me to Colonel Moll, whose charming and gracious manner soon put me at my ease, and doubly so, since he speaks excellent English. He soon dispelled all my fears as regards not being allowed to reach Wadai. Everything

* Colonel Moll was at this time Commandant du Territoire du Chad. He was killed at the battle of Doroté by the Massalit Arabs in September, 1910. Apparently he had under-estimated the strength of the enemy, who made a sudden attack upon the French square taking advantage of the fact that it was opened for the camels, which had been feeding outside, to be brought into safety. The camels acting as a screen and ram, so to speak, the Massalit horse- and foot-soldiers broke right through the south-east corner of the square, those on foot keeping up by hanging on to the horses' bridles. All was now confusion, and the victory of the Massalit would have been complete had it not been for the heroism of Captain Chauvelot. $\mathrm{He}$ was on the north-east of the square, and when the enemy charged through found himself left alone. He thereupon rushed across the deserted square, and rallying a band of soldiers succeeded in driving off the enemy, who by this time had become demoralised owing to the death of their leader. For this deed Captain Chauvelot deserves the gratitude not only of his own but of all the white Powers of Africa, for, had the day gone totally against the French, there was nothing to stop the victorious Arabs' advance upon Fort Lamy and Kusseri, when, gathering fresh force as they went along from the rising peoples, like a ware they might have swept the country.-ED. 
was at my disposition; in fact, he made me feel that they regarded it as an honour for me to traverse their country. Commandant Brissot, who commands the troops, was also present, a weather-beaten man who had seen much service in Africa. From their accounts I shall have a most interesting journey, especially after Wadai, since nothing is known of the country between Abechir and el Fachir; in fact, I shall be the first white man to traverse it since the days of Nachtigal.

So my fears of the past three long months have gone! If the French had refused I had determined to try to get through at any cost, as a native with my face stained with permanganate of potash, which from trials I made can stain the skin to any depth of colour. Of course, I should have taken nothing with me, but would have lived on native fare and not washed for some sixty days.

December 20.-José is laid up. His sickness will prevent my leaving here for several days; the doctor says a week. Sent Braima, Chefu Sanda's soldier, to Maifoni with three boxes containing eighteen films and thirty-six plates. He is bringing back with him three tins of plates from those I left at Maifoni. Not knowing how things would shape themselves here, I came with as few things as possible.

December 23.-This was the big market day (Thursday), but it was small compared to some I have seen in Bornu. The people could not have exceeded a hundred, and were composed mostly of Kotoko and Shua. In all the markets out here the percentage of money taken is small-the people meeting together more for purposes of exchange. The Shua comes with his butter and oil with the intention of exchanging them for grain, so if a customer wants his butter he must first go and buy grain, and should the 
owner of the grain require another article than money, it can easily be realised what a lengthy proceeding a bargain can be.

December 24.--José out of bed. I think we shall be able to leave for Fort Lamy on the 27th.

A very strong wind from the north, at its height about one o'clock and dying down at three o'clock.

A great evening with the Germans, and the dinner was worthy of the occasion. The cakes were excellent and were made by the Resident and the Doctor (Liste). After dinner von Raben led me into the next room, where on a table a miniature Christmas-tree gay with many-coloured candles was displayed. At each corner of the table, under the shade of the tree, were laid groups of presents for each one of us; mine, I think, were the most substantial, consisting of three bottles of whisky and a Huntley and Palmer's cake, and in the words of von Raben " they were to help me on my long journey." The other presents were mostly jests.

The picture of this little tree recalled vividly the days of one's childhood. The same magic was there, and I plucked my present from the tree as a matter of course.

The fort at Kusseri is typical of German methods. Its front faces to the west and has a length of something like a hundred and eighty yards, while its back rests on the Logone. It is very massive, and the houses within it are practically forts within a fort. The amount of time and labour spent on this place must have been prodigious, and after each rainy season the repairs must be considerable. What is it all for, this great mud-built fort frowning upon a peaceful country? There is some excuse in preserving the fort at Dikoa since it is of historical interest. The population of Kusseri is very thin, and I should think that the impressinent of labour for the construction of the 
station has had a good deal to do with that. On the other hand, Fort Lamy has grown very much since I was there in May, 1905. There is nothing pretentious in the native town or in the houses of the station, and yet one has a feeling that behind it all more useful work has been done, and is going on, than with our German friends. The French seem to have a knack of collecting and keeping the people as a hen collects her chickens under her wings. The Sultan of Kusseri, Musa by name, is an old man and has not much of a following. Like Gulfei, Mandara, and Logone, he is independent of the Dikoa Sultan, an arrangement the latter does not like. Kusseri pays yearly to the German Government one mark on each inhabitant, and a certain amount of labour and grain; Gulfei, besides the poll tax, seven horses, one canoe, and one hundred labourers for two months. In the old days Kusseri paid tribute to the Sultanate of Bornu, and so did Mandara.

Rabeh stayed twelve days at Kusseri on his way to Kukawa, and Usman Uraj, his lieutenant, was left in charge till he was driven out by Lamy, who came from Gulfei. On the approach of Lamy on the latter place, Faderella, who was in command there, retreated on Logone. Lamy was eventually killed by Rabeh on April 22, 1900.

December 27.-Left to ford the river to Fort Lamy. We had to cross about a mile above Kusseri, and it was an anxious time when the camels were crossing, as the distance to the other side is great, at least a mile, and camels do not swim, but simply lie down in the water, so that if the cord attached to the lower jaw breaks and the camel gets separated from the side of the canoe, all is up with the animal. The whole crossing, camels, horses and all, was effected in about two hours. A good house 
was ready for me; while José and the men were put up by the Shereef, the chief of the town. Towards evening Colonel Moll came round to me and asked me to dine with him the next day.

December 28.-There is a store here belonging to the Compagnie Ouhame et de la Nana, the same as that from which we bought things at Krebedge in 1905. The company has taken over the entire fleet from the French Government here, supplying the latter with what they require. They run the boats up the Logone as far as Ham, whence a land transport is made to Lere on the River Kebbi.

The Germans also run native canoes up the Logone as as far as Bongor, and then a land transport of twelve days to Garua ; the journey down the stream takes only four days.

The Nana Company has accepted my cheque, and I have bought a few stores; but everything is very dear, a bottle of claret costs six francs. The money here is par excellence the dollar, but the five franc, one franc, and fifty centimes pieces are taken. The dollar is worth three francs. Light and dark blue beads are taken also, ninety strings going to a dollar, and fifteen beads to each string.

The Colonel gave me some interesting details of the fighting at Wadai. An enormous amount of guns and powder was taken. The Sultan, however, managed to make good his escape with a large following into the region of Borku. There were two fights; the first on June 1st at Chauk, not far from the town; and the second on the following day in Wadai. Captain Fiegenschuh was in command of the first reconnaisance. During the fight he was severely wounded in the neck, so the command was taken over by Lieutenant Bonneau. The 
other losses were two tirailleurs killed and six wounded, two auxiliaries and five irregulars wounded and two horses and a camel killed. The enemy's losses were 350 killed and the same number wounded.

At the taking of Abechir, on the 2nd of June, the effective force was Lieutenant Bonneau in command, with three lieutenants under him, six sous officiers, 211 tirailleurs, thirty-nine auxiliaries, 300 irregulars, and two guns.

In the fight the losses were, one sergeant wounded, one tirailleur dead from wounds, six gravely wounded, eight slightly, four auxiliaries killed and five wounded. The enemy lost 450 killed and 400 wounded.

On the battlefield of Chauk the enemy left fifteen guns (rapid) and one thousand cartridges, and at Abechir a hundred guns (rapid) and several thousand cartridges.

The total amount of guns, \&c., taken from the Sultan was ten cannon, two hundred shells with grape-shot, thirty thousand cartridges, eight hundred kegs of powder, caps, \&c.

I have been told that Italians were responsible for bringing the guns and ammunition to Abechir, but I think it is much more likely that it was Greek traders from Tripoli and Khartoum.

So Abechir, that has been for so many years the bugbear of the French, has at last fallen, and considering the large amount of ammunition in the place, the little resistance that it offered was extraordinary. But I fancy that for some time past the Sultan was losing followers, many going over the border to us, probably to Ali Dinar.

The French told me that after the occupation they received an insulting letter from Ali Dinar, asking them when they intended to leave Abechir, and saying that if 
they wanted to fight him also they must come against him with at least two thousand men. This is rather surprising, for I was under the impression that the Sultan was friendly to all white men, though especially to the English. I wonder how he will receive me?

December 30.-Left Fort Lamy for Abechir. The expedition is now pretty well compact, and I think that the men are all satisfied. Before reaching Kusseri $I$ had to get rid of one, a Bere-Bere, who was always trying to persuade the others to go back, saying that the Wadai road was " no good," \&c. Ever since he left the men have been all of one accord. It takes some little time to know whom to take and whom to get rid of, but after a week or two of marching it is fairly easy to pick out the best men.

The expedition now consists of four camels, seven horses, and ten men, whose names are as follows:-
1. Alan na Gudu
(Head horse-boy)
(Bassama)
2. Dogo
3. Mamadu
Horse-boy
4. Abatcha
5. Mustapha
6. Adamu
7. Jololo
8. Bakko Lafia
9. Gibberi
10. Mama

$"$,
$"$,
Camel-boy
$" \prime$
Cook
Boy (mine)
(José's)
(Kanembu)
(Hausa)
(Dikoa)
(Kanembu) Deserted.
(Hausa)
(Kotoko)
(Hausa)
(Shua)
(Hausa) Left.

The horses have come through very well. My journey to Kusseri was made just at the right time; a little earlier I should have had to pass a big fly-belt between Kala Mulue and Kusseri. During the rains from June to September no horses can live at Kusseri; they are all sent to Dikoa.

Our first stop was outside a little Shua village, as dirty 
as usual, called Njaire, about seven miles from Fort Lamy. It made quite a picturesque camp under a belt of shady trees, spots which frequently relieve the monotony in the otherwise mimosa-wooded country.- "Toujours les épines," as the French describe it.

This country, as far as we have gone, has quite a different aspect from that of Bornu. It is thickly wooded, in places giving way to more open, park-like expanses with groups of trees of fair growth, generally the mimosa and "adwa" tree.

The whole ground is a clear straw colour, being strewn with dried-up grass that has been beaten into little bits by the feet of many cattle, a uniformity of colour which is not unfrequently broken in the distance by spots of bright green that mark the presence of water, if not now, at least in the rainy season.

December 31.-Made no start to-day as the camel "Kiari" has a bad foot. 
January 1.--Once more a New Year. May all those dear to me at home have lived to see its beginning and may they live to see its end! I do not know what is in store for me, but I hope to reach Khartoum by the end of April.

January 10.-Our second day's march brought us into thick forests of mimosa, very different from the fertile scenery of Bornu, where the eye wanders over vast stretches of cultivation, the presence of tree-life only marked by dark bunches here and there of the thick figtree. But here the gaze rests for a time upon the delicate tracery of the thorn-trees, almost toy-like in their appearance, their brick-red stems and branches so lightly fringed with bright green leaf and crowned with flower-balls of pale saffron that lend a strange contrast to the forest, but all the trees are not like these, for the stems and branches of some are a pale green.

Besides the endless winding through thick forests of 
thorn, we now and again had to cross reedy strips or rather channels formed by the backwaters of the $\mathrm{Ba}$ Ligna. These in the Arab tongue are called "Massé," as opposed to $\mathrm{Ba}$, meaning a river. Amongst the thorn forest there are small groups of peculiar looking trees, now leafless, and their bark has almost the look of silver. They appear from their stunted limbs and branches to have stopped growing before their time and remind one very much of miniature baobab-trees.

Up to the present there has not been much game on the road. This is a pity, as it makes all the difference to the "pot." I leave this work to Jose when on the march, as it is difficult for me to leave the road after any game as I am occupied with my mapping. Camels come in now very conveniently, for as a rule we can always manage to put on one of them an animal bodily, without having to cut it up. Bush pig, the red-fronted gazelle (rufifrons) and Senegal hartebeest are all the game we have seen, and these not in very great numbers, for the country is too enclosed, and water just now is scarce. As regards bird life, the birds are practically the same as I obtained in Bornu. Africa is such a bad place for the memory that I shall not attempt to remember all the scientific names. I have seen the black and white hornbill, the little rufous thrush (Sylvia), the bush blackbird, long-tailed glossy starling (Lamprotornis), glossy starling (Lamprocolius), coly-bird (Colius), Petronia, carminebreasted bee-eater (Merops), small green bee-eater, longtailed dove (Anna), black and white crow (Corvus), rock-pheasant (Ptylopachys), finch lark (Pyrrhulauda), Telephonus, white-winged starling, weaver starling, anthus, roller (Coracias caudatus), Melanobucco vieilloti, ground hornbill, Bornu quail, Coturnix, Columba 
guiniensis, and hosts of guinea-fowl. It is no exaggeration to say that I have seen sometimes nearly two hundred in one bevy; they have literally blackened the ground. They are a great nuisance as they prevent one's approaching game.*

The natives catch a great number by netting them in the pools where they come to drink. From the top string which surrounds the pool not more than a foot above the ground are hung rows of nooses, which tighten round the bodies of the guinea-fowl as they attempt to get through them, and then they are pounced upon by the native fowler, who sits hidden at some distance in a rcugh straw shelter. Another method employed is to poison the water with a certain kind of tree bark which is boiled down and then put in the water. It has the effect of intoxicating the birds, and then they are easily knocked on the head.

I shall not go through the doings of every day's march as many pass without incident and one does not meet with new things every day.

We are still in the land of the Shua. On Jamuary 5th, after a long, hot, and dusty march, we turned off the main road and put up outside a small Shua encampment. It consisted of a large circular space formed by rough shelters made of large woven mats stretched over a slight framework of sticks, each dwelling having the appearance of the back of a gigantic beetle. Owing to the waterless nature of the country these people are constantly moving from one place to another, ever seeking a supply of water and food for their cattle. Their encampments are soon shifted and they are quickly on the move. The big mats that form, as I have * The Arab name for the guinea-fowl is Aswella.-Autror. 
described, the roofs of these primitive dwellings are rolled up and hung as a rule on either flank of their bullocks, together with their other belongings. It is a picturesque sight when on the march to come suddenly face to face at some bend of the winding road with a column of these people on the move. A string of slowswaying bullocks piled up with all the odds and ends of the nomads' wants-mats and skins, calabashes, drinking-gourds containing water that is foul-smelling with the odour of their rancid butter, and roughly sewn leather bags bulging with grain. On the top of all this motley collection of goods is perched the driver, generally the wife of the owner of the ox, and behind her perhaps one or two tiny children, while walking along by the side of the oxen are shepherd-men and skin-clad boys, shouldering spears, with long blades glinting in the sunlight.

At the encampment we stayed near, I was much struck with the number of pale-skinned people. To my mind they represented more nearly the original Shua than those I have met with in the Kotoko country and elsewhere. The very fact of their wandering life, almost entirely confined to the bush, prevents them from intermarrying so much with the people of the towns, as in the case of the Kotoko-Shua who live in permanent villages. They correspond, in fact, to the Borroro-Fulani, and might be called in the same way the Borroro-Shua.

Our resting-place for the night is generally a Shua village or encampment. The huts are dirty in the extreme, reeking with cattle urine, but after a time one gets used to anything out here. The incoming of the cattle marks the fall of the evening. The sun goes down amid a rosy splendour that fades upward into the palest 
yellow, then into the green of a duck's egg. A cloud of ascending dust away yonder outside the village foretells the home-coming of the cattle and sheep, that low and bleat softly with tired contentment. Nearer rolls the cloud, black, slow-pacing objects loom out, and in a short time one is breathing dust, and everything is enveloped in it till one can hardly see across the open space, formed by the huts of village, where the cattle are to rest for the night. Then the dust lifts, and the whole large space is disclosed to view, this time alive with cattle of all kinds-oxen, sheep, and goats-while many skin-clad herdsmen can be seen busy tethering their charges to big stakes driven into the ground. This is not done without a little trouble, for sometimes stubborn oxen will break away from the rest and go wandering about the village. A stranger will always arouse their curiosity. Often has an ox come and sniffed my hand and then almost charged at my table. The hubbub subsides, and the motionless forms of prostrate cattle mark the peaceful end of their weary day. Then in the darkening fires peep out in front of every hut, and recumbent and squatting figures are thrown up distinctly and all their gestures can be noticed. One is telling to the others a tale of old days; another shows his gleaming teeth, and another moves to stir the fire into a blaze. Soon the evening wears into the night, and then there is not much peace about an Arab village, for as soon as the noises of the cattle have subsided and the women have left off pounding their corn, the night is made hideous with the incessant barking of the pariah dogs. They are indeed loathsome animals; illshapen, and half starved, they run about the village throughout the night, frantically picking up what offal they can find. One bark is enough to set every dog in 
the village yelping for no reason at all, and it makes one shudder with repulsion to hear them fighting among themselves, for the pent-up venom of years seems to be expressed in their snarls. Then there are other noises to get accustomed to-the restless bleating of lambs that for the time being have lost their mothers, the deeper low of oxen, the cry of a baby at the breast, and the shrieks of a woman being beaten by her husband. And so the unwilling listener lies hour after hour wide awake, and each sound as it comes seems to bite itself into the brain, and when at last the deep sleep of utter weariness comes to him in the early hours of the morning all the sounds are echoed back again in his dreams.

After leaving $\mathrm{Abu}$ Idielli we travelled for a time through a different forest from that of the mimosa : rough, ill-grown trees with branches much contorted and opaque leaves of an oval pattern, the whole tree reminding one very much of the Shea butter-tree. Long elephant-grass burnt to a straw colour was everywhere.

The last few days have brought us into a very interesting country. All the villages are deserted, and the people have made encampments in the bush wherever they can find water. What water there is is terrible, for there are no wells, and the water is obtained from stagnant ponds, which out here are generally marked by the presence of acacia groves. At these the cattle come to drink, standing knee-deep in the water, and in them the people wash themselves, and from them they take the water for drinking purposes. So the state of the water can easily be imagined. It is a poor country, and the French must get next to nothing out of it. Certainly they work it on the cheapest lines possible. There are no roads, the posts are far apart, and run 
with the minimum number of officials, and the soldiers are a ragged lot. The transport is by oxen supplied by the Arabs and Shuas, who receive the payment of two dollars per bullock for every six days of transport, and no payment is given to villages who supply food to a column on the march. So travelling out here on the French lines costs next to nothing. I always pay for what I get, the expenses generally coming to about a shilling a day for feeding ten men and seven horses.

At the Shua village we stayed in, after Abu Idielli, I had a disagreeable experience ; I found a lot of powdered glass in one of the rissoles I ate for luncheon. I called José, who confirmed my opinion. I cannot believe it was done on purpose, as in my case there could be no motive. This is the usual means employed by the natives to put white men out of the way. Another method is a poisoned needle, with which a prick is given to the victim at a convenient opportunity, such as when he is mounting his horse.

January 12.-A long march, something like twentyfour miles, brought us to Mwato. This is a deserted French post; two white men are buried here. The native town, which is a large one, is Bulala, and lies at the base of a small isolated group of stony hills from two bundred to two hundred and fifty feet in height, which rise out of an open plain. They are the home of many black and white crows. The day after our arrival was the market day. Towards noon it was at its height, the greater part consisting of women, who either arrived with their wares on bullocks or carried them in grasswoven baskets hung from each end of a stick balanced 
over the shoulder. The quarter of the market where the women congregated was almost unbearable from the smell of rancid butter-oil with which their hair was soaked, and to such an extent that it streamed on to their shoulders and down their backs. Their coiffure is remarkable; they wear the same side plaits as the Shua, but the centre plait is much exaggerated, running over the crown in the form of a great question mark, thus: ?; the front end is terminated by an oblong piece of wood encased in leather. This extraordinary ornament is worn till it practically falls to pieces, often being kept on for several months before it is replaced by another. In a woman greatly adorned the plaits of hair that hang down on each side of the head are rolled and plastered over with grease till they look like elongated sausages.

The Bulala are the "kurdi," or bush people, of the country. They are poor, and though they possess towns of their own, many are found living with the Arabs, who are the owners of all the stock in the country. They have a language of their own, but also speak Arabic. The way a woman of this tribe greets her husband or a "big man" is pretty. It may be that the husband is returning from his day's work or from some business in a neighbouring town. The woman, as he enters the village, runs to meet him, and then drops on her knees before him; simultaneously the man does the same thing, and they kneel facing one another, the while she gives him greetings, followed by questions as to how he has fared throughout the day.

At the market we were able to buy for dollars the money of the country, which is strips of the native cloth. Ten strips go to the dollar, one strip being the 
length from the tip of the finger to the elbow-joint, measured four times. The Arab name is gabbuk. It is bulky stuff to carry about. Though the dollar, of course, is almighty throughout the country, it is useless for small purchases. This is a great drawback sometimes, for one gets a "dash" in return, which is often not worth a dollar. The French coins are only accepted by the natives in Fort Lamy and its neighbourhood, and I suppose this would also apply to other posts. With the French method of travelling money is not required, and I suppose this accounts a great deal for the small circulation of their coins, and, besides, the dollar is preferred by the Arabs to anything else.

Towards evening I went down with fever and vomiting, the same form as I had at Konduga.

January 14.-Another return of the fever with much vomiting; I am inclined to put this down to the north winds, which during the last few days have commenced to blow very strong. The beginning of the harmattan heralded my attack at Konduga. It may be a form of influenza. There are certainly no mosquitoes about Mwato.

Jamuary 16.-Left Mwato. The day before the Kanembu, Mustapha, "did a guy." $\mathrm{He}$ evidently joined a Kanuri caravan which was on its way down from Fittri. Funk was at the bottom of it, for we afterwards heard that the headman of the caravan had held forth to him about the waterless condition of the road in front. This makes the fifth Kanuri who has failed me. They are a worthless lot.

A few days before this I had to dismiss Mama at a 
moment's notice. I felt rather sorry for him in the morning, as he turned to go, saying "goodbye" to his old companions with tears in his eyes; but he shouldered his little bundle bravely and started off to tramp alone the long journey back to Nigeria. An incident of this kind always upsets me for some days to follow. Our numbers are now reduced to eight.

Although the character of the country hardly differs in the main, the almost eternal mimosa-tree gives way in places to other growth, and groups of the "dum " palm, with clumps of the young plant spread here and there amongst the tall dried-up grass (Hausa, gabar rua).

The nut of this palm, about the size and colour of a red plum, is eaten by the natives. It is very hard, and the outside only is eaten, being literally gnawed off the big kernel. It is a poor substitute for sugar.

January 18.-Immeda, a small Bulala village about four days from Yao. Our stay here was marked with disasters. José arrived ill and in great pain, the result of former illness and neglect. He was in great pain for two days and nights. I could do but little for him, except give him morphia and salicin. The third day he mended. To add to this trouble, one of the camelboys came home the second evening, as the darkness was falling, to say he had lost the camels. It appears that at midday he felt hungry, so left the camels a good half-hour from the village to take care of themselves while he went to forage for "chop." During his absence his charge also went aforaging to wider fields. There is no doubt he made a frantic search after them through the thick thorn bush, remembering a previous sore back, for he returned to camp with his clothes full of tatters, 
as if he had fallen into a gooseberry bush. With all the men I could get I posted off to where the camels were last seen. Just outside the village we found two of them lying down in a corn patch, and this left two to be found, and they were the best. As soon as we got away from the village I made the men spread out on either side of the path, and search the ground by the light of surrounding bush fires which the village people had lit. But after a good hour's search nothing came of it, and, realising the hopelessness of the hunt, we returned to camp.

The whole of the next day men scoured the country in all directions, but without success, and it really seemed as though it were easier to find a needle in a bundle of hay than to catch the camel's eye.

Towards noon of the following day, just as I was starting in the heat on a second search, I looked up and beheld one of the truants being driven into camp, but there was still Kiari (Kanuri for "old") to be found, and he defeated our efforts for another day. Towards evening of the next day the manner of his capture was as follows. An old man gathering simples in the bush came upon the place where Kiari had slept the night before. But being too old and blind to follow up the spoor, he sent in his little boy to tell the Sultan of the village the news. The Sultan, though well past the age of sixty, and thin and wizened, at once mounted his Rosananté and ambled off with two trusty followers to track the camel. Just at dusk he came in and reined up his steed in front of where $I$ and José were sitting and shook his spear in triumph.

The next moment the time-worn head of Kiari came round the corner, in a dignified brown study, and indifferent to all the fuss he had caused. 
January 29.-José was well enough for another journey, and we put up at an Arab village, called Abbagowada, where there are wells, a great thing after the mud we have been drinking. After drinking one's tea a thick layer of dirt always covered the bottom of the cup.

We really had to leave the last place because the water was nearly finished. The people were making frantic efforts to reach water by making a well, but they had not succeeded up to the time when we left.

February 1.-José went out to look for giraffe and came upon a herd of seven. He hit one of them in the neck as they were going away. It fell, but on his approach got up again and made for him, striking out at the same time with its forefeet. A second shot was its coup de grâce. It was a fine male, and there was great rejoicing in the village, and the meat fed the whole people. From Fort Lamy up to this place the bag has been two pigs, twenty-one gazelle, and one giraffe.

February 3.-José's boy, Abatchi, ran away during the night. $\mathrm{He}$ is a Kanuri; further comment on these people is useless.

My numbers are reduced to seven. It reminds one of the "ten little nigger boys." José left this morning in hot pursuit, but I have my doubts as to whether he will catch him.

February 4.-To my surprise José returned early this morning bringing with him the miscreant, Abatchi. His manner of catching him was quite skilful. It appears that he made for Immeda, the place where José was so sick. Here the water is a good half-hour from the village. Jose found out that he had not passed the village, so was evidently hiding somewhere outside. $\mathrm{He}$, 
therefore, sent on one of the men to patrol the road in front to the next town and so cut off the boy's progress in that direction. Another man was sent to guard the water. The little devil certainly had taken pains to baffle pursuit. So that his footprints might not be traced, José found that he had constantly broken his spoor by taking off his shoes and then after some distance putting them on again; also by doubling back on his steps and going from one side of the road to the other. He had also taken with him a piece of paper, which he showed to some men on the road who asked him where he was going, saying he was carrying a white man's letter. The same men met José and told him that they had met the boy, so José immediately sent Dogo on ahead as fast as possible.

Dogo practically arrived at the village the same time as the boy, who, catching sight first of his pursuer, as the man was on horseback, hid in the bush. He then to his dismay saw Dogo pass through the village on to the road beyond, thereby cutting off his way to the next town. The boy then crept round to where the people had sunk a well and hid in the long grass close to it. On his arrival at the village José gave orders to the Sultan to have men posted on the look-out. It was a hot day, and towards four o'clock the boy, parched with thirst, made an attempt to reach the well, but he was detected leaving his place of hiding. The game was up, he gave in quietly, saying " Not much longer. I should have died of thirst." The boy has had a lesson he will not readily forget, for besides a flogging he had field imprisonment Number 1 for three hours in the village-that is, being tied up by the hands to a branch of a tree in a standing position. This practically answers to the stocks. It has an excellent effect, as there is hardly a punishment the 
native hates more than being made a butt for the laughs and jeers of all the people.

February 5.- My bed has come to an end. I have everything to say in favour of the "Compactum" campbed. You cannot better it. With such continual marching as I have had to do the canvas top should be doubled, and in its present form I should not reckon its life at more than a year when continually used on the trek.

Now I lie upon a native mat, rather hard, but my bones will have to get used to a good deal more before I have finished with them. The night's rest is disturbed by rats running over one, while in the thatch of the huts there are snakes that might come nigh one for warmth.

At the place where José was so sick ten Hausas, seven men and three women, arrived one evening on their return journey from Mecca. It is wonderful how these people get about. They were natives of Bautchi, and so far the journey had taken them five years. Several of them had donkeys. It is the humble "moke" that as a rule takes these pilgrims to Mecca. Their travelling expenses are not very heavy, for they are always given food and quarters for the night at whatever village they stay in. As a rule the "big men" of the village club together to supply their needs.

February 6.-Jernabarra. We are now amongst the Bulala people; their big king lives at Fittri, which we shall reach to-morrow.

On the road to-day ten fine ostriches, all mantled with great waving plumes, crossed the roads ahead of us. José was after them like lightning and wounded one, but not enough to stop it, unfortunately. Unless one disables them in the leg one stands but little chance of getting 
them, for if they are hit only in the body they go a long way before they fall, and the course of a wounded bird is so erratic that the hunter in following it runs a great chance of getting lost.

February 7.-After leaving Jernabarra the road emerged on to a vast open plain, a great straw-coloured expanse that met the sky, and we knew that we were approaching Lake Fittri. Crested cranes moved here and there over the plain, while overhead in the far distance flights of plover and redshank kept passing from the northward towards the Lake, now mere specks in the sky, now so distant that the flocks seemed to dissolve into mere wreaths of smoke. It is good to gaze over a great boundless tract like this. It refreshes the brain and spurs it on to swifter flights of thought.

After a very tiring march of twenty-three miles we arrived at Yao.

This is a French post with one officer and about fifty men. We found it very deserted, for a sergeant with half the men had left for Abechir, in the neighbourhood of which the French have met with a disaster. It appears that Captain Fiegenschuh, who was the first man to enter Abechir, left on a reconnaissance into Dar Massalit, a kingdom about four days to the southeast of Abechir. He interviewed the Sultan, who at once showed himself friendly. The French force then bivouacked for the night, but under the cloak of feigned friendship the Sultan had collected all his men and hidden them in the surrounding bush, and at a given signal the French, unsuspicious of this treachery, were surrounded and overpowered by superior force. Captain Fiegenschuh, two lieutenants, two sergeants, and over fifty file were massacred. Nine men effected their escape to tell the news at Abechir. The fight, or 
rather massacre, occurred the next day. It appears that the soldiers had some warning that an attack was imminent, and a rush for arms was made, but Fiegenschuh forbade any resistance. "C'est magnifique, mais ce n'est pas la guerre." One must pay back Arabs in their own coin.

I think I have understood this situation, and I feel sorry for the French, since they have to suffer for the foolhardy action of one man, who has brought disaster close to the gates of Abechir. Fiegenschuh was a man with whom courage outweighed all other considerations; he did not recognise discretion. Left in command at Abechir after the departure of Commandant Brissot, instead of devoting his efforts to consolidating the power of the French in the capital, he marched off on an armed and quite unnecessary reconnaissance into the country to the east, a rash exploit which terminated in the fatal results I have already recorded. That is the situation.

By this foolhardy action the French are plunged into another war which at this time they can ill support.

They now are scraping up all the men they can. Both the posts of Yao and Athi are to be left in charge of Sultans. Every available soldier and man has orders to proceed to Abechir. I can only comment upon and make deductions from what I have heard, but the situation is serious. By the French disaster the Sultan of Dar Massalit will have gained in power, both in arms and prestige, and consequently the French will have to look to it well that they do not suffer another reverse. Should this happen, Abechir would in all probability rise against them. A disaster of this kind would have far-reaching results.

On the map Dar Massalit is marked as being almost 
close to Abechir (el Fachir route), so this does not look very hopeful for me. It seems that the French have made a mess of it. What were they doing in that direction? Dar Massalit is within the region of British influence.

When the French entered Abechir it was deserted. Every one had made good his escape. It was extraordinary what was left behind, not only in the ling's palace, but in many of the "big men's" houses; most costly blankets and other stuffs of European manufacture, all having come from Tripoli. After the occupation it was ten days before any sign was made on the part of the inhabitants to come into the French. Abechir cannot be said to be subdued, for all the men of influence have escaped, and I think that they are only waiting for some reverse to the French arms to come back and retake the place. Abechir has for years been the refuge of all the "bad hats" under the African sun. Situated as it is, in the very heart of Africa, it has become the asylum for all those who have had no use for the New Africa. The occupation of Abechir by the French has been to scatter all these parasites over the land, just as a lump of quicksilver breaks up when touched by the hand. Many of the roads are infested with bands of robbers who raid travellers and take from them cattle and horses. The Commandant, who passed up to Abechir the other day, had his horse taken during the night. I wonder what chance I have got with my seven horses! The French have no force to put this lawlessness down. The robbers go off into Kanem with their booty.

After leaving Jernabarra the ground rises very gradually up to Yao the whole way. The post of Yao, which is small but compact, is close to the Bulala town, beyond 
which is the Lake. Directly behind the post and to the north of it is a remarkable kopje of stone, something after the nature of granite, the only prominent feature in the vast open plain that surrounds the Lake. In the vicinity of the Lake much "Mussakowa" is grown; the soil is of that chall-clay which favours it.

From the top of the kopje the water of the Lake can be seen, with the silver streak of the Bahr Batha flowing into it at its eastern end. About the middle of the rainy season, which is from May to September, the Lake begins to fill up, spreading over a great tract of country, and almost right up to the town of Yao itself, forming in many places backwaters, called in Arabic "Massé." At the present time the open water itself must be at least a mile from the town, but it is impossible to reach it, as vast swampy reed-beds enclose it.

The town of Yao is the headquarters of the Bulala Sultan, Assan. He is a big, strongly built man, and is most kingly in his movements. His head is massive and his features blunt and of a knotty character, like the bark of some time-worn tree. Physically, the Bulala are strong and well built, both men and women. There is a certain bull-dog expression in their features, but they are not reputed to have much courage.

The French arm a certain number of the Sultan's men and supply them with cartridges. They profess the Mahommedan faith loosely, although there are Mallams who make the journey to Mecca.

The majority of the older people speak Arabic, but the younger generation have an imperfect knowledge of it.

The Sultan made our coming the occasion to ask José many questions about the English; he had heard that our King came first in importance among the white 
races; was this so? He then said that he heard that the English had all the biggest places in Africa; from the east, from the north, and from the west people at different times had come through his kingdom and told him so. The French were brave and had killed Rabeh, but the English had taken away the Sultan of Dikoa (now Sultan of Bornu) under the very eyes of the French, whom they told to retire to the line of the Shari, and then afterwards they gave the country to the Germans. This is the native interpretation of how the Germans came to occupy that portion of Africa between Dikoa and Kusseri and the southern portion of Chad, or the German Sudan as it is now called. This version was brought about, first of all, by McCarthy Morrough's entering Dikoa and taking away under cover of night Sultan Garuba and all his belongings at the time when the French occupied the city; ${ }^{*}$ then subsequently by the retirement of the French to the Shari in favour of German occupation, which had been previously agreed upon by the three Powers.

The Sultan also took a great interest in my rifle, as he had never seen one with a magazine before. He insisted on José going through for his benefit the loading and unloading movements. I made a good photograph of this scene.

February 8.-Left Yao for Seita. The day before, the Sultan promised to give me a good guide, whose duty it

* In "From the Niger to the Nile" the author relates how Captain McCarthy Morrough by a brilliant coup de main enticed Garuba, whom the French had made Sultan of Dikoa, out of his alien palace one night, brought him over the border to Maifoni, and made him Sultan of Bornu. Garuba, it must be remembered, is the son of a former Sultan of Bornu, and was captured and made a slave by Rabeh, and on the defeat of the latter by the French was freed by them and made Sultan of Dikoa.-ED. 
would be when on the march to walk in front of me and point with his arm in the direction of the road whenever I required to make an observation. He also would have to tell me the names of villages, \&c., we might pass on the road.

This morning our guide turned up. From his looks he might have lived on the earth since the days of the Flood. However, in spite of the disabilities of age, I gave him credit for sense, knowing full well that in the black races the power of reasoning is seldom to be found in the young, but I was doomed to disappointment. When we got outside the station nothing would make him show me the direction of the road; he seemed mesmerised by the little instrument (prismatic compass) I put up to my eyes. He turned out a miserable failure, and I sent him back from Seita.

February 9.-The Bahr Batha, which falls into Fittri, passes close to Seita. It is now nothing more than a sandy bed about twenty yards in width. There is thick wood lining either bank. Just after crossing it José saw two large antelopes, but failed to come up with them. They have the colour of a donkey. The natives say they are locally distributed wherever the wood is thick and the ground swampy. The Arab name is Nyellit. I should not wonder if it were a new species. Later in the day José saw two herds of giraffe.

I sent off to-day a letter to the Commandant at Abechir offering my services and those of my expedition in their present difficulties. I think that being in their country, and seeing that they are collecting every available man at Abechir, I could not well do otherwise.

February 11.- We are now amongst the Middogo people. Their principal town is el Birni, at the foot of a 
stony hill much the same as that at Mwato. It is about two hundred and fifty to three hundred feet in height, a mass of pale terra-cotta boulders, so closely packed that the steep sides of the hill look as if they were mosaic work. The people get their water from a spring in the side of the hill, quite a hundred feet up. Boys and girls shouldering pots may be seen jumping from boulder to boulder, to and from the water. In appearance the Middogo closely resemble the Bulala, but they have their own language.* The hair of the younger men is often long and matted, giving a somewhat savage appearance to the face. The village here (el Birni) is remarkable for its many large earthenware pots, five to six feet

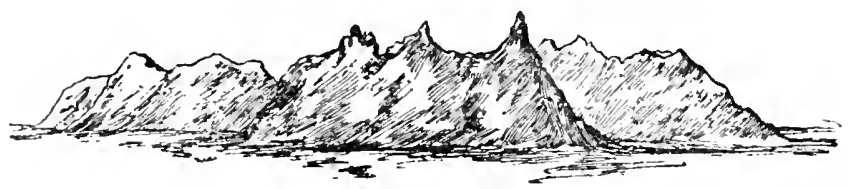

The Middogo Hills as seen from Dulgaia.

in height. They are terra cotta in colour, and are very graceful in shape, reminding me of Grecian vases. They are used for grain stores.

The Middogo are a fairly large tribe. Before the French occupation of Abechir they used to pay tribute to Wadai in cattle, horses, and slaves. In the past they were often raided, and, judging by the scarcity of young people in the villages, they must have suffered a good deal. The women do their hair either after the Bulala or Wadai fashion.

From el Birni a vast view to the south over a flat country, covered with low bush of nondescript growth, meets the eye, but this dull expanse is relieved by

* They speak the Konga language-Autuor. 
isolated groups of hills in the nearer distance, and still further off, to the south-east, by the blur of the Abou Telfane Range.

Looking from west to east the hills are as follows: Mienyi, Gia, Mattiyi, Azzi.

The height of el Birni, according to my aneroid, is 3,200 feet.

February 12.-Stayed el Birni. Throughout the night there was a very strong wind, which did not drop before nine o'clock.

Have started collecting. I find the little gun not at all useless, it kills well at ten yards. Close to the hill and about the village I found a Fringillaria, closely allied to F. tahapisi, but distinct.

This is the first time I have seen it, and I have hopes it will be new. The throat of the male is very hoary. I obtained three specimens, also a specimen of Pyrrhulauda melanauchen, two Colius macrurus. I think I shall find pretty well all the Bornu species going right across to the Nile. From a geographical standpoint there is nothing to prevent this.

February 13.--Left el Birni. The old Sultan here is a good specimen of the old generation, but I think he and his people have been harassed a good deal in their time. His vision of ending his last years in peace has had a rude shock in the last disaster to the French, whom he firmly believes will be driven from Abechir, so that the old régime will come back again. Though old and bending towards the grave, he insisted on mounting his horse, and accompanied by his followers, escorted me from the village. Outside he stopped and dismounted, and with a concerned expression on his face, which was pinched with the keen air, he beckoned me and José to come to him, 
out of earshot of his followers, and with gravity asked whether we were going to Abechir, and on what side we were going to fight, on the French or on the Wadaians. He had always heard the English were a very strong people. He shook his head dolefully and said the French would be driven from Abechir.

On the road José shot four gazelles.

February 14.-Stayed Duguma. This little village is close to a tributary of the Bahr Batha. On either side there is a wide belt of trees and thick growth. Here José has met again with the roan antelope(?). He finds them extremely difficult to get near. When once disturbed they are off like an arrow. They never seem to leave the thick growth for the open country. The natives here say that they are only found along the Batha and its tributaries.

In the evening the whole camp was disturbed by the news that Adamu had lost the camels. This makes the fourth time since leaving Fort Lamy, and I am really beginning to feel that I shall never reach Abechir. Though it was late, two were found, but still there was the prospect of a long hunt on the morrow for the other two.

February 15.-José left early with all the men, the Sultan and the village people. Within an hour or two one camel was found, but the other, the big one and the best of the four, was still missing. However, José picked up its spoor, and the direction of the prints showed that some one had intentionally driven it into a small Kanuri village. Of course the chief of the village professed to know nothing. At one time the spoor zigzagged backwards and forwards, then crossed and recrossed, done, of course, to confuse the pursuers, and quite contrary to how a camel would march when by 
itself. At this point the Sultan and his men were for giving up the chase, but Jose still held on, and as I have related very luckily picked up the spoor, which went this time straight for the village, again pointing to the fact that there was a driver upon his back. José arrived in late this afternoon followed by the wayward camel. I breathe again freely. This is a land where "pinching" is brought to a fine art.

February 16.-Left Duguma. The road has taken a bad direction to-day, an average of $130^{\circ}$. After fourteen miles we put up at the first Kouka village, called Fitteri, which is under the Chief of Marlikashi, where we had our mid-day "chop." This makes two days from el Birni, but I am sure there is a more direct road from that town to here than by going by Duguma. Even by the latter road I make the distance twenty-four miles. This could be done in one day. So from Seita here the distance could be made in two and a half days as the Erench march.

February 17.-Reached Abu Serafa in four hours. On the road I and Jose shot a gazelle each. This makes sixteen since leaving Fitteri. Abu Serafa is a small Kouka town at the foot of a little chain of rocky hills that overlook a flat and almost treeless expanse. Their formation is the same as the el Birni hills. At Abu Serafa we had our midday meal, and then made for el Krenek, which we reached after sunset; altogether a very tiring march, a distance of twenty-five miles.

The same evening an interesting old Mallam from Abechir came in ; he had done the journey in eight days. He was on his way to Bornu with something like sixty head of oxen, and in their place he was going to bring back horses. At his request I gave him a letter to Brocklebank at Maifoni. This also gave me the opportunity of telling 
the latter of the disappearance of Braima, whom I sent from Kusseri with photo-plates and letters. My men say that he has taken my money and then thrown away the letters and photos into the bush. If this has happened, and it looks very much like it, it is the first time in my experience that I have heard of white men's letters being held in such contempt. As a rule they are looked upon by the natives as bad "juju" which must not be touched. It is a great misfortune for me, as there were something like fifty photo-plates and films and two telegrams to be sent from Maifoni, one home and the other to O.M., saying the probable date of my return (March).* Braima is a Kanuri. As I have remarked before, these people, I think, are the most despicable under the sun. They possess no good trait, sacrificing everything to their greed of gain. It was this which made them fall into the hands of Rabeh, when in the hour of victory after Kiari had defeated his enemy, instead of setting a seal upon their success, they fell to and commenced looting the baggage, \&c., of Rabeh, who, taking advantage of their demoralisation, returned and defeated them.

Before leaving, the old Mallam gave me some dates from Abechir. They are excellent, of the eating of which there is no end! They are most nourishing and I should say invaluable for a long desert journey; one could subsist on them for several days. Besides the staying power which they possess, they are a first-rate mild medicine.

February 18.--Stayed el Krenek in the hopes of getting the Nyellitt, but Jose's repeated attempts proved unsuccessful. The game has all left this part as it is now so overrun with Arabs and their flocks.

* These fears were ill-founded; the telegrams, and, as far as we can tell, the plates and films arrived safely in England.-ED. 
February 19.-Left in the afternoon for a village on the way to Birket Fatme. Before getting there José shot three hartebeest which are nothing like any I have seen before. They are small, and the whole skin is a pale golden roan in colour. It may be the East African form, but from what I can remember the ones I shot on my last journey, near Gaba Shambi, were different. One of the three has a good head, with twenty-one inch horn measurements. I also shot a gazelle (Rufifrons) with nine and a half inch horn measurements. This gazelle is well distributed all over the country. Since leaving Fort Lamy we have shot thirty-eight of this species, two pigs, three hartebeest, and one giraffe.

The name of this town is Bedina and is Kouka. A good deal of weaving is done here. They are a good lot of people, and the old white-bearded Sultan on our arrival ran about like a three-year-old, giving orders to his men, some to fetch wood, others water, \&c. The river, which is about one and a half miles from here, is something like two hundred yards in width. It is now nothing more than a sandy bed, except that in places there are deep pools of water, still frequented by crocodiles. Though an excellent resort for the large antelope, José has failed to find it here. Just now there are too many Shuas about.

February 20.--Stayed Bedina.

February 21.-Left for Birket Fatme, which we reached in four and a half hours. This is, or rather was, a small French post, and is close to the Bahr Batha, which is here one hundred and fifty yards in width. I should say that in the rains this river would be quite navigable right up to Lake Fittri.

We are still in the land of the thorn, but in places these trees recede, forming with their red stems and branches a 
russet band in the background. Then the road passes through a shabby growth that has failed to flourish in this arid country, stunted trees, almost leafless, others half decayed, and a prey to the ravages of ants. The limbs of many of the trees have fallen and lie bleached to the colour of dead bones by many suns, and in between these living wrecks there springs a sparse bush growth.

As one journeys on, the eyes tire of this scene of desolation and seek the ground, observing every blade of fallen grass, till after a time the thorn-trees creep in again, startling the eye with their red branches filigreed with tender green, showing such vitality that one is convinced that they are the true inheritors of the soil. At rare intervals the ground here and there forms depressions that become shallow sheets of water in the rains. In these places there are groves of sturdy trees with black limbs and branches full of vigour and leaf. But beyond these girdles of green everything with the exception of the mimosa seems to wear badly, and to faint under the heat of the pitiless sun.

Towards evening Jose went across the river and brought in two hartebeest. Birket Fatme is not a large town, but I suppose it owes its prominence on the map to the fact that a post is near it. To the south-east a group of hills, about two hundred feet in height and of the same character as Abu Serafa, dominate a flat, bush-covered expanse.

They are known as the Messmeje hills, and are inhabited by a tribe of the same name.

February 22.-Birel, ten and a half miles, a small Messmeje village. This tribe is not a large one, and on first thoughts it is rather puzzling to assign a reason for the people being wedged in, so to speak, between the Bulala and Kouka. They inhabit quite a small stretch of 
country, but it is pretty well populated. It is bounded on the west by Birket Fatme, the south by the Messmeje hills, the north by the Bahr Batha, and as far as Am Haggar on the east, and from west to east a three days' journey will traverse their country. I had an interesting talk with an old Messmeje chief as regards their origin. $\mathrm{He}$ told me that they were formerly in the neighbourhood of the Bahr Salamat, until they were driven up here by the Arab razzias. Altogether they have had a stormy time, for no sooner were they free from the Arabs than they were exposed to the raids of the Abechir Sultan.* They lived on tenterhooks and never knew safety, for the Sultan's men would swoop down suddenly upon them and carry off their young people and flocks. At the present time the effects of this persecution are very plain to see in the scarcity of boys and girls, while their flocks have dwindled down to almost nothing. The nearer one gets to Abechir this becomes more and more evident. But now the old order has changed and their feeling of relief must be great. The French have been in occupation of this country for a year now. These people have a good disposition, especially the women, who are light-hearted and bave a delightfully easy manner with one. They have neat faces, with rather retrousse noses, into the right nostril of which bits of wood and imitation coral from Bornu are as a rule inserted. The hair is made into small twists, which hang down like a long fringe or curtain all round the head. The Messmeje, though possessing a different language, marry with the Kouka and Bulala.

Kiari went sick on the road to-day. I am afraid he intends to retire from these scenes of his labours. I shall miss his time-worn face.

While at Birket Fatme a caravan of Kanuri arrived. * Mahmud Mourra, who succeeded Ahmud.-Autror. 
They had come from Maidugari. With them was Brocklebank's headman, who is going to buy camels at Abechir for the Government. These Kanuri have a large store of goods with them, which they hope to sell in Abechir at a great profit; some twenty horses, a large number of Bornu gowns and also kola nut. The country people rather welcome a caravan of this kind passing through their town, as it gives them a chance of buying small needs with the food they give to the travellers; in this particular instance beads, salt, and "gabbiga" (strips of cloth), peppers, and pieces of imitation coral as nose ornaments. As soon as the caravan takes up its quarters for the night, generally under some large tree outside the town, the women come out with baskets of unground corn, and each traveller buys what he requires, the seller going back and preparing it for him.

February 23.-A long march of about twenty miles. Kiari collapsed on the road, and I had to leave him at a village on the way.

In the evening an elephant-hunter came in from Abechir. One has to hold a permit to shoot elephants, but no tax is levied.

February 24.-Passed a number of villages on the road to-day, all Messmeje, including Durban, where we stayed for the night.

February 25. - A march of two hours brought us to Am Haggar, an old deserted French post, and the last before getting to Abechir. The Bahr Batha is close by and is a good 150 yards in width. The country is now very open with low scrub.

Soon after we arrived, a headman, Batha Marjam, Sultan of the Massalit people, with twenty horsemen, came in from Abechir. He had orders from the Com- 
mandant Julien to meet me and to give me every facility on the road. So my letter has borne fruit and apparently my services have been accepted.

We had a haul of fishes this afternoon. The river now is nothing more than a sandy bed, except here and there close to the banks there are deep pools, full of fish. Quite an army of boys and men several rows deep were "driving" one of the pools. The greater number had each a large piece of wood, about two feet long and cut in the shape of a sabre, at the end of which was a large hook with a socket, and into this the point of the stick was fitted. Attached to the socket was a line. With these weapons the men as they advanced swept the bottom of the pool to and fro with one hand, much after the action of reapers with scythes, while with the other they held the lines. The commotion caused by the men walking through the water sent the fish flying and jumping in all directions, and coming within the zone of the hooks many were struck and then hauled out of the water by the lines, the hooks having detached themselves from the sticks, which were then left free for the men to use as weapons to kill the fish with. The whole thing struck one as being very skilful. Besides those who fished in this manner there were others carrying wicker baskets, round and with a hole in the bottom. These they plumped upside down in places where the water was shallow, as one does when chasing a wounded bird with one's cap. If a fish was caught the arm was put through the hole in the basket and the fish hauled out.

The people we have been amongst of late, the Kouka, Messmeje, and Massalit, are without weapons, not even a spear, which is rather a rare condition of things to find in Africa. They have been disarmed by the French, 
which does not speak in favour of their character. The only weapon they have now is a piece of wood three feet long and cut after the shape of a sabre, a form which enables them to deal cuts at their adversary's neck.

After leaving Am Haggar we struck the river again at midday, where we rested before resuming the march.

The river here was quite two hundred yards wide, and there was a good deal of thick wood on both banks. The Massalit Sultan tells me that when the rains are at their height it overflows its banks to some distance, but then the banks are very low and the gradient of the bed is hardly perceptible.

The bed is nothing but sand, which gives one the impression that this river is going to be swallowed up, the same way as the Bahr el Ghazal that used to flow into Lake Chad.

For three months in the year the river would be navigable for small launches from Fittri right up to Abechir, and there are no rocks.

The country has now lost the character of the mimosa forest; it is more open, with sparse trees and bush, all leafless. After ascending a gradual rise, a vast expanse of low tree-growth as often as not meets the eye, extending as far as the horizon, in tone a pale grey, the colour that a distant mass of bare branches always gives, except in places where belts of the thorn-tree make russet streaks, and here and there in the distance big trees of stout growth and brave with leaf show out in splotches of dark green, a welcome sight to the tired, sand-laden eyes.

For the last three or four days an old Hausa, on his way to Abechir, has been travelling with us. He has come from Kano with two loads of kola carried by a small donkey. 
$\mathrm{He}$ is a tough old man, and his sixty years seem to sit lightly upon his shoulders, though his legs are much spindled by age and trekking. All the same, he drives his donkey along manfully, making his twenty miles a day. With him is his wife and one daughter, a charming creature. The donkey is without doubt the right beast of burden for the travelling trader of slender means, such as many of these Hausas are. The present instance is a good example. The old man has for an outlay of 13s. (the price of his donkey at Kano) carried his two loads to Abechir from Kano, a distance as the crow flies of eight hundred miles. His article of trade is kola. In Bornu the price for twenty-five big nuts is one dollar, or 2s. 6d.; and fifty small ones can be bought for the same price, and 3s. is given for a hundred in Kano. I do not yet know what they sell for at Abechir, but I should fancy the old man would make a profit double the original cost.

February 28.-Going along the road to-day, an old Mallam, much bent, shuffled past me, a worn figure that one would pick out at once from other wayfarers. TWhite hairs of sparse growth bearded his face, and his eyes were dim. Through age his toga, of native cloth, was the colour of hemp and full of holes as if moths had fretted it for years. His only weapons of defence were two wooden staves; one of these he carried over his shoulder, and from it were hung two grass-woven baskets containing all his worldly belongings. Over his other shoulder was slung a wooden board written all over with texts from the Koran, and much polished with hand-grease. Round his right wrist was wound his string of prayingbeads. Altogether a figure of holy but not pinched poverty.

I have met with these travelling Mallams before. 
They are, so to speak, the missionaries of the Mahommedan faith, and go from one village to another to teach the young children, and in return for their holy labours they are given food and lodging.

Yesterday José shot a Senegal hartebeest. It is rather surprising to find this species and the other one, of which I have already spoken, almost together. The latter, I think, is worth getting. Since leaving Birket Fatme the game-bag has been one hartebeest and six gazelle.

At Am Haggar the Messmeje people came to an end, and we entered the country of the Massalit, another small tribe. Then up to the Kachemere hills we passed villages belonging to the Apsari, Dadjo, and Bakka, all separate tribes, or rather bits of tribes, jumbled together and living side by side. Though they speak different dialects, they all have the Arab tongue in common. This conglomeration of people is confusing, and in most cases it is well-nigh impossible to find out where they originally came from, for they show a profound ignorance about their origin. Among the Messmeje, Apsari, Dadjo, and Bakka I can find no separate characteristic to make them distinct. They all distinctly possess the negroid type of face, large heads with prominent foreheads, broad noses with splayed nostrils, and fairly thick lips. In my own mind I have no doubt that they have been pushed up to these parts from the regions of the Salamat by the Arabs. It is quite possible even that their ancestors were the slaves of the Arabs, who gradually freed themselves and worked to the north (where they are now) and set up communities of their own, the people of each being known by the name of the founder-for example, Dadjo or Bakka, or a man belonging to Dadjo or 
Bakka-and in time from small communities these different peoples have grown to the proportions of tribes.

Their villages are small and compact; each hut is in a compound made of zana matting, and under these circumstances one does not see much of the women, who sit within the compounds as they spin their cotton. All round the village at close intervals are rough trestles, and upon them round bins of zana matting, in which is kept the "gero" in heads during the dry season, but by the time the rains come on it is thrashed into grain and stored in gigantic mud jars, some of which are five or six feet in height, and really very graceful in form, and all made by the women.

March 1.-José left in front of me so as to get into Abechir before me and find quarters. We are now close to the Kachemere range, or rather group of small hills, which run in a south to east direction, and lie about one and a half miles to the right of the road. The highest peak would not be more than three hundred feet. The hills are of stone of a predominant reddish hue and bare but for a little grass and scattered stunted trees. In formation they are small, isolated hills, or groups which at some points from a distance have the appearance of being one continuous range, but as one moves along their forms rapidly alter and get disconnected, which makes mapping them on a road sketch no easy task.

Almost running parallel to these hills is the Kondongo range, which lies on the left of the road and at some distance from it. They have much the same form and character as the Kachemere.

From these ranges onward to Abechir the country is 


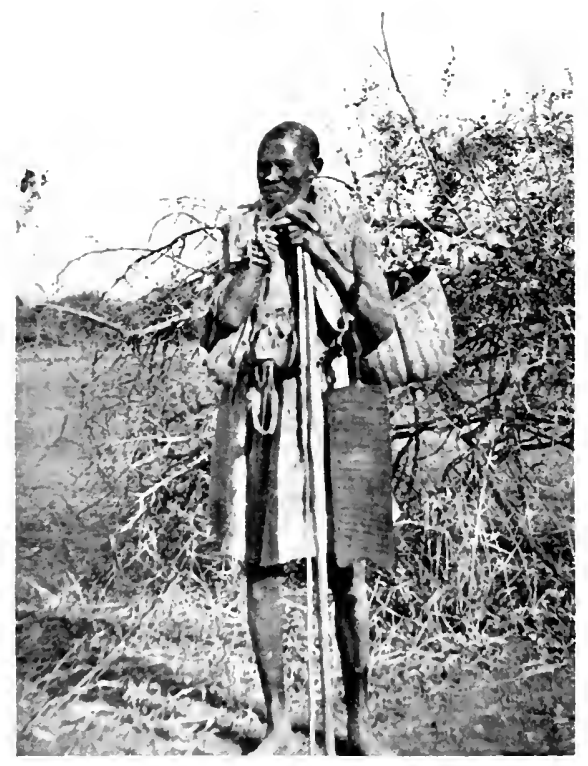

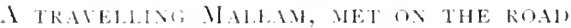
TO AliecHIK.

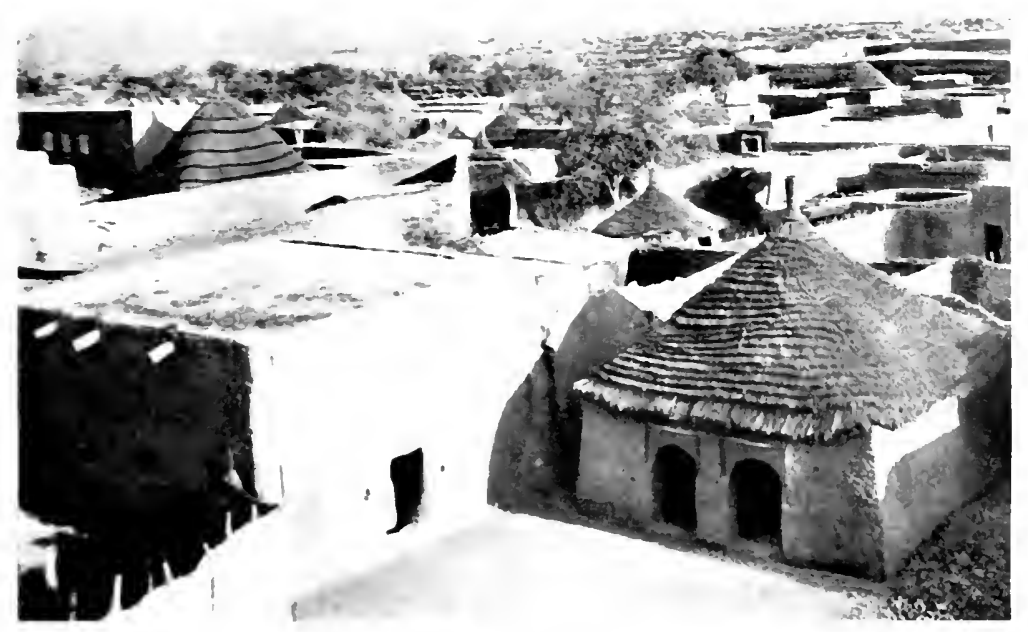

I IIEII HF IHERHR. 

thickly populated with Wadai; there are many large and compact towns.

An incident occurred to-day which demonstrated well the character of the Wadai people. I have not yet observed any good point about them; they are treacherous, quarrelsome, and sulky. A guide, whom I had taken from a village on the road, while I was observing angles to some hill peaks, went off the road into the bush, as I thought on account of some necessity. As he did not return after several minutes a Massalit man, belonging to the Sultan who had come to meet me, who was with me as well as my own orderly, Mamadu, went back to call the guide. $\mathrm{He}$ found him crouching behind a small bush, and the next moment the Massalit man came running back to me with a terrible knife wound in his left arm; the whole of the biceps muscles were rent and were hanging out.

The Wadai are famous, or rather infamous, for the use of the knife, which they carry strapped to the left arm.

To have a murderous assault like this committed almost under one's eyes is astounding, and only shows what the real attitude is of the Wadai towards the white man. As far as possible the French have disarmed every man, and Abechir now is practically knifeless.

As soon as I reached the village where my men had stayed to await me, about an hour ahead, I attended to the injured man and sewed up his wound. Then I returned with several of my men and those of the Massalit Sultan to the village from which I had taken the murderous guide, with the object of capturing him or, failing him, the chief of the village. Of course, 
when I got there, the man was not to be found, so I took the chief and brought him with me to the village where I was going to stay for the night. This action had the desired effect, for the culprit was brought in during the night. This is the only course to pursue in a case of this kind; take the chief, and invariably the men of the village will give up the culprit in order to free their chief.

We have said goodbye to every stick of wood and are now travelling over very open country, with low, weedy growth, and here and there a Euphorbia plant, while the vicinity of villages is marked by irregular, burnt, straw-coloured patches of the standing grainstalks, from which the heads have been cropped. Everywhere the Karangia grass grows rampant, a hateful weed with prickly seeds that are a pest to the feet. The head is something like a pipe-cleaner to look at. When ripe, the row of seeds, each a spiky ball, detaches itself and falls to the ground, where it becomes a sore trouble to the feet of man and beast. To take a dog with one on trek is to inflict much pain and grief. The spikes of the seed get between the pads, and if not extracted often cause inflammation. Bornu is also full of it. When I was at Maifoni in 1904, I was told that the prison, then a mud-built structure, had the foundations of its walls trenched round, and the trenches filled with Karangia, which proved most effective against any attempts at escape prisoners might make by burrowing under the walls from the inside.

March 2.-A long march of twenty-three miles brought us after sunset into a large village (Argoutie), which is about three hours from Abechir. Soon after our arrival, José came in from Abechir. He had got there 
yesterday evening, a march of something like forty-four miles in the day-not a bad performance! He found that the Sultan had already prepared quarters for us near the palace. He brought with him a gazelle that he had shot on the way out. This makes a total of forty-five altogether since leaving Fort Lamy.

March 3.-The last day of the long trek from Fort Lamy. Soon our eyes will rest upon the longed-for sight of Abechir, and the last phase but one of the expedition will be finished! Two of my men, Dogo and Alan-na-Gudu, for weeks past have had their heads shaved, with the exception of a patch at the back and a narrow band across the crown from ear to ear. The latter represents Abechir and the former Omdurman, and as each place is reached the patch or strip of hair will be shaved off, with much the same idea as when we used as boys at school to tick off the weary days of the term.

About five miles from Abechir one becomes aware that the plain directly to the front is gradually rising to a low ridge, not more than 1,500 yards long. It has crept out of the plain from one's left front and terminates on the right in a cone-shaped kopje which is about one hundred feet in height.

A hope springs up that Abechir will be seen lying in the plain on the other side, but on gaining this little ridge there is nothing to be seen except the ground gradually shelving, to rise again gently to another ridge that is similar to the first, but lower if anything, and at a distance of about three miles. The approach of any one from this quarter can be signalled from this ridge to Abechir, which lies another two miles to the front.

The first sight of Abechir, so renowned in geographical 
history, is very disappointing; perhaps because one has been led to expect so much. The eyes search almost in vain for some definite outline to compass the extent of the town. The sandy colouring of the mud houses and walls, toning in so completely with the surroundings of the town, is probably the reason why it is so inconspicuous. The only building that stands out distinctly enough to attract the eye is the palace, a substantial building of brick, dark in tone, and reminding one in shape and size, but without the battlemented roof, of the Tower of London.

Half a mile from the town one of the Sultan's chiefs met me with a number of horse and escorted me to my quarters near the palace. I then went straight up to the barracks, which lie a little way off and to the east of the town, the fort itself being well placed on a low eminence of rock.

The Commandant, Julien, a man of stout proportions and of a rough manner, made anything but a favourable impression upon me. The offer I had made of putting myself and my expedition at his disposal to assist the French in their present difficulties was dismissed in a few curt words, and not a word of thanks! He then went on to say he could not take the responsibility of allowing me to pass by the road to el Fachir, although Colonel Moll in a communication had given me permission to do so. It is true that the Massalit affair had not taken place at the time of his writing it, but the Mourrah road, which goes almost due east from here, is practically safe. I think he looks upon me as a secret agent, much the same as Colonel Pulteney was considered when he followed at the heels of Marchand, with whom Julien served, and I expect those experiences have embittered him against the English. Anyway I have run up against the wrong man. 


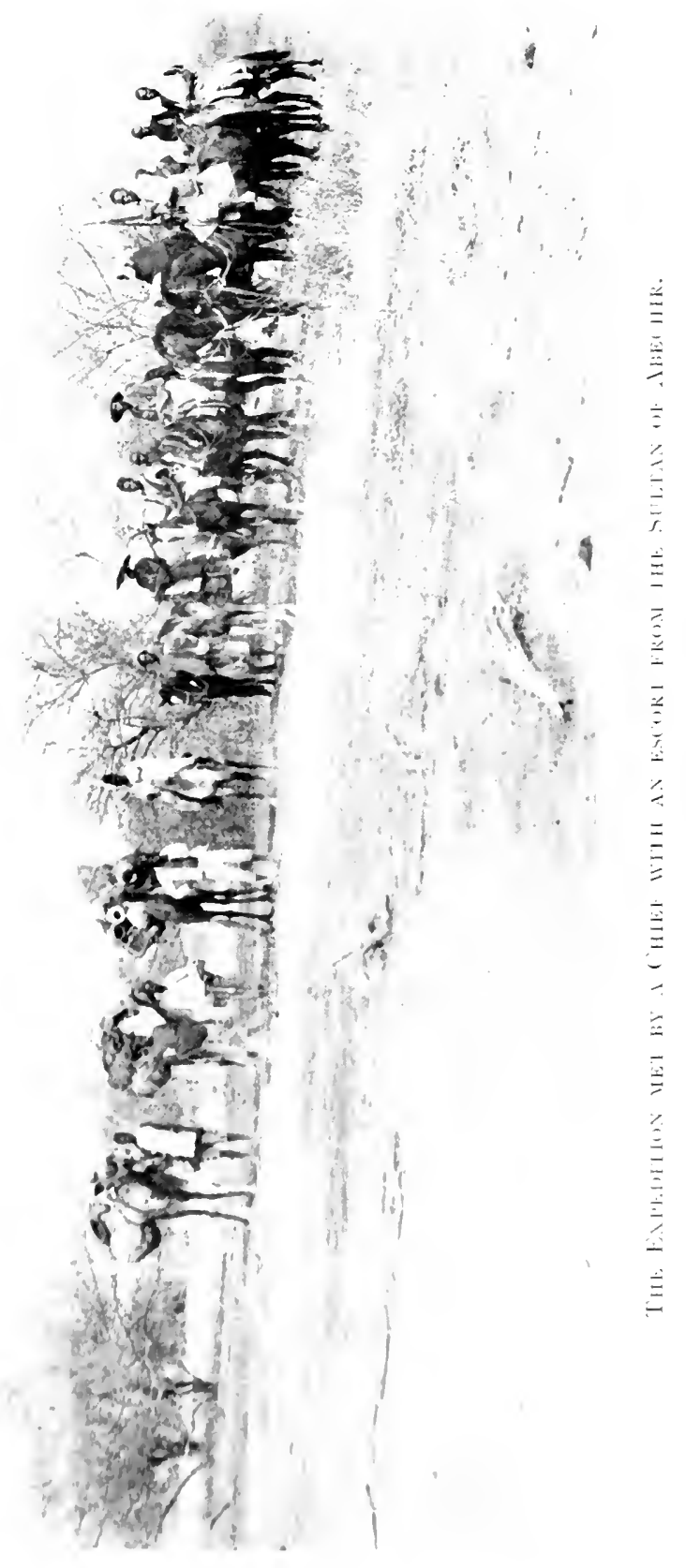



The French have not a leg to stand upon as regards the Massalit affair. They were attacking a Darfur chief who was under Ali Dinar. Julien excused it by saying that Captain Fiegenschuh went into that country without orders. My arrival here is anything but pleasant to the French, who, I firmly believe, were making preparations for a punitive expedition; in fact, there is hardly any doubt about it, but my presence here has knocked everything on the head.

The Sultan has had orders to return the camels which the French had collected for their transport to the various villages in the neighbourhood.

The history of the whole affair is as follows :-

Before Captain Fiegenschuh, who was commanding the French force, had got into Abechir, the big men of the town sent out to him assurances that they would not oppose his entry, adding also that the Massalit king was ready to come under the new Sultan Assil, whom Fiegenschuh was bringing up with him. Here I must explain that Assil is the half-brother of Doude Mourrah, with whom he had quarrelled in 1903. Leaving Abechir with the object of seeking a refuge in Bornu, he was captured on his way down, near Bukero, by the French, who made him a prisoner and exiled him to Brazzaville. In 1905 I met him near Fort Crample; he was then on his way to Fort Lamy, the French having the idea of keeping him at hand as they intended to make him Sultan as soon as they had taken Abechir.

After the occupation of Abechir by the French, Commandant Brisset was in command, but he left in December and his place was taken by Fiegenschuh, who, it seems, left Abechir shortly after to visit the Massalit Sultan, Hadjar Din, with the idea of pilfering his allegiance from the Sultan of Darfur. He took with him a strong 
force of 2 lieutenants, 2 sergeants, with 150 soldiers, and 200 irregulars armed with rifles from the Sultan Assil. On approaching the Massalit town he found that the Sultan had already made quarters for him and his men near the road outside the town. Deceived by this show of friendship, he remained in them and sent forward his interpreter to tell the king to come and see him, but the king refused, saying that it would be better if Fiegenschuh were to come in, and he assured him of his friendship. Accordingly Fiegenschuh left, but before he reached the town his force was surrounded by men who came rushing in from either side, yelling and brandishing their spears. Thinking their behaviour only a form of welcome, he shouted back to his men not to take up their arms, and he then proceeded on his way to the king, whose men surrounded and killed him. At the same time the whole of his force was massacred, with the exception of nine of the Sultan's men and twelve soldiers, who succeeded in escaping back to Abechir.

I have heard since that some of the soldiers are prisoners and are tied up. There are plenty of widows about; many have come to the place where we are living, and all want to marry my "boys."

The Massalit Sultan is a powerful king, and though himself a Mahommedan, many of his people are not, and they are reputed to be cannibals. They are black.

The Sultan, Assil, tells me that the Massalit king wants neither to be under el Fachir nor Abechir. At the present moment (March 7th) Assil has a number of his men on the border.

The occupation of Abechir was carried out with hardly any bloodshed. The fight at the small stream, Wady Choc, which is distant a day from the town, was a small affair, the Sultan's men, although he was there in person, 
making a small stand. The greater number of " big men " refused to fight, and sent messages to this effect to the French, saying that they wanted Assil as their Sultan, since Doude Mourrah had treated them badly. From Wady Choc the Sultan retired to Abechir, got his things together, and made ready for flight, although the next morning he made a show of resistance at the first ridge, two miles from the town. But he soon cleared off, and when the French entered Abechir they found it deserted. The large number of killed and wounded given to me at Fort Lamy (official) is entirely erroneous. The Sultan fled to the north. As Abechir lies in an open plain, it seems extraordinary why the French allowed him to get away. The whole town was given over to loot by the soldiers. The traders-Tripoli merchants-bitterly complain of the way in which they were treated. They stayed in the town, thinking that they would be safe, but all their things were taken from them, and in many cases they were tied up by the soldiers. The soldiers ransacked the Sultan's houses of everything, and all the documents relating to the history of the town were destroyed. There were many valuable records, several relating to Nachtigal and Vogel, and one in the former's handwriting. In my eyes nothing can excuse this vandalism. Apparently everything except the dollars were treated with indifference.

At the present time there is no money in Abechir. The Kanuri caravan which we met at Fittri can sell nothing, and the old man with the kola is hanging on in the hope of better days.

Abechir wanted the English; in fact, they were ready to pay a tribute to our Government, and at the time of the arrival of the French were, I am told, in communication with Ali Dinar. It is wonderful to see how the 
English name is respected here. In their simple minds the people still cling to the hope that the English will take the country. The fact that Nachtigal left papers here written in English makes them think that we have the first claim to the country. It is possible, too, that Nachtigal posed as an Englishman, else how could the natives have got hold of this fact? I have mapped the road up to this place, and this they say is preparatory to our coming here! I am treated with the greatest deference. Every morning people who have been to Khartoum and know our rule come and pay their respects to me. If it had not been for the bad character of Mahmoudu Mourrah and the oppression he put upon his people, which caused them to fall away in their allegiance, the French would not have had such an easy entrance into Abechir.

The Wadai people are notorious for their drinking habits. Their drink is a beer made from the "gero" and "dawa" (Hausa, "Gear"). It takes two days to brew, and has the colour of tea. When bottled it effervesces to a certain extent. I occasionally drink it when I know where it is made. The "big men" make a better quality, flavouring it with dates and pepper; the latter, they believe, makes it less intoxicating. There are many drinking dens in the town. The drinkers sit in a circle, and one man presides over the large jar which contains the beer, and passes round a small calabash to each in turn. This quaffing goes on without intermission for hours together, and it often happens that quarrels ensue and knives are freely used. In Mourrah's reign Abechir was a very drunken city, and every excess was perpetrated, the drinking bouts of the "big men" frequently ending in wanton slaughter. As like as not, a passer-by in the street would be caught and plied with beer to amuse the 
company, and afterwards his throat would be cut and his body thrown to the dogs.

March 4.-The Commandant has conceded a point. If I can get an assurance of help through Darfur from Ali Dinar at el Fachir, he will allow me to go. It will take a good month before I can get an answer from Ali Dinar. A quick runner can reach el Fachir, or Darfur as it is known here, in sixteen days by the Mourrah road, which goes almost due east from here. I am getting the head Mallam of the Sultan to write the letter, saying that I am English, and asking his protection through to el Fachir. And I have also stated the present I shall bring with me (£100, a gun and a horse).

March 6.-A Fulah, who has been to el Fachir before, has volunteered to go, and I am sending Mamadu with him, giving a pound between them for the expenses of the road. Mamadu showed me the things he had bought in the market for his needs on the road, and they certainly struck me as a funny little lot: a bunch of artificial coral for one dollar, six strings of large blue beads for the same, a box of matches, a little salt, some blue dye, and a roll or two of native paper.

Last night, as a last hope, I wrote the following letter to the Commandant :-

"Cher Colonel Julien,-Mon courier part demain, et je vous écris pour demander encore s'il serait possible que vous changeriez votre idée et permettriez moi de partir d'ici sous ma propre responsibilité par la route Mourah dans cinq ou six jours. Je gagnerais le temps et l'argent, et je voudrais bien revenir chez moi vers Mai pour voir mon frère, qui part en Juin avec le Capitain Scott pour le Pole Sud.

“Je crains que je vous donne beaucoup de peine," \&c. 
I received no answer.

On the day of our arrival here we found that comfortable quarters had been prepared for us by the Sultan close to the palace. To our surprise, a Sara boy, whom we had met at Archambault, was told off to attend upon us. He is the body-servant of the Sultan, and when not with him is always here. $\mathrm{He}$ is useful, too, as we get first news from him of all that happens. He is a bright fellow, always laughing and dancing, and picturesque withal in his matted hair.

In the afternoon I and José went to pay our respects to the Sultan. The entrance tower, through which one passes into the precincts where his dwelling-houses are, is an imposing structure, some sixty feet in height. During his stay here Nachtigal must have passed through many times; in fact, every morning to "salaam" the Sultan. After emerging from the tower we crossed a spacious court and then threaded our way through various antechambers, well built and quite twenty feet in height, and connected one with the other by small courtyards. In one we passed retainers awaiting orders; in another headmen, with their followers, expecting audience; in another groups of household boys standing by ready to distribute the mid-day meals to the various retainers. At length we reached a cul-de-sac, from which several doorways led straight into the dwellings of the Sultan, who appeared at one of them after a few moments to greet us. We were not quite strangers, for we had met before at a village close to Fort Crampel when he was on his way down to Fort Lamy from Brazzaville. He is a tall, spare man of six foot, with a much-receding forehead but refined features, and a small moustache and thin fringe of beard. His manner is quiet, and he gives one the impression of a man wishing only to live in peace 


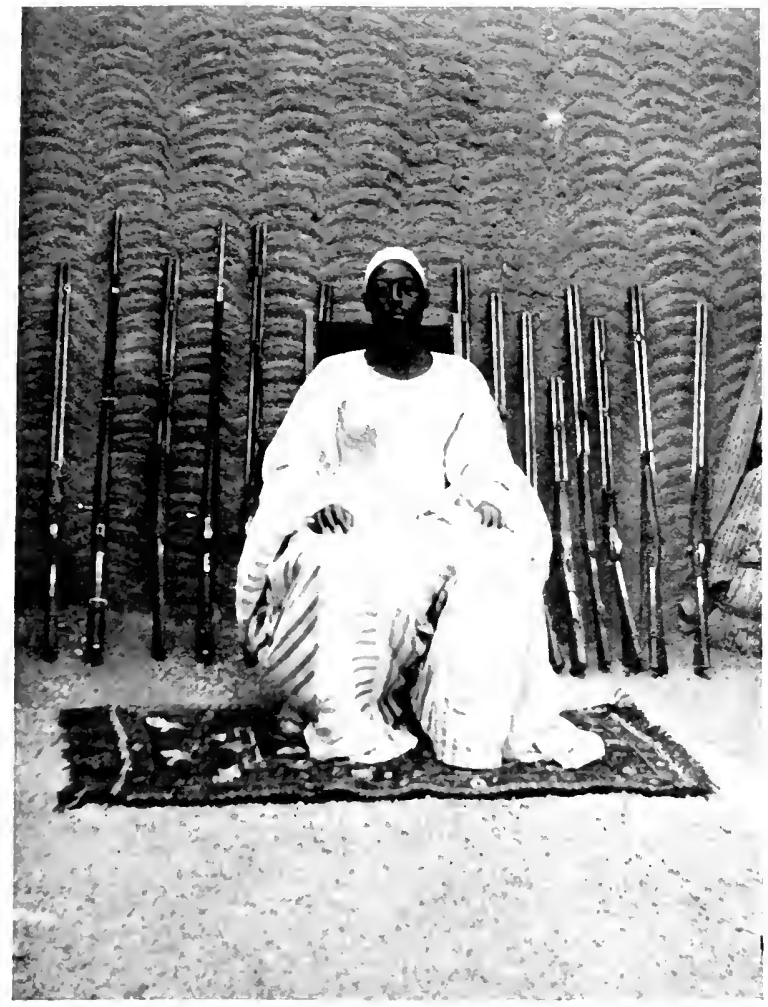

Arsll, Suldax af AbroHIk.

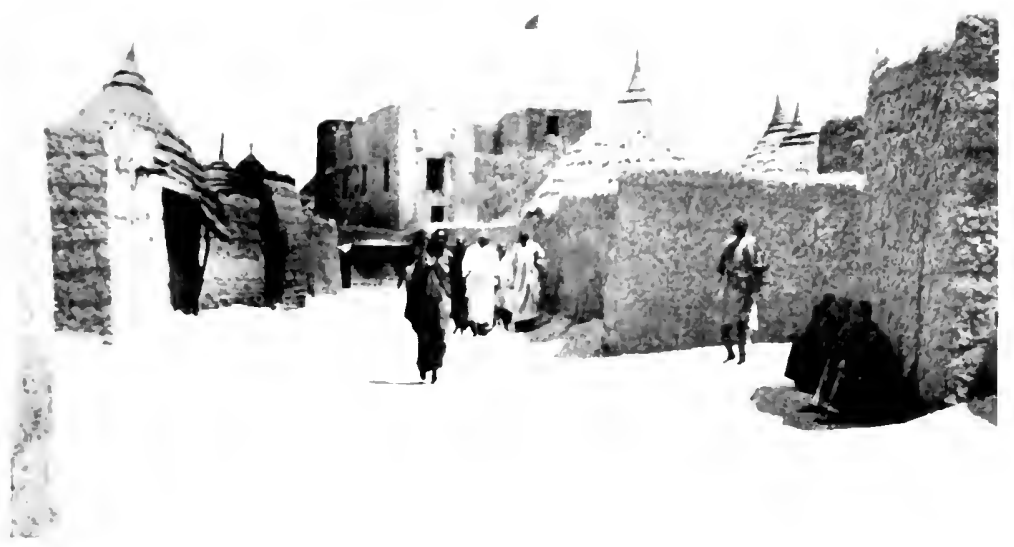

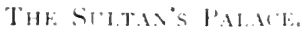



with his subjects and not to be bothered by the troubles that a man of stronger character might bring upon himself.

$\mathrm{He}$ welcomed us warmly, expressing his great desire to treat us well, so that we could give a good account of him "to the great English people farther east." Every morning he sends us a basket of "chop"; one day it is pigeon flavoured with pepper and dressed with alkama; another day it is fowl or game, done in the same way.

The second impression one gets of Abechir dispels the first to a great extent, and one comes to realise that it is really a big town, and one that goes back in history. At the present time it is not enclosed by a wall, although nearly every habitation, consisting of one or more mud buildings, together with thatched huts, is walled in, while those belonging to the rich men are practically forts in themselves. The heart of the town, occupying about half of the whole area, has a substantial wall about fifteen feet in height; in fact, this wall marks the extent of the original Abechir that was built by the Sultan Cherif. But since those days the town has increased and buildings have sprung up on every side. Now this enclosed part of the original town is almost entirely covered by the houses of the Sultan and by those of his retainers. A street, known as el Fachir, leading from the western to the eastern gate, cuts it in two, and about half-way, going towards the east, the big entrance building that leads into the precincts of the palace confronts one on the right hand. From an architectural point of view it is difficult to place it. It has a flat, whiteplastered front, about ninety feet in length and eighteen feet in height, castellated and two-storied, with four windows. The eastern end of the building is higher and forms the tower. On the right hand of the entrance 
there is a square, turreted stairway, which leads to the upper rooms and the roof. There is nothing attractive about these three rooms, which lead from one into the other. The walls are plain stucco and have many recesses. Branching off at right angles from the west end there is a low wing consisting of one large, rectangular room, divided into three parts by plain Gothic arches, and upon the plastered surface of these there are rough attempts at square and diamond-shaped patterns in coloured chalks, but they are all left half finished.

In the foundations of the tower itself there are several deep dungeons, quite as dreadful as any in the Tower of London. Many cruelties have been perpetrated in them, especially in the reign of Doude Mourrah, when refractory slaves were immured, some for months at a time, in total darkness, till they grew tame or died from their sufferings, while others were heavily chained and ironed into painful postures until they were starved to death.

The whole building is of brick, now in a state of dilapidation, for the plaster has fallen away in many places, exposing the brickwork to view. The bricks, which are fire-burnt, are large but narrow, and in some parts of the foundations rough stones have been used.

The structure was begun by the Sultan Cherif, and finished in the reign of Ali. Men from Cairo (Massa) built it, and for their labour took back with them much money and valuable ivory.

It retires a little from the el Fachir street, and from each end a mud wall ruus out at right angles to the front, forming a quadrangle. Here, every morning, chiefs with scores of men are packed together, waiting to pay their respects to the Sultan.

The three principal streets in the town are: the 
Wady Choc, which runs in a north-easterly direction from opposite the market (this is the road one would take for the Tripoli route); the el Fachir street, which runs from the west to the east gate through the Sultan's enclosure, or rather citadel of the town, and practically cutting it in halves; and, lastly, the Am Siogo street, running in an east-by-north direction and gained by the eastern gate. Of the three this is the most important street, where the chief trade of the town is carried on among the Tripoli merchants, who live in the highwalled mud houses with entrances of rough-hewn planks bounding each side of the street. The market really begins where the narrow lane debouches into an open space formed by the houses retiring from the alignment of the road. From this point onwards down the street, from eight o'clock in the morning till late in the afternoon, all the trading element of Abechir comes together. Arabs and men from far-off Tripoli, whose paleness of skin and character of dress distinguish them from the rest of the market-sellers, squat in a row along the walls with their goods laid out in front of them. The bigger. men dispose of their merchandise within the houses. Then, where the street begins to close in again, rows of women, sometimes two deep, line one side with their baskets in front of them, containing various kinds of native food in small quantities. As the street comes to an end, picturesque groups of hills in the distant background stand out against a bright blue sky.

The big market is outside the palace walls. It can only be called big from the point of view of numbers and not as regards the produce that is for sale. There are no stalls like the markets have in Bornu, and the women sit in groups of twos and threes, all huddled together in the full glare of the sun. The Bornu cloth is much worn 
here, which lends to the aspect of the crowd a prevailing note of dark blue. There is nothing on sale but country produce, mostly food-stuffs, which are brought in calabashes, in small quantities to suit the needs of the poor man. It is a mixed lot of goods, but each trade is grouped together as a rule. In one corner the meatsellers are to be seen with the meat, which is generally cut up in small pieces, placed on straw-woven mats before them. But there are some bigger lots, such as the sides and legs of animals, and these are strung to upright poles. In another part are the sellers of firewood and dry fodder for the horses. The former is brought to the market from a great distance on the backs of donkeys.

Among the food-stuffs are sold several sorts of seeds and vegetables that are used for making soup. Of seeds, for example, I noticed the following: Kabua (Hausa), Duraba (Arabic), Kowal (Arabic), Betarrk (Arabic) or Reedi (Hausa), much cultivated by the Munchi, a whitish seed like that of the water-melon. Then there is another, a small black seed known as Sumsum (Arabic) and Karrkasic (Hausa), and the dried leaves of a vegetable called Karkangi (Arabic) and Yakwa (Hausa).

Other foods are: wafers of "gero" called Kisseri (Arabic) and Tewa (Hausa), Alkama or Gummi (Arabic), peppercorns, called Siegett (Arabic); tomatoes, onions, and an excellent turnip called Figgel (Arabic). It grows to some size and is like a carrot in shape. It was originally brought from Egypt by the old historian, Mahamud Bamba, on his return from Necca. There are two kinds of salt; the better kind is in rocks of a pale pink colour; the other, which is white, is really a kind of potash. Other products are camel-butter, ground-nuts, and grains, such as " gero," "dawa," and " maywa," which is 
like " gero," but ripening later, and much grown in Bornu and but little in Wadai.

There are several kinds of scent to be found in the market. One is a berry, about the size and colour of a cranberry, and called Dillkie (Arabic), Ajajerri (Hausa). It is mixed with butter and then rubbed into the skin. It has a cleansing effect as well. Another is Summuk, which is a gum from the mimosa, or Tewlalli (Hausa). Then there is a reddish wood, which is ground to powder and used on the head. The women of Bornu favour it a good deal. Another wood is called Nukkeri (Arabic).

At one end of the big approach to the palace is the cattle market; not much of one to speak of, since there is no cattle in the country, for there is nothing to feed them on. At the present time a bullock sells at from eight to ten dollars, a cow fourteen, a big sheep one and a half to two, and a donkey six or seven.

No, Wadai can boast of little except its beer and the use of the knife!

Abechir is wonderfully situated in a natural arena. In whatever direction one scans the horizon, groups of hills of reddish stone, some with sharp peaks that look as if they had been cut out of cardboard, meet the eyes at intervals. In the centre of this great arena the town is built on a slight elevation formed between the two little streams of Wady Schau and Am Kammel, the former flowing past the north end of the town, the latter by the south, both finding their way eventually into the Wady Choc. They rise in the hills near Mourrah to the east.

'The sandy plain all round has the appearance of ground that has been reclaimed from the sea. It is scattered with stunted Euphorbia, and a compact plant, called Dielon by the Hausas and Māhĕt by the Arabs, which has stiff, oval leaves of bluish green and berries that grow 
in thick clusters, which are eaten by the natives. It is scarce in Bornu but plentiful in Dermerghrum.

The plain is treeless, but there are some ill-grown trees in the town itself, which afford no shade but from a distance give the place an appearance of being well off in this respect. Abechir can boast of only one fine tree, that by reason of its size and solitary position is a good landmark. It stands not far from the town and close to the Fezzan road.

March 9.-A strong reconnaissance of five officers and 115 men left for the direction of the north to-day.

March 11.-A caravan of fifteen camels came in from Benghazi to-day. The chief merchandise was clothstuffs of various kinds, and scents, cones of sugar, and tea. These Arabs had been three months on the road, which they describe as being bad. In places one has to go eight to ten days without water, and six days without food for camels.

Here the palmy days of the caravan are over. Before the French occupation a trader would arrive with a hundred camels at a time, and everything was very much cheaper. In those days a dollar would buy a cone of sugar, that now costs double that price. Of course, too, there was a great trade in slaves and guns, but now that has been put down. There were no caravans in the rains, but in the dry season there was one arriving every month. And the number of Tripoli traders, which used to be between 200 and 250 , is now reduced to 60 or 70 .

March 13.-For the last four days there have been strong, cold winds from the north-east at night, invariably causing harmattan effects during the morning.

The white camel died this morning. My number is now reduced to two. Camels seem to be most delicate 
animals; no sooner do they fall sick than they are ready to give up the ghost at once. The wastage in camel flesh on active service must be enormous. There is no food fit for them in this neighbourhood. I am giving my remaining two to the Sultan to look after, and they will feed with his own camels at some distance from here.

March 17.-Serious news has come in. A large force from Ali Dinar is within a day of the town. They have burnt several towns belonging to Mourrah, Mareb for one. My two men have been taken prisoners; but it is reported that my letter has been sent forward to Ali Dinar.

The Commandant has given me the following information. The enemy's force left el Fachir on the 12th of February and on March 8th occupied Nyeri, the capital of Tama, reinstating Othman as Sultan of that place. Previously this man was driven away by the French, who made Hassan Sultan in his place. Then the latter in his turn was driven away by the Massalit after the disaster to the French arms. In the reign of Ali Tama paid tribute to Wadai, but not since that time.

The force is commanded by Adem Roudjal, Commander-in-Chief, and under him Adem Ali, Mahmoud Ali Bardingayé, Ali-el-Senoussi, and Ibrahim Harsun, cousin of Ali Dinar. The strength of this force is computed at 2,500 rifles, of which two-thirds are rapid; 200 horsemen (Furian), 800 horsemen (Arabs, Tama, \&c.), commanded by Badjisuri Kamkolak, Adri Echenay, and several others who were faithful to Doude Mourrah and became refugees at el Fachir after the occupation of Abechir by the French.

On the 15th of March 800 horsemen burnt villages to the north-east, fifteen kilometres from Mourrah, killing men and seizing women, children, and cattle, after which they retired to Tama. 
March 18.-Last night five chiefs of the Sultan left to join Ali Dinar's force; they took with them one of the Sultan's show horses and over 200 rifles.

There is a great deal of unrest here. The majority of the people would like to see the old régime back, as it was in the days of Doude Mourrah, although he perpetrated cruelties, for they had a free hand and could raid when they liked.

The following are the names of the five chiefs: Abdallah, Abukka, Barrka Bedirr, Shaihi, and Annay. With the exception of the last, who is Wadai, the others are all slaves, Arabs originally from the Bedirr country, except Shaihi, who is Sara. Besides these, three of the "big men" in Mourrah have joined el Fachir.

Raids upon Wadai by Darfur are not unknown in the past. In the reign of Cherif there was a big one on much the same scale as the present.

It is said that the latter has been brought about by the disaffected chiefs tempting the raiders by their reports on the large amount of cattle and other plunder to be had.

March 18.-After lengthy discussions, the king in the afternoon sent off a picked force of his most trustworthy inen to try and come up with the renegades and persuade them to return. The Sara boy goes with them. This is a blow to us, as he has looked after our wants very well.

March 20.-We have finished with the harmattan; it has become very much hotter, and the sky is very blue, without any haze.

March 21.-Have sent off Jollolo to-day to Maidugari with forty-two photo films and a letter to Brocklebank, asking him, should he think it necessary, to cable in code home a résumé of the information the Commandant gave me. The latter expressed a wish that I should send a cable. 
I suppose that if Darfur has really raided Wadai it means we shall have to give compensation. Jollolo is to return here with $£ 25$, for my funds are getting low, and I cannot tell how long I shall be here.

Towards evening the king's men returned without coming up with the runaways. They had had orders not to enter Nyeri.

March 22.-Several Al Hadji arrived from Mecca to-day by the Da Sila road. These journeys on the average have taken from three to four years. They have not many good words for Ali Dinar, but the last man I questioned said that the Sultan used to be bad, but that now he had mended his ways.

Rumour is rife that an Egyptian force is advancing against el Fachir, and Zubeir's name is frequently mentioned.

The following are the principal towns on the road from Da Sila to el Fachir, which they report is a good one, with plenty of water and food.

From here to Da Sila is six days. Then come Gusabayda, Ustarayna, Kuku, Gusamerie, Dourie, Gimayza, Azumm, Marmarie, Simyar, Marginnie, Amayram, Binduss, Diebiss, Kayla, Bir Tir Weel.

The Al Hadji took twenty-two to twenty-five days to complete this distance, but I think it could be done in eighteen days.

Through the aid of the Sultan I have unearthed the historian of the town, one Mahamud Bamba. $\mathrm{He}$ is a Kanuri, and came here in the reign of Harrifen. $\mathrm{He}$ went to Mecca with the Sultan Cherif, and on his way back visited Stamboul when Mahamud Hania was Sultan, and for some time after that was a soldier. At the present time he must certainly be quite ninety years old, but he himself claims to be over a hundred. His memory 
is wonderful. He was an intimate friend of Nachtigal's, who used often to sit and drink coffee with the old historian while he listened to him relating stories of his city and people.

Although bent with age now, he must have been a big man in his younger years. Even now everything about him is big in form. His heavy features are negroid in appearance, a pug-nose like indiarubber and much splayed out at the nostrils, and thick lips. His hands are big and bony, and the left never leaves his praying-beads, which are extra large on account of his rheumy eyes. His forehead is lined with deep furrows, the result, I should say, of much recounting. His white moustache and little beard are almost hair-bare, and his shiny head is in the same condition. When the morning is cold he comes to me in a capacious reach-me-down coat of leather, much after the style of a beater's coat, and overalls to match, and both are worn ruddy with age. He has a cheery heart that seems to be foretold in his light and almost springy step, as with bent back he hastens forward to shake one by the hand. After that he settles himself down upon his mat with many "Dear, oh dears !"

Old as he is, he has method in the recounting of his facts. In answer to a question he will sprawl out his bony hand to smooth the gravel; then with the forefinger he will make strokes as he proceeds to record the various names or points in his story. And then, the tale finished, the bony fingers will sprawl out once more to smooth over the surface of the ground just as one rubs figures from a slate.

\section{Note on the Origin of the Wadai People.}

They claim to have come from Mecca originally, but I am much more inclined to think it was from somewhere 
in the region of Darfur. They were led by King Abdul Kerim, who founded Wara, a day's march to the north of Abechir, and there the Wadai dynasty was begun. After the death of Abdul Kerim the next Sultan was Sarbun, whose reign began about 1770 , and lasted for thirty-three years. Under his rule there was great peace, and the herds increased, and there was much prosperity, and no molestation at the hands of the Arabs. Probably to escape from persecution was the original cause of their migration westwards.

On the death of Sarbun, Harrifen, one of his three sons, succeeded him as Sultan. The other two were named Darrad and Dahawieya. Harrifen is the first Sultan that my informant, Mahamud Bamba, can remember. His reign lasted for fifteen years, and he appears to have gained popularity with his subjects by drawing upon the prosperity of his father's reign. He was generous and gave away great presents; he played and feasted, and meat could be had by any one for the asking. In those days a Kano gown would fetch twelve cows in the market, which is an indication of the great prosperity of the herds.

Here the Diary ends, or rather stops, for it is clear that there was more to come when the writer sat down to make one of those little histories of which he was so fond.

We see that there had been no thought in his mind for some time of going forward on his journey, and so the unworthy rumour that he lost his life in an attempt to escape from his detention at Abechir by employing a ruse is here shown to be utterly false.

It was only natural, seeing the shuffling that was 
going on upon the border, that the French should regard him as a spy at first, or even worse, a fate-sent accuser, for his arrival at Abechir was nothing less than a marvellous historical coincidence.

But as we read on we can see how his transparent honesty was steadily breaking down all prejudice. Then in the crisis of war the moment comes which he believes to be his for action. In no reckless spirit, but with full knowledge of the great danger he is running, yet believing in the power of his name as an Englishman, he presses forward unarmed to interpose himself between the Furians and the French and persuade Ali Dinar to refrain from joining in the war against the white man.

We have seen by how little he failed!

Loud as was the voice of natural sympathy that went up to mourn a brave man's death, the patriot's deed still waits a word of thanks. It might almost seem to us as if my brother had gone under a cloud to his death. 


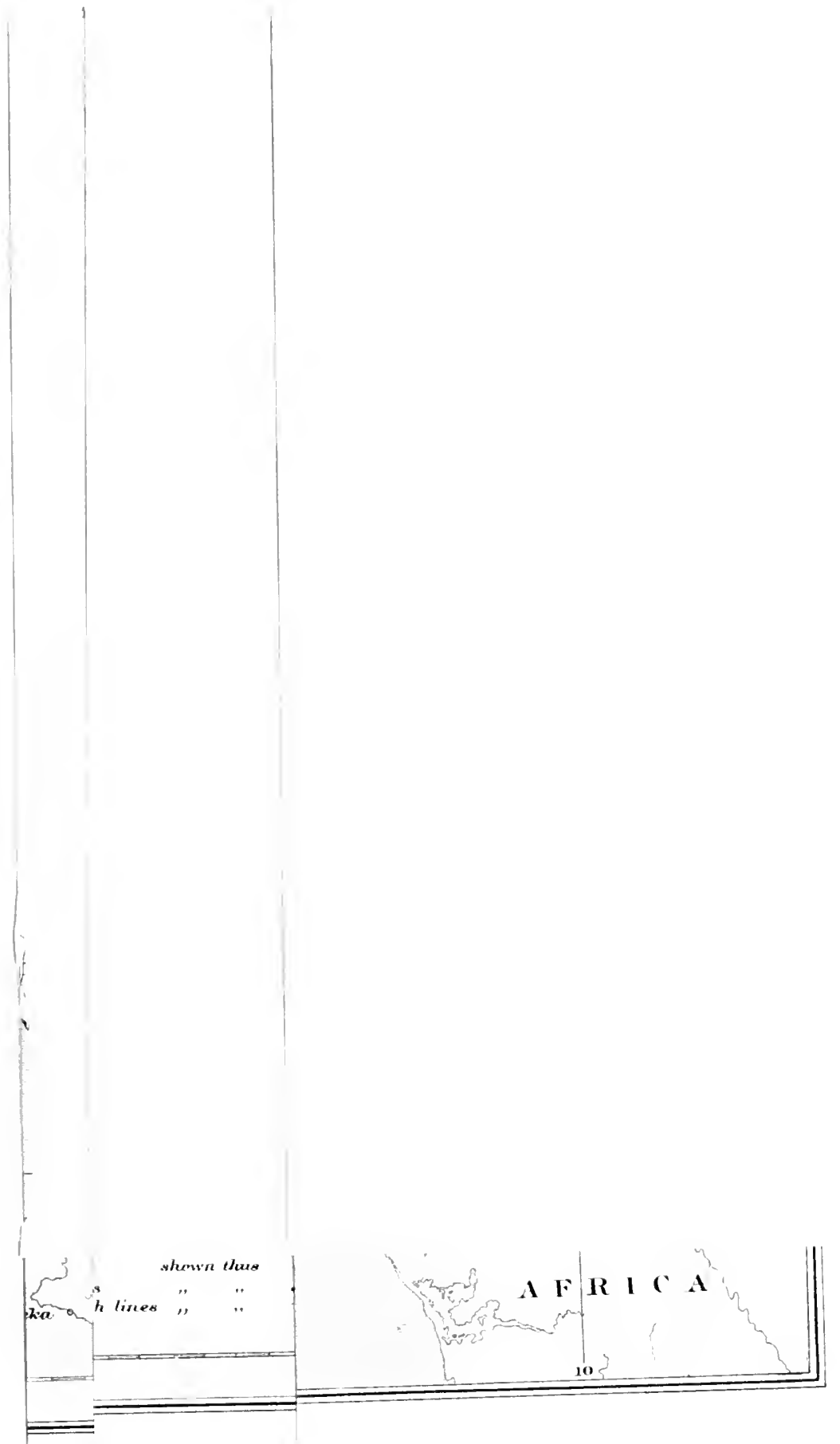




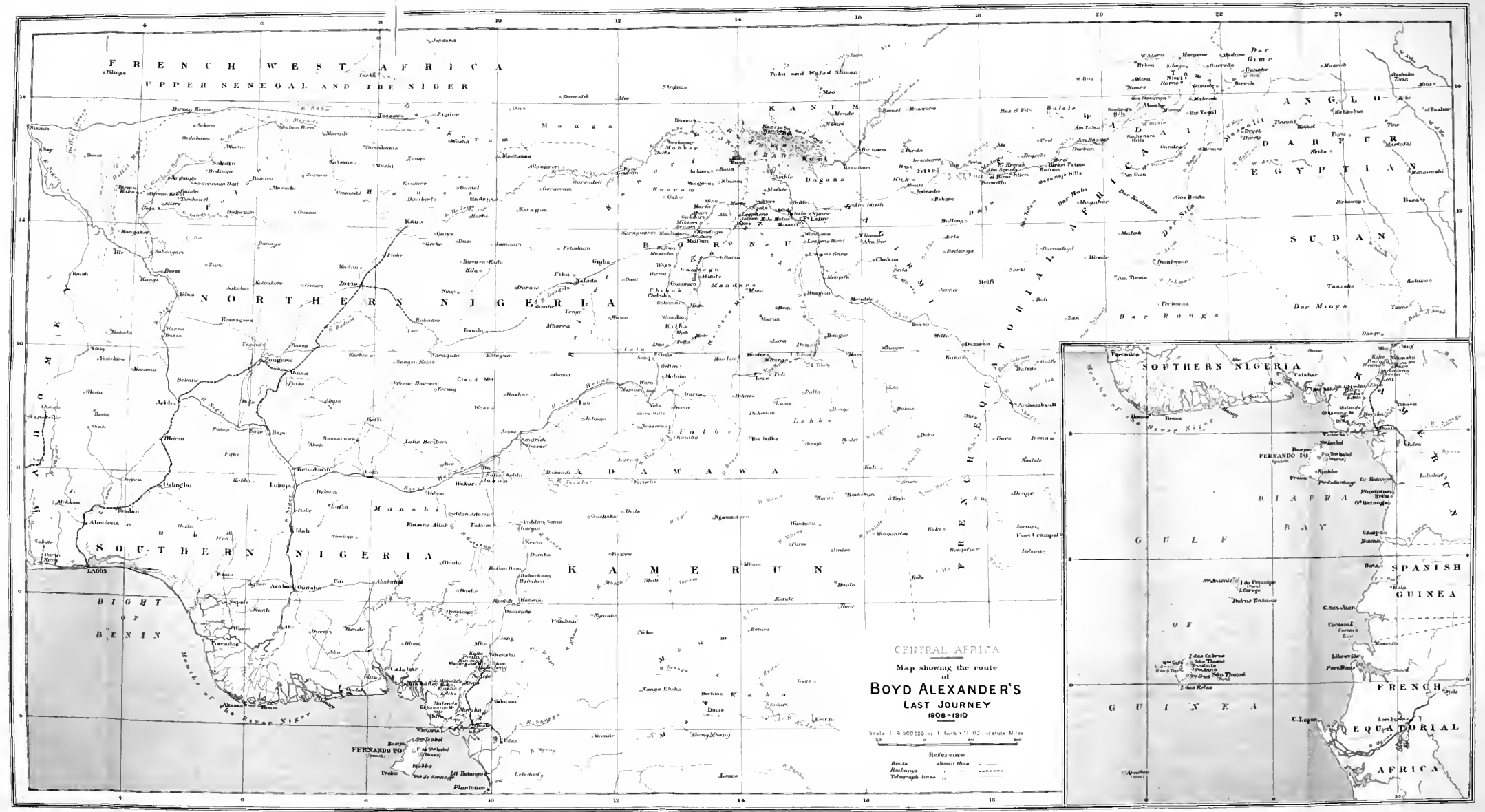




\section{INDEX}

Abarr, 198

Abatchi, misdemeanours of, 244-6

Abbagowada, wells at, 241

Abdul Kerim, founder of Abechir dynasty, 287

Abechir, 249, 260, 269, 270, 273, 276, 277, 279, 284; French occupation of , 230-2, 248-9, 272-3 ; journey to, 48-9, 232 et seq.

Abrio, M., 91

Abu Idielli, forest near, 238

Adamawa, Fulani, settlement of, 159

Adametza, Commandant, 133, 135

Adamu, or Mordibo, 159, 160 et seq.

Adwa tree, uses of, 221,232

Afade, 2:1-2

African birds, Boyd Alexander's be. quest of, to British Museum, 59

Agurin, Adamu at, 160

Ala, Kanuri town, 199

Albanell, Padre, 68

Alexander, - 275

Alexander, Claud, of Ballochmyle, 5,7

Alexander, Lieut.-Colonel Boyd Francis, $5,6,14$

Alexander, Dr., Maifoni, 177

Alexander, Herbert, 177

Alexander, Captain Claud, 32-6, 44, $54,144,145,176-8$

Alexander, Mrs. B. F., 6-7, 36

Alexander, Robert, twin of Boyd, 8 et seq.

Alexander, Sir Claud, of Ballochmyle, 5

Alexander, Wilhelmina, Burns's verses on, $5,6,7$

Ali Dinar, Sultan of Darfur, 44, 49, $222,230,275,283,285$

Ambas Island, 69

Ambatch, uses of, 73, 215

Am Haggar, 261-3

Am Kammel stream, 281

Angola natives in the Cocoa Islands, $77-8$
Animal sacrifice of the Bakwiri, 11011

Annobon, visit to, $68,81,84-8$

Antelopes, Nyellit, seen, 252, sought, 257,258 ; Roan, 255

Arabic, spoken by older Bulala, 250

Arbari, on the So people, 218-19

Argoutie, 268-9

Ashimi, Shehu of Kukawa, defeated by Rabeh, 187-8

Assan, Sultan of the Bulala, at Yao, 250-1

Assil, Sultan of Wadai, 48, 50, 271, $272,276-7,281$

Athi, 248

Axim, 75

\section{Babenkr, 13j}

Babirr, Rabeh's captain, 187

Babukon, 136

Bafum-bum, 136-7

Bahr Batha, aftluent of Lake Fittri, $250,252,258,263$; navigability of, 263 ; tributary of, 255

Bakka people, 265-6

Bakwiri race, animal sacrifice among, $110-11$; dirty habits of, 100,110 ; towns of, 113,114

Balama, Munshi village, 143

Ba Ligna River, 234

Ballochmyle, association of, with Burns, 5,6

Bambui, natives, market and houses at, 134-5

Bamenda, journey from to Ibi, 132 et seq.

Bamilikie tribe, at D'san, 132

Barclay, - Resident, Yola, 152, 162 ; death of, 163

Bare, 129

Barth, - , on the Kanuri, 180

Basel Mission, Kamerun, 113

Bashima tribe, 160

Batanga fishermen, 72-3

Bates, career of, 73 
Batta pagans, 160

Bautchi, Necca pilgrims from, 246

Bead currency, Kusseri, 229

Bedina, 258

Beecroft, Commander, monument to, 67

Beer, Wadaian, 274-5, 281

Béhagle's monument, 201, 203

Benghazi, caravan from, 282

Bere Bere, Hausa name for Kanuri, 184

Bere Bere, town, 172

bi Fadio, Emir, 160

Bird notes, last journey, 69, 73-4, 217$18,235,254$

Birds, collections of, by Boyd Alexander, 16 et passim; in San Thomé, $82,83,86,92-3$

Birket Fateme, 258-9

Birni, former Kanuri capital, 181-3 ; ruins of, 181, 182

Birth customs, Cameroon (Ninong), 125

Blindness, at Konduga, 196

Blue dye made near Mussoba, 173

Bobo Amadu, late Emir of Yola, 153, 154,161 et seq.

Body staining at Bambui, 134

Bongor, canoe transport to, 229

Booth, Major, of Geidam, 185

Bornu, agriculture in, 172, 184, 193, 199 ; cloth of, $279-80$; horses of, 209 ; Rabeh at, 185 et seq. ; races in, 181, 183, 197; Shehu of, see Garuba

Borrero, or Bush-Fulani, 164-5, 237 ; colour of, 159

Boyle, -, Assistant Resident, Yola, 152,158

Braima, and the photographs, 226, 257

Bricks, Kanuri-made, 182-3

Brigandage, Verre tribe, 152-3

Brissot, Commandant, 226, 248, 271

British administration in Yola region, 162 ; desired at Abechir, 273-7

Brocklebank, - , at Maifoni, 176, 177, $178-9,194.256-7,261$

Brulé, Lientenant, 225

Buduma of Lake Chad, origin of tradition on, 182

Buea, 70, 100-1, 120; earthquake shocks near, 109-10, 113-14; journey from, 120 et seq.

Buffalo, 128-9, 137

Bukar Kargu, Kachella, 173

Bulaia people, 240, 246, 250

Bulala town, 239-41

Bullock teams, Brocklebank's, 179
Burns, Robert, 5, 6

Bush, 217, 219, 221-3, 23t

Bush-Fulani, 159, 164-5

Camras, Ilma das, 75

Cairene builders, Abechir, 278

Calabar, in 1909, Boyd Alexander on, 65-7

Camels, purchase of, 149, 185, 217, $228,234,242-3,255-6,282-3$

Cameroons (see also Victoria), cocoa plantations in, 120 ; mountains of, 70,72

Camping, methods of Boyd Alexander, 199-200; ver'sus house dwelling, 91-2 ; visitors, welcome and other, 200

Canoes, Buduma and Kotoko, 182

Cape Coast Castle, 75

Cape Verde Islands, Boyd Alexander's expedition to, 28-9; labourers from, on Prince's Island, 96

Caravans, palmy days of, over, 282

Carriole Peak, Principe, 94

Cattle, 164, 220, 281

Chameleons, 200

Chauk, fight at, 229, 231

Chauvelot, Captain, Boyd Alexander's diary found by, 52, 225

Cherif, Sultan of Darfur, 284, 285

Chibuk people, aspect, 171; dwellings, 170 ; funerals, 170 ; languages, 171 ; tribal marks, 171 ; truculence, $166-7,170$

Chibuk hills and road, 166-7, 170, 172

Chinchingi, 143

Clemen, Herr, 79

Coast towns, W. Africa, 75

Cocoa cultivation, $83,97,126$

Cocoa Islands, bird-collections in, 31, $44,69,82,83,86,92-3$

Communications, see Road-making

Compactum camp bed, 246

Compagnie Ouhame et de la Nana, $150-1$; prices of, 229

Congo forest animals, Boyd Alexander's passage on, cited, 27

Cotton-spinning and weaving, Logomane, 212

Cow-Fulani, 160

Cow trade, Cameroon, 130-1

Cowrie currency, Bambui, 134-5

Crater Lakes (Eddip), near Ninong, 126

Crocodile Pool, Wukari, 144 and $n$

Crocodiles, Bahr Batha (river), 258

Cuckoo, Boyd Alexander's passage on, cited, 26-7

Currency, 134-5, 153, 198, 229, 241 
Customs, Portuguese and German, 76, $89-91,98,100$

Dahatwieta, of Abechir, 287

Dallwa, 173 et seq.

Dalziel, Dr., Yola, 152

Dances, 170, 175-6

Darfur, political problem of, 43

Darjeeling, 7

Dar Massalit, 247, 249

Darrad, of Wadai, 287

Dar Sila, 285

Dates from Abechir, 257

Dear, Charles, painter, 39

Death and burial customs: Bakwiri, 110-11, Batta, 157 ; Cameroon, 124 ; Chibuk, 170; Fulani, 153; Munshi, 143 ; Verre, 153

De Baba, adventures of, 222

Desert dunes, 191

Diaries of Boyd Alexander, 58-9 ; given to Miss MacLeod, 48, 53, 60

Dielon plant, 281-2

Dikoa, 192 et seq., 200, 201-3, 205-7, 210-24, 227, 251; German rule at, 200,205 et seq.; horses of, 209 ; Rabeh's headquarters, $185 n, 189-90$

Disarmed tribes, IVadai, 262-3

Dix, - , police officer, Yola, 152

Djanabara, Bulala town, 246, 249

Dog Peak, San Thomé, 84

Dollars as currency, 158 and $n, 162-3$, 229,241

Donga River, rapirls on, 138

Doroté, battle of, $225 n$

Doude Mourra, ex-Sultan of Wadai, and the disturbances due to, 48-9, $27 \mathrm{l}, 273,274,276,278,288$

Duala, trade, \&c., of , 71-2

Dubabe, game near, 222

Duisburg, Lient. von, Resident, Dikoa, 205, 207

Duke Town, Lagos, 65

Dum palm, 2.42

Dumas, M., 150

Dumba, 137

Duncan, Capt. J., Boyd Alexander's expedition with, 28-9

Durban, Musso Majie village, 261

Durrant, Mr., 75-6

Dwellings: Marragi, 169; Munshi, 143 ; Shua, 236

Djsentery at Annobon, 88

Dwyer, second in command, Yola, 152

Emon natives, 65

Ediki, 121, 123

Ekunolelu, Bakwiri village, 113, 116, 119 el Birni, Middogo town, 253-5

Elephant grass, 72

Elephant-shooting fees and permits, 261

Elephants, 215; ferocious, 129

el Fachir, Boyd Alexander's objective in last journey, $44,226,270$

el Krenek, 256-7

Ellis,-, police officer, Ibi, 145, 146

Elphinstone, O. V., Resident, Ibi, 145

English, French, and German methods in Africa, 71, 128, 140-1, 152, 153, $168,227,228,239$

Etam, 123

Eurema, the, of Yola, 158-9

Expeditions : First, with Capt. J. Duncan to Cape Verde Islands, 28-9; second, "Cape to Cairo" with Major Gibbons, 29; third, from Gambaga to Accra Coast, 30 ; fourth, to Fernando Po, 31; fifth, Alexander-Gosling, "From the Niger to the Nile," aims, course, and success of, 32 et seq. ; last, course of, from Abechir to death of Boyd Alexander, 48 et seq. ; Boyd Alexander's diary of, 63 et seq.

Face-hIDING by women of Shehu of Dikoa, 209

Faderella, Rabeh's son, 187, 201, 203-4, 228

Fagan, C. E., 22

Fan tribe, locale of, 74

Fea, - , thrush found by, on Principe, 97

Fernando Po, Boyd Alexander's expeditions to, 31, 67-9, 98

Fiegenschuh, Captain, 229, 231 ; and the Massalit, 247-8, 271-2

Field Imprisonment, No. 1, 245-6

Fishing at Am Haggar, 261

Fitteri, Kouka village, 256

Flowers, scarcity of, in Africa, 223-4

Food-stuffs at Abechir, 280

Football, at Muyuka, 121

Fort Crampel, 271, 276

Fort Lamy, 226-7, 228, 233, 234; letter to, 224-5; visit to, 232 et seq.; diaries given at, to Miss MacLeod, 48, 68

Fosberry, IV., Provincial Commissioner, Calabar, 65

Fox, Captain, Calabar, 67

Francolin, of Miissacke Cameroons, 107-8, 111

French (see Abechir, Fort Lamy, \&c.) apture of Wadai, 177; colonial 
methods, 228, 239; defeat by, of Rabeh, $185 n$ et seq. ; leave to travel in Chad territory accorded, 48, withdrawn, 49 ; military operations in Wadai, Moll on, 229 et seq.; Massalit affair, 247-9

"From the Niger to the Nile," 33 et seq., 37-9; cited, 19-20, 26-7, 73 n

Fulani, (see also Bush anl Cow do.), $159,161-2,181-2$

Furian raid on French territory, Boyd Alexander's investigation of, 49 ; upshot of, 50-1 ; death of Boyd Alexander, 52

Gajıro, swifts at, 211

Gallwui, new puppy adopted at, 217

Gambaga, Boyd Alexander's expedition from, 30

Gambaru Piver, 215-16

Game, sce under" names

"Gari," 195 and $n$

Garuba, Shehu of Borna, 251 and $n$; and his brother, 205, 207

Garuba, Kukawa (Kanuri), 133

Gazelles, 211, 213, 215, 217, 219, 221, $244,255,258$; red-fronted, 234,258

"Gear" drink, Wadai, 274

Geese, Gambaru River, 217

Gellen, tsetse belt near, 163-4

Gentil, $185 n$

Geri, 163

German, French, and English methods in Africa, $71,128,132,140-1,152$, $153,168,227,228,239$

German Sudan, 251

Giajola, M., 150

Gibbons, Major, Boyd Alexander's expedition with, 29

Giddan Adamu, 142-3

Giddan Sama, 138-40

Gimeta, village, Yola, 151, 152

Giraffes, 224, 252, 258

Girrni, Bere Bere town, 172

Glossina palpalis, on Prince's Island, $95-6$

Gokombi, 170

Gold Coast, Boyd Alexander's birdcollections from, 29-30

Gold Coast Constabulary, Boyd Alexander's service in, 29

Gordon, General C. G., Boyd Alexander's hero-worship of, 18,45

Gosling, Captain G. B., 34, 35, 54, 165

Grant, Ogilvie, and Boyd Alexander, 22,30

Ground pigeon, San Thomé, 83

Gubduri, Shua town, 197
Gubigi, 215

Guinea-fowl, 233

Guinea-pigeons, in camps, 200

Guinea-worm, 126-7

Gulfei, tribute paid by, to Germany, 228

Gumsura, 172

Gurin, 160

Hadjar Dis, Massalit, Sultan, and Fiegenschuh, 271-7

Hairdressing : Bulala, 240 ; Kanembu, 181 ; Kanuri, 176, 181 ; Kurio, 181 ; Kwoyam, 181 ; Middogo, 253; Mobbur, 181 ; Shua, 219-20 ; Tubu, 181

Ham, transport to, 229

Hammond, Sergeant, at Pella, 165, 166

Hansen Crater, 119 et provi, 120

Hansen, Herr, Acting Governor, Buea, 100-1, 120

Harmattan, causes and consequences of, $67,71,190-1,198,241$

Harrifen, Sultan of Wadai, 287

Hartebeest (see also Senegal Hartebeest), 222 ; new kind, 258,265

Hassan, Sultan of Tama, 283

Hastings, Warren, 7

Hausas, courtesy, 138; language, $141-2$; as porters, $76-7,104$; as travellers, 246 ; wrestling by, 174; where met, $133,137,138,147$

Hazley, school life at, 14, 15

Head-shaving as calendar, 269

Helmets, Dikoa, 206

Hewby, W. P., 177, 180

Hiatu, conflict of, with Faderella, 203-4

Hitchens, - , on palm oil and kernel yield, Calabar, 66

Hobbies, value of, to dwellers in Africa, 179

Holme, -, local Assistant Resident, Ibi, $145-6$

Holst, Mr., 150

Horses, 196, 209

Howa, Rabeh's daughter, 203-4

Hurdas, Mr., San Thomé, 91

IBI, improvements at, $145-7$

llois, The, 30 ; Boyd Alexander's writings in, 24, 29, 31

Ido, 139

Ilarné, death at, of Boyd Alezander, $51-2$

Immeda, troubles at, 243

Infantry, native, Dikoa, 207

Iron, 162 ; as currency, 153

Isaac, Mr., Fernando Po, 99 
$J_{\text {ABBA, Kilba village, } 167}$

Jang, 129, 131-2

Jappa, chief of Vanga Malabu, 156-8

Jetferies, Richard, writings of, Boyd Alexander's appreciation of, 24-5

Jigi Amadu, ex-king of Malabu, 156

Jollolo, sent to Maidugari, 28t-5

Jones, Sir Alfred, 82, 83

Ju-ju palaver at Pella, 165-6

Jukon, at Wukari, 144

Jukun, king of Takum, 141

Julien, Commandant, at Abechir, 284 ; Boyd Alexander's services offered to 252,270 ; relations with, 270-1; El Fachir, 275

Kachemere hills, 265-6

Kakami, Kachella, 192 et seq.

Kalamulue, 222; tsetse belt near, 223

Kanem, as Alsatia, 249

Kanembu race, 181, 183

Kannidi, "big king " of the So, towns subject to, 219

Kano, camels from, 149

Kano gown, exchange value of, 287

Kanuri people, 176, 179-84; language of, 171 ; as porters, 196-199, 242, $214,245,257$

Karangia grass, 268

Kebbi, River, transport limit at, 229

Kent and Sussex, birds of, Boyd Alexander's study of, 23

Kentu, Hausa rubber collectors at, 137

Kestler, Mr., photographs by, of the eruption of Cameroon Mountain, 118

Keulemans, on Grey Parrots of Principe, 92

Khartoum via Darfur, final objective of Boyd Alexander's last journey, 44 ; route selected, 224

Kiari, of Kukawa, 187-9, 257

Kiari, the camel, 242, 260, 261

Kilba pagans, 164, 166, 167, 170

King, Messrs., at Duala, 71

Kingsley, Mary, ascent by, of Cameroon Peak, 106

Kirchoff, Frau, 100, 101

Knives, Wadaian readiness with, 267, 281

Knox, Captain, Maifoni, 176, 177

Kob, McAllister's, 129

Kola trade, W. Africa, 161, 261, 263-4, 273

Kondongo hills, 266-7

Konduga, Bere Bere town, 193, 196-8

Kotoko people, giant ancestors of, 213, $214,218-19,222$; of Afade, tribal marks of, 222
Kotoko-Shua, settled habits of, 237

Kouka people, 258, 262 ; villages of, 256

Krebige, 150-1, 227

Kribi, 72,74

Kuda, 217, 218

Irukawa, vicissitudes of, 182, 186 et seq., 191

Kuko, 128

Kumassi, relief of, Boyd Alexander's ornithological zeal during, 29-30

Kumba, Crater Lake at, 121

Kupé Mountain, 129

Kurio race, 181

Kusseri, German fort, history of, and journey to, 210 et seq., 223,224 , 227-8; Sultan of, 228 ; tribute paid by, 228 ; tsetse belt near, 232

Kiwojam race, 181

LAgonostictA, rare, on Prince's Island, 95

Lake, the, in Annobon, 87

Lake Amelia, San Thomé, 79

Lake Chad, attractions of, for Boyd Alexander, 20; a record year for water in, 215

Lake Fittri, affluents of, and overflows, 250 ; birds at, 247

Laminu, Kanembu Mallam, 181-2

Lamy, Major, death of, 185 1, 223, 226,228

Languages: Arabic, 250; Hausa, 141-2; Kanuri, 171, 222; Kilba, 170 ; Marragi, 169-70; Middogo, 253

Lankester, Sir Ray, 22

Leopard, of Cameroon, McAllister on, 129

Lere, transport to, 229

Liste, Dr., Kusseri, 227

"Living on the country" as practised by Boyd Alexander, 211-12 and $n$

Lobb, Dr., Ibi, 145

Logomane, 211-12

Logone River, 227; navigation limit on, 229

Loot, Rabeh's rules on, 187

Lopez, José, 29,31, 63 n 1 et passim; Boyd Alexander's bequest to, 39 ; a tribute to, 34

Lowal, successor of Adamu, 160

Lucas, Mr., Monte Café, 77

Lumpa, 128

McAllister, A, on game in Manenguba region, 129-30

McClintock, Major, 185 
Machena, bricks at, $183 n$

MacLeod, Miss Olive (Mrs. Charles Temple), her journey to Boyd Alexander's grave, 40-2, 45, 47-8, 53

Madness, ju-ju cure (?) for, 165-6

Mahamud Bamba, 285-7

Mahamud or Doude Mourra, Sultan of Abechir, 260

Mahomedu Iya, present Emir of Yola, 163

Maidugari, 191-2; an execution at, 194-5

Maifoni, Boyd Alexander's burial at, 47 , 53; Miss MacLeod's visit to, 47 et provi; grave of C. Alexander at, 55, 64, 177-8; and others, 177

Maifoni, fort at, 163-76 ; Boyd Alezander's stay at and near, 176-8; journey from, $193 \mathrm{et} \mathrm{seq}$.

“Maifoni," pupps, 217

Maillard, Commandant, and Captain Facon, and Boyd Alexander's last days and diaries, 40

Maio, River, 168-9; tsetse belt along, $163-4$

Malinde, forest near, 121

Mallams, met with, 256-7, 264

Mama N'yebbi, Rabeh's son, 187

Mandara, tribute of, 228

Manenguba Range, 70 ; villages at foot of, $124 \mathrm{et}$ seq.

Nangrove swamps, Calabar Piver, 65, 71

Marchand, Captain, 270

Marfa, 198

Marin, Mr., British Consul, San Thomé, 91

Marragi pagans, 169-70

Marriage customs, Munshi, 143 ; Verre, 153

Narte, 198, 199, 200-1

Märtens, Herr, 102, 107, 112, 117

Nassalit Arabs or tribe, 262, 265, 267; Colonel Moll killed by, in battle, $225 n$; reported cannibalism of, 272

Massé, meaning of, 234,250

Matriarchy, Verre tribe, 153

Mbo, 128, 130, 131

Necca pilgrims, 246

Mendie porters, trouble with, 76,104 , $127,137,146,150$

Menzel, Mr., 133

Messmeje hills, and tribe, 259, 260

Meurato hills, 281

Middogo hills, 253

Niddogo people, 252-3

Mier Crater, Cameroon Mountains, 120
Niguel, Don, 68

Miktari, Shua town, 197

Nimosa woods, 223, 233, 234, 242

Mina, 198

Mobbur race, 181

"Nokes" and Mecca, 246

Moll, Colonel, and Boyd Alexander, $48,224-5,270$; on French operations in Wadai, 229 et seq.; death of, $225 n$

Mondolen Island, 69

Monte Café, roça San Thomé, 76-8

Mordibu Adamu, sons of, 161

Morrough, Captain McCarthy, and Garuba of Dikoa, 251 and $n$

Nount Alouette, Cameroons, 72

Muambong, 125

Munshi race, 143, 145

Musa, Kilba village, 170

Musa, Shehu of Kusseri, 224, 228

Wïssacke, bird-collecting at, 103, 105

Mussakowa or Mussowa, soil for, 250 ; fields of, 199 ; cookies of, 212

Mussoba, King of, meeting with, 173

Mustapha, flight of, 241

Muyuka, 121

Nwato, near, 239-41

Myili, Kilba village, 167

Nachtigal, traces of, at Abechir, 273 et seq.

Napoleon I., Boyd Alexander's herowor'ship of $18,19,22$

Natural History, Boyd Alexander's devotion to, 18; see also Ornitho. $\log y$

Neild, - 185

New Year's Day at Njaire, 233

N'gala, 210; dyeing at, 214; pottery at, 213,218

Ngombo, 124

N'gornu, elephant damare at, 215

Ngosi, 123-4

Nicknames of native soldiers for Boyd Alexander, 31

Niger Company, 146, 158, 161, 162

Night's rest, amenities of, 238,246

Ninong, Cameroon, people of, 124-5

Njaire, New Year at, 233

Njo Piver, tribes along, 181

Nyellit antelope, 252, 257, 258

Nyeri, Boyd Alexander's messenger seized at, 49, 50; Sultan of, 50, 51, 283

Orapi, secured by Boyd Alezander, 32,35

Orangulma, 221 
Ornaments, Chibuk, 170-1; Marragi, 169

Ostriches, 246-7

Othman, Sultan of Dar Tama, and the death of Boyd Alexander, 50, 51, 283

Overweg, burial-place of, at Maifoni, 53

Owl, rare, San Thomé, 83

Ox blood in brick-making, 183

"Padres," Cocoa Islands, Boyd Alexander's tributes to, 68, 86, 88

Palm oil and kernel exports, Calabar, 66,72

Papagaio River, Prince's Island, 91, 93

Papagaio, Peak of, 94

Parrot, Grey, on Prince's Island, 92-3

Pay, rates of, German and English, IV. Africa, 127-8

Pella, Burri ju-ju palaver at, 165-6 ; Sergeant Hammond at, 165, 166

"Pickles," see Alexander, Captain Claud

Pipes as trade goods, IV. Africa, 126

Plantation, a station, 72

Poala, 126, 127

Poisoning white men, 239

Pony, Tubu, 209

Porters (see Hausa, Kanuri, Mendie), gambling of, 146

Potatoes, 131

Prince's Island, Boyd Alexander at, 88, 89 ct seq.

Prison life, native attitude to, 66

Pulteney, Colonel, 270

"Pumpkin and Co.," 12-13

RABEH, history and exploits of $182,185 n, 189,190,221-2,228$, 257 ; death of, $185 \mathrm{n}, 201,223$

Radley, Boyd Alexander at, 16, 21

Rafin Solder, 145

Rafines, meaning of, 215 and $n$

Ramm, - , Norfolk taxidermist, 29

Panola, Padre, 69

Rest-houses, ruinous, 172

Rice, wild, porridge of, 211

Ridicule, native dislike of, 246

Road-making, Cameroon or Kamerun, 122-3; need of, in Ibi, 152-3, 168; Portuguese skill in, 97

Roan antelope, 255

Robbers, hung, at Maidugari, 194-5

Roberts, Field-Marshal Earl, and the Alexander-Gosling Expedition, 35

Rodger, Sir John, 64

Route-maps of Boyd Alexander's last journey, loss of, 60
Rubber, story on, $147-9$ and $n$

Rum trade, Duala, 72

Sevadra, Don Diego, 68, 81, 86

Salla, the Mahommedan Christmas, 192

Salt trade, Duala, 72

Salutations, 167 and $n$

Batta, 167

Bulala, 240-1

Hausa, 141-2

Kilba, 167

San Thomé: Cameroon Expedition, Boyd Alexander's diary of, 63 et seq., 81, 82, 84, 88 et seq.; peak of, ascent of, and collections on, 75-6 et seq.

"San Thomé," a puppy, 79, 103, 144, 184-5; illness and death of, 163-4, 166, 210, 214-17

Sanda, Shehu of Dikoa, 202, 207-9; Boyd Alexander's visit to, and to his relations, 209-10; troops of, reviewed, 205-7

Sanda, successor to Lowal, a scholar king, 160, 161

Sandjo, 128 et seq.

Sarbun, Sultan of Wadai, 287

Scents, Abechir market, 281

Scott, Captain, 275

Seita, 251-2

Senegal Hartebeest, 198, 213, 221, 234

Shari River, trade on, in French hands, 151

Shearwater (bird), 69

Shelley, Captain, 23

Shua, people of Bornu, 197, 219-21, 233, 236-8; Kotoko, 220-1 ; settled habits of, 237

Sleeping-sickness, alleged, on Fernando $\mathrm{Po}, 68$; on Prince's Island, 95-6

Snakes in camps, 200

Snares for guinea-fowl, 235

So people, giants, 213-14, 218-19, 221

Somervell, Mr., 14

Song, hills at, 164

Sopo, rail-head, Kamerun, 69

Spears, Shua, 236

Springett, John, 9, 23

"Squatting" (in cocoa), Fernando Po, 99

Stewart, - grave of, Maifoni, 177

Stone, - military commander, Yola, 152

Stormy Petrel, 73-4

Sunbirds and flowers, 224 
Sundy, roça of, Prince's Island, sleeping-sickness at, 96

Sunsets, in Africa, 138-9, 151

Swifts, Gajiro and Dikoa, 211

Swift's Place, Cranbrook, 5

TAксय, 142

Talbot, P. Amaury, 34, 41-2, 47-8, 54

Tama, Sultan of, 283

Taxation, German IV. Africa, 72, 73,132 ; at Ibi, 147

Taylor, Dr., Calabar, 66

Teeth-reddening, 176

Temple, Charles, and wife, 41

Thompson, Lieutenant, Maifoni, 176

Tobacco, trade goods in IV. Africa, 126

Trenchard, Colonel, 67

Tribal marks: Chibuk, 171; Kotoko of Afade, 222; Munshi, 143; on royal child at Dikoa, 210; ShuaKotoko women, 221

Tripoli, trade of, with Abechir, 279 284

Tsetse-fly on Prince's Island, 95-6

Tsetse-fly belts, 163-4, 233

Tubu race, 181, 209

Usuas UraJ, Rabeh's lieutenant, 228

VANGA MALABD, and the downfall of Bobo Amadu, 156 et seq.

Verre hills, 152-3, 161

Victoria, Cameroons, Bosd Alexander at, 69-70, 199-200 et seq.

Vogel, -, records of, at Abechir, destroyed, 273

von Raben, Lieutenant, resident, Kusseri, 224, 227

Vultures, speedy work of, 222

Wadar, Boyd Alexander's views on, cited, 43-4 ; fighting near, and at, 177,229 et seq. ; people of, 267-8, 274-5, 281, 286-7

Wady Choc, 273, 281

Wady Schau, 281
Wallace, Sir William, 163

Water, scant, en route to Abechir, 238-9

Weapons: disarmed tribes, 263 ; Munshi, 143; Wadaian, 267, 281

Webster, Thomas, R.A., 9-10

Welcome, and thanks in Hausa, 141-2

West Africa, products of (see also Palm Oil and Rubber), 66

West African natives, over-payment of, results, 127-8

Wharton, Mr., 21

White men, letters of, treated as $j u-j u$, 257 ; native methods of killing, 239

Wilcocks, General Sir James, and Boyd Alexander, 30, 37

Wilson, David, career of, 7

Womdiu, King of, and his Marragi subjects, 169-70

Women (see also Hairdressing and Tribal Marks), dances by, at Chibuk funeral, 170-1, at Dallwa, 175-6

Wood, Martin, writer, 39

Wooden sabres of disarmed tribes, 263

Wrestling at Dallwa, 173-5

Wukari, revisited, 143-4

IVuru, 163

Yamara, Boyd Alexander's visit to, 209-10

Yao, French post, Boyd Alexander at, $247,249-50$

Yei River, Boyd Alexander's voyage down, 35

Telua, 191

Yola, 151-3, 161; Boyd Alexander's visit to, 158 ; British administration in, 162; Emir of, fate of, $153 \mathrm{et} \mathrm{seq.}$

Yola Emirate, history of tribes comprised under, 159 et seq.

Zambesi and Kafuc Rivers, Boyd Alexander's bird-collections from, 29 Zubeir Pasha and Rabeh, $185 n$

Zubeiru, former Emir of Yola, 154, justice of, 161 


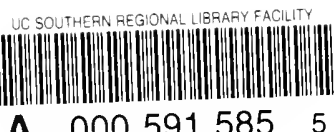


UNIVERSITY OF CALIFORNIA AT LOS ANGELES

THE UNIVERSITY LIBRARY

University of California

SOUTHERN REGIONAL LIBRARY FACILITY

405 Hilgard Avenue, Los Angeles, CA 90024-1388

Return this material to the library

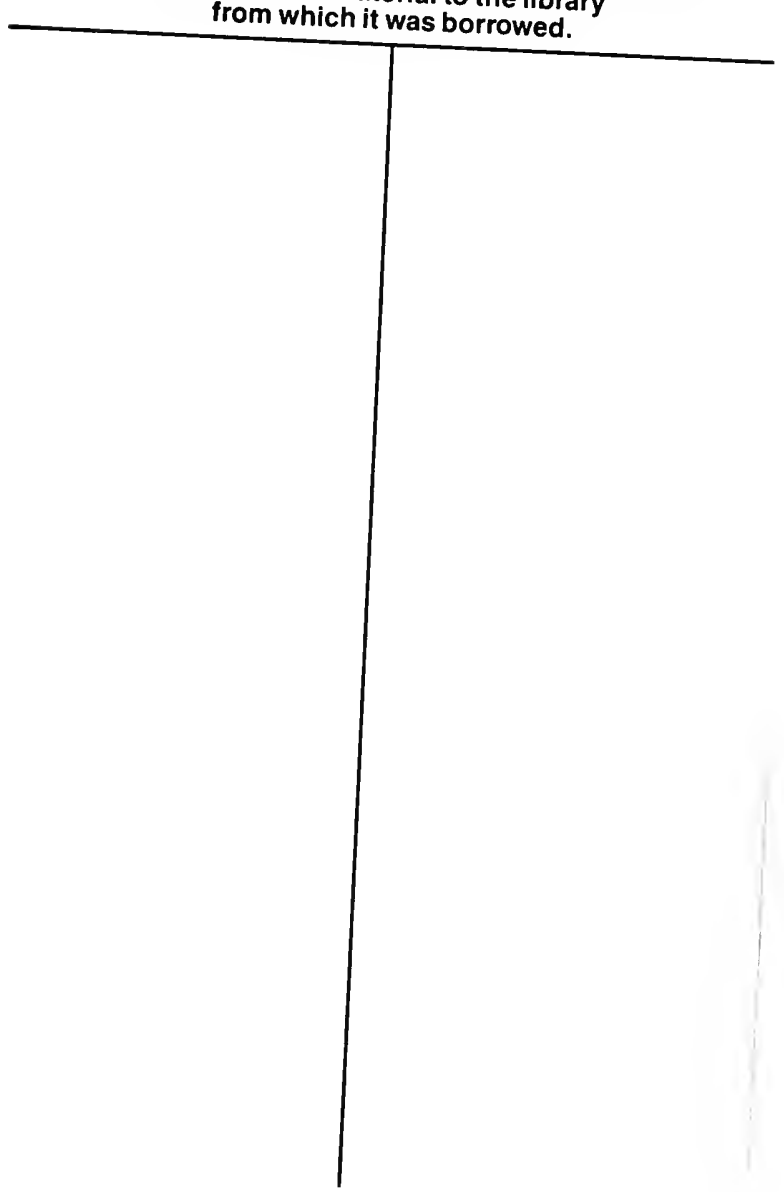

UNIVERSITY of CALIFORNIA AT

LOS ANGELES

LIBRARY 


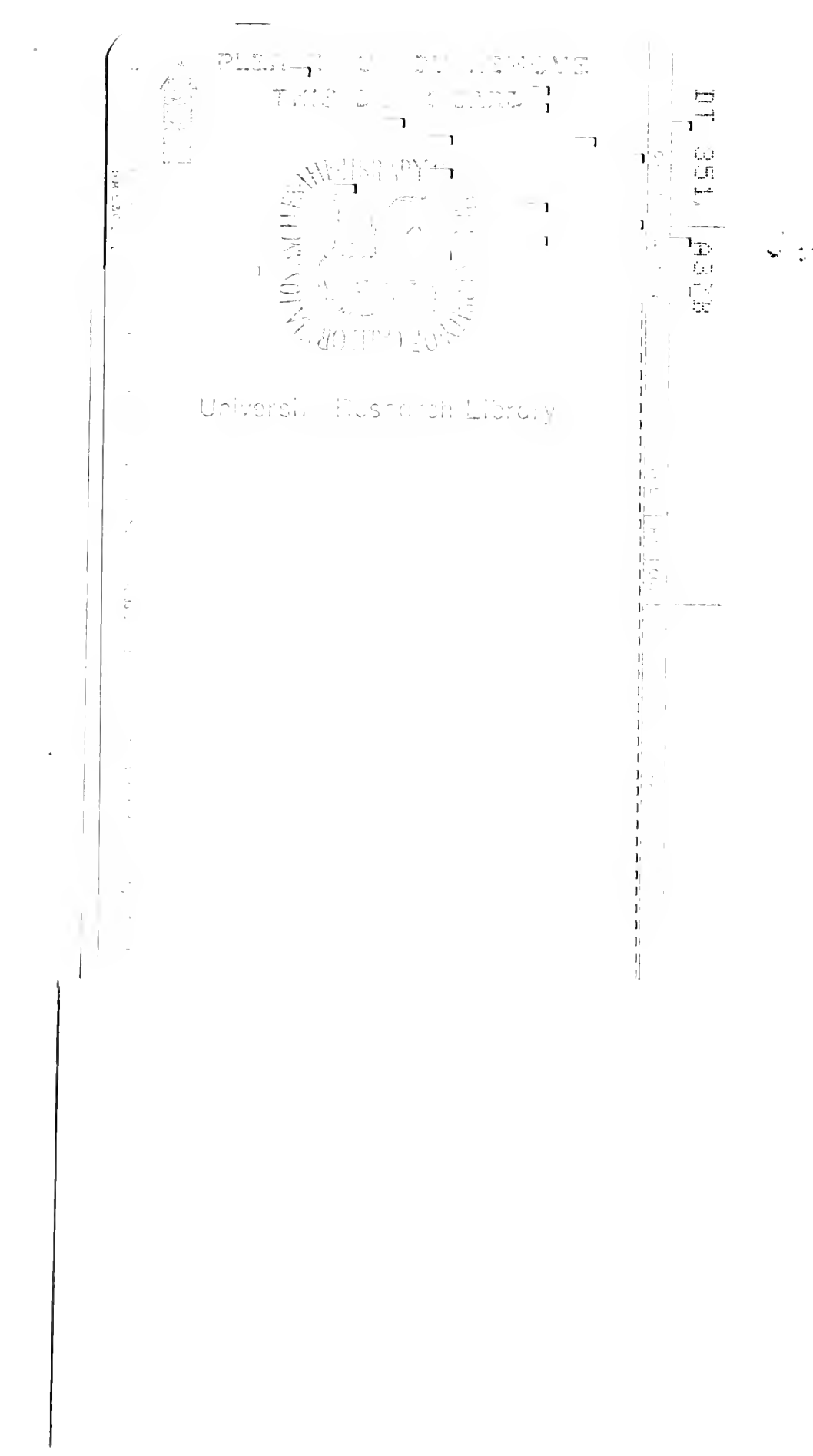


